\title{
Sistemas de gestão de saúde, meio ambiente e segurança do trabalho: \\ Enfoque e aplicação na indústria siderúrgica
}

\section{Domingos Dantas}

Dissertação apresentada ao Programa de Pós-Graduação em Saúde Pública da Faculdade de Saúde Pública da Universidade de São Paulo para obtenção do título de Mestre em Saúde Pública

Área de Concentração: Saúde Ambiental Orientador: Prof. Dr. Antonio Carlos Rossin

São Paulo

2005

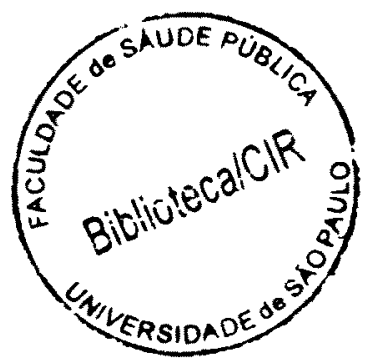


Dedicatória

À Célia, esposa e amiga, pelo incentivo, apoio e compreensão da importância deste meu trabalho acadêmico. 


\section{AGRADECIMENTOS}

Ao Prof. Dr. Antonio Carlos Rossin, pela orientação, clareza, objetividade e competência no aprimoramento deste trabalho.

Ao Prof. Dr. João Vicente de Assunção, pelo exemplo a ser seguido.

Ao Prof. Dr. Luís César de Souza Pinto, pela dedicação e empreendimento inovador na disciplina Obras Hidráulicas e Impactos Ambientais.

Ao Prof. Dr. Arlindo Philippi Junior, pelo apoio e orientação no início da pesquisa.

Ao Prof. Dr. Kokei Uehara, pelos ensinamentos transmitidos com sabedoria.

A Prof ${ }^{a}$ Dra. Maria Teresinha Dias de Andrade, pela contribuição no método da pesquisa.

Ao Dr. José Roberto Mendes da Silva, pelo apoio e consideração demonstrada para o desenvolvimento deste trabalho.

À Diretoria e Gerência das indústrias siderúrgicas que participaram da pesquisa de campo.

A Equipe do Centro de Informação e Referência (Biblioteca da Faculdade de Saúde Pública da USP) pelos excelentes serviços prestados à Comunidade Científica e a Sociedade.

A Elaine Palharim pela ajuda na digitação e revisão do texto.

Aos colegas Carlos Alberto Palomares Diaz e Antonio Carotenuto Neto pela análise crítica do questionário, roteiro da entrevista, planejamento e métodos da pesquisa. 


\section{RESUMO}

Dantas D. Sistemas de gestão de saúde, meio ambiente e segurança do trabalho: Enfoque e aplicação na indústria siderúrgica. São Paulo; 2005. [Dissertação de Mestrado - Faculdade de Saúde Pública da USP].

Introdução. Os modelos de sistemas de gestão evoluem com os avanços tecnológicos e necessidades das organizações no atendimento aos requisitos legais, exigências de mercado e expectativa das partes interessadas. Nesse contexto, os programas de qualidade, saúde, meio ambiente e segurança do trabalho dependem das operações de risco e complexidade do negócio. As abordagens apresentadas passam por métodos de padronização, gestão integrada e padrões de excelência que representam o estado da arte. Objetivos. Identificar quais são e analisar como os principais fatores de saúde, meio ambiente e segurança do trabalho afetam a eficiência operacional da indústria siderúrgica no Brasil. Identificar os principais benefícios e dificuldades da implantação e manutenção de sistemas de gestão de saúde, meio ambiente e segurança do trabalho. Propor indicadores de eco-eficiência operacional da indústria siderúrgica. Métodos. Utilização da pesquisa exploratória, pesquisa bibliográfica da literatura disponível sobre o assunto, de fonte direta, de questionário semi-aberto, de entrevistas com os gestores das indústrias siderúrgicas e de consultas nos bancos de dados de centros de pesquisa e de instituições ligadas à área da saúde, meio ambiente e segurança do trabalho. Resultados. $O$ envolvimento do alto executivo, a mudança da cultura organizacional, a conscientização, comprometimento da força de trabalho e a prevenção de impactos ambientais, riscos de acidentes e doenças ocupacionais são os principais fatores que afetam a eficiência operacional. Os dados obtidos na pesquisa de campo permitiram ampla discussão do tema e possibilitaram ao pesquisador fazer recomendações na busca da melhoria contínua. Conclusões. A indústria siderúrgica brasileira está inserida no mercado globalizado rumo à excelência na busca da responsabilidade social e dos princípios do desenvolvimento sustentável.

Descritores: Sistemas de Gestão. Eficiência Operacional. Indústria Siderúrgica. 


\section{SUMMARY}

\section{Dantas D. Health, environment and occupational safety management systems:} Focus and application on siderurgical industry. São Paulo; 2005. [Master's Degree Thesis - Faculdade de Saúde Pública da USP].

Introduction. The management systems models have been performing evolutions according to technology development, as well as, corporations' needs of complying with legal requirements, market demands and stakeholders expectations. In this context, quality, environmental, safety and occupational health programs depend on risk operations and business complexity. The presented approaches pass through standardization methods, integrated management and standards of excellency, which represent the state of art. Objectives. Identifying which are the main environmental, safety and occupational health factors, and analyzing the way they affect operational efficiency of siderurgical industry in Brazil. Identifying the main benefits and difficulties of introduction and maintenance of management systems. Proposing indicators of operational eco-efficiency on siderurgical industry. Method. Utilization of exploratory research, bibliographic research on the available literature, direct source, semi-open questionnaire, interview with siderurgical industries managers and consulting data bank of research centers and institutions connected with the areas of environmental, safety and occupational health. Results. The involvement of chief executive officers, the change of organizational culture, the awareness, commitment of work power and the prevention of environment impacts, accident risks and occupational diseases are the main factors that affect operational efficiency. The data, collected during the field research, make possible a wide discussion about the subject and allow the researcher to make recommendations towards the continuous improvement. Conclusions. Brazilian siderurgical industry is inserted in the global market towards the excellence, with social accountability, and it has been following the sustainable development principles.

Descriptors: Management Systems. Operational Efficience. Siderurgical Industry. 


\section{LISTA DE ABREVIATURAS E SIGLAS}

\begin{tabular}{|c|c|}
\hline ABIQUIM & : Associação Brasileira da Indústria Química \\
\hline ABNT & : Associação Brasileira de Normas Técnicas \\
\hline $\mathrm{ACV}$ & : Avaliação do Ciclo de Vida \\
\hline BEAC & $\begin{array}{l}\text { Board of Environmental Health } \varepsilon \text { Safety Auditor } \\
\text { Certifications. }\end{array}$ \\
\hline BNDES & : Banco Nacional de Desenvolvimento Econômico e Social \\
\hline BS & : British Standards \\
\hline BSI & : British Standards Institution \\
\hline BVS & : Biblioteca Virtual em Salud \\
\hline CAT & : Comunicação de Acidente do Trabalho \\
\hline $\mathrm{CB}$ & : Comitê Brasileiro \\
\hline $\mathrm{CCI}$ & : Câmara de Comércio Internacional \\
\hline CCPA & : Canadian Chemical Producers Association \\
\hline CEPAA & : Council on Economic Priorities Accreditation Agency \\
\hline CETESB & : Companhia Estadual de Tecnologia de Saneamento Ambiental \\
\hline CITES & $\begin{array}{l}\text { : Convenção _sobre o Comércio Internacional das Espécies de } \\
\text { Fauna e Flora Selvagens Ameaçadas de Extinção }\end{array}$ \\
\hline CLT & : Consolidação das Leis do Trabalho \\
\hline CONMETRO & : Conselho Nacional de Metrologia \\
\hline DIS & : Draft International Standard \\
\hline EAR & : Environmental Auditing Roundtable \\
\hline EIA & : Estudo de Impactos Ambientais \\
\hline EMAS & : Eco-Management and Audit Scheme \\
\hline EMS & : Environmental Management Systems \\
\hline FPNQ & : Fundação para o Prêmio Nacional da Qualidade \\
\hline FSP & : Faculdade de Saúde Pública \\
\hline GANA & : Grupo de Apoio à Normalização Ambiental \\
\hline $\mathrm{HS}(\mathrm{G})$ & : Health and Safety (Guide) \\
\hline HSE & : Health and Safety Executive \\
\hline
\end{tabular}


IBAMA : Instituto Brasileiro do Meio Ambiente e dos Recursos Naturais e Renováveis

IBGE : Instituto Brasileiro de Geografia e Estatística

ICHEME : Institution of Chemical Engineers

ICI

: Industrial Chemistry Institute

IEC

: International Eletrotechnical Commission

IIA

: Institute of Internal Auditors

ILO : International Labour Office

INMETRO : Instituto Nacional de Metrologia, Normalização e Qualidade Industrial

INSS : Instituto Nacional do Seguro Social

IPEA : Instituto de Pesquisa Econômica Aplicada

ISA : International Standard Association

ISO : International Standardization for Organization

ISRS : International Safety Rating System

LOS : Lei Orgânica de Saúde

MBC : Movimento Brasil Competitivo

MCT : Ministério da Ciência e Tecnologia

MEPF : Ministério Extraordinário de Política Fundiária

MIL-STD : Military Standard

MMA : Ministério do Meio Ambiente

MPAS : Ministério da Previdência e Assistência Social

MTE : Ministério do Trabalho e Emprego

NBR : Normas Brasileiras

NISAM : Núcleo de Informações de Saúde Ambiental da FSP/USP

OHSAS : : Occupational Health and Safety Assessment Series

OIT : Organização Internacional do Trabalho

OSHA : Occupational Safety and Health Administration

PBCO : Programa Brasileiro de Eliminação da Produção e do Consumo das Substâncias que destroem a Camada de Ozônio

PCMAT : Programa de Condições e Meio Ambiente de Trabalho

PCMSO : Programa de Controle Médico de Saúde Ocupacional 
PDCA : Plan, Do, Check, Action

PEERCENTER : Public Entity Environmental Management System Resource Center

PGR : Programa de Gerenciamento de Riscos

PIB : Produto Interno Bruto

PNAD : Pesquisa Nacional por Amostra de Domicílios

PNQ : Prêmio Nacional da Qualidade

PPEOB : : Programa de Prevenção da Exposição Ocupacional ao Benzeno

PPR : : Programa de Proteção Respiratória

PPRA : Programa de Prevenção de Riscos Ambientais

QSP : Centro de Qualidade, Segurança e Produtividade para o Brasil

e América Latina

RGE : Rio Grande Energia

RIMA : Relatório de Impacto ao Meio Ambiente

SA : Social Accountability

SAI : Social Accountability International

SCC : Safety Check list Contractors

SESMA : Segurança, Saúde e Meio Ambiente

SGA : Sistema de Gestão Ambiental

SGI : Sistemas de Gestão Integrada

SHE : Safety, Health and Environment

SIG : Sistemas Integrados de Gestão

SMS : Sistemas de Gestão de Saúde, Meio Ambiente e Segurança do

Trabalho

SSO : Segurança e Saúde Ocupacional

SST : Segurança e Saúde no Trabalho

SWOT : Strong, Weak, Opportunities, Threats

TQM : Total Quality Management

USP : : Universidade de São Paulo 


\section{LISTA DE FIGURAS, QUADROS E TABELAS}

\section{Figuras:}

Figura 1 : Medicina do Trabalho e Higiene Industrial ................................ 15

Figura 2 : Estrutura dos Critérios - Um Enfoque Sistêmico......................... 32

Figura 3 : Modelo de um Processo Baseado no Sistema de Gestão da Qualidade

Figura 4 : A ISO 14001 - Sistema de Gestão Ambiental como um Subconjunto da EMAS ............................................................ 39

Figura 5 : Modelo do Sistema de Gestão Ambiental................................... $\quad 40$

Figura 6 : Elementos do Sistema de Gestão de SST .................................... 41

Figura 7 : Gerenciamento de Segurança e Saúde com Base na Abordagem

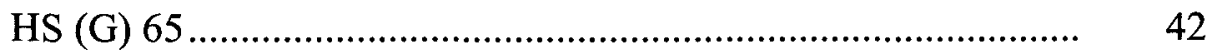

Figura 8 : Estrutura Típica do Sistema de Gestão ........................................ 43

Figura 9 : Sistema de Gestão ICI / SHE ..................................................... 45

Figura 10: Matriz de Programas de Saúde, Meio Ambiente e Segurança do Trabalho ................................................................................ 49

Figura 11: Ciclo PDCA do Sistema de Gestão Ambiental.......................... 59

Figura 12: Estrutura de Trabalho da ISO 14001 ...................................... 60

Figura 13: Planejamento e Implementação de SSO na Prática ..................... 63

Figura 14 : Planejamento e Implementação SMS ........................................... 67

Figura 15: O Triângulo da Inovação .............................................................. 69

Figura 16: A Evolução Normativa dos Sistemas de Gestão.......................... 73

Figura 17: Níveis de Auditoria ..................................................................... 75

Figura 18: Ilustração do Ciclo PDCA para a Gestão de um Programa de Auditoria ........................................................................... $\quad 80$

Figura 19: Conceito de Competência ......................................................... 81

Figura 20: Pirâmide de Frank Bird ............................................................... 89

Figura 21: Fases da ACV ........................................................................ 91

Figura 22: Dimensõès da ACV ............................................................... 92

Figura 23: Avaliação do Desempenho de Processos Industriais.................. 95

Figura 24: Hierarquia dos Indicadơres de Desempenho da Organização ..... 97 
Figura 25: Equipamento de Laminação Contínua....................................... 104

Figura 26: Representação Esquemática do Fluxo de Material no Processo de Laminação

Figura 27 : Esquematização da Seqüência de Decisões no Planejamento da Pesquisa

\section{Quadros:}

Quadro 1 : Evolução dos Modelos para a Gestão de Segurança e Saúde Ocupacional ......................................................................... 16

Quadro 2 : EMAS Comparado com a ISO 14001....................................... 35

Quadro 3 : Elementos Principais dos Modelos de Gestão ............................ 53

Quadro 4 : Diagnóstico Estratégico da Organização .................................... 65

Quadro 5 : Comparação entre OHSAS 18001 e ISO 14001 ...................... 82

Quadro 6 : Riscos Industriais.................................................................... 84

Quadro 7 : Níveis de Desempenho Operacional........................................ 100

Quadro 8 : Check List ABCD ................................................................. 101

Quadro 9 : Pontuação do Check List ABCD ............................................. 101

Quadro 10: Aspectos e Impactos de Saúde e Meio Ambiente nas Atividades da Laminação de Aços Não Planos ....................... 107

Quadro 11: Como os Fatores Positivos de SMS Afetam a Eficiência Operacional da Indústria Siderúrgica no Brasil ....................... 133

Quadro 12 : Como os fatores Negativos de SMS Afetam a Eficiência Operacional da Indústria Siderúrgica no Brasil..................... 134

Quadro 13 : Entrevista com os Gestores de SMS ....................................... 135

Quadro 14 : Nível de Significância.......................................................... 143

Quadro 15 : Principais Indicadores de SMS da Indústria Siderúrgica.......... 158

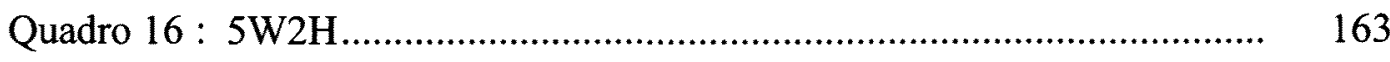




\section{Tabelas:}

Tabela 1 : Quantidade de Acidentes e Doenças do Trabalho Registrados no Brasil .......................................................................... 13

Tabela 2 : Produção de Laminados Não Planos ....................................... 116

Tabela 3 : Plano de Amostragem .......................................................... 116

Tabela 4 : Gestão Interna de Indicadores de Eco-eficiência...................... 170

Tabela 5 : Indicadores de Eco-eficiência das Indústrias Siderúrgicas no

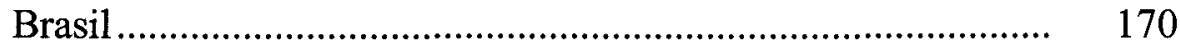

Tabela 6 : Indicadores de Eco-eficiência das Indústrias Siderúrgicas a Nível Mundial ...................................................................... 170 


\section{ÍNDICE}

Dedicatória

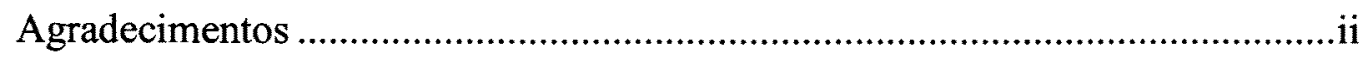

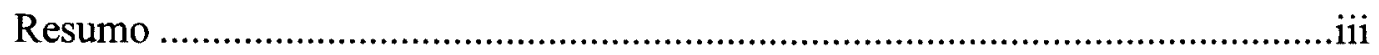

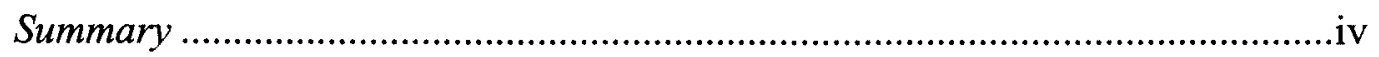

Lista de Abreviaturas e Siglas .......................................................................

Lista de Figuras, Quadros e Tabelas ..................................................................viii

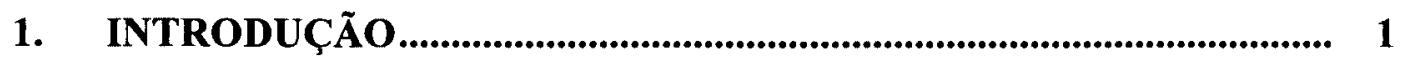

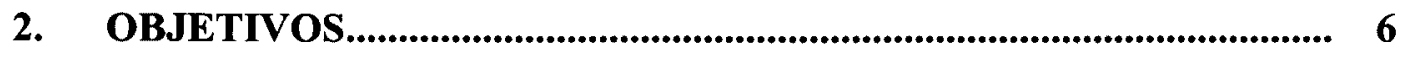

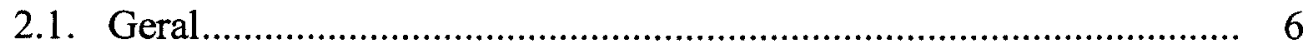

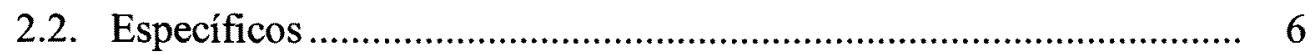

2.3. Delimitação da Pesquisa ................................................................... 6

2.4. Relevância da Pesquisa ................................................................. 6

3. REFERENCIAL TEÓRIC,O _........................................................... 8

3.1. Histórico da Segurança e Saúde Ocupacional ................................... 8

3.2. Gestão de Saúde e Segurança do Trabalho ........................................ 11

3.3. Programas de Implementação Compulsória ……………………….... 16

3.4. Recursos Naturais no Brasil - Situação e Comprometimento............. 18

3.5. Gestão Ambiental e Desenvolvimento ............................................ 29

3.6. Organismos de Normalização ........................................................ 54

3.7. Planejamento e Implementação de Sistemas de Gestão .................... 58

3.8. Sistemas Integrados de Gestão - SIG................................................ 68

3.9. Gerenciamento de Riscos......................................................... 83

3.10. Eficiência Operacional da Indústria................................................... 89 
4. PLANEJAMENTO E MÉTODOS DA PESQUISA ............................103

4.1. O Processo Industrial de Laminação de Aço Não Plano ....................103

4.2. Planejamento da Pesquisa ..........................................................110

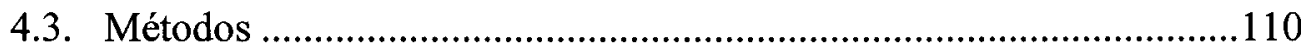

5. RESULTADOS E DISCUSSÕES...........................................................119

6. CONSIDERAÇÕES FINAIS ...............................................................160

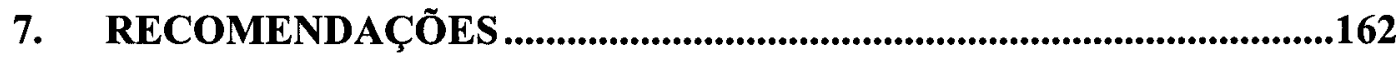

8. SUGESTÕES PARA TRABALHOS FUTUROS .................................173

9. REFERÊNCIAS BIBLIOGRÁFICAS..................................................174

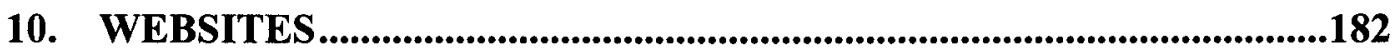

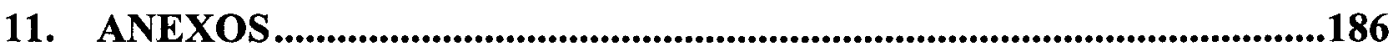

12. GLOSSÁRIO 


\section{INTRODUÇÃO}

(....) Os princípios do desenvolvimento sustentável envolvem o processo de integração dos critérios ambientais na prática econômica, a fim de garantir que os planos estratégicos das organizações satisfaçam a necessidade de crescimento e evolução contínuos e, ao mesmo tempo, conservem o "capital" da natureza para o futuro. Aplicar o princípio significa viver dentro da capacidade dos ecossistemas existentes. Isso exigirá mudanças em muitos aspectos da sociedade e comércio. Não se trata apenas da poluição do ar, depleção da camada de ozônio, conservação da água, uso de matéria prima e gestão de resíduo; trata-se também de um problema realmente internacional, que afeta as transações que atravessam fronteiras, comércio, finanças e agendas políticas. (Gilbert 1995, p. 2).

Os governos têm desenvolvido leis de proteção ambiental. Processos intergovernamentais estão com foco central nas questões de desenvolvimento e meio ambiente, os trabalhos com as partes interessadas e afetadas estão evoluindo, incluindo grupos ambientalistas, cientistas e empresários.

As indústrias têm respondido com códigos de práticas ambientais e um grande número de empresas publicam relatórios de impactos sobre o meio ambiente.

Neste contexto, temos a International Standardization for Organization - ISO 14001 como um sistema de gestão ambiental internacional de consenso e um novo paradigma entre a indústria e o setor público. É crucial para o acesso ao mercado global, o qual irá contribuir para o desenvolvimento industrial sustentável (Krut e Gleckman 1998).

Desenvolvimento sustentável deve, portanto, significar desenvolvimento social e econômico estável, equilibrado, com mecanismos de distribuição das riquezas geradas e com capacidade de considerar a fragilidade, a interdependência e as escalas de tempo próprias e específicas dos recursos naturais.

Viabilizar esse conceito na prática implica mudança de comportamento pessoal e social, além de transformações nos processos de produção e de consumo. Para tanto, faz-se necessário 'o desencadeamento de um processo de discussão e comprometimento de toda a sociedade. Essas características tornam, ainda hoje, o desenvolvimento sustentável um processo a ser ainda implementado (MMA 2002). 
Desenvolvimento sustentado é, pois, a meta principal a ser atingida em futuro não muito distante, possibilitando equilíbrio permanente no planeta (Tundisi 1998, p. 25).

Em 1987, a Comissão Mundial do Meio Ambiente e Desenvolvimento das Nações Unidas publicou o Relatório Brundland, apresentando um conceito de desenvolvimento sustentável - “... aquele desenvolvimento que atende às necessidades do presente sem comprometer as possibilidades de as gerações futuras atenderem às suas próprias" (Nosso Futuro Comum 1988, p. 46) - que, mais que um conceito, transmitia o desejo de mudança de paradigma para um estilo de desenvolvimento em que não se mostrasse excludente socialmente e danoso ao meio ambiente.

A Conferência das Nações Unidas sobre Meio Ambiente e Desenvolvimento, reunida no Rio de Janeiro de 3 a 14 de Junho de 1992, proclama:

\section{Princípio 1}

Os seres humanos estão no centro das preocupações com o desenvolvimento sustentável. Têm direito a uma vida saudável e produtiva, em harmonia com a natureza.

A política de saúde definida na Carta Constitucional de 1988 e Regulamentada na Lei Orgânica de Saúde (LOS 8080/1990) avançou na configuração de uma noção ampliada de saúde considerando como fatores determinantes e condicionantes da saúde, entre outros, a alimentação, a moradia, o saneamento básico, o meio ambiente, o trabalho, a renda, a educação, o transporte, o lazer e o acesso aos bens e serviços essenciais (Lucchese 2003).

Uma das grandes características que têm marcado o século XX é o crescente ritmo de inovações tecnológicas, com surgimento de sistemas altamente complexos de produção, como no caso das indústrias de processamento contínuo.

Tratar da questão das condições de trabalho, de saúde ou de vida dos trabalhadores é uma opção que procura resgatar a dimensão social e política das relações de trabalho, •bem como dialogar com as evidências encontradas no plano das práticas de gestão, recuperando também a sua dimensão subjetiva, que reflete 
escolhas de homens que dirigem e atuam sobre outros homens, que impõem riscos individuais e coletivos sobre a vida humana.

(...) As investigações de acidentes que vêm sendo empregadas nos EUA e no Canadá, bem como em países da Comunidade Européia, visam garantir que o conhecimento dos trabalhadores sobre o modo real de operação seja incorporado nas investigações, de forma que eles participem tanto das análises de acidentes quanto da discussão e implementação das estratégias de gerenciamento de riscos. (Bicudo e Tenório 1999).

A Occupational Health and Safety Assessment Series - OHSAS 18001 foi desenvolvida em resposta à urgente demanda, pelo reconhecimento de um padrão, no qual o Sistema de Gestão de Saúde e Segurança do Trabalho pudesse ser avaliado e certificado (OHSAS 2001).

Há uma interface muito importante entre as questões de meio ambiente e de saúde e segurança do trabalho. Os dois sistemas são indissociáveis, e, portanto, torna-se impossível falar de saúde e segurança do trabalho e não incluir o meio ambiente. Embora cada vez mais os assuntos de saúde, meio ambiente e segurança do trabalho estejam sendo agrupados como um único elemento, nem todas as indústrias estão entusiasmadas com a integração desses sistemas.

Segundo Wilkinson e Dale (1998), citado por Taralli (2001, p. 37), a integração das questões do meio ambiente e de saúde e segurança do trabalho é hoje vista como uma decisão de extrema importância, particularmente para aquelas indústrias que detêm operações de risco elevado.

Indústrias que desenvolvem sistemas integrados de saúde, meio ambiente e segurança do trabalho não vêem necessidade de um sistema separado para a Gestão Ambiental. O que as indústrias desejam é um sistema simples de gestão que proveja os procedimentos necessários e os mecanismos de controle para o direcionamento dos problemas que requerem ações dentro da organização. Sob os sistemas de saúde, meio ambiente e segurança do trabalho e outros a serem considerados e gerenciados coletivamente, a estratégia de gestão deve determinar os controles de operação e os recursos necessários. A maioria das indústrias com sistemas integrados, vêem o sistema de meio ambiente independente como um desperdício de recursos e duplicidade desnecessária de prátiças (Sharrat 1995, p. 72). 
O acirramento da concorrência torna as regras que regem o mercado mais severas e restritivas. Atualmente, algumas das exportações realizadas pelos segmentos considerados potencialmente poluidores, para os países onde há uma maior preocupação ecológica, estão condicionadas ao certificado de qualidade ambiental. Obter tal certificado exige investimentos em equipamentos e tecnologias antipoluentes, assim como a utilização de matérias primas e insumos em geral com padrões de qualidade ambiental satisfatórios. Isso exige envolvimento do fornecedor, criando-se, assim, a proteção ao meio ambiente em cadeia.

O Protocolo Verde é um acordo assinado entre o Instituto Brasileiro do Meio Ambiente e dos Recursos Naturais e Renováveis - IBAMA e o Banco Nacional de Desenvolvimento Econômico e Social - BNDES e alguns outros bancos governamentais, cujo objetivo é subsidiar a aquisição de tecnologias antipoluentes. Os recursos obtidos por meio deste programa exigem que a empresa elabore previamente um Estudo de Impactos Ambientais - EIA e, periodicamente, um Relatório de Impacto ao Meio Ambiente - RIMA, fato que auxilia a empresa no seu conhecimento, além de comprometê-la na melhoria do seu sistema operacional, tornando-o ambientalmente saudável.

A privatização de várias siderúrgicas, em 1992, exigiu investimentos de US\$ 320,7 milhões, o que representava cerca de $3 \%$ do Patrimônio Líquido das empresas envolvidas na implantação de controle das fontes de poluição.

As ações tomadas pelas empresas em prol da saúde, meio ambiente e segurança do trabalho poderiam ser divulgadas ao grande público com o intuito de estimular outras companhias a tomar decisões idênticas, bem como para demonstrar a responsabilidade e o comprometimento da empresa (Ribeiro 1998).

Muitas empresas ainda não possuem entendimento claro de como e por que os padrões são importantes. Entretanto, com a intensificação da competição global, os negócios são incrementados adotando uma nova disciplina denominada padronização estratégica. A gestão eficaz da padronização estratégica pode abrir novos mercados, aumentar as vendas, reduzir barreiras comerciais e melhorar a competitividade e o lucro da companhia."

Contrário à visão de que a padronização é um assunto exclusivamente técnico, é, antes de tudo, um problema crítico do negócio com implicações para o acesso de 
mercado, "anti-trust", responsabilidade civil pelo produto, política e proteção de patente, desenvolvimento de novos produtos, saúde e segurança do trabalho, o meio ambiente, mudanças na aquisição governamental e ainda na qualidade de vida.

A vida depende de muitos padrões que adotamos para garantia, tais como: ar e água; produtos que usamos; alimentos que comemos; como nos comunicamos, divertimos, trabalhamos, viajamos e conduzimos diariamente nossos negócios. A padronização está se tornando uma base para o comércio internacional e referência para a competição entre regiões, nações e corporações grandes e pequenas. $\mathrm{O}$ valor estratégico de padrões e seu desenvolvimento são fundamentais para melhorar o modo de vida no futuro.

"Há somente dois tipos de organização viável nos dias de hoje: Aquelas que adotam o processo global de padronização e aquelas que adotarão". (Morạn e Spanner 1996).

\section{O problema da Pesquisa}

Levando-se em consideração o cenário exposto, observa-se que podem existir várias razões que conduzem as empresas a implementar Sistemas de Gestão de Saúde, Meio Ambiente e Segurança do Trabalho (SMS). Elas estão visando a eficiência operacional para a conquista de novos mercados, competitividade global e melhoria da imagem corporativa. O problema desta pesquisa pode ser sintetizado da seguinte maneira:

Os Sistemas de Gestão de Saúde, Meio Ambiente e Segurança do Trabalho afetam a eficiência operacional da indústria. 


\section{OBJETIVOS}

\subsection{Geral}

Identificar quais são e analisar como os principais fatores de saúde, meio ambiente e segurança do trabalho afetam a eficiência operacional da indústria siderúrgica no Brasil.

\subsection{Específicos}

Os objetivos específicos são:

- Identificar os principais beneficios e dificuldades da implantação de sistemas de gestão de saúde, meio ambiente e segurança do trabalho.

- Identificar os principais benefícios e dificuldades da manutenção de sistemas de gestão de saúde, meio ambiente e segurança do trabalho.

- Propor indicadores de eco-eficiência operacional da indústria siderúrgica.

\subsection{Delimitação da Pesquisa*}

A pesquisa englobará o Sistema de Gestão Ambiental NBR ISO 14001:1996 e o Sistema de Gestão de Saúde e Segurança do trabalho OHSAS 18001:1999 com enfoque e aplicação no processo industrial de laminação de aços não planos.

\subsection{Relevância da Pesquisa}

2.4.1 Tema: (....) A relação entre a sociedade e as atividades industriais e de comércio vem aumentado sua importância de forma bastante intensa, afetando de maneira decisiva a vida das empresas. As questões de saúde, meio ambiente e segurança do trabalho, transcendem as fronteiras nacionais, tornando-se ponto vital nas relações de comércio internacional. Secretaria do Meio Ambiente (1998, p. 5). 
2.4.2 Área: (...) As usinas siderúrgicas pelo elevado grau de risco e complexidade dos processos industriais podem vir a gerar acidentes que envolvem a liberação de produtos tóxicos ou perigosos. Esses acidentes podem afetar a saúde humana causando mortandade ou mortalidade entre os expostos ou mesmo enfermidades retardadas. Podem afetar também as atividades empresariais e os sistemas que compõem o meio ambiente local (Pereira 1998).

2.4.3 Saúde Ambiental: A competitividade e a imagem das empresas serão os componentes que impulsionarão a busca pela excelência, as alianças estratégicas e a valorização das ações de empresas de capital aberto nas bolsas de negócios. Daí a importância dos sistemas de gestão como mecanismos de prevenção da saúde humana, de acidentes do trabalho, da poluição, do uso racional de recursos naturais, da responsabilidade social e principalmente do desenvolvimento sustentável. 


\section{REFERENCIAL TEÓRICO}

\subsection{Histórico da Segurança e Saúde Ocupacional}

O êxito de qualquer atividade empresarial é diretamente proporcional ao fato de se manter a sua peça fundamental - o trabalhador - em condições ótimas de saúde.

As atividades laborativas nasceram com o homem. Pela sua capacidade de raciocínio e pelo seu instinto gregário, o homem conseguiu, através da história, criar uma tecnologia que possibilite sua existência no planeta.

$\mathrm{Na}$ antigüidade, a quase totalidade dos trabalhos era desenvolvida manualmente uma prática que nós ainda encontramos em muitos trabalhos dos nossos dias.

Hipócrates, em seus escritos que datam de quatro séculos antes de Cristo, fez menção à existência de moléstias entre mineiros e metalúrgicos.

Plínio, o velho, que viveu antes do advento da Era Cristã, descreveu diversas moléstias do pulmão entre mineiros e envenenamento advindo do manuseio de compostos de enxofre e zinco.

Agrícola e Paracelso investigaram doenças ocupacionais nos séculos XV e XVI.

Georgius Agrícola, em 1556, publicou o livro "De Re Metallica", no qual foram estudados diversos problemas relacionados à extração e fundição do ouro e da prata. Essa obra discute os acidentes do trabalho e as doenças mais comuns entre os mineiros, dando destaque à chamada "asma dos mineiros". A descrição dos sintomas e a rápida evolução da doença parecem indicar, sem sombra de dúvidas, tratarem de silicose.

A primeira monografia sobre as relações entre ambiente de trabalho e doença foi de autoria de Paracelso em 1567. Ele fez numerosas observações relacionando métodos de trabalho ou manuseio de substâncias com doenças, como por exemplo, os principais sintomas de intoxicação pelo mercúrio.

Em 1700 era publicado, na Itália, um livro que iria ter notável repercussão em todo o mundo. Tratava-se da obra "De Morbis Artificum Diatriba" de autoria do médico Bernardino Ramazzini, sendo, por esse motivo, cognonimado de o "Pai da Medicina do Trabalho". Nessa importante obra, verdadeiro monumento da saúde ocupacional, é descrita cerca de 100 profissões diversas e os riscos específicos de 
cada uma. Um fato importante é que muitas dessas descrições são baseadas nas próprias observações clínicas do autor, nunca se esquecendo de perguntar ao seu paciente: “Qual a sua ocupação?”.

Devido à escassez de mão de obra qualificada para a produção artesanal, o gênio inventivo do ser humano encontrou na mecanização a solução do problema.

Entre 1760 e 1830, ocorreu na Inglaterra a Revolução Industrial, marco inicial da moderna industrialização, que teve a sua origem com o aparecimento da primeira máquina de fiar.

Até o advento das primeiras máquinas de fiação e tecelagem, o artesão fora o dono dos seus meios de produção. Essa situação foi se modificando, pois o custo elevado das máquinas não permitiu ao próprio artífice possuí-las. Assim os capitalistas, antevendo as possibilidades econômicas dos altos níveis de produção, decidiram adquiri-las e empregar pessoas para fazê-las funcionar. Surgiram assim, as primeiras fábricas de tecidos e, com elas, o capital e o trabalho.

A introdução da máquina a vapor mudou integralmente a indústria, que não mais dependia de cursos d'água, veio para as grandes cidades, onde era abundante a mãode-obra.

A improvisação das fábricas e a mão-de-obra constituída não só de homens, mas também de mulheres e crianças, sem quaisquer restrições quanto ao estado de saúde e desenvolvimento físico, passaram a ser uma constante.

O trabalho em máquinas sem proteção, o trabalho executado em ambientes fechados onde a ventilação era precária e o nível de ruído atingia limites altíssimos. Além disso, a inexistência de limites de horas de trabalho trouxe como conseqüência elevados índices de acidentes e de moléstias profissionais (Michel 2001).

Assim, surgiram na Inglaterra:

$1802 \Rightarrow$ a "Lei de Saúde e Moral dos Aprendizes" que proibia o trabalho para menores de 9 anos e o trabalho noturno. Estabelecia o limite de 12 horas para uma jornada de trabalho e tornava obrigatória a ventilação das fábricas, entre outros pontos;

$1833 \Rightarrow$ O "Factory Act", considerada a primeira legislação realmente eficiente no campo da proteção do trabalhador, que proibia o trabalho noturno aos menores de 18 anos e restringia as horas de trabalho desses a 12 por dia e 69 por semana; 
definia que as fábricas precisavam ter escolas, as quais deveriam ser freqüentadas por todos os trabalhadores menores de 13 anos; além de acompanhamento médico para atestar que o desenvolvimento físico da criança correspondia à sua idade cronológica.

Com a expansão da Revolução Industrial para o resto da Europa, a Alemanha ditou normas nesse mesmo sentido, em 1839, seguida pela França em 1841. A Espanha se incorpora a essa linha em 1873, proibindo o emprego de crianças com menos de 10 anos.

Nos Estados Unidos, apesar da industrialização ter-se desenvolvido de forma acentuada a partir da segunda metade do século XIX, só no início do século XX, a partir da legislação sobre indenizações em casos de acidentes do trabalho, é que surgiram os primeiros serviços médicos de empresas, com o objetivo de reduzir o custo das referidas indenizações. Nos últimos 40 anos, tal programa foi se ampliando, passando a incluir problemas mórbidos não ocupacionais de menor importância. Hoje, o princípio da manutenção da saúde, ou da prevenção das doenças de qualquer natureza foi incorporado aos objetivos da grande maioria dos serviços médicos industriais americanos, com excelentes resultados.

No Brasil, os serviços médicos de empresa são de existência relativamente recente, tendo sido criados por livre iniciativa dos empregadores. Esses serviços possuíam, até bem pouco tempo, um sentido eminentemente curativo e assistencial, não tendo ainda, de forma geral, o caráter preventivo estabelecido pela recomendação $\mathrm{n}^{\circ} 112$ da Organização Internacional do Trabalho - OIT. No entanto, em junho de 1972, integrando o Plano de Valorização do Trabalhador, o Governo Federal baixou a Portaria $n^{\circ} 3.237$, tornando obrigatória a existência, não somente de serviços médicos, mas também de serviços de higiene e segurança em todas as empresa com mais de 100 empregados.

Em função da grande quantidade de graves acidentes ocorridos nas décadas de $50,60,70$ e 80, especialmente nas indústrias químicas, petroquímicas e de petróleo, acentuou-se a necessidade de instrumentos mais eficazes para garantir a segurança dos funcionários das organizações e das partes interessadas afetadas. Nesse sentido, intensificou-se o uso de ferramentas de gestão na área de segurança, entre os quais se incluem as técnicas de análise de riscos, a elaboração de planos de ação de 
emergência, elaboração de programas de prevenção de riscos e a realização de auditorias de segurança (Bureau Veritas 2003).

\subsection{Gestão de Saúde e Segurança do Trabalho}

Estatísticas oficiais de acidentes e doenças relacionadas com o trabalho não apresentam a extensão plena da dor e sofrimento que cada evento traz para as vítimas, suas famílias, colegas e amigos. Além do custo humano, os acidentes e doenças do trabalhador impõem custos financeiros aos indivíduos, empregadores e à sociedade em geral.

Estudos do Health and Safety Executive indicam que o custo global para os empregadores decorrentes de acidentes do trabalho com ferimentos pessoais, com doenças relacionadas com o trabalho e acidentes evitáveis não causadores de ferimentos é estimado como equivalente a $5 \%$ a $10 \%$ dos lucros brutos de todas as empresas do Reino Unido.

Há, portanto, sólidas razões econômicas para reduzir os acidentes e doenças relacionadas com o trabalho, assim como motivos éticos e legais. Além de reduzir os custos, o gerenciamento eficaz dos sistemas de gestão de saúde e segurança do trabalho promove a eficiência dos negócios (BS 8800 1996, p. 8).

A OHSAS 18001 define o sistema de gestão de saúde e segurança do trabalho como:

- Parte do sistema de gestão global que facilita o gerenciamento dos riscos, associados aos negócios da organização. Isto inclui a estrutura organizacional, atividades de planejamento, responsabilidades, práticas, procedimentos, processos e recursos para desenvolver, implementar, atingir, analisar criticamente e manter a política de segurança e saúde do trabalhador.

Define-se como acidente do trabalho aquele que ocorre pelo exercício do trabalho a serviço da empresa, provocando lesão corporal ou perturbação funcional, permanente ou temporária, que cause a morte, a perda ou a redução da capacidade para o trabalho. 
São considerados acidentes do trabalho a doença profissional e a doença do trabalho. Equiparam-se também ao acidente do trabalho: o acidente ligado ao trabalho que, embora não tenha sido a causa única, haja contribuído diretamente para a ocorrência da lesão; certos acidentes sofridos no local e horário de trabalho; a doença proveniente de contaminação acidental do empregado no exercício de sua atividade; e o acidente sofrido a serviço da empresa ou no trajeto entre a residência $\mathrm{e}$ o local de trabalho e vice-versa (MPAS 2002).

\subsubsection{Os Números de Acidentes e Doenças do Trabalho no Brasil}

As ocorrências de acidentes e doenças do trabalho são comunicadas ao Instituto Nacional do Seguro Social - INSS pelo documento de registro oficial de acidentes do trabalho no Brasil, denominado Comunicação de Acidente do Trabalho - CAT.

No entanto é de conhecimento público que existe sub-registro de acidentes do trabalho, principalmente quando é acidente não grave e o trabalhador não necessita afastar-se de suas atividades profissionais. Por outro lado, à medida que a gravidade aumenta o sub-registro diminui, especialmente nos casos fatais (MPAS 2002).

A Tabela 1 apresenta o registro oficial da quantidade de acidentes e doenças do trabalho nos diversos setores de atividade econômica no Brasil. 
Tabela 1 - Quantidade de Acidentes e Doenças do Trabalho Registrados no Brasil

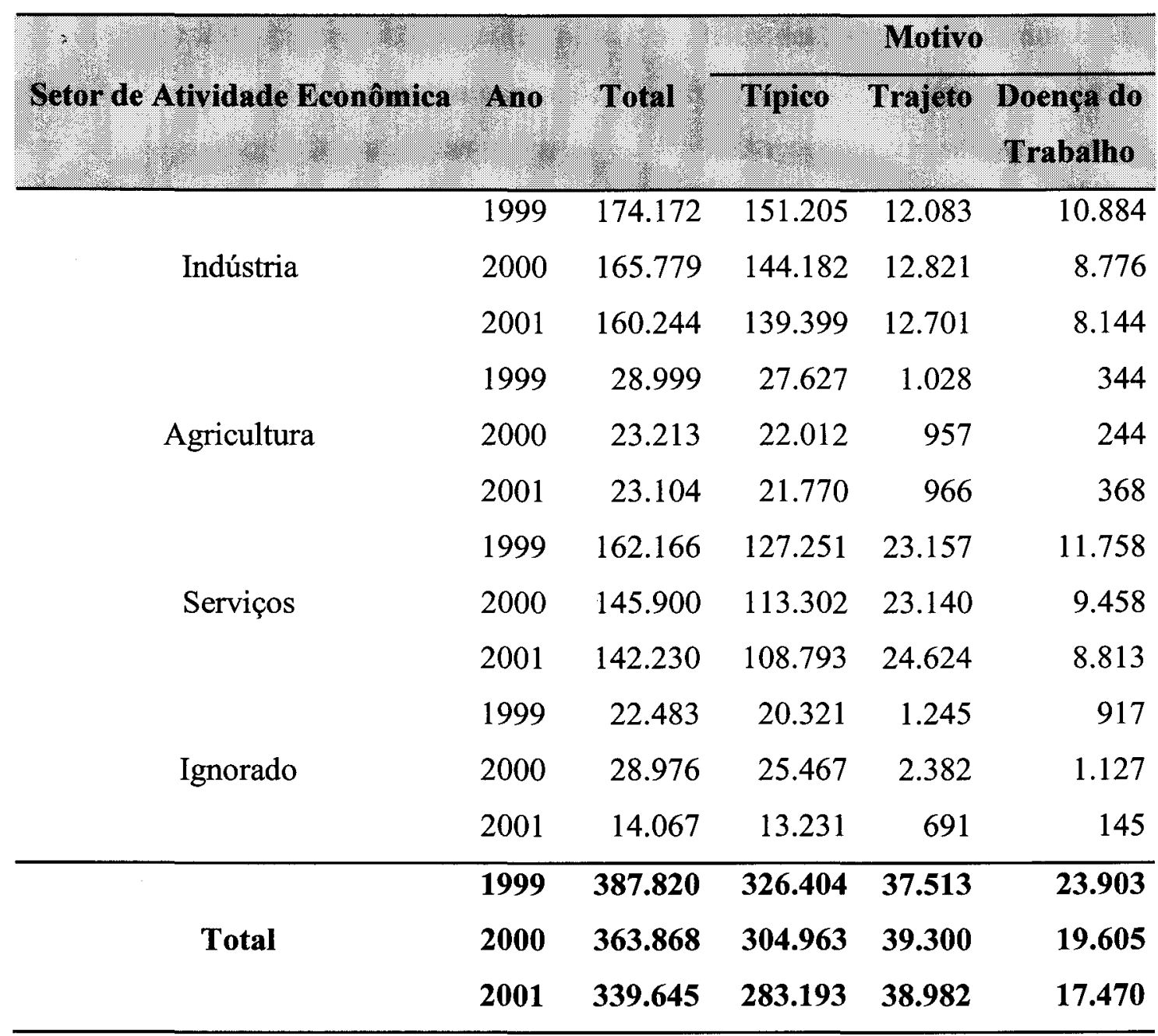

Fonte: Dataprev (CAT, 2002)

O quantitativo de registros de acidentes do trabalho apresentou decréscimo da ordem de 6,18\% de 1999 para 2000, e de 6,66\% de 2000 para 2001. Essa queda é marcada pelos acidentes registrados com motivos típico e doença do trabalho. Ao analisarmos os registros de acidentes do trabalho por setor de atividade econômica, verificamos que, dos 339.645 acidentes registrados em 2001, 6,8\% correspondem à agricultura, $47,18 \%$ à indústria, $41,87 \%$ a serviços e $4,14 \%$ a setor de atividade econômica ignorado.

Embora o direito do trabalhador à redução dos riscos inerentes ao trabalho esteja previsto na Constituição Federal, a situação no ambiente de trabalho, por mais que 
tenha melhorado nos últimos anos, ainda não é adequada, pois é preocupante o número de acidentes de trabalho registrados no Brasil.

A despesa relacionada ao pagamento de benefícios decorrentes de acidentes de trabalho no ano de 2000 alcançou a cifra de $\mathrm{R} \$ 1.612 .136 .000,00$. Considerando que esse é o custo direto dos acidentes e que as estimativas mais conservadoras do custo indireto dos acidentes de trabalho correspondem a quatro vezes o custo direto, então o custo total anual para a economia brasileira, devido aos acidentes de trabalho, foi de aproximadamente 7 bilhões de reais (Aquino e Philippi 2002).

Mesmo que nos países industrializados tenha-se observado um claro decréscimo na ocorrência de acidentes graves, como resultado da promoção de melhorias no local de trabalho e de mudanças na organização do trabalho, verifica-se que a forma de envolvimento com o trabalho está gerando novos riscos ocupacionais, incluindo problemas musculares, estresse, distúrbios mentais, reações alérgicas e problemas causados por exposição a agentes cancerígenos e perigosos (ILO 2001).

Portanto, são necessários investimentos e capacitação profissional nas principais ciências dedicadas à prevenção dos riscos ocupacionais:

Higiene ocupacional: Prevenção de riscos ambientais e doenças ocupacionais. Segurança do trabalho: Prevenção e controle de riscos operacionais e acidentes do trabalho.

Medicina do trabalho: Controle e vigilância de alterações de saúde.

Ergonomia: Organização metódica do trabalho em função do fim proposto e das relações entre o homem e a máquina. É a adaptação do trabalho ao homem ou, seja, das condições de trabalho ao homem.

A Figura 1 apresenta a relação entre a medicina do trabalho e a higiene industrial.

O Quadro 1 apresenta o uso de ferramentas para gestão de segurança e saúde ocupacional. 


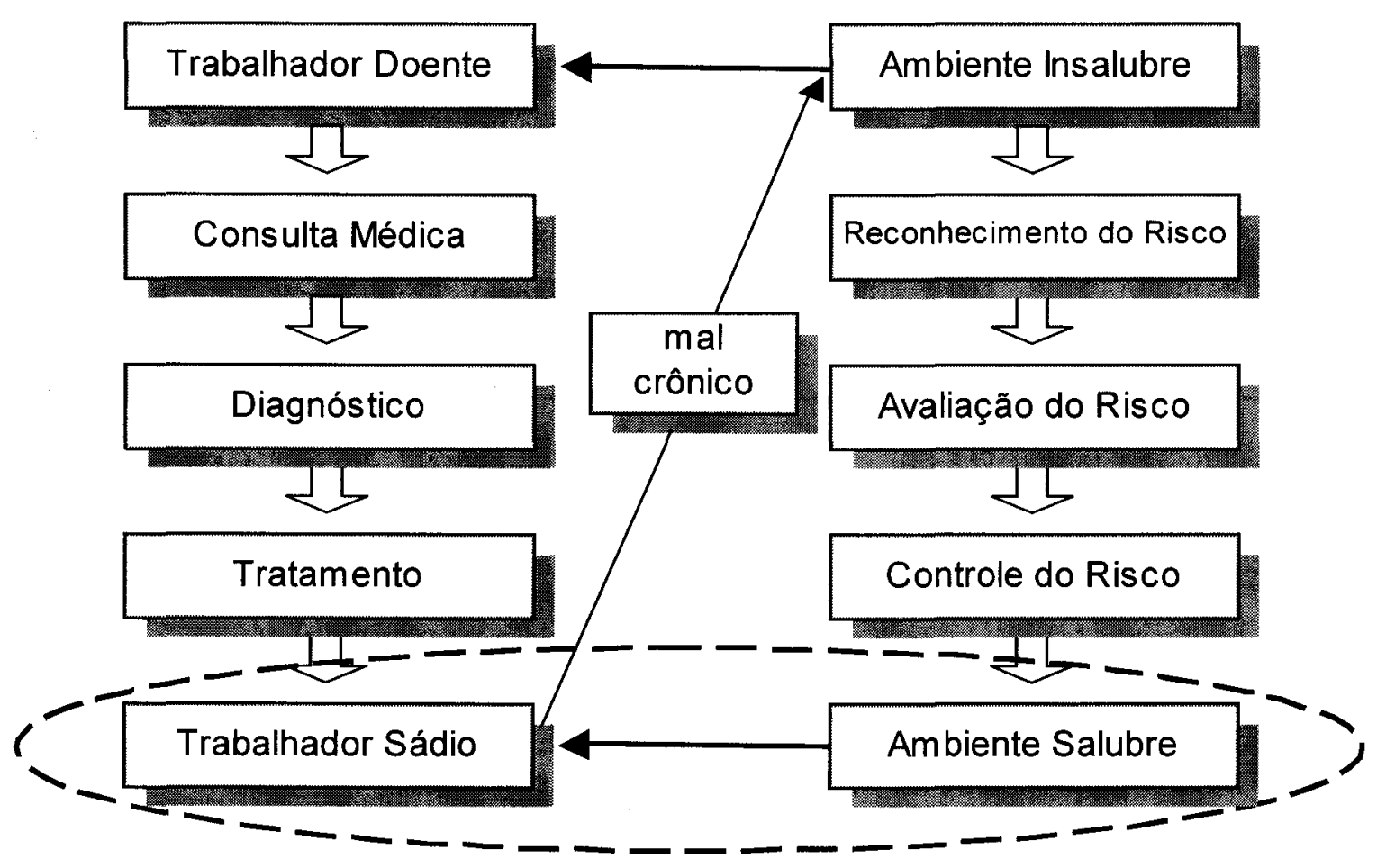

Figura 1 - Medicina do Trabalho e Higiene Industrial

Fonte: Bureau Veritas (2003, p. 11) 
Quadro 1 - Evolução dos Modelos para Gestão de Segurança e Saúde Ocupacional

\begin{tabular}{|c|c|}
\hline Evolução & Modelo Normativo \\
\hline 1980 & $\begin{array}{l}\text { ISRS - International Safety Rating System } \\
\text { (Petróleo e Petroquímica) }\end{array}$ \\
\hline 1986 & Atuação responsável \\
\hline 1991 & $\begin{array}{l}\text { SCC - Safety Check List Contractors } \\
\text { (Holanda, para contratados da indústria de Petróleo / } \\
\text { Petroquímica) }\end{array}$ \\
\hline Maio/96 & Publicada a BS 8800 (BSI, London) \\
\hline Setembro/96 & $\begin{array}{l}\text { A ISO desaprova a criação de um Grupo de Trabalho para uma } \\
\text { norma de gerenciamento de segurança e saúde ocupacional }\end{array}$ \\
\hline 1997 & $\begin{array}{l}\text { Normas nacionais para sistema de gestão de SSO } \\
\text { (Austrália, Nova Zelândia e Dinamarca) }\end{array}$ \\
\hline 1997 & $\begin{array}{l}\text { SCC - Safety Check List Contractors } \\
\text { (Ampliada para vários países e setores) }\end{array}$ \\
\hline 1998 & $\begin{array}{l}\text { Discussão na Europa para a certificação de sistema de gestão com } \\
\text { base na BS } 8800\end{array}$ \\
\hline Novembro/98 & $\begin{array}{l}\text { BSI + organismos de certificação + organismos nacional de } \\
\text { normalização criam uma norma unificada de SSO }\end{array}$ \\
\hline Início/99 & A ISO ratifica a decisão de Setembro/96 \\
\hline Fevereiro/99 & Publicada a Norma OHSAS 18001 \\
\hline
\end{tabular}

Fonte: Bureau Veritas (2003, p. 8)

\subsection{Programas de Implementação Compulsória}

As normas regulamentadoras de segurança e saúde no trabalho (MTE 2001) aprovadas através da Portaria do Ministério do Trabalho $\mathrm{n}^{\circ} 3.214$ de 08 de Junho de 1978 sofreram diversas alterações ao longo dos anos. Atualmente, existem trinta (30) normas regulamentadoras, sendo que algumas estabelecem a obrigatoriedade da elaboração e implementação de programas na área de segurança e saúde no trabalho, onde couber: 
- Programa de Controle Médico de Saúde Ocupacional (PCMSO) publicado na Norma Regulamentadora NR 7 em Dezembro de 1994.

- Programa de Prevenção de Riscos Ambientais (PPRA) publicado na Norma Regulamentadora - NR 9 em Dezembro de 1994.

- Programa de Prevenção da Exposição Ocupacional ao Benzeno (PPEOB) publicado no Anexo 13A da NR 15 em Dezembro de 1995.

- Programa de Condições e Meio Ambiente de Trabalho na Indústria da Construção (PCMAT) publicado na NR 18 em Julho de 1995.

- Programa de Gerenciamento de Riscos na Mineração (PGR) publicado na NR 22 em Dezembro de 1999.

- Programa de Proteção Respiratória (PPR) estabelecido pela Instrução Normativa $\mathrm{n}^{\circ} 1$ do Ministério do Trabalho de 11 de Abril de 1994, que tem por objetivo disciplinar a seleção e uso de equipamentos de proteção respiratória.

Considerando que a legislação brasileira sobre segurança e saúde no trabalho disciplina diversas ações na forma de programas, cabe distinguir o que é referido costumeiramente na legislação como programa e as novas abordagens de sistemas de gestão.

Usualmente, um programa opera de forma singular, vertical e baseado nas regras tradicionais de comando - controle. Os programas normalmente não contêm um ciclo de retro-alimentação ou mecanismos de avaliação, segundo o qual podem ser ajustados ou modificados em diversas circunstâncias. Por outro lado, a abordagem de sistema amplia a perspectiva de melhor integrar os programas individuais com as operações de negócio da organização, e, ao mesmo tempo, propicia melhor entendimento de como um programa pode afetar outros.

Além disso, a abordagem de sistema focaliza o princípio da melhoria contínua, uma vez que há um claro ciclo de retro-alimentação e mecanismos de avaliação do sistema (Silva 2002). 


\subsection{Recursos Naturais no Brasil - Situação e Comprometimento}

\subsubsection{Solo}

É evidente a ocorrência de processos de uso inadequado do recurso solo, resultando em degradação em vários níveis e graus. Nesses processos, incluem-se, principalmente: acidificação, salinização, erosão e desertificação. A extensão dessas áreas degradadas é de difícil dimensionamento, mas é reconhecidamente expressiva. Segundo dados do Instituto de Pesquisa Econômica Aplicada - IPEA (1997), as perdas ambientais associadas ao recurso solo para uso agrícola e florestal, causadas por processos de erosão, são estimadas em 5,9 bilhões de dólares ou 1,4\% do Produto Interno Bruto - PIB brasileiro.

\section{(....) O recurso solo tem sido afetado, também, por:}

- Uso inadequado de pesticida e defensivos agrícolas que causa poluição das águas, devido ao arrastamento desses materiais pela água da chuva para o curso d'água.

- Contaminação dos alimentos produzidos incorporando os agrotóxicos nas plantas, animais e no próprio homem.

- Atividades não-agrícolas, incluindo-se a mineração, as obras de infraestrutura, os assentamentos urbanos e industriais, as áreas de recreação, entre outras (MMA 2002).

\subsubsection{Recursos Hídricos}

São inúmeros os setores que utilizam os recursos hídricos como insumo básico para suas atividades. Há, desse modo, necessidade de que os critérios e normas setoriais sejam consistentes com a legislação específica, de forma a permitir o disciplinamento desses diferentes usos. Entre eles, destacam-se o saneamento, a irrigação, a produção de hidroeletricidade, o transporte hidroviário, o uso industrial da água, a pesca e a aqüicultura.

Os conflitos de interesse com relação ao uso da água, representados pelo setor hidrelétrico, pelos complexos industriais, pelas necessidades de abastecimento 
urbano, irrigação e adensamento urbano industrial, evidenciam a necessidade de articulação interinstitucional e a adoção de uma política de gestão integrada de recursos hídricos.

As secas são fenômenos freqüentes no país e acarretam graves problemas sociais e econômicos, não só onde o processo é mais intenso, como no Polígono das Secas, como também nas regiões Centro-Oeste, Sul e Sudeste, onde longos períodos de estiagem podem causar sérios efeitos sócio-econômicos. Muitas vezes a atenuação do problema da seca passa de fato pela mobilização de novas reservas de água, com a construção de novos açudes ou a implementação de transposição de bacias.

Nesse sentido, a exploração de águas subterrâneas vem, atualmente, registrando um expressivo incremento. Vários núcleos urbanos abastecem-se de água subterrânea, de forma exclusiva ou complementar no Brasil. Indústrias, propriedades rurais, escolas, hospitais e outros estabelecimentos utilizam água de poços rasos e artesianos.

As inundações acarretam graves problemas sociais e econômicos. É necessário fazer distinção, no entanto, entre as enchentes fluviais, que são processos naturais pouco influenciados pelas ações do homem, e as inundações urbanas, cujos efeitos são muitas vezes trágicos e desastrosos em face do uso inadequado do solo nas áreas urbanas e da adoção de técnicas pouco eficientes de drenagem urbana. Quase todas as grandes cidades brasileiras sofrem sérias conseqüências decorrentes das várias inundações anuais.

O quadro social é desfavorável, já que mais de 11 milhões de pessoas que residem em cidades ainda não têm acesso à água por meio de rede canalizada. Atualmente, o principal déficit do setor saneamento concentra-se no esgoto sanitário. Segundo dados da Pesquisa Nacional por Amostra de Domicílios - PNAD (1996), $48,9 \%$ do esgoto produzido no Brasil é coletado em rede pública, sendo que apenas $32 \%$ desse esgoto é tratado. Isso representa menos de $16 \%$ do total do esgoto produzido.

Outro aspecto a ser destacado refere-se ao desperdício de água nos sistemas públicos de abastecimento. Estima-se que no Brasil esse desperdício possa chegar a $45 \%$ do volume ofertado à população, o que corresponde à cerca de 4,68 bilhões de $\mathrm{m}^{3}$ de água produzidos, no país, por ano. 
A irrigação é o uso que mais consome água. Estima-se ser da ordem de $70 \%$ a parcela da irrigação do total de água. O uso intensivo da irrigação vem acarretando, em algumas regiões do Brasil, graves conflitos, não só envolvendo a irrigação com outros usos (abastecimento público, por exemplo), como também propiciando sérias disputas de irrigantes entre si. Muitos desses conflitos poderiam ser evitados se fossem adotadas técnicas de irrigação mais eficientes quanto ao uso da água (MMA 2002).

\subsubsection{Recursos Florestais}

A ocupação das terras florestadas pelo homem - seja para uso dos recursos florestais ou para sua transformação em áreas de produção de alimentos - tem sido característica marcante do crescimento econômico do país.

O desmatamento resulta de fatores econômicos e sociais e da fragilidade institucional de fazer cumprir a norma legal. Entre esses, destacam-se: a distribuição fundiária e os baixos níveis de produtividade agrícola nas áreas de fronteira; a distribuição da renda nacional, também altamente concentrada, ocasionando uma imensa oferta de mão-de-obra de baixa renda disposta a encontrar trabalho em áreas de fronteira de ocupação; um sistema fiscal e creditício para as atividades agrícolas que desconsidera as características agroecológicas do solo e o emprego de práticas de manejo sustentável; a titularidade da terra pautada no uso, isto é, baseada na área convertida para agropecuária, e, portanto, permitindo a legalização do desmatamento; o alto valor da madeira nas áreas de fronteira que faz com que as atividades madeireiras desempenhem um papel importante no financiamento do desmatamento; os programas setoriais de desenvolvimento que, muitas vezes, estimulam a ação antrópica não-sustentável sobre os recursos florestais e os programas de reforma agrária desenvolvidos pelo Ministério Extraordinário de Política Fundiária - MEPF, que têm contribuído significativamente para 0 desmatamento de áreas florestadas.

A atividade florestal concorre em espaço físico com as atividades agropecuárias, e, em virtude das características de longo prazo e da baixa rentabilidade dessa atividade, as florestas têm sido convertidas em áreas de agricultura e pecuária. 
A área de desmatamento na Amazônia está entre 11 e 13\% da área total original. Estimadamente, cerca de $50 \%$ da cobertura original de cerrado está convertida em pastos, plantações de soja ou formas degradadas de solos abandonados. Outro problema na região Centro-Oeste é a extração não-sustentável de madeira do bioma cerrado para a produção do carvão vegetal. Os incêndios agravam a destruição da floresta (MMA 2002).

\subsubsection{Biodiversidade}

O Brasil é considerado um dos países detentores de megadiversidade biológica. Abriga cerca de $10 \%$ a $20 \%$ do número de espécies conhecidas pela ciência, principalmente nas suas extensas florestas tropicais úmidas, que, por sua vez, representam cerca de $30 \%$ das florestas desse tipo no mundo (MMA, Relatório nacional sobre a biodiversidade, 1998).

A questão central da concentração da biodiversidade e seu uso sustentável estão no desafio de implementar meios de gestão ou manejo que garantam a continuidade de espécies, formas genéticas e ecossistemas. A realidade tem mostrado que, quando os meios de ação são bem manejados, podem, de fato, servir como ferramenta para a conservação da natureza.

$\mathrm{O}$ impacto que tem sofrido os biomas brasileiros decorre do processo de ocupação antrópica dos espaços nacionais, onde práticas econômicas e sociais arcaicas se têm perpetuado. Muitas dessas práticas incluem a premissa de que os recursos naturais são inesgotáveis e que, portanto, não se justificam iniciativas de preservação ou conservação cujo efeito imediato resulta em aumento dos custos de exploração.

Esses impactos podem ser avaliados pelo que ocorreu na Mata Atlântica, hoje reduzida a menos de $10 \%$ da sua área original. No entanto, nos últimos anos, esses impactos têm sido mais sentidos na Amazônia e no Cerrado (MMA 2002). 


\subsubsection{Fauna e Flora}

Cada vez mais os impactos da ocupação humana fazem-se sentir na perda de habitats naturais, no desaparecimento de espécies e formas genéticas. São preocupantes as quantidades de animais e vegetais ameaçados de extinção.

O homem utiliza-se dos animais selvagens como alimento há milênios. Nos trópicos, ainda hoje persistem regiões onde os animais silvestres constituem, na prática, a única fonte de proteínas. No Brasil, a população rural de praticamente todas as regiões conta com os estoques dessas espécies como alternativa de alimento e renda extra.

As principais fontes de proteína para as populações tradicionais da Amazônia sempre foram à caça e a pesca. No Cerrado e na Caatinga, essa atividade também tem papel relevante na alimentação das populações tradicionais. Essa importância diminui muito na Mata Atlântica e no Pantanal. Por outro lado, a caça esportiva é forte nas regiões Sudeste e Sul, ocorrendo em outras regiões, quase sempre ofuscadas pela caça de subsistência. Os animais silvestres brasileiros também são procurados por sua pele, seus óleos, suas gorduras e seus produtos medicinais. Até os anos sessenta, o comércio de peles, no Brasil, era crescente (IBAMA 1995), tendo decaído substancialmente nas últimas décadas. Esse comércio muitas vezes atende à demanda externa e costuma ser altamente vantajoso, gerando lucros em especial para os intermediários.

A exploração de recursos da flora nativa está relacionada com seus usos, diretos e indiretos. Destacam-se a fabricação de ornamentos, medicamentos, alimentos, entre outros. As espécies vegetais utilizadas para efeitos ornamentais possuem grande importância econômica. Há, até mesmo, 420 delas monitoradas pela Convenção sobre o Comércio Internacional das Espécies da Fauna e Flora Selvagens Ameaçadas de Extinção - CITES. Não obstante esse monitoramento, diversas espécies utilizadas como ornamentais têm sido comercializadas sem nenhum controle dos órgãos ambientais.

As espécies vegetais com propriedades medicinais têm merecido atenção especial, seja pelo seu consumo direto, seja pelo seu grande potencial na produção de novos medicamentos. A crescente demanda da indústria farmacêutica em todo o 
mundo tem constituído preocupação, à medida em que algumas dessas espécies têm sido ameaçadas de extinção, pelo fato de na maioria das vezes serem utilizadas comercialmente partes essenciais para a reprodução dessas espécies, tais como raízes, sementes e flores.

A proteção às plantas medicinais representa garantia de utilização de matériaprima de alto valor para a população humana e, portanto, deve ser tratada como assunto de Estado. No entanto, nenhum programa eficiente tem sido desenvolvido para promover a conservação e o manejo sustentável desses recursos.

As atividades de fiscalização são mecanismos importantes no processo de proteção à biodiversidade e, particularmente, para evitar a superexploração da fauna e da flora. A deficiência da fiscalização é a causa principal dos problemas relacionados com a proteção da vida silvestre no Brasil. Essa deficiência é determinada por vários fatores, tais como: ausência de política abrangente para a conservação; falta de treinamento de pessoal especializado; falta de infra-estrutura, que dificulta a disponibilidade de informações sobre a biodiversidade $\mathrm{e} o$ estabelecimento de estratégias mais eficientes de controle; falta de apenação dos infratores.

Apesar da Lei de Crimes Ambientais ( $n^{\circ} 9.605$, de 13 de fevereiro de 1998), que considera crimes os atentados contra os recursos naturais, a apenação dos infratores continua ocorrendo raramente (MMA 2002).

\subsubsection{Oceanos}

Atualmente, os oceanos geram inúmeras riquezas, a exemplo da produção oficial de cerca de 86 milhões de toneladas de alimentos/ano. Além de deterem elevado potencial bioquímico e farmacológico e permitirem o tráfego de aproximadamente $80 \%$ de todo o comércio internacional, os oceanos constituem uma das últimas grandes fronteiras para a exploração de recursos minerais na Terra ao lado da região Amazônica e do continente Antártico.

Ressalta-se, ainda, a ocorrência de jazidas de óleo e gás localizadas em águas da margem continental brasileira e no domínio oceânico (águas profundas). 
Os oceanos cobrem cerca de $70 \%$ da superfície terrestre, no entanto o volume disponível para ocupação pelas diferentes espécies de seres vivos pode chegar a algo em torno de $99 \%$ do volume habitável provido pelo planeta. Enquanto nos ecossistemas terrestres a vida se restringe a uma estreita camada emersa, nos mares pode ser encontrada desde a superfície até a profundidade de 13 mil metros.

Não obstante, o uso indiscriminado dos oceanos e dos mares para a produção de alimentos, navegação comercial e despejo de efluentes vem causando danos, muitas vezes irreversíveis, a esse sistema.

A poluição nos oceanos faz-se sentir principalmente na zona costeira e adjacências, indicando que as principais fontes de poluição marinha são baseadas em terra. Consideram-se como principais contaminantes do meio marinho e suas respectivas fontes de contaminação os esgotos sanitários, os poluentes orgânicos persistentes, a radioatividade, os metais pesados, os nutrientes (eutrofização), os óleos (hidrocarbonetos), a movimentação de sedimentos e os resíduos sólidos.

Essa situação decorre da convergência dos principais vetores econômicos na zona costeira brasileira, demandando forte infra-estrutura de apoio logístico para a produção e a circulação de mercadorias (MMA 2002).

\subsubsection{Recursos Pesqueiros}

Analogamente, a forma de ocupação e a degradação da zona costeira e das bacias hidrográficas têm afetado decisivamente o equilíbrio das populações aquáticas e comprometido os principais recursos pesqueiros.

Diferentes atividades antrópicas vêm ameaçando crescentemente a ictiofauna e a pesca, entre elas o desmatamento das planícies de inundação e da mata ciliar, o garimpo, a poluição doméstica e industrial e a originária de insumos aplicados à agricultura, a construção de barragens e aterros e a canalização de rios, alterando os habitats (MMA 2002). 


\subsubsection{Atmosfera}

Até o presente, os fenômenos que mais ameaçam a atmosfera são a destruição da camada de ozônio e o efeito estufa.

Conceitua-se como proteção à atmosfera o conjunto de atividades voltado a defender a integridade e a recuperação da atmosfera que envolve a Terra, evitando os impactos adversos sobre a saúde da população e o meio ambiente em geral.

A camada de ozônio absorve a maior parte da radiação ultravioleta que incide na superfície da Terra. Essa radiação tem efeito deletério sobre os homens, afetando seu sistema imunológico e favorecendo o surgimento de um grande número de enfermidades. Os seres humanos não são os únicos afetados pelos malefícios dessa radiação. Todas as formas de vida, inclusive as plantas, podem ser debilitadas.

No entanto, os danos mais significativos dessa radiação deverão impactar os seres humanos pela sua interferência na produção agrícola, com a provável redução na oferta de alimentos. A vida marinha também poderia vir a estar seriamente ameaçada, por meio do comprometimento da produção de nutrientes pelos microorganismos que vivem na superfície do mar.

Os esforços do Brasil na proteção da camada de ozônio referem-se à implementação do Protocolo de Montreal e resultaram na publicação de vários instrumentos normativos, na elaboração de um programa nacional e no estabelecimento de iniciativas que regulamentam a produção (importação/exportação), consumo, recolhimento, recuperação e reciclagem das substâncias que destroem a camada de ozônio. Algumas dessas iniciativas são apoiadas com recursos provenientes de fundos internacionais, a exemplo do Fundo Multilateral para a Implementação do Protocolo de Montreal.

Entre as iniciativas que vêm sendo desenvolvidas, destaca-se o Programa Brasileiro de Eliminação da Produção e do Consumo das Substâncias que Destroem a Camada de Ozônio - PBCO, consagrando um conjunto de ações de cunho normativo, científico, tecnológico e econômico, com base nos projetos de conversão industrial e no diagnóstico de todos os segmentos produtores e usuários, com a definição de estratégias para eliminação da produção e do consumo das substâncias que destroem a camada de ozônio. O setor privado vem participando com recursos 
próprios em projetos para a agilização da conversão industrial, atendendo às metas estabelecidas no PBCO.

Efeito estufa é uma analogia utilizada para indicar o fenômeno que ocorre quando determinados gases presentes na atmosfera retêm a energia da mesma forma que os vidros de um carro fechado ou uma estufa. $O$ efeito estufa natural tem mantido a temperatura da Terra por volta de $30^{\circ} \mathrm{C}$ mais quente do que ela seria na ausência dele, possibilitando a existência de vida no planeta. Entre os gases que podem ocasionar esse fenômeno, destacam-se o vapor de água, o dióxido de carbono $\left(\mathrm{CO}_{2}\right)$, o ozônio $\left(\mathrm{O}_{3}\right)$, o metano $\left(\mathrm{CH}_{4}\right)$ e o óxido nitroso $\left(\mathrm{N}_{2} \mathrm{O}\right)$.

As atividades antrópicas estão acentuando as concentrações desses gases na atmosfera, ampliando, assim, a capacidade que possuem de absorver energia e aumentando, conseqüentemente, a temperatura do planeta.

As emissões antrópicas de dióxido de carbono - o gás que mais contribui para a intensificação do efeito estufa - decorrem principalmente da queima de carvão, petróleo e gás natural, assim como da destruição de florestas e outros "sumidouros" e "reservatórios" naturais que absorvem dióxido de carbono no ar.

O aquecimento global pelo aumento das temperaturas médias altas é uma das conseqüências mais prováveis do aumento das concentrações maiores de gases de efeito estufa na atmosfera, o que pode ainda provocar novos padrões de clima com repercussões nos regimes de ventos, chuvas e circulação geral dos oceanos.

A Convenção-Quadro das Nações Unidas sobre Mudanças do Clima foi assinada por mais de 150 países em junho de 1992 durante a ECO-92 no Rio de Janeiro. Esses países reconheceram a mudança do clima da Terra como "uma preocupação comum da humanidade".

O objetivo central da Convenção é o de alcançar “a estabilização das concentrações de gases de efeito estufa na atmosfera num nível que impeça uma interferência antrópica perigosa no sistema do clima. Esse nível deverá ser alcançado num prazo suficiente que permita aos ecossistemas se adaptarem naturalmente à mudança do clima, que assegure que a produção de alimentos não seja ameaçada e que permita ao desenvolvimento econômico prosseguir de maneira sustentável" (MMA 2002). 


\subsubsection{Produção e Consumo de Energia}

A produção e o consumo de energia estão na origem dos principais impactos ambientais que a sociedade moderna é chamada a enfrentar. Grande parte desses impactos decorre da queima de substâncias fósseis utilizadas largamente como combustíveis. O principal problema local é a poluição do ar nas grandes cidades e, no planeta, a mudança climática derivada do efeito estufa.

Políticas para reduzir os impactos da produção e do consumo de energia sobre o meio ambiente podem ser concebidas e implementadas tanto pela demanda como pela oferta de energia.

No primeiro caso, o objetivo é possibilitar um uso mais eficiente de todas as formas de energia pela sociedade. Com efeito, o grande desafio que se apresenta para um país em desenvolvimento, como o Brasil, é promover o crescimento da economia do país e o aumento do nível de bem-estar da população sem, com isso, incorrer em aumento proporcional do consumo de energia. Isso implica que a dissociação entre as taxas de crescimento econômico e as taxas de crescimento do consumo de energia seja requisito fundamental para que o país se desenvolva com um mínimo dano ambiental. Esse objetivo é considerado muitas vezes para estimular o uso mais racional da energia por meio do monitoramento de variáveis externas ao sistema energético, tais como as mudanças no sistema de transporte ou no parque industrial, mas que repercutam igualmente sobre a eficiência energética.

No segundo caso, trata-se de, simultaneamente, substituir os combustíveis fósseis por outras fontes renováveis e menos poluentes, tais como a energia hidráulica, a biomassa e a energia solar e de reduzir os impactos ambientais advindos da produção de todas as formas de energia.

Uma das utilizações dos combustíveis fósseis é como combustível para os veículos automotores que produzem mais poluição atmosférica do que qualquer outra atividade humana isolada. As grandes metrópoles brasileiras padecem de enormes congestionamentos diários. Na cidade de São Paulo, esses congestionamentos têm alcançado até $200 \mathrm{Km}$ de extensão nos horários de pico do dia. Estima-se que esses congestionamentos provoquem um desperdício médio de cerca de US\$ 325 milhões / ano (MMA 2002). 


\subsubsection{Poluição Ambiental}

\section{Poluição do Ar}

A maior concentração industrial do país e os maiores índices de lançamento de poluentes originários de veículos automotores ocorrem na região metropolitana de São Paulo, cuja situação se agrava com a ocorrência de inversão térmica. Circulam na região metropolitana de São Paulo mais de 5 milhões de veículos emitindo $73 \%$ de $\mathrm{SO}_{2}$ e $89 \%$ de $\mathrm{NO}_{2}$, dois gases presentes nas emissões de diesel e de gasolina.

Essa frota aumenta em aproximadamente 250 mil veículos a cada ano, sendo responsável por $90 \%$ da poluição atmosférica nessa região.

Outras regiões metropolitanas, como Rio de Janeiro, Belo Horizonte, Salvador, Recife, Porto Alegre e Curitiba, têm sido crescentemente afetadas por problemas de poluição, em grande parte também causados pelas emissões de veículos automotores.

Isso é fato, não obstante o ocorrido em São Paulo, onde o declínio da concentração de $\mathrm{SO}_{2}$ no ar, que tem sido observado desde o início da década de 1980, seja um dos reflexos das iniciativas de controle da poluição do ar de origem industrial empreendidas pela Companhia Estadual de Tecnologia de Saneamento Ambiental - CETESB. Trata-se de iniciativas voltadas à instalação de equipamentos de controle da emissão de enxofre e à substituição de caldeiras movidas a diesel por outras a gás natural e, também, à transferência de instalações industriais da região metropolitana para o interior do estado (MMA 2002).

\section{Poluição Hídrica}

A situação da poluição dos rios e lagos no Brasil é, de modo geral, muito grave. Rios, reservatórios, praias e baías nas proximidades das maiores áreas urbanas do Brasil encontram-se poluídos em decorrência do destino inadequado dado a esgotos, efluentes industriais e resíduos sólidos.

Grandes rios e mesmo pequenos córregos que atravessam as aglomerações no Brasil são, muitas vezes, usados como evacuadores de águas servidas e depósito de lixo. Além de problemas de poluição e de proliferação de vetores, por ocasião de chuvas intensas, esses cursos de água costumam transbordar, ampliando os problemas sanitários e ambientais. 
Os nutrientes presentes nos esgotos urbanos e nos insumos agrícolas têm, por outro lado, aumentado o problema de eutrofização de lagos, represas, estuários e baías. A eutrofização impede o aproveitamento da água para atividades de lazer e recreação, onera o custo de tratamento de água, está associada a episódios recorrentes de mortandade de peixes e pode levar à produção de algas tóxicas que trazem sérios riscos à saúde humana.

Além desses problemas de caráter mais urbano, há problemas de poluição em pontos específicos do país, como aqueles decorrentes do mercúrio, causados pelas atividades de garimpo e mineração (região Norte) e a poluição tóxica, causada pelo carreamento do solo por ocasião de chuvas em regiões que abrigam práticas agrícolas intensivas em uso de agrotóxico.

De modo geral, os problemas mais graves na área de poluição dos sistemas hídricos no país podem ser assim descritos: poluição por esgotos domésticos; poluição industrial, disposição dos resíduos sólidos, poluição difusa de origem agrícola, poluição acidental, eutrofização de lagos e represas, salinização de rios e açudes, poluição por mineração, falta de proteção dos mananciais superficiais e subterrâneos.

Os aspectos técnicos de tratamento e prevenção da poluição hídrica são bastante conhecidos. $\mathrm{O}$ arcabouço legal e normativo da área ambiental também é farto e suficiente para o exercício do controle. No entanto, observa-se sua prática muito aquém do necessário, tanto na esfera federal como na estadual e local. Faz-se premente a viabilização de ações que, por um lado, atuem no equacionamento da diminuição e do controle das fontes de poluição e, por outro lado, promovam iniciativas de descontaminação dos cursos de água (MMA 2002).

\subsection{Gestão Ambiental e Desenvolvimento}

Por Gestão Ambiental entende-se o conjunto de princípios, estratégias e diretrizes de ações e procedimentos para proteger a integridade dos meios físico e biótico, bem como a dos grupos sociais que deles dependem.

A ISO 14001 define o sistema de gestão ambiental como: 
- A parte do sistema de gestão global que inclui estrutura organizacional, atividades de planejamento, responsabilidades, práticas, procedimentos, processos e recursos para desenvolver, implementar, atingir, analisar criticamente e manter a política ambiental.

\subsubsection{Sistemas de Gestão}

O desenvolvimento sustentável exige da sociedade moderna um compromisso de construção do futuro através da elaboração de planejamento estratégico (longo prazo) das organizações formalmente constituídas que utilizam os Sistemas de Gestão como ferramenta gerencial.

(....) Os Programas de Qualidade, Segurança, Saúde, Meio Ambiente e Responsabilidade Social iniciam nas empresas através do seu entendimento e para que serve o Programa ao negócio. O grau de sofisticação e o nível de esforço requerido variam consideravelmente entre as empresas. As dimensões dos programas são determinadas primeiro pelo potencial de impactos nas operações, a tecnologia e a influência nos valores e visão estabelecidos pela empresa, e segundo pelo tamanho e complexidade da Organização (West 1995, p. 1).

\subsubsection{Sistema Nacional de Licenciamento Ambiental}

O licenciamento ambiental, atividade típica de Estado, é cada vez mais exigido em prol de uma atuação eficiente do controle e da gestão ambiental. Embora do ponto de vista legal e normativo existam diretrizes para a atividade, os principais problemas constatados para a implementação plena do licenciamento ambiental referem-se a: falta de regulamentação em âmbito estadual da legislação básica e das diretrizes nacionais, despreparo técnico da administração superior e dos quadros técnicos em geral, necessidade de descentralização das atividades de fiscalização e acompanhamento das atividades, restrição das atividades em razão da limitação de recursos para planejamento e execução de fiscalização e monitoramento, falta de um sistema de monitoramento e vigilância dos impactos ambientais e ausência de um 
sistema de informações ambientais para esclarecer os empreendedores e o público em geral (MMA 2002).

\subsubsection{Modelo de Gestão da Fundação para o Prêmio Nacional da Qualidade}

O modelo de gestão composto pelos Critérios de Excelência define o que a organização deve fazer para obter sucesso na busca pela excelência no desempenho. Através da liderança forte da alta direção que focaliza as necessidades dos clientes e do mercado, as operações da organização são planejadas para melhor atender esse conjunto de necessidades, levando-se em conta os recursos disponíveis.

Os três primeiros Critérios formam um bloco que pode ser denominado de planejamento.

$\mathrm{O}$ atendimento dessas necessidades em conformidade com a estratégia e os planos de ação é feito através de pessoas e de processos. Esse segundo bloco de Critérios representa a execução do planejamento. Os resultados da organização, que servem para acompanhar a satisfação dos clientes, a situação do mercado, as finanças, a gestão das pessoas, a gestão de fornecedores, bem como o desempenho dos produtos e dos processos organizacionais, podem ser considerados como o bloco de controle.

Finalmente, o sistema de informação e análise representa a inteligência da organização e a base de sustentação das ações planejadas e executadas em cada um dos blocos anteriores. Esse é o bloco de tomada de ação em função das análises críticas realizadas. 


\section{ESTRATÉgIAS E PLANOS DE AÇÃO}

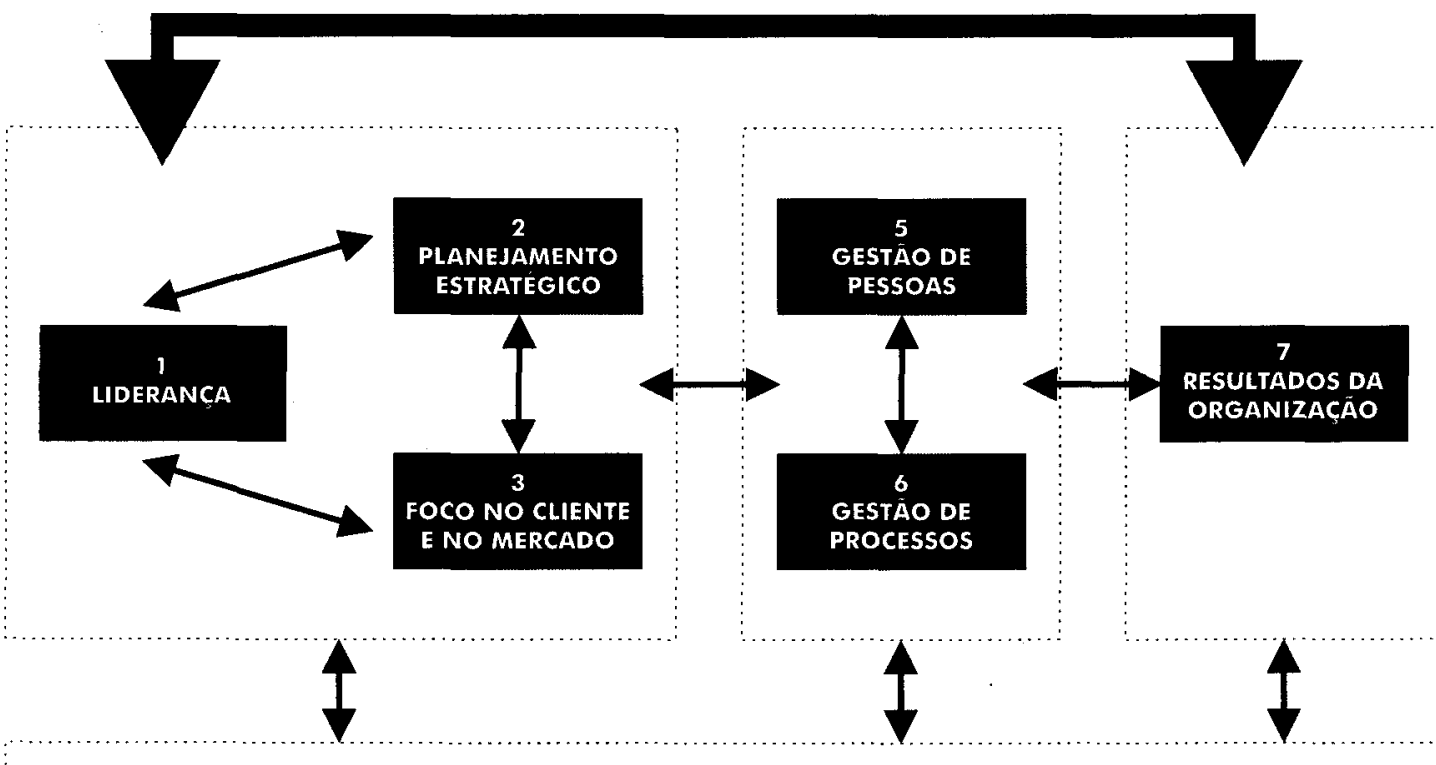

4 INFORMAÇÄO E ANÁLISE

Figura 2 - Estrutura dos Critérios - Um Enfoque Sistêmico

Fonte: FPNQ (2000, p. 17)

\subsubsection{Abordagem de Processo}

Qualquer atividade, ou conjunto de atividades que usa recursos para transformar insumos (entradas) em produtos (saídas) pode ser considerado como um processo.

Para que as organizações funcionem de forma eficaz, elas têm de identificar e gerenciar processos inter-relacionados e interativos. Freqüentemente, a saída de um processo resultará diretamente na entrada do processo seguinte. A identificação sistemática e a gestão dos processos empregados na organização e, particularmente, as interações entre tais processos são conhecidas como "abordagem de processos".

A intenção da Associação Brasileira de Normas Técnicas - ABNT NBR ISO 9000:2000 é de encorajar a adoção da abordagem de processo, para a gerência de uma organização.

A Figura 3 ilustra o modelo de um sistema de gestão da qualidade baseado no Processo. (ABNT NBR ISO 9000:2000, p. 3). 


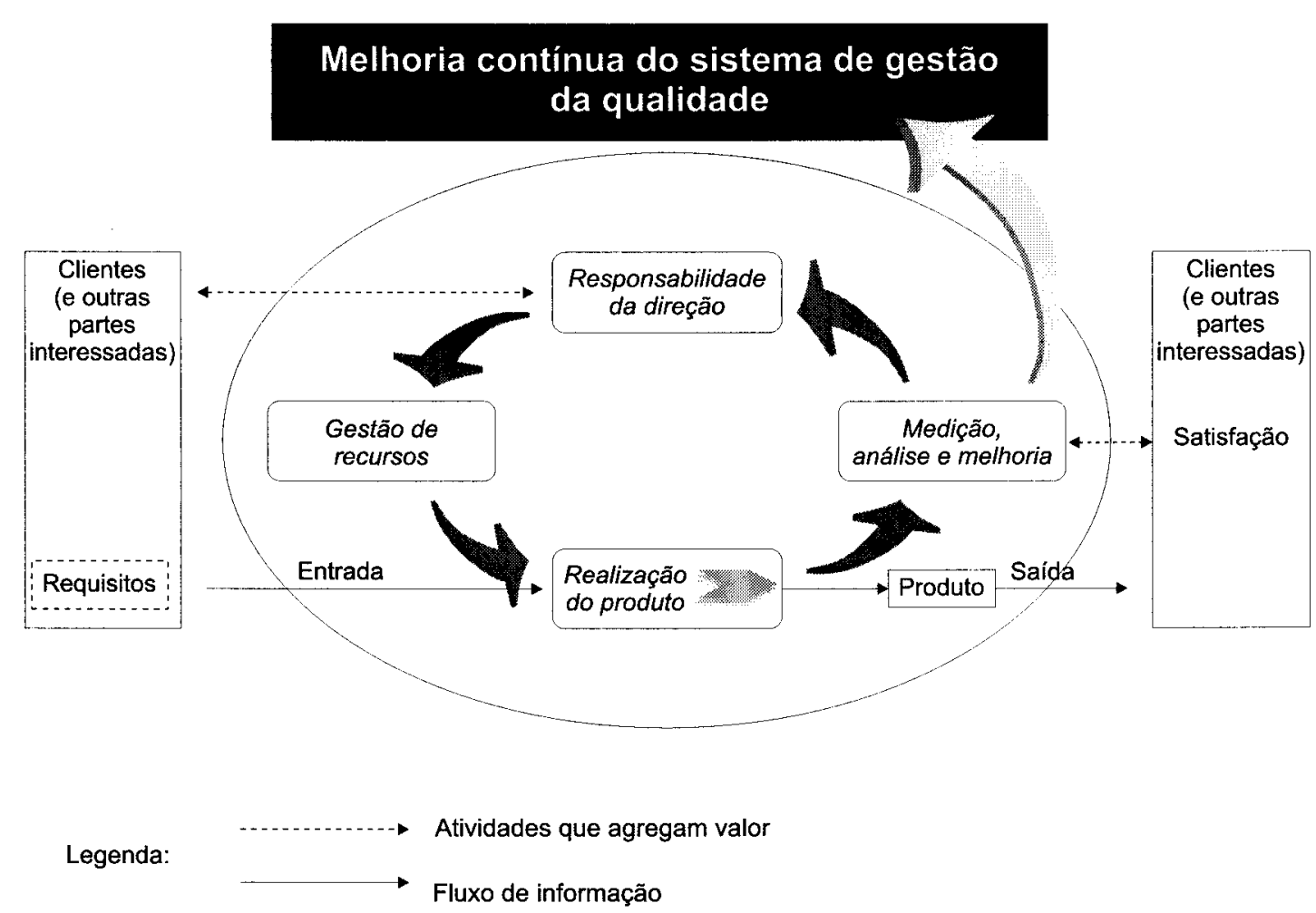

Figura 3 - Modelo de um Processo Baseado no Sistema de Gestão da Qualidade

Fonte: ABNT NBR ISO 9000 (2000, p. 4)

\subsubsection{Sistemas de Gestão Ambiental}

O primeiro padrão adotado formalmente para o sistema de gestão ambiental foi desenvolvido em 1992 pela British Standards Institution - BSI; a BS 7750 tornou-se operacional para certificação em 1995. O objetivo foi desenvolver um sistema de gestão ambiental compreensivo e genérico o suficiente para aplicação em todos os setores de negócios.

A BS 7750 serviu como base de negociação para a adoção de um sistema de gestão ambiental, incluindo a União Européia e a International Standardization for Organization - ISO. Na União Européia foi negociada com a indústria, grupos ambientais e partes interessadas stakeholders a Eco-Management and Audit Scheme EMAS. Foi criada como uma certificação voluntária para o sistema de gestão ambiental das empresas e ajuda na avaliação dos programas em direção à melhoria contínua e desempenho ambiental (Krut e Gleckman 1998, p. 5). 
A EMAS contém elementos chaves que estão ausentes na ISO 14001 (Quadro 2); é um padrão de excelência e a ISO é um método de padronização; foi criada pelo Conselho da Comunidade Européia e Representantes do Governo ligados ao Ministério do Meio Ambiente.

A ISO 14001 foi criada pela Associação Industrial Internacional ligada ao Ministério da Indústria e Comércio.

Com base nas diferenças e o acesso público às informações entre EMAS e a ISO 14001 as autoridades da Europa propõem a ISO 14001 como uma etapa do EMAS, conforme ilustra a Figura 4 (Krut e Gleckman 1998, p. 16). 
Quadro 2 - EMAS comparado com a ISO 14001

\begin{tabular}{|c|c|c|}
\hline Elemento & EMAS & ISO 14001 \\
\hline $\begin{array}{l}\text { Guia de Princípios } \\
\text { Termos de Referência }\end{array}$ & $\begin{array}{l}\text { "... Um Programa comunitário da Política e } \\
\text { Ações em relação ao Meio Ambiente e } \\
\text { Desenvolvimento Sustentável..." } \\
\text { - Proteção do Meio Ambiente } \\
\text { - Prevenir, reduzir e eliminar a poluição } \\
\text { - Princípio poluidor pagador } \\
\text { - Assegurar a gestão de recursos } \\
\text { - Uso de tecnologia limpa }\end{array}$ & $\begin{array}{l}\text { Título: Gestão ambiental } \\
\text { Escopo: Padronização de Sistemas e } \\
\text { ferramentas no campo da Gestão } \\
\text { Ambiental }\end{array}$ \\
\hline Situação Legal & $\begin{array}{l}\text { - Regulamentação voluntária } \\
\text { - Integrada no Sistema Legal da União } \\
\text { Européia e de seus Países Membros. }\end{array}$ & $\begin{array}{l}\text { - As normas Série ISO são voluntárias } \\
\text { - Busca a Padronização Industrial } \\
\text { - Não tem relação com o Regime Legal } \\
\text { - Tendem a tornar-se requisitos para o } \\
\text { Comércio Internacional }\end{array}$ \\
\hline Uso & $\begin{array}{l}\text { - Limitado a localidades industriais da } \\
\text { União Européia }\end{array}$ & $\begin{array}{l}\text { - Qualquer organização / atividade } \\
\text { - Mundial }\end{array}$ \\
\hline
\end{tabular}


Quadro 2 - EMAS comparado com a ISO 14001 - cont.

\begin{tabular}{|c|c|c|}
\hline Elemento & $x^{2}$ & ISO 14001 \\
\hline Compromisso Legal & $\begin{array}{l}\text { - A conformidade com diretivas e } \\
\text { regulamentos ambientais é necessária } \\
\text { para a Certificação }\end{array}$ & $\begin{array}{l}\text { - O compromisso de conformidade com a } \\
\text { Política Ambiental é requerido. } \\
\text { - A conformidade não é essencial para } \\
\text { obtenção ou cancelamento da } \\
\text { certificação }\end{array}$ \\
\hline Concepção de Auto Regulação & $\begin{array}{l}\text { - Estrutura legal } \\
\text { - Verificação externa } \\
\text { - Avaliação dos elementos (comissão da } \\
\text { União Européia) } \\
\text { - Compromisso de conformidade }\end{array}$ & $\begin{array}{l}\text { - A critério das empresas } \\
\text { - Escolha do organismo de certificação }\end{array}$ \\
\hline Declaração Ambiental & $\begin{array}{l}\text { - Pública } \\
\text { - Verificação externa } \\
\text { - Contém os elementos da EMAS } \\
\text { - Melhoria contínua do desempenho } \\
\text { ambiental }\end{array}$ & $\begin{array}{l}\text { - Avaliação pelos funcionários da empresa } \\
\text { - Somente a Política Ambiental é } \\
\text { disponibilizada ao público }\end{array}$ \\
\hline Política Ambiental & $\begin{array}{l}\text { Compromisso com a melhoria contínua } \\
\text { do desempenho ambiental }\end{array}$ & $\begin{array}{l}\text { Compromisso com a melhoria contínua } \\
\text { do Sistema de Gestão Ambiental }\end{array}$ \\
\hline
\end{tabular}


Quadro 2 - EMAS comparado com a ISO 14001 - cont.

\begin{tabular}{|c|c|c|}
\hline Elemento & EMAS & ISO 14001 \\
\hline Desempenho Ambiental & $\begin{array}{l}\text { - A análise crítica do desempenho } \\
\text { ambiental } \\
\text { - A certificação EMAS pode ser cancelada } \\
\text { por resultados inadequados em relação } \\
\text { às metas ambientais estabelecidas }\end{array}$ & $\begin{array}{l}\text { - Melhoria contínua do Sistema de Gestão } \\
\text { Ambiental deve ser demonstrado pela } \\
\text { empresa (internamente) }\end{array}$ \\
\hline $\begin{array}{l}\text { Uso para Divulgação } \\
\text { (Marketing) }\end{array}$ & $>$ Expressamente proibido & $\begin{array}{l}\text { A certificação é utilizada pela empresa } \\
\text { para relações comerciais e públicas } \\
\text { Divulgação da certificação }\end{array}$ \\
\hline Auditorias & $\begin{array}{l}\text { - Sistema EMAS } \\
\text { - Melhoria contínua da empresa } \\
\text { - Desempenho ambiental }\end{array}$ & $\begin{array}{l}\text { - Sistema de Gestão } \\
\text { - Padrões das empresas }\end{array}$ \\
\hline Discrição Corporativa & $\begin{array}{l}\text { Limitada pelas salvaguardas, tais como: } \\
\text { - Política ambiental pública } \\
\text { - } \text { Certificação por } 3^{a} \text { parte } \\
\text { - } \begin{array}{l}\text { Regulamentos da Comissão União } \\
\text { Européia }\end{array}\end{array}$ & $\begin{array}{l}\text { - } \\
\text { A base do esquema de certificação } \\
\text { - O desempenho ambiental é somente } \\
\text { garantido através da avaliação do } \\
\text { Sistema de Gestão Ambiental } \\
\text { - A empresa decide quais informações } \\
\text { podem ser divulgadas }\end{array}$ \\
\hline
\end{tabular}


Quadro 2 - EMAS comparado com a ISO 14001 - cont.

\begin{tabular}{|c|c|c|}
\hline Elemento & EMAS & ISO 14001 \\
\hline $\begin{array}{c}\text { Avaliação do Sistema } \\
\text { de Gestão é garantida por: }\end{array}$ & $\begin{array}{l}\text { - Declaração pública } \\
\text { - Prazo final } \\
\text { - Auditorias } \\
\text { - Avaliação e quantificação dos elementos }\end{array}$ & - Discrição da empresa \\
\hline $\begin{array}{l}\text { Verificação do } \\
\text { Sistema de } \\
\text { Gestão Ambiental }\end{array}$ & $\begin{array}{l}\text { - Requerida verificação por organismo de } \\
3^{a} \text { parte (credenciado) }\end{array}$ & $\begin{array}{l}\text { - A Empresa escolhe o organismo de } 3^{a} \\
\text { parte ou emite uma certificação de } 1^{a} \\
\text { parte (Externa) } \\
\text { - Verificação não é requerida }\end{array}$ \\
\hline Divulgação & $\begin{array}{l}\text { - É requerida a comunicação externa } \\
\text { sobre as informações ambientais de } \\
\text { cada planta específica para as } \\
\text { autoridades governamentais e o público }\end{array}$ & $\begin{array}{l}\text { Divulgação de informações é uma } \\
\text { discrição da empresa }\end{array}$ \\
\hline Cadeias de Fornecedores & $\begin{array}{l}\text { - Assegura que apliquem nas suas plantas } \\
\text { o padrão ambiental equivalente das } \\
\text { empresas contratantes }\end{array}$ & $\begin{array}{l}\text { - Não está incluído na norma, há forte } \\
\text { interesse que isso venha a tornar-se uma } \\
\text { prática de mercado }\end{array}$ \\
\hline
\end{tabular}

Fonte: Krut e Gleckman (1998, p. 18) 


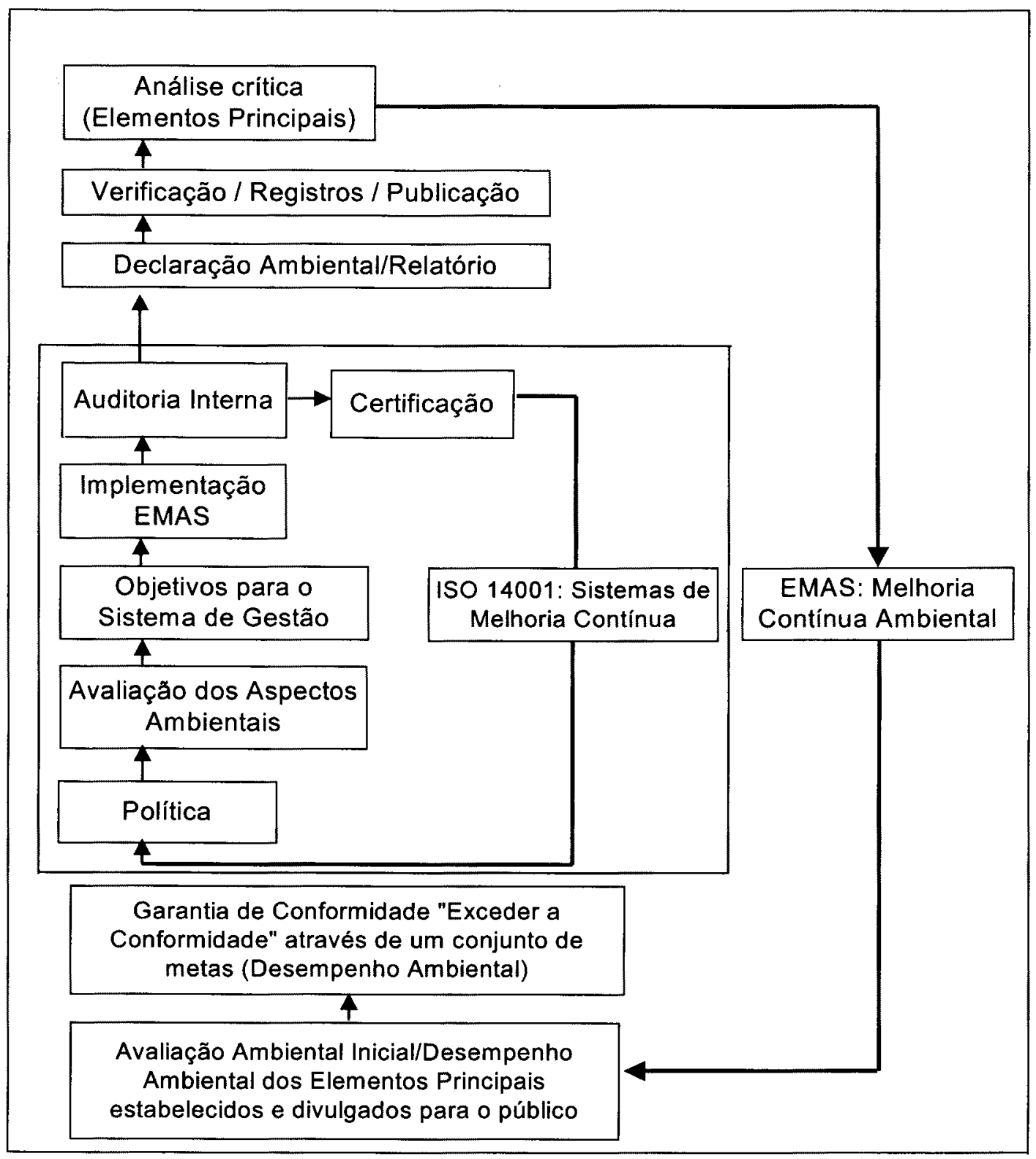

Figura 4 - A ISO 14001 - Sistema de Gestão Ambiental como um Subconjunto da EMAS

Fonte: Krut e Gleckman (1998, p. 16) 
As normas internacionais de gestão ambiental têm por objetivo prover às organizações os elementos de um sistema de gestão ambiental eficaz, passível de integração com outros requisitos de gestão, de forma a auxiliá-las a alcançar seus objetivos ambientais e econômicos.

A ABNT NBR ISO 14001 especifica os requisitos do sistema de gestão ambiental de forma a aplicar-se a todos os tipos e portes de organizações e para adequar-se a diferentes condições geográficas, culturais e sociais.

A base desta abordagem é representada na Figura 5 - ABNT NBR ISO 14001 (1996, p. 2).

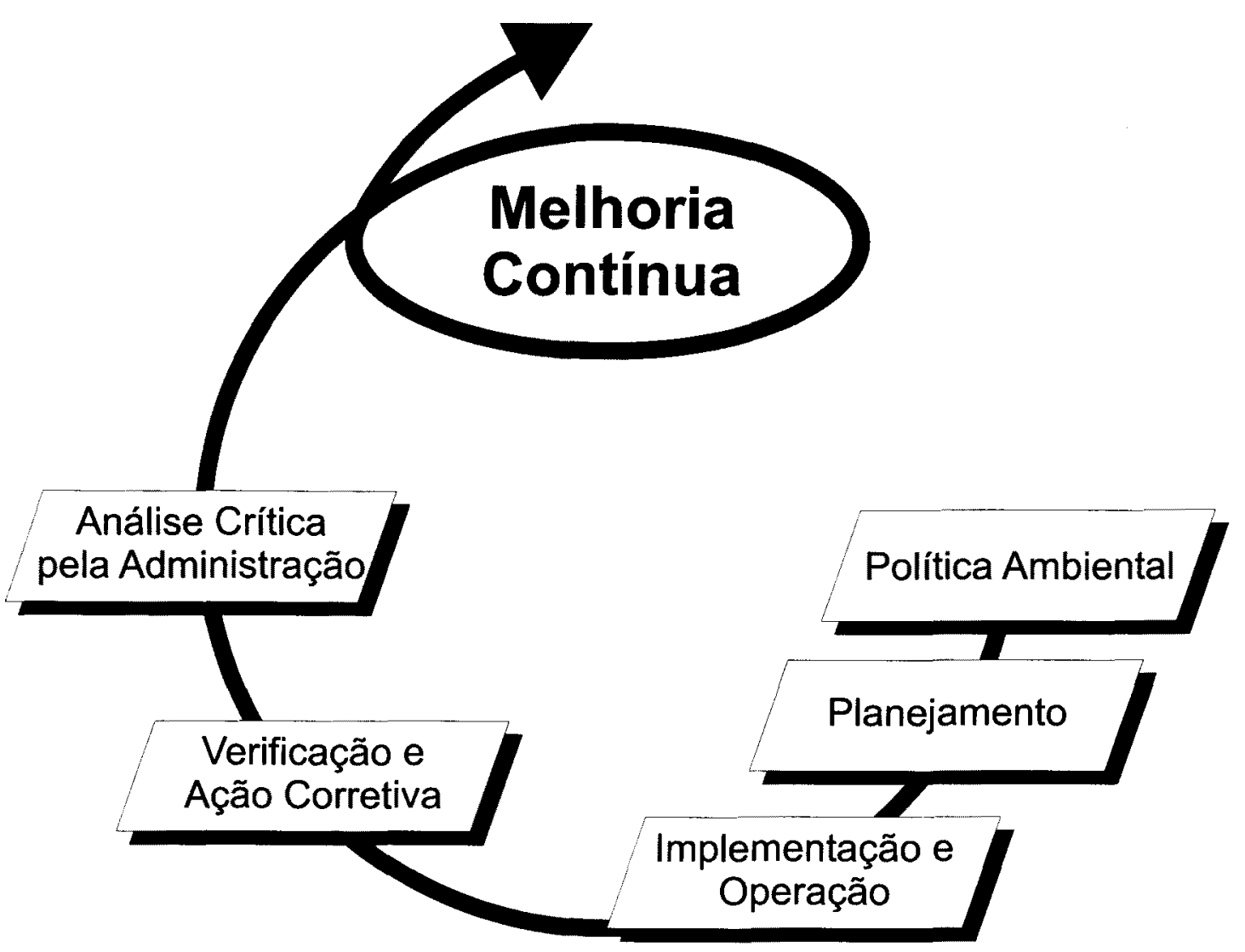

Figura 5 - Modelo do Sistema de Gestão Ambiental

Fonte: ABNT NBR ISO 14001 (1996, p. 3) 


\subsubsection{Sistema de Gestão de Segurança e Saúde no Trabalho}

A especificação OHSAS 18001 da série de Avaliação da Segurança e Saúde no Trabalho (OHSAS) fornece os requisitos para um Sistema de Gestão da Segurança e Saúde no Trabalho - SST, permitindo a uma organização controlar seus riscos de acidentes e doenças ocupacionais e melhorar seu desempenho. Risk Tecnologia, OHSAS 18002 (2001, p. 6).

A Figura 6 apresenta os elementos do Sistema de Gestão da Segurança e Saúde no Trabalho (SST).

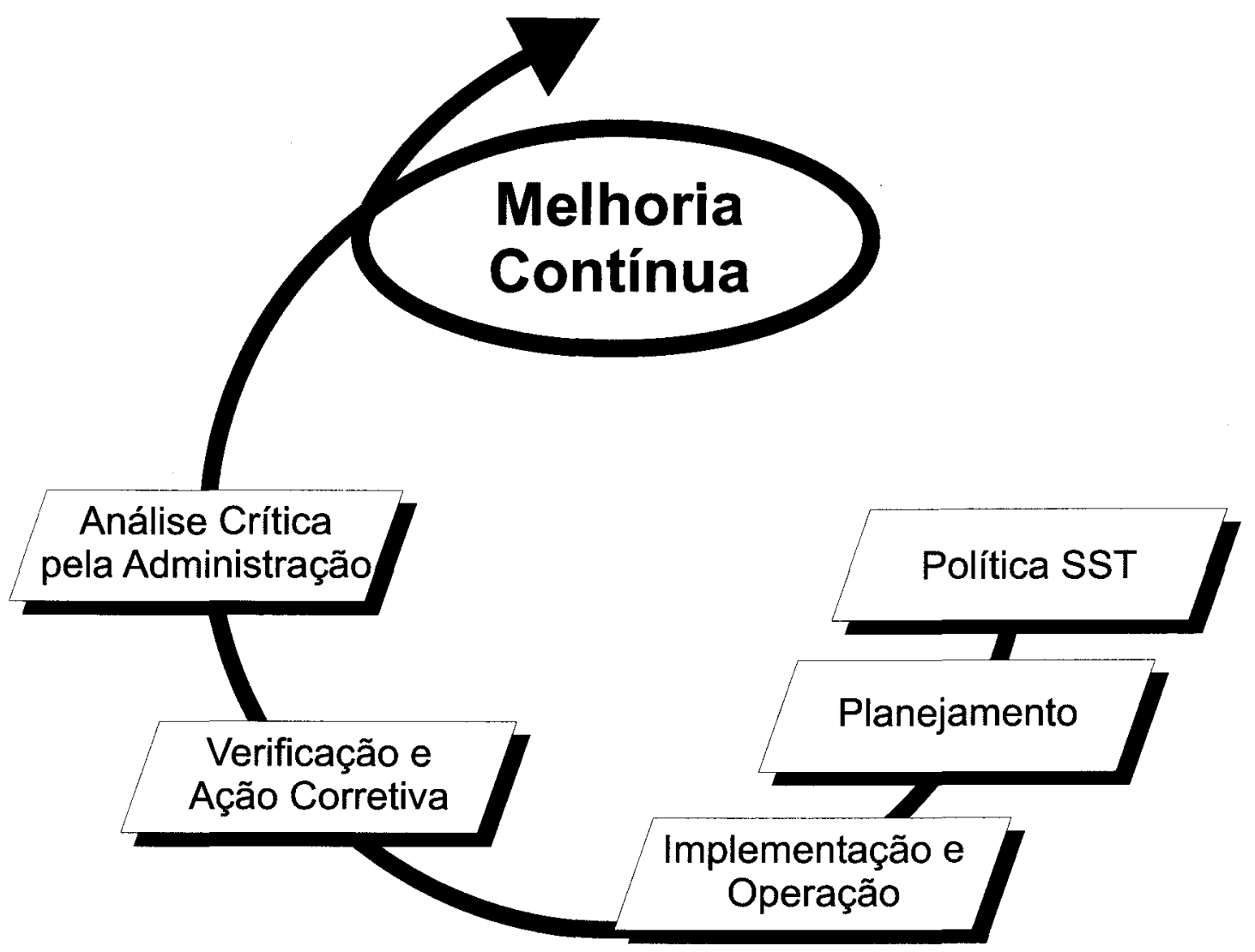

Figura 6 - Elementos do Sistema de Gestão de SST

Fonte: Risk Tecnologia, OHSAS 18002 (2001, p. 11)

SST - Segurança e Saúde no Trabalho 
A abordagem com base no guia da HSE Successful Health and Safety Management (Gerenciamento de Segurança e Saúde bem sucedidos) HS (G) 65 é destinada a organizações que desejam fundamentar o seu Sistema de Gerenciamento e Segurança e Saúde Ocupacional - SSO neste enfoque.

A Figura 7 apresenta a abordagem HS (G) 65, BS 8800 (1996, p. 6).
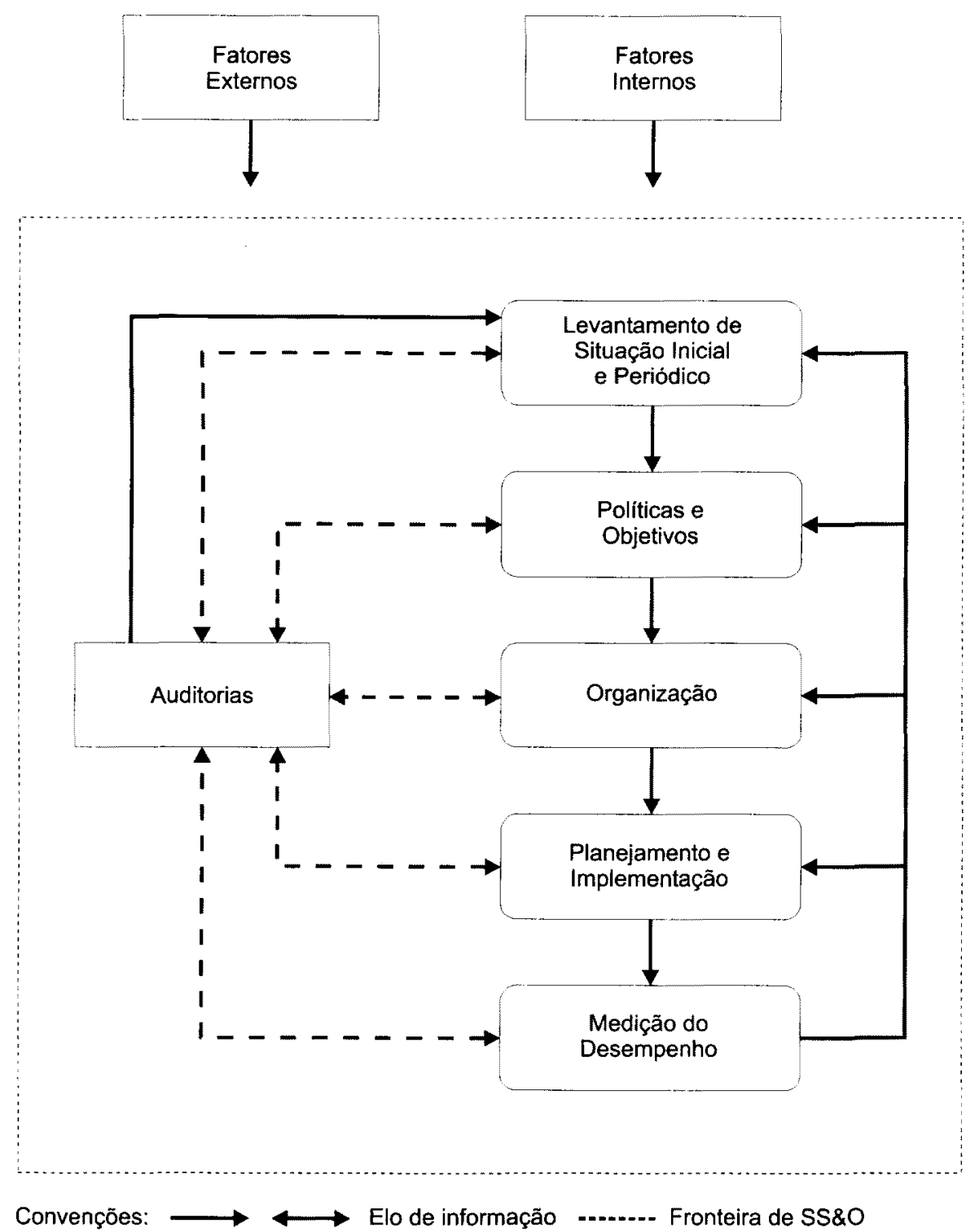

Figura 7 - Gerenciamento de Segurança e Saúde com Base na Abordagem

HS (G) 65

Fonte: Norma BS 8800 (1996, p. 6)

HS (G) - Health and Safety (Guide) 
A alta administração deve demonstrar proatividade nas ações de prevenção de acidentes pelas suas ações, comportamento e responsabilidades através de programas que englobam os elementos chaves do sistema de gestão de segurança.

Os elementos genéricos do sistema de gestão em larga aplicabilidade para grandes e pequenas empresas incluem: políticas de segurança e saúde, implementação da política da empresa e a definição de responsabilidades.

Aspectos chaves de implementação estão envolvidos com: "diga o que você faz", "faça o que você disse", "meça" e "melhore" resultará no desempenho econômico e efetivo (ICHEME 1994, p. 6).

A Figura 8 apresenta a estrutura típica do sistema de gestão (ICHEME, 1994).

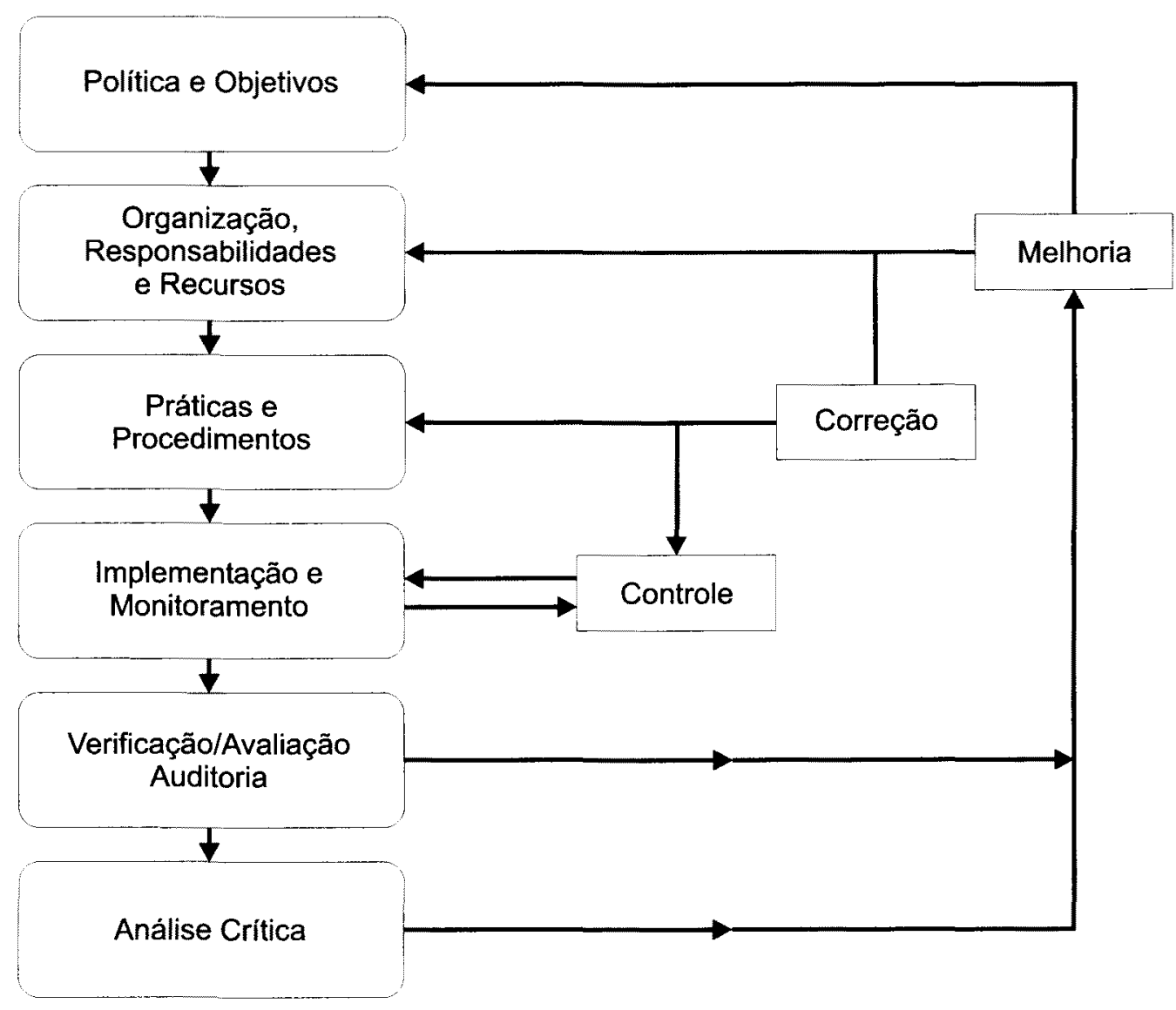

Figura 8 - Estrutura Típica do Sistema de Gestão

Fonte: ICHEME (1994, p. 6) 
(....) Em complemento aos elementos do sistema de gestão de segurança um número de requisitos chaves são importantes para a aplicação prática, efetividade e sucesso do sistema. São eles:

- É necessário que o sistema seja formal, documentado em detalhe e englobe objetivos e escopo, ferramentas e procedimentos, recursos e responsabilidades, planos e processo de medição.

- O sistema deve ser flexível para aplicação com sucesso em grande extensão para todos os tipos de perigos.

- O nível gerencial é responsável pela efetividade do sistema.

A função das autoridades de controle no sistema de gestão de segurança é verificar:

- A adequação do sistema de gestão de segurança.

- Que o monitoramento e acompanhamento do processo são consistentes com perigos e riscos da instalação.

Em resumo, a função das autoridades de controle é verificar que aquilo que o sistema disse que faz, está sendo feito (ICHEME 1994, p. 8).

\subsubsection{Sistema de Gestão em Segurança, Saúde e Meio Ambiente (SHE) do Instituto de Química Industrial (ICI)}

O sistema de gestão ICI / SHE é um plano "planejar-fazer-verificar" em um círculo de melhoria contínua "loop" com sete elementos básicos: políticas, padrões, diretrizes para o uso, procedimentos local, auditoria, carta de garantia e análise crítica da política (ICHEME 1994, p. 9).

A Figura 9 representa o Sistema de Gestão ICI / SHE (ICHEME 1994). 


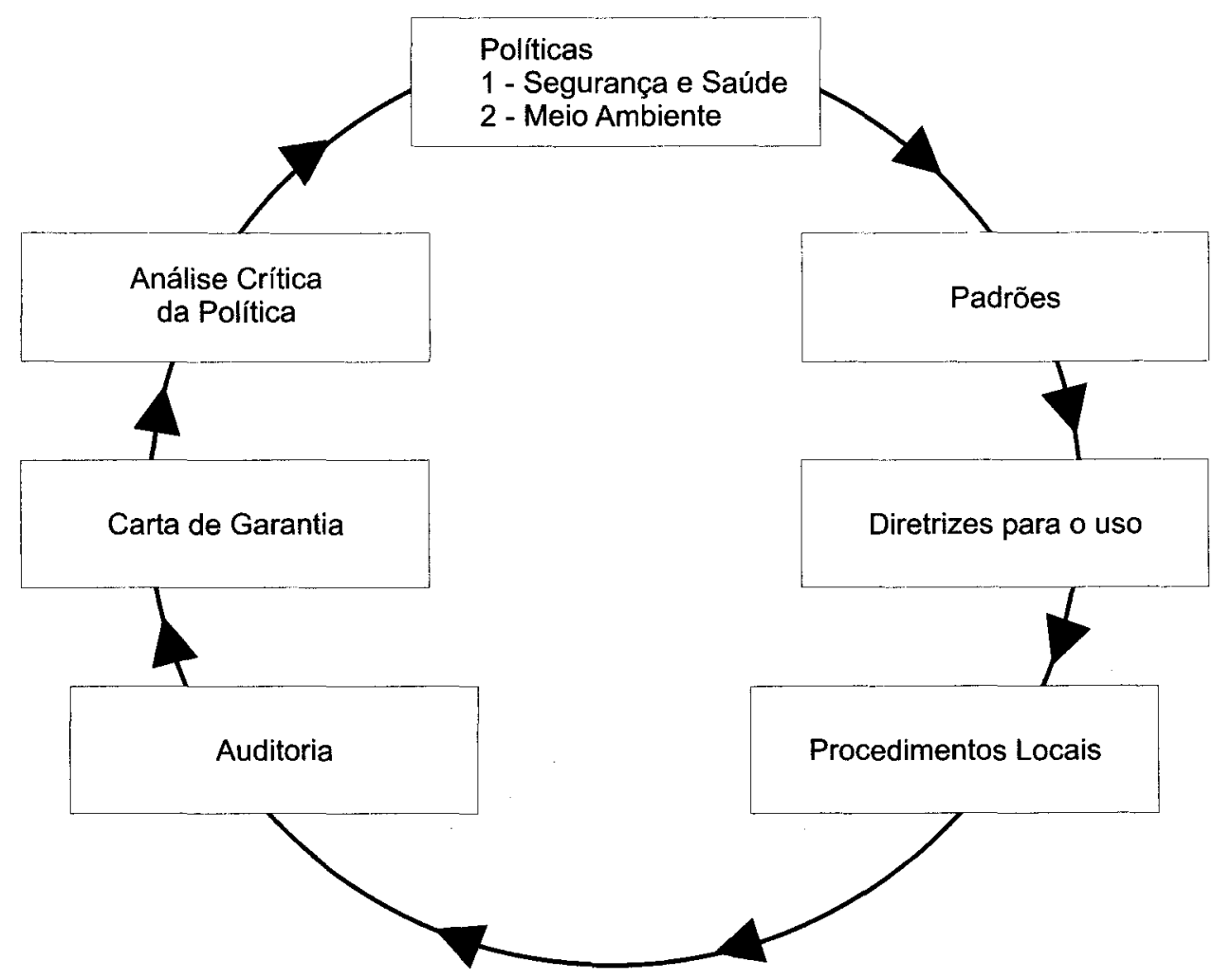

\section{Figura 9 - Sistema de Gestão ICI / SHE}

Fonte: ICHEME (1994, p. 9)

\subsubsection{Responsabilidade Social}

A Norma Internacional de Responsabilidade Social SA 8000:2001 ( $2^{\mathrm{a}}$ versão) é uniforme e auditável permitindo a verificação de sistema por terceira parte.

A SA 8000 especifica requisitos de responsabilidade social para possibilitar a uma empresa:

a) Desenvolver, manter e executar políticas e procedimentos com o objetivo de gerenciar aqueles temas, os quais ela possa controlar ou influenciar.

b) Demonstrar para as partes interessadas que as políticas, procedimentos e práticas estão em conformidade com os requisitos da SA 8000 .

Os requisitos da SA 8000 devem se aplicar universalmente em relação à localização geográfica, setor da indústria e tamanho da empresa. 
A empresa deve atender às leis nacionais e outras aplicáveis, a outros requisitos aos quais a empresa tenha se obrigado e a Norma SA 8000. Quando mais de um instrumento tratarem do mesmo tema, a disposição que for mais rigorosa se aplica.

A empresa deve também respeitar os princípios dos seguintes instrumentos internacionais:

- Convenções OIT 29 e 105 (Trabalho Forçado e Trabalho Escravo).

- Convenção OIT 87 (Liberdade de Associação).

- Convenção OIT 98 (Direito de Negociação Coletiva).

- Convenção OIT 100 e 111 (Remuneração equivalente para trabalhadores masculinos e femininos por trabalho equivalente; Discriminação).

- Convenção OIT 135 (Convenção dos Representantes dos Trabalhadores).

- Convenção OIT 138 e Recomendação 146 (Idade Mínima e Recomendação).

- Convenção OIT 155 e Recomendação 164 (Segurança e Saúde Ocupacional).

- Convenção OIT 159 (Reabilitação Vocacional e Emprego / Pessoas com Deficiência).

- Convenção OIT 177 (Trabalho Doméstico).

- Convenção OIT 182 (As Piores Formas de Trabalho Infantil).

- Declaração Universal dos Direitos Humanos.

- Convenção das Nações Unidas Sobre os Direitos da Criança.

- Convenção das Nações Unidas para Eliminar Todas as Formas de Discriminação Contra as Mulheres.

\subsubsection{Requisitos de Responsabilidade Social}

1. Trabalho Infantil

2. Trabalho Forçado

3. Saúde e Segurança

4. Liberdade de Associação e Direito à Negociação Coletiva

5. Discriminação

6. Práticas Disciplinares 
7. Horário de Trabalho

8. Remuneração

9. Sistemas de Gestão

(SA 8000 2001, pp. 3-8).

\subsubsection{Atuação Responsável}

Criado no Canadá, pela Canadian Chemical Producers Association - CCPA, e atualmente encontrado em mais de 40 países com indústria química em operação, o Responsible Care se propõe a ser um instrumento eficaz para o direcionamento do gerenciamento ambiental. Esse, considerado no seu aspecto mais amplo, inclui a segurança das instalações, processos e produtos e a preservação da saúde ocupacional dos trabalhadores, além da proteção ao meio ambiente por parte das empresas do setor e ao longo da cadeia produtiva.

Concebido a partir da visão do diálogo e melhoria contínua, o programa se estrutura de forma lógica, procurando fornecer mecanismos que permitam o desenvolvimento de sistemas e metodologias adequadas para cada etapa do gerenciamento ambiental que o setor persegue. O modelo criado é flexível, o que possibilita atender às necessidades de cada empresa, sem que, no entanto, perca-se a característica de um programa de toda uma indústria, quer esteja ela situada no Brasil ou em outra parte qualquer do mundo.

\subsubsection{Elementos Básicos}

A estrutura de processos de Responsible Care deve contemplar alguns elementos fundamentais que representam os principais aspectos da iniciativa:

- Um comprometimento formal das empresas com uma série de Princípios Diretivos do Processo, o que é feito através da assinatura de um "Termo de Adesão" junto à Associação Nacional da Indústria Química.

- Adoção de um nome e um logotipo que claramente identifiquem as iniciativas nacionais como consistentes com os conceitos do Responsible Care. 
- Uma série de códigos de práticas gerenciais, guias e check list destinados a ajudar as empresas a implementarem o programa internamente.

- Um processo contínuo de diálogo, sobre os assuntos ligados à saúde ocupacional, segurança e meio ambiente, com as partes interessadas.

- Indicações de como melhor encorajar para que todas as empresas filiadas à associação se comprometam e participem do Responsible Care.

- Existência de fóruns nos quais as empresas possam apresentar suas próprias visões e trocar experiências sobre a implementação do processo.

- O desenvolvimento progressivo de indicadores, através dos quais as melhorias de desempenho possam ser medidas.

- O estabelecimento de sistemáticas de verificação de progresso, adaptadas às necessidades de cada iniciativa nacional.

Os elementos básicos, aplicados coerentemente, fazem com que o programa seja eficaz. As empresas não apenas se comprometem com uma série de princípios diretivos em saúde, segurança e meio ambiente, mas também trabalham com a sua associação para direcionar a implementação dos princípios (Abiquim 2003).

\subsubsection{Matriz de Programas Saúde, Meio Ambiente e Segurança do Trabalho}

A matriz proposta por West, 1995 estabelece a avaliação das operações de risco e complexidade da organização, Figura 10. 


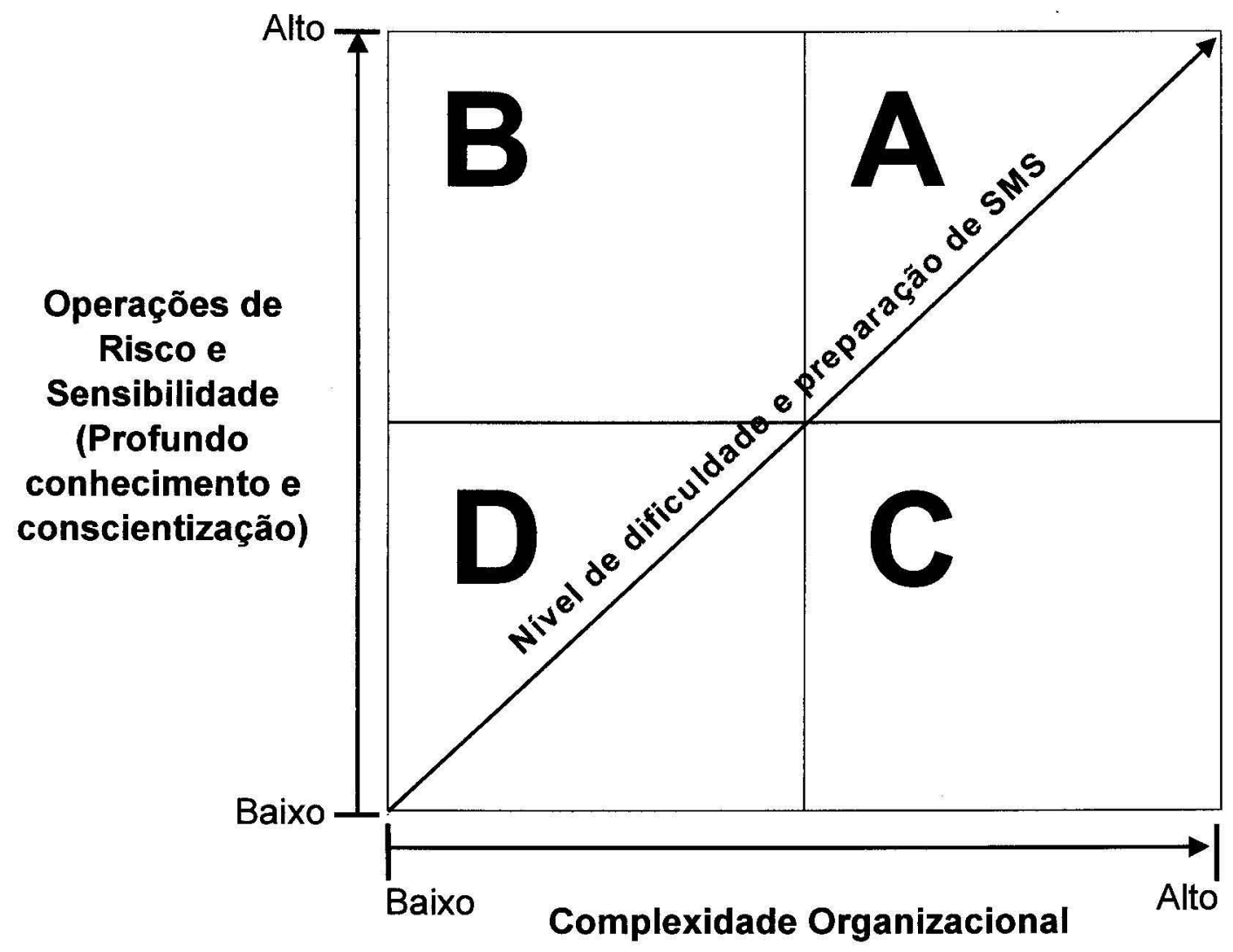

Figura 10 - Matriz de Programas de Saúde, Meio Ambiente e Segurança do

\section{Trabalho}

Fonte: West (1995, p. 13)

Operações de Risco e Sensibilidade

- Sensibilidade do mercado.

- Sensibilidade das partes interessadas (Stakeholders).

- Riscos e impactos de materiais.

- Riscos de operação e capital sobre segurança, saúde e meio ambiente.

- Histórico de problemas.

Complexidade Organizacional

- Número e diversidade de negócios.

- Operações globalizadas.

- Unidades autônomas de negócios.

- Número e diversidade de habilidades.

- Aquisição de programas. 
- QUADRANTE A : Empresas com negócios diversificados e globalizados.

Produtos e operações com impacto ambiental significativo.

Os programas de segurança, saúde e meio ambiente afetam valores dos Stakeholders.

Os programas requerem elevados custos.

A equipe de segurança, saúde e meio ambiente é preparada para dar suporte amplo aos negócios.

- QUADRANTE B : Empresas com negócios não diversificados e não globalizados.

Empresas pequenas, médias ou grandes.

Produtos e operações com impacto ambiental significativo.

O desempenho de programas de segurança, saúde e meio ambiente afetam os níveis hierárquicos.

Os programas requerem elevados níveis de responsabilidade e envolvimento, podem ser mais centralizados e ajustados com menos tecnologia do que as empresas do Quadrante A.

- QUADRANTE C : Empresas com negócios diversificados e globalizados.

Produtos e operações com mínimo impacto sobre a saúde e o meio ambiente.

Os problemas de segurança, saúde e meio ambiente afetam as pessoas em geral. Problemas tais como: asbesto, qualidade do ar de ambientes internos, doenças por esforços repetitivos podem tornar-se sérios para $o$ negócio, a menos que sejam eliminados do ambiente. As empresas do Quadrante C necessitam evitar tais problemas sem ter custos desnecessários. 
- QUADRANTE D : Empresas com pequenas dificuldades e com pequenos impactos sobre o meio ambiente.

Os programas e estratégias dos sistemas de gestão de segurança, saúde e meio ambiente representam as práticas das empresas para reduzir os custos, riscos e melhorar os valores dos Stakeholders.

Estes objetivos são válidos para todos os negócios da atualidade.

\subsubsection{Elementos Principais dos Modelos de Gestão}

O Quadro 3 apresenta 8 modelos de gestão selecionados pelo pesquisador para análise comparativa dos elementos principais de cada modelo em relação ao referencial teórico da pesquisa, ou seja, ISO 14001 e OHSAS 18001.

A abrangência dos modelos obedeceu a seguinte ordem:

\begin{tabular}{|c|c|c|}
\hline Modelo & $N^{o}$ de elementos & Gestão \\
\hline FPNQ & 17 & Excelência Empresarial \\
\hline EMAS & 15 & Meio Ambiente (Padrão de Excelência) \\
\hline ICI/SHE & 14 & $\begin{array}{l}\text { Segurança, Saúde e Meio Ambiente } \\
\text { (Sistemas Integrados de Gestão) }\end{array}$ \\
\hline ISO 9001 & 13 & Qualidade \\
\hline $\mathrm{HS}(\mathrm{G}) 65$ & 13 & Segurança e Saúde Ocupacional \\
\hline ICHEME & 13 & Segurança e Saúde Ocupacional \\
\hline ISO 14001 & 12 & Meio Ambiente \\
\hline OHSAS 18001 & 12 & Segurança e Saúde Ocupacional \\
\hline
\end{tabular}

Elementos presentes em todos os modelos de gestão:

- Informação e Análise

- Gestão de Processos 
- Responsabilidade da Direção

- Realização do Produto

- Medição, Análise e Melhoria

- Melhoria Contínua

- Política

- Implementação e Operação

- Auditoria Interna

- Análise Crítica

A matriz proposta por West (Figura 10) auxilia as organizações na escolha do modelo de gestão a ser implementado. Empresas com baixa operação de risco e complexidade implementam métodos de padronização enquanto as empresas de alta complexidade e operações de risco adotam os padrões de excelência. 


\section{Quadro 3 - Elementos Principais dos Modelos de Gestão}

\begin{tabular}{|c|c|c|c|c|c|c|c|c|}
\hline \multirow{2}{*}{$\begin{array}{l}\text { Modelos de Gestäo } \\
\text { Elementos Principais }\end{array}$} & \multirow{2}{*}{$\begin{array}{c}\begin{array}{c}\text { Excelencla } \\
\text { Empresarial }\end{array} \\
\text { FPNQ } \\
\end{array}$} & \multirow{2}{*}{\begin{tabular}{|l} 
Quallidade \\
1509001 \\
\end{tabular}} & \multicolumn{2}{|c|}{ Melo Ambiente } & \multicolumn{3}{|c|}{ Seguranca e Saúde Ocupacional } & \multirow{2}{*}{\begin{tabular}{|l} 
Integrado \\
ICI/SHE \\
\end{tabular}} \\
\hline & & & EMAS & 15014001 & OHSAS 18001 & $H S(G) 65$ & ICHEME & \\
\hline 1. Liderança & $\mathrm{x}$ & - & - & - & - & - & - & - \\
\hline 2. Planejamento Estratégico & $x$ & - & - & $x$ & $x$ & $x$ & - & - \\
\hline 3. Foco no Cliente e no Mercado & $x$ & $x$ & - & - & - & - & - & - \\
\hline 4. Informações e Análise & $x$ & $x$ & $x$ & $x$ & $x$ & $x$ & $x$ & $x$ \\
\hline 5. Gestão de Pessoas & $x$ & - & - & - & - & - & - & - \\
\hline 6. Gestão de Processos & $x$ & $x$ & $x$ & $x$ & $x$ & $\mathrm{x}$ & $\mathrm{x}$ & $x$ \\
\hline 7. Resultados da Organização & $x$ & - & $x$ & - & - & - & - & - \\
\hline 8. Responsabilidade da Direção & $x$ & $x$ & $x$ & $x$ & $x$ & $x$ & $x$ & $x$ \\
\hline 9. Gestão de Recursos & - & $x$ & - & - & - & - & $\mathrm{x}$ & - \\
\hline 10. Realização do Produto & $x$ & $x$ & $x$ & $x$ & $x$ & $x$ & $\mathrm{x}$ & $x$ \\
\hline 11. Medição, Análise e Melhoria & $x$ & $x$ & $x$ & $x$ & $x$ & $\mathrm{x}$ & $x$ & $\mathrm{x}$ \\
\hline 12. Melhoria Continua & $x$ & $x$ & $x$ & $x$ & $x$ & $\mathrm{x}$ & $x$ & $\mathrm{x}$ \\
\hline 13. Avaliação de Desempenho e Divulgação Pública & - & - & $x$ & - & - & - & - & - \\
\hline 14. Garantia de Conformidade & - & - & $x$ & - & - & - & - & $x$ \\
\hline 15. Política & $x$ & $x$ & $x$ & $x$ & $x$ & $x$ & $x$ & $x$ \\
\hline 16. Avaliação dos Aspectos Ambientais & - & - & $x$ & - & - & - & - & - \\
\hline 17. Objetivos para o Sistema de Gestão & $x$ & - & $x$ & - & - & $x$ & $\mathrm{x}$ & - \\
\hline 18. Implementação e Operação & $x$ & $\mathrm{x}$ & $x$ & $x$ & $x$ & $x$ & $\mathrm{x}$ & $x$ \\
\hline 19. Auditoria Interna & $x$ & $\mathrm{x}$ & $x$ & $x$ & $x$ & $x$ & $x$ & $x$ \\
\hline 20. Análise Crítica & $x$ & $x$ & $x$ & $x$ & $x$ & $x$ & $\mathrm{x}$ & $x$ \\
\hline 21. Verificação e Ação Corretiva & - & - & - & $x$ & $x$ & - & - & - \\
\hline 22. Fatores Internos e Externos & $x$ & $\mathrm{x}$ & - & - & - & $x$ & - & - \\
\hline 23. Práticas e Procedimentos & - & - & - & - & - & - & $x$ & $x$ \\
\hline 24. Padrões & - & - & - & - & - & - & - & $x$ \\
\hline 25. Diretrizes & - & - & - & - & - & - & - & $x$ \\
\hline Número de Elementos presentes no Modelo & 17 & 13 & 15 & 12 & 12 & 13 & 13 & 14 \\
\hline
\end{tabular}




\subsection{Organismos de Normalização}

\subsubsection{International Organization for Standardization - ISO}

A atividade de normalização teve seu início em 1906, no campo de Engenharia Elétrica, com a Comissão Eletrotécnica Internacional - IEC (International Electrotechnical Commission). Em 1926 trabalhos pioneiros em outros campos levaram a IEC a se transformar na Associação Internacional de Normalização - ISA (International Standard Association). A ênfase principal dentro da ISA foi estabelecida com grande força na engenharia mecânica.

As atividades da ISA cessaram em 1942 em razão da Segunda Guerra Mundial. Passado o conflito mundial, delegados de 25 paises, em reunião especial realizada em Londres em 1946, decidiram criar uma organização internacional de normalização. A nova organização, a ISO, começou suas atividades no dia 23 de fevereiro de 1947.

Uma vez que o nome de organização poderia ser abreviado de diversas formas dependendo do idioma do país, decidiu-se pela utilização de um nome grego "isos", que significa igual. Assim, a abreviação para o nome da organização é sempre ISO em todos os países. O nome ISO não é, portanto, originário de um acróstico, ao contrário do que pensam muitas pessoas. Hoje em dia, no entanto, a sigla ISO é conhecida por International Organization of Standardization.

A missão da ISO é promover o desenvolvimento da normalização por meio de acordos globais publicados como normas internacionais. A ISO procura também relacionar as atividades no mundo com uma nova visão, de modo a facilitar as trocas internacionais de produtos e serviços, assim como a cooperação nas esferas intelectuais, científica e tecnológica. As normas devem ser baseadas em resultados consolidados da ciência, tecnologia e experiência, visando à otimização de benefícios para a comunidade.

Portanto, segundo a própria definição da ABNT "norma é um documento estabelecido por consenso e aprovado por um organismo reconhecido que fornece para o uso comum e repetitivo, regras, diretrizes ou características para atividades ou 
resultados, visando à obtenção de um grau ótimo de ordenação em um dado contexto". Secretaria do Meio Ambiente (1997, p. 9).

\subsubsection{British Standards Institution - BSI}

A BSI é um organismo independente responsável pela elaboração de normas britânicas. Representa o Reino Unido na Europa e internacionalmente. Occupational Health and Safety Assessment Series (OHSAS 18001, 1999).

\subsubsection{Council on Economic Priorities Accreditation Agency - CEPAA}

A Responsabilidade Social Internacional - SAI fundada em 1997 como CEPAA, está trabalhando para aumentar a conscientização entre os consumidores sobre as condições de trabalho ao redor do mundo. Desde 1990, um número cada vez maior de empresas têm publicado seus códigos de conduta e exercem influências sobre os fornecedores. O Instituto de Pesquisa de Responsabilidade Social realiza há 30 anos uma série de estudos sobre os códigos de conduta no ambiente de trabalho. Os estudos demonstram:

- Alta inconsistência

- Grande extensão

- Monitoramento ineficiente

- Falta de clareza

- Falta de auditores treinados

Em resposta, foi desenvolvido pela SAI um padrão para as condições de trabalho e um sistema independente para a verificação de conformidade. O Padrão Social Accountability 8000 (SA 8000) e seu sistema de verificação foi criado para o estabelecimento da estratégia do negócio, assegurar a qualidade e acrescentar elementos que especialistas em direitos humanos têm identificado como essencial para uma auditoria social. (CEPAA 2002, p. 1). 


\subsubsection{Associação Brasileira de Normas Técnicas - ABNT}

A ABNT é a representante oficial do Brasil na ISO. A ABNT é uma entidade civil, sem fins lucrativos, fundada em 28 de setembro de 1940 e considerada de utilidade pública pela Lei 4150/62. Seu objetivo é o de elaborar normas técnicas e implementar atividades afins em âmbito nacional, visando facilitar as trocas de bens e serviços bem como promover o desenvolvimento da ciência, da tecnologia, da indústria e do comércio no país.

A ABNT busca harmonizar os interesses de produtores, de consumidores ou usuários do governo e da comunidade técnico-científica, preparando suas normas por consenso. Integra o Sistema Nacional de Metrologia, Normalização e Qualidade Industrial, criado pela Lei Federal No. 5.966/73, sendo reconhecida como o único Fórum Nacional de Normalização, por força da Resolução No. 7 do Conselho Nacional de Metrologia - CONMETRO, de 24 de Agosto de 1992.

A ABNT, nos seus 57 anos de existência, sempre colaborou com o desenvolvimento tecnológico do país, uma vez que a normalização é um pressuposto básico para a melhoria da qualidade e produtividade em todas as atividades econômicas.

Em 1994, foi criado dentro da ABNT, o Grupo de Apoio à Normalização Ambiental - GANA, como resultado do esforço de algumas empresas, associações e representantes de segmentos econômicos e técnicos no país. Essa iniciativa deveu-se à percepção de alguns empresários do aumento da importância das normas ambientais internacionais na colocação de produtos junto ao mercado internacional. Esses empresários perceberam que a não adoção de normas ambientais configuraria um risco real de perda de mercados externos.

O apoio financeiro dado por mais de 30 empresas ao GANA mostra o quanto esta preocupação tornou-se presente na pauta de discussões do empresariado brasileiro.

O GANA é, portanto, constituído por profissionais representantes dos diversos setores da economia brasileira, tais como a Companhia Vale do Rio Doce, Petrobrás, Aracruz Celulose, Confederação Nacional das Indústrias, Federação das Indústrias do Estado de São Paulo (FIESP), Associação Nacional de Exportação, Instituto Brasileiro de Siderurgia - IBS, Banco Nacional de Desenvolvimento Econômico e 
Social - BNDES. Seu objetivo é acompanhar e analisar os trabalhos desenvolvidos pelo Comitê Técnico 207 da ISO, no sentido de avaliar os impactos das normas ambientais internacionais nas organizações brasileiras, procurando levar em conta a especificidade da atividade produtividade no país. A participação como se verifica, foi sobretudo por parte do setor empresarial. Poucas vezes setores governamentais ou Organizações Não Governamentais participaram efetivamente das discussões no GANA.

Pode-se afirmar, então que os trabalhos do GANA/ABNT procuram evitar que as normas estabelecidas pela série ISO 14000 acabem privilegiando práticas e tecnologias acessíveis, técnica e economicamente, apenas aos países do Primeiro Mundo. Secretaria do Meio Ambiente. (1997, p. 20).

Com o desenvolvimento da maioria das Normas da Série ISO 14000, o GANA foi extinto e deu lugar ao Comitê Brasileiro - CB-38 (Abreu 2000, p. 38).

\subsubsection{Fundação para o Prêmio Nacional da Qualidade - FPNQ}

Em Outubro de 1991, foi instituída a Fundação para o Prêmio Nacional da Qualidade - FPNQ, entidade privada e sem fins lucrativos, fundada por 39 organizações privadas e públicas para administrar o Prêmio Nacional da Qualidade PNQ e todas as atividades decorrentes do processo de premiação em todo o território nacional e fazer a representação institucional externa do PNQ nos fóruns internacionais.

O Prêmio Nacional de Qualidade estimula a melhoria da qualidade da gestão das organizações brasileiras, reconhecendo anualmente aquelas que atingiram o nível de desempenho de "classe mundial", ou seja, organizações que são destacadas pela excelência da gestão de suas práticas e respectivos resultados, promovendo interna $\mathrm{e}$ externamente a reputação de excelência dos produtos e serviços brasileiros, divulgando as práticas exemplares de gestão e, conseqüentemente, contribuindo para a melhoria da qualidade de vida do povo brasileiro. FPNQ $(2002$, p. 5). 


\subsection{Planejamento e Implementação de Sistemas de Gestão}

O planejamento e implementação de um sistema de gestão são, na realidade, a aplicação de conceitos e técnicas de administração. Neste trabalho, preferiu-se utilizar as ferramentas empregadas em qualidade associadas a conceitos e requisitos estabelecidos nas normas internacionais mais aceitas no assunto de Gerenciamento em Segurança, Saúde e Meio Ambiente, que são as Normas OHSAS 18001 e ABNT NBR ISO 14001.

A implementação deverá ser feita cumprindo-se, basicamente, três grandes conjuntos de atividades:

a) Análise da situação atual da empresa

Verificar "onde estamos" no momento, no tocante ao desempenho atual da empresa quanto aos seus produtos, serviços prestados e sistemas de produção.

b) Estabelecimento de metas

Estudar as possibilidades fisicas, materiais, recursos disponíveis e interesses da empresa expressos em sua política para definir "onde queremos chegar".

c) Estabelecimento de métodos

A palavra método tem sua origem grega e significa "caminho para se alcançar a meta", ou seja, o estabelecimento de métodos vai definir "como chegar".

A ferramenta que consideramos mais importante e que poderá resumir toda a implementação do processo do SGA é o ciclo PDCA, também conhecido como Ciclo de Deming, composto por quatro grandes passos de PLAN (planejar); $D O$ (realizar); $C H E C K$ (verificar); e $A C T$ (atuar para corrigir) e recomeçar um novo ciclo. Esse ciclo deve ser precedido por uma atividade de "Estabelecimento da Política Ambiental" da empresa. O ciclo PDCA está representado na Figura 11 (Moura 2000). 


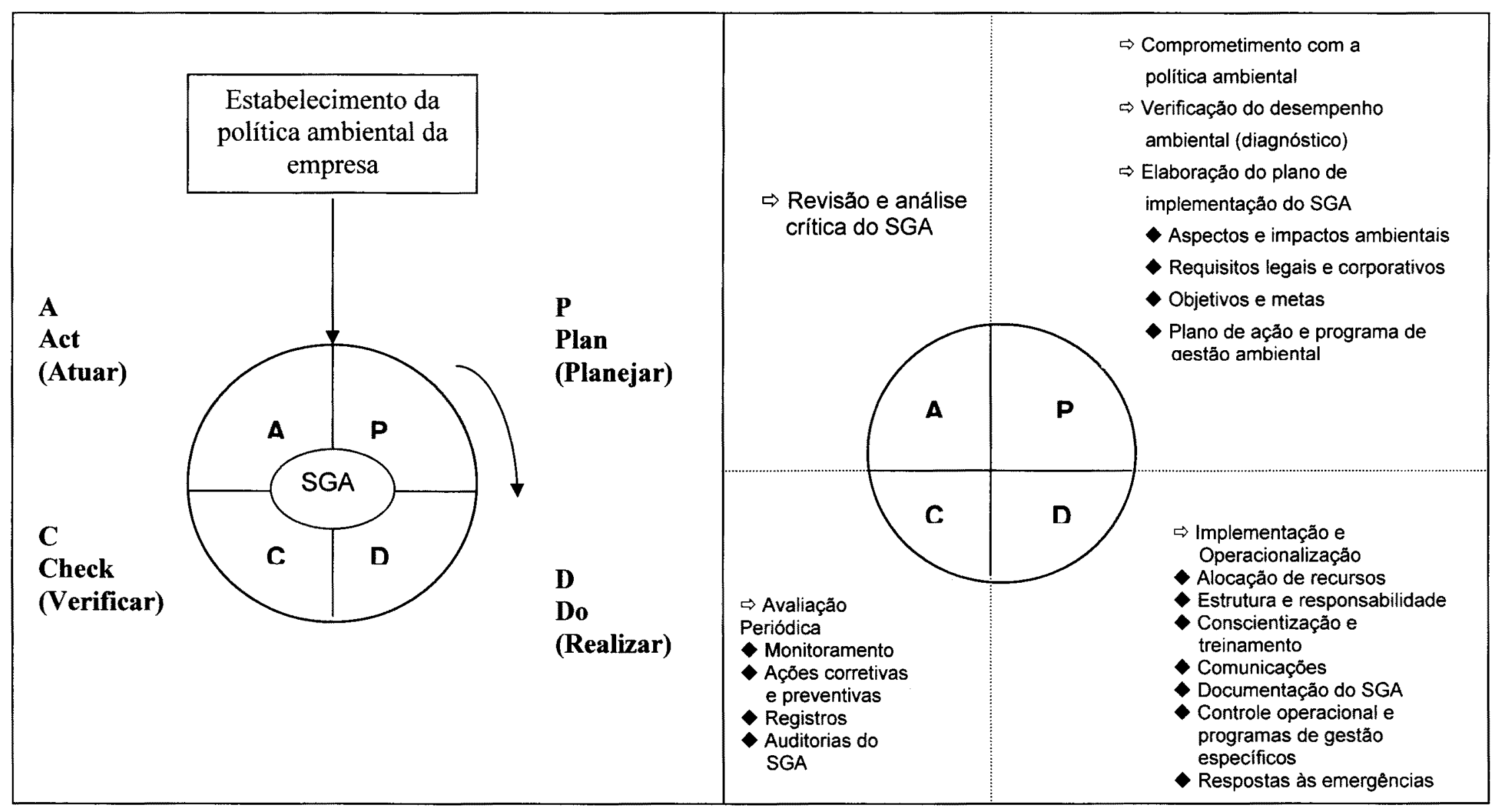

Figura 11 - Ciclo PDCA do Sistema de Gestão Ambiental

Fonte: Moura (2000, p. 60) 


\subsubsection{Como Implementar um Sistema de Gestão Ambiental}

A International Organization for Standardization desenvolveu para o Padrão ISO 14001 a Estrutura de Trabalho da Figura 12 que conforme a Public Entity Environmental Management System Resource Center - PEERCENTER serve para definir em quais áreas ou operações será aplicado o SGA.

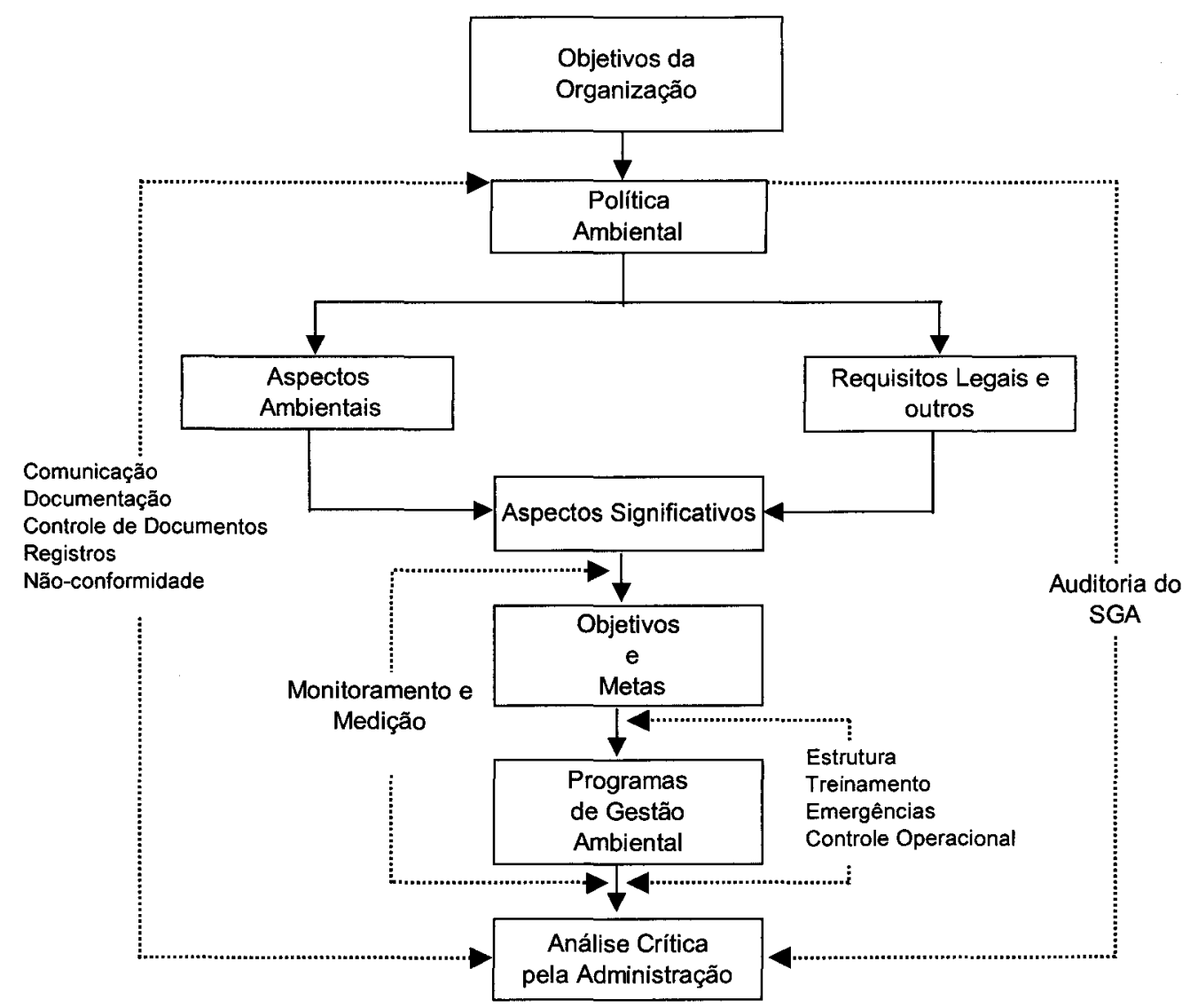

Figura 12 - Estrutura de Trabalho da ISO 14001

Fonte: www.peercenter.net/whatisems.cfm [2002 Agosto 02]

A Peercenter é um órgão público do governo americano que ajuda as organizações na implementação dos sistemas de gestão ambiental, através de informações, consultoria, diretrizes e treinamento. A Peercenter sugere um prazo de dois anos para a implementação do SGA. 
As diretrizes testadas em campo, ferramentas de implementação, amostras de documentos verificadas, foram baseadas no aprendizado, beneficios, barreiras e chaves para o sucesso de vinte e três (23) empresas participantes.

As razões para a implementação do SGA podem incluir:

- Desenvolvimento de uma estrutura de gestão ambiental para atender as necessidades da organização.

- Melhoria operacional.

- Mudança da cultura operacional.

- Melhoria da imagem pública.

- Melhoria nas relações com órgãos regulamentadores.

- Acrescentar capacidade intelectual para encontrar requisitos regulamentares.

- Maior conscientização e comprometimento dos funcionários para o desempenho ambiental da empresa.

A empresa quando decide implementar um Sistema de Gestão Ambiental deve:

- Definir quais áreas ou operações.

- Considerar as atividades, produtos ou serviços controlados pela empresa.

- Selecionar uma operação ou departamento como piloto.

O conhecimento adquirido, chaves para o sucesso e as boas práticas é aplicado na medida em que cresce o escopo para outras operações da organização.

Peercenter : www.peercenter.net/howtoimplement [2002 Agosto 02]

\subsubsection{Planejamento Pró-Ativo de SSO}

Ao invés do ciclo PDCA, a British Standards utiliza a metodologia para o planejamento e implementação de sistemas de gestão de SSO conforme apresentado na Figura 13.

O planejamento de SSO requer uma abordagem que ressalta a prevenção. Os sistemas pró-ativos de gerenciamento de SSO deverão promover a melhoria contínua e assegurar que: 
- Dispositivos apropriados estejam disponíveis, com recursos adequados, com pessoal competente e com responsabilidades definidas e que incorporem canais eficazes de comunicação.

- Os procedimentos sejam adotados para estabelecer objetivos, conceber e implementar planos, visando atender aos objetivos e monitorar tanto a implementação quanto a eficácia dos planos.

- Os perigos sejam identificados e os riscos avaliados e controlados antes que alguém (ou qualquer coisa) seja adversamente afetado.

- O desempenho de SSO seja medido com uma gama de técnicas e que uma ausência de eventos perigosos não seja vista como evidência conclusiva de que tudo está bem.

Uma parte vital do planejamento pró-ativo de SSO é o gerenciamento das mudanças. As que podem afetar a SSO incluem:

- Mudança no pessoal.

- Propostas de novos produtos, nova fábrica, novos processos ou serviços.

- Mudanças nos procedimentos de trabalho.

- Modificações de processos.

- Modificações de software.

As mudanças externas que, entre outras, podem afetar a SSO, incluem:

- Nova legislação.

- Desenvolvimento no conhecimento e tecnologia de SSO.

A Figura 13 demonstra o planejamento e implementação de SSO na prática (BS 8800 1996). 


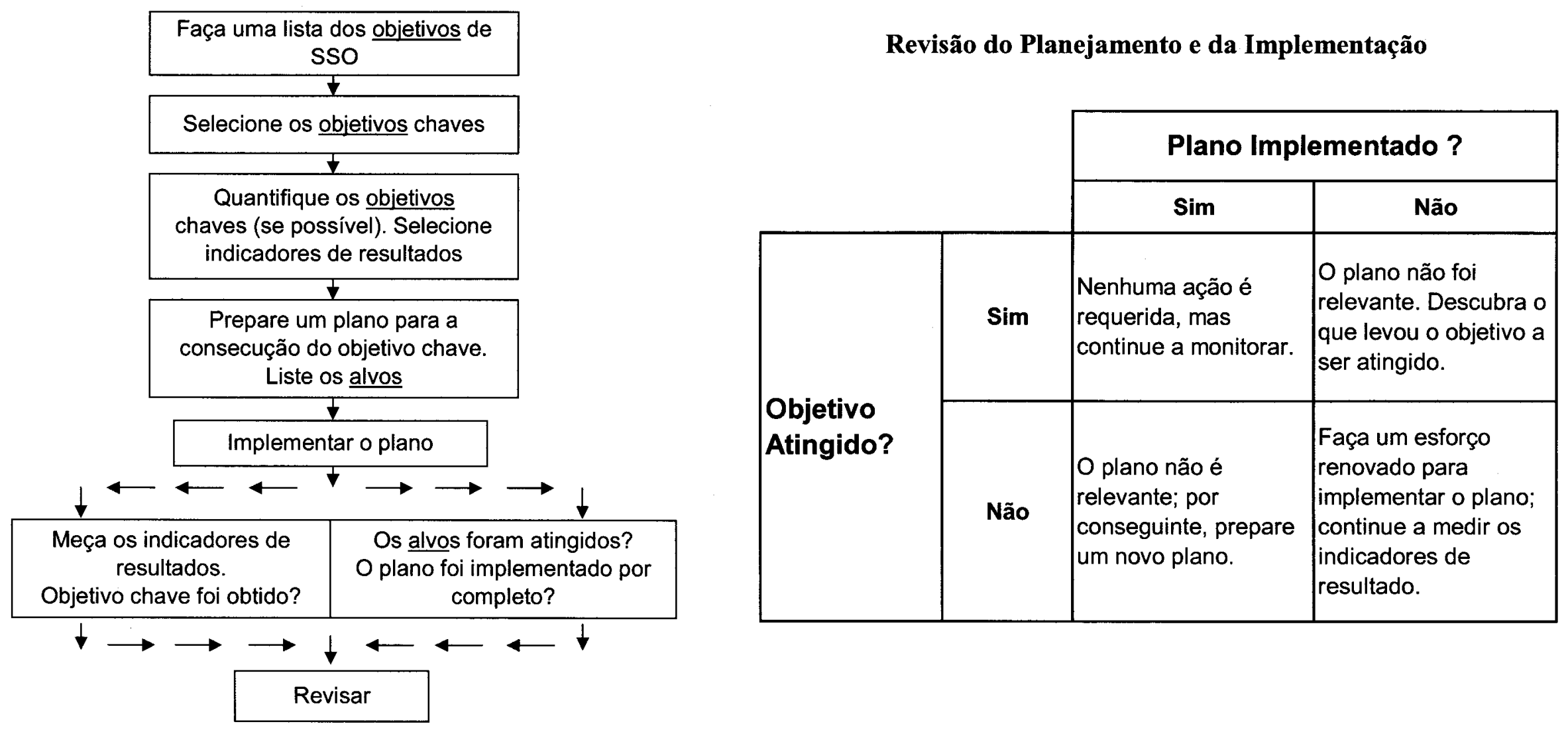

Figura 13 - Planejamento e Implementação de SSO na Prática

Fonte: BS 8800 (1996, pp. 29 e 36) 


\subsubsection{Diagnóstico e Planejamento Estratégico da Organização}

A decisão da implementação de um sistema de gestão depende do diagnóstico e planejamento estratégico da organização. O diagnóstico estratégico proposto por Almeida - "Planejamento Empresarial - Uma Visão Integrada" citado por Moura $(2000$, p. 72$)$ permite uma escolha consciente, entre as opções possíveis, do rumo a ser adotado pela empresa e uma visualização das ações a serem tomadas (Quadro 4).

A análise de dados é feita utilizando-se a Técnica SWOT (Strong, Weak, Opportunities, Threats) e sempre que possível, deve-se comentar a situação das empresas concorrentes, comparando-se resultados com aqueles equivalentes da empresa.

O planejamento estratégico de longo prazo inicia-se com os objetivos corporativos e a declaração da missão da empresa seguida pelos objetivos estratégicos e os métodos de implementação, por exemplo:

\section{Objetivo Corporativo:}

"Controlar e manter as vantagens competitivas para maximizar os valores da Companhia".

\section{Missão do Departamento:}

"Prover diretrizes corporativas e assegurar esforços para a melhoria da qualidade de vida das gerações atuais e futuras através da proteção da saúde humana, do meio ambiente e da segurança de todas as atividades". 
Quadro 4 - Diagnóstico Estratégico da Organização

\begin{tabular}{|c|c|c|c|}
\hline \multirow{2}{*}{\multicolumn{2}{|c|}{$\begin{array}{l}\text { DIAGNÓSTICO } \\
\text { ESTRATÉGICO }\end{array}$}} & \multicolumn{2}{|c|}{ Análise do Ambiente Interno } \\
\hline & & $\begin{array}{l}\text { Predominância de } \\
\text { VULNERABILIDADES }\end{array}$ & $\begin{array}{l}\text { Predominância de } \\
\text { POTENCIALIDADES }\end{array}$ \\
\hline \multirow{2}{*}{$\begin{array}{l}\text { Análise } \\
\text { do } \\
\text { Ambiente } \\
\text { Externo }\end{array}$} & $\begin{array}{l}\text { Predominância } \\
\text { de } \\
\text { AMEAÇAS }\end{array}$ & $\begin{aligned} & \text { SOBREVIVÊNCIA: } \\
\text { - } & \text { Redução de custos } \\
\text { - } & \text { Redução de investimentos } \\
\text { - } & \text { Liquidação da empresa }\end{aligned}$ & $\begin{aligned} & \text { MANUTENÇÃO: } \\
& \text { - Estabilidade } \\
& \text { - } \text { Ocupação do nicho } \\
& \text { - Especialização }\end{aligned}$ \\
\hline & $\begin{array}{l}\text { Predominância } \\
\text { de } \\
\text { OPORTUNIDADES }\end{array}$ & $\begin{aligned} & \text { CRESCIMENTO: } \\
\text { - } & \text { Inovação } \\
\text { - } & \text { Internacionalização } \\
\text { - } & \text { Joint ventures } \\
\text { - } & \text { Aumento de investimento }\end{aligned}$ & $\begin{array}{l}\text { DESENVOLVIMENTO: } \\
\text { - Desenvolvimento de: } \\
\text { - produtos } \\
\text { - mercados } \\
\text { - capacidades } \\
\text { - Diversificação: } \\
\text { - vertical } \\
\text { - externa } \\
\text { - interna }\end{array}$ \\
\hline
\end{tabular}

Fonte: Almeida, Sérvio - "Planejamento Empresarial - Uma Visão Integrada" citado por Moura (2000, p. 72) 


\section{Objetivos Estratégicos:}

1. Melhoria contínua na proteção de saúde, meio ambiente e segurança do trabalho e nos benefícios oferecidos pela empresa.

2. Gestão das atividades em conformidade com os requisitos da companhia, legais, estatutários e regulamentares.

3. Identificação e suporte para a integração da saúde, meio ambiente, segurança do trabalho, gerenciamento de riscos, plano de negócios e gestão de processos da empresa.

\section{Métodos para atingir os objetivos:}

1. Comunicação e avaliação das expectativas da empresa sobre a proteção humana e do meio ambiente, em todos os níveis da organização e das partes interessadas.

2. Identificar como o sistema de gestão de saúde, meio ambiente e segurança do trabalho contribuem para o plano de negócios, gestão de processos e programas da companhia.

3. Prover direção para a integração do gerenciamento nas funções e níveis de saúde, meio ambiente, segurança do trabalho e gerenciamento de risco.

4. Medir a contribuição do sistema de gestão em saúde, meio ambiente e segurança do trabalho para o negócio da empresa.

A Figura 14 apresenta os aspectos chaves de planejamento e implementação dos sistemas de gestão de saúde, meio ambiente e segurança do trabalho. 


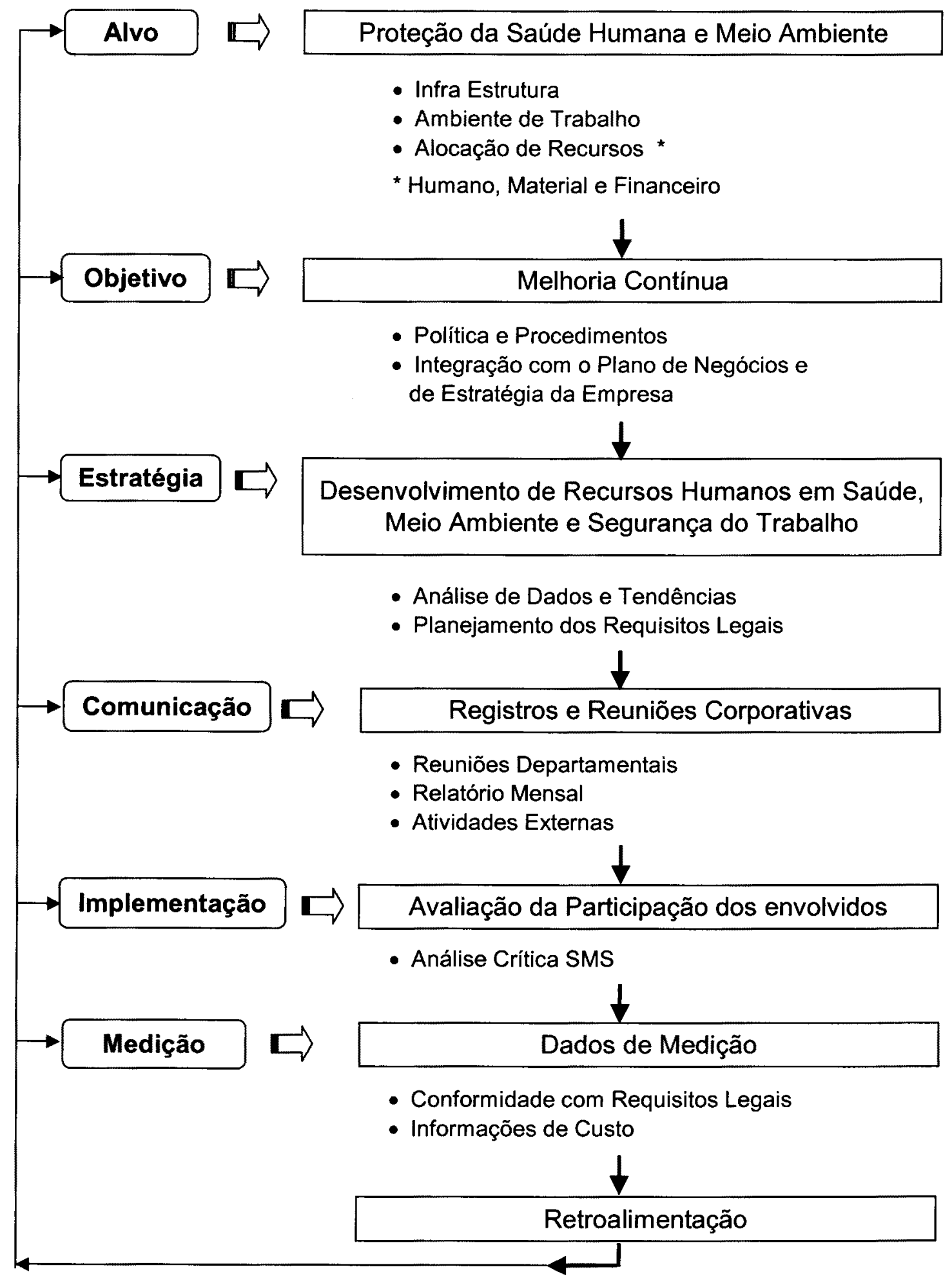

Figura 14 - Planejamento e Implementação SMS

Fonte: Friedman (1995, p. 104) 


\subsection{Sistemas Integrados de Gestão - SIG}

Para entender como as empresas estão organizadas e quais as mudanças a serem feitas através dos sistemas de gestão SMS foram analisados por West os programas das sete maiores corporações com negócios nas áreas de: aeroespacial, química, automotiva, óleo, papel, produtos de madeira, farmacêutica, produtos e serviços de telecomunicações. Suas operações e produtos têm impacto potencial e significativo em segurança, saúde e meio ambiente.

O foco envolve três questões básicas:

1. Qual é o envolvimento do alto executivo da empresa no sistema de gestão de segurança, saúde e meio ambiente?

2. Como é feito o desenvolvimento de funcionários e alocação de recursos pela companhia, pelas unidades de negócios e pelos níveis hierárquicos para o desempenho de funções no sistema de gestão de segurança, saúde e meio ambiente?

3. Qual a formação do pessoal de segurança, saúde e meio ambiente; como são treinadas, e qual a extensão de intercâmbio com outras unidades da empresa? West (1995, p. 50).

O desenvolvimento em proteção ambiental caminha paralelamente com a saúde, segurança e prevenção de perdas. Esses aspectos no projeto e operações de plantas industriais têm muito em comum. Recentemente, tem sido uma tendência designar uma única pessoa como responsável. Há algumas situações em que existe um conflito potencial. Less (1996, p. 12).

O Triângulo da Inovação proposto por Dijken e Col (1999, p. 14) distingue três (3) fatores principais (Figura 15):

- Competência empresarial (diferenciada entre motivação, conhecimento e poder).

- Desenvolvimento sustentável (reconhecer a gestão do ambiente como um das principais prioridades na empresa, estabelecer políticas, programas próativos, que vão além da conformidade legal e procedimentos para conduzir as atividades de modo ambientalmente seguro). 
- Envolvimento da força de trabalho (depende do tamanho e das atividades desenvolvidas pela força de trabalho).

\section{Competência Empresarial}

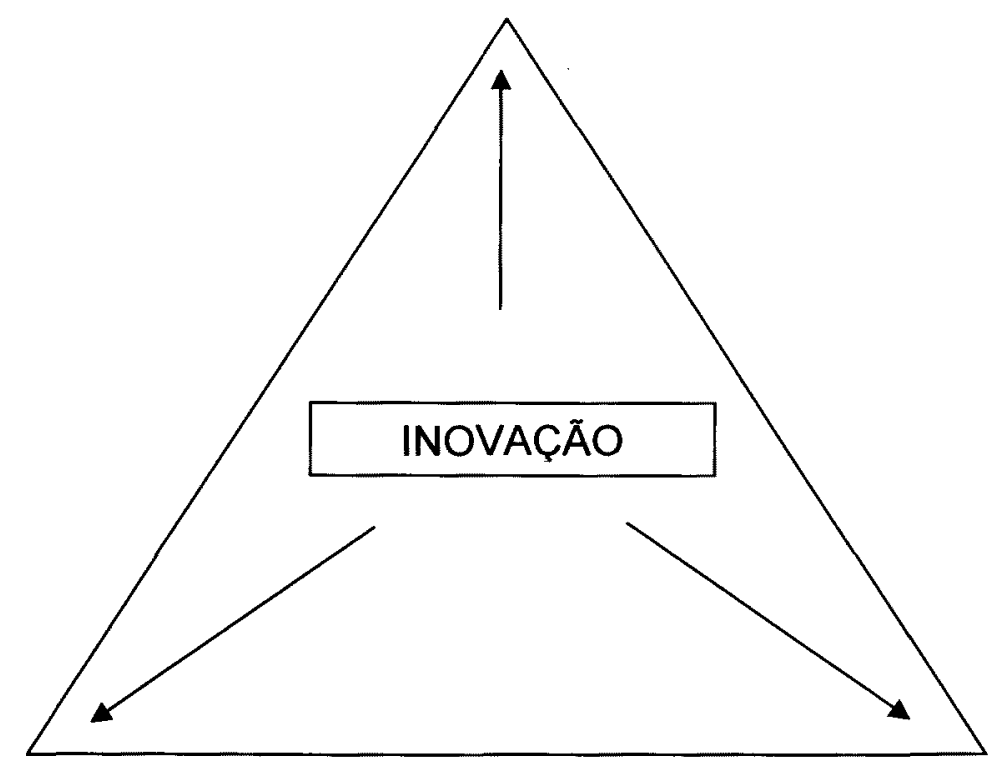

Desenvolvimento

Sustentável

Força de

Trabalho

\section{Figura 15 - O Triângulo da Inovação}

Fonte: (....) Adaptação; Dijken, Prince, Wolters, Frey, Mussati, Kalff, et. al. $(1999$, p. 14)

A carta empresarial para desenvolvimento sustentável da Câmara de Comércio Internacional - CCI estabelece:

- Gestão Integrada - Segundo parágrafo.

Integrar plenamente, em cada empresa, políticas, programas e procedimentos, como elemento essencial de gestão, em todos os domínios ABNT NBR 14004 (1996, p. 30).

- Cumprimento de regulamentos e informações - Décimo sexto parágrafo.

Aferir o desempenho das ações sobre segurança, saúde e meio ambiente, proceder regularmente as auditorias e avaliar o cumprimento das exigências internas 
da empresa, dos requisitos legais e dos princípios de desenvolvimento sustentável e periodicamente fornecer as informações pertinentes ao Conselho de Administração, aos acionistas, ao pessoal, às autoridades e ao público.

Uma importante diferença quando os sistemas de gestão são integrados deve ser o redirecionamento de esforços de um elemento normativo para a orientação de processos, pois qualquer mudança na organização é muito complexa.

A falta de integração da equipe no desenvolvimento e implementação do SIG aumenta a resistência a mudanças, dificulta as ações de gestão e boas metodologias deixam de ser empregadas.

O SIG deve atender as seguintes exigências:

- Estrutura clara.

- Ponto de partida para a melhoria contínua.

- Aumento na eficiência e produtividade.

- Possibilidade de certificação.

- Uso de sinergia durante a integração.

- Fácil execução do sistema, mesmo para funcionários não treinados.

- Consideração de características individuais das empresas.

Os pontos essenciais a serem observados durante a introdução do SIG:

- Os funcionários devem ter o domínio sobre os procedimentos da empresa.

- O SIG não deve aumentar a burocracia do dia a dia de trabalho.

- Poucos funcionários são treinados para interpretação, conhecimento do padrão normativo e de requisitos legais.

- As mudanças devem ter relevância prática.

- A alta direção deve criar espaço para os funcionários desenvolverem projetos de trabalho.

- Definição clara de responsabilidades. 
O modelo de SIG proposto por Mackau é baseado em um manual que compreende cinco capítulos, a saber:

\section{Capítulo 1: A Organização \& Gerenciamento de Projeto}

- Declaração de regras e competências.

- Criação e controle de documentos.

- Explicação da estrutura da organização.

- Recursos humanos.

\section{Capítulo 2: Produtos e Serviços}

- Requisitos específicos ou processos de manufatura são definidos por exigência de requisitos legais, de clientes e da organização.

\section{Capítulo 3: Gerenciamento de Processos}

- Visualização de todos os processos da organização. O modelo de processo foi desenvolvido em processos principais e auxiliares, assumindo que o processo principal existe em toda organização e o processo auxiliar pode ser identificado, mas não tem que existir naquela linha de negócios.

\section{Capítulo 4: Clientes e Fornecedores}

- O envolvimento de fornecedores é necessário para o SIG, entretanto ditar regras e avaliá-los é uma tarefa difícil.

\section{Capítulo 5: Melhoria Contínua e Benchmarking}

O Benchmarking não faz parte dos requisitos normativos, porém avalia o desempenho e discute a solução de problemas entre as organizações da mesma linha de produtos.

A aproximação também contribui para a troca de experiência e para a classificação do SIG.

Os cinco capítulos são interligados com subcapítulos e as ferramentas de gestão do Total Quality Management - TQM são consideradas. Para efeito de certificação 
do SIG, os requisitos normativos são também incluídos nos capítulos do manual e, portanto, cada empreendimento tem a oportunidade de criar um modelo de acordo com as necessidades individuais e requisitos (Mackau 2003).

Entretanto, com sistemas de gestão da qualidade e SMS em separado é difícil conseguir um alinhamento comum de objetivos para a organização, pois dividem os recursos, confundem os funcionários e ainda apresentam os seguintes problemas:

- Criam esforços redundantes e são ineficientes.

- São burocráticos e não ajudam o processo, na percepção de gerentes e da força de trabalho.

- Ficam restritos aos profissionais de qualidade e SMS porque o enfoque é maior na conformidade do que nos sistemas.

- As organizações podem atender aos requisitos legais e ainda assim ter falhas catastróficas (Knode and Albernathy 2000).

O Centro de Qualidade, Segurança e Produtividade para o Brasil e América Latina - QSP realizou, em março de 2003, uma pesquisa com empresas certificadas pela NBR-ISO 14001 e OHSAS 18001/BS 8800 no Brasil sobre SIG e obteve o seguinte resultado:

- $61,2 \%$ das empresas que tomaram parte da pesquisa informaram que seus sistemas estão integrados e o restante $38,8 \%$ possuem sistemas independentes. 
A evolução normativa dos sistemas de gestão está representada pela Figura 16.

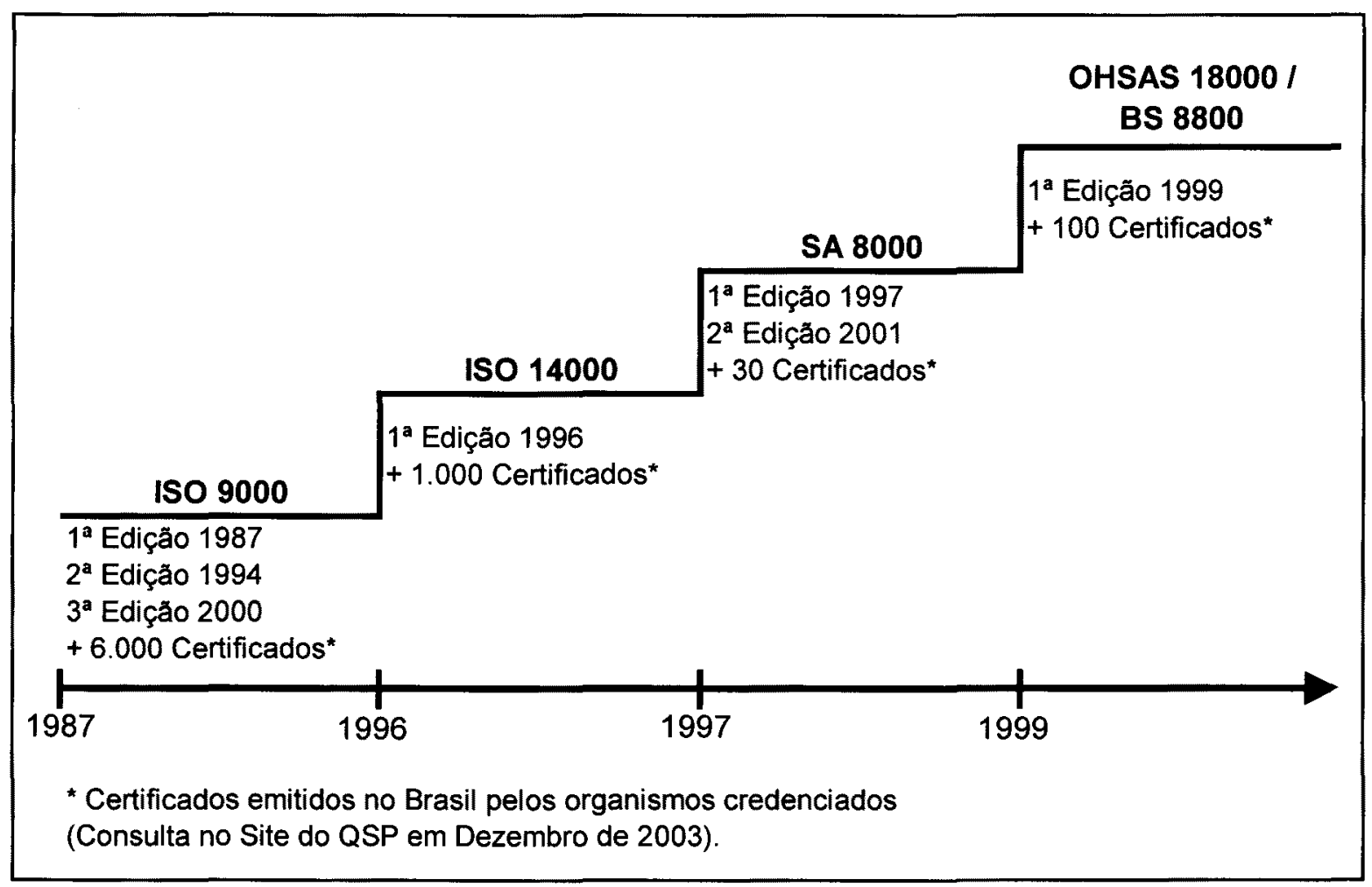

Figura 16 - A Evolução Normativa dos Sistemas de Gestão

O que observamos no mercado sobre os SIG é o uso do sistema de gestão da qualidade como alicerce e a partir daí é feita a migração e extensão dos requisitos normativos dos outros sistemas de gestão, porém o modelo da ISO 14000 e o da OHSAS 18000 por serem idênticos, é o que permite maior grau de aderência e simplificação na integração da documentação.

As dificuldades na integração do SIG não são os documentos normativos, atendimento à legislação ou registros de conformidades, mas, sim, as resistências às mudanças, capacitação técnica da equipe de SMS, conflitos de interesses entre departamentos, o aprendizado do trabalho em equipe e a multidisciplinaridade.

O sucesso das organizações na atuação em SMS é medido em relação a critérios predeterminados. Isso revela quando e onde a ação corretiva é necessária para a melhoria do sistema. A execução de auditorias de SMS em organizações é reconhecida agora como um componente essencial para o êxito dos sistemas de gestão SMS. A auditoria tem valor como parte de um sistema de gestão como um todo, e não como um substituto dele, devendo ser dirigida de forma sistemática, 
imaginativa e aplicada. O check list utilizado na auditoria é somente um de diversos fatores que determina o valor final da auditoria. A competência dos auditores, suas percepções das organizações que estão sujeitas ao exame detalhado, sua independência e o processo de retroalimentação e tomada de decisão, que apóiam as organizações para examinar e mudar o caminho em que elas operam, são igualmente importantes (Lindsay, FD 1992).

O Board of Environmental, Health \& Safety Auditor Certifications - BEAC é um empreendimento conjunto do Institute of Internal Auditors - IIA e do Environmental Auditing Roundtable - EAR, o qual foi estabelecido em 1997 nos Estados Unidos da América, a fim de fornecer programas de certificação para a prática profissional de auditoria de saúde, meio ambiente e segurança do trabalho. Em 1998, o BEAC criou um comitê técnico chamado BEAC Standards Board, com o objetivo de desenvolver e adotar normas sobre auditoria de SMS, de forma a fornecer subsídios aos programas de certificação do BEAC. A partir disso, em 1999, o BEAC Standards Board publicou a primeira codificação das "Standards for the Professional Practice of Environmental, Health and Safety Auditing", no qual o termo auditoria de SMS é definido como sendo um processo sistemático e documentado de coletar e avaliar objetivamente a informação factual para verificar as condições de SMS de um local da organização com respeito a critérios específicos e predeterminados. (BEAC, p. 42) citado por (Silva 2002).

A auditoria é apenas um requisito do sistema de gestão, mas deve receber atenção como um meio de reduzir as inspeções dos órgãos de fiscalização e assegurar a conformidade legal (Friedman 1995, p. 133).

Existe um conflito crescente entre o pessoal da companhia com responsabilidades pela auditoria e empresas de consultoria. Há uma percepção entre o público e alguns legisladores de que a auditoria não é "independente" a menos que seja realizada por profissional especializado que não pertença à organização.

Uma sugestão é o estabelecimento de um programa de certificação pública de auditores e a criação da agência de avaliação tecnológica. Os auditores atestam publicamente a qualidade da planta e a transparência dos dados e registros (Friedman 1995, pp. 136-137). 


\subsubsection{Auditoria Integrada}

O modelo de auditoria integrada é utilizado pela Dow e discutido por Less (1996, p. 32). A empresa define quais são os requisitos mínimos a serem auditados por especialistas.

O sistema de auditoria foi construído em diversos níveis (Figura 17), integrando a segurança, saúde e meio ambiente entre outras. É importante reconhecer que o sistema funciona somente se os níveis inferiores da auditoria forem atuantes, então uma parte importante da auditoria integrada é a verificação das auditorias internas e dos controles de gerenciamento do sistema de auditoria.

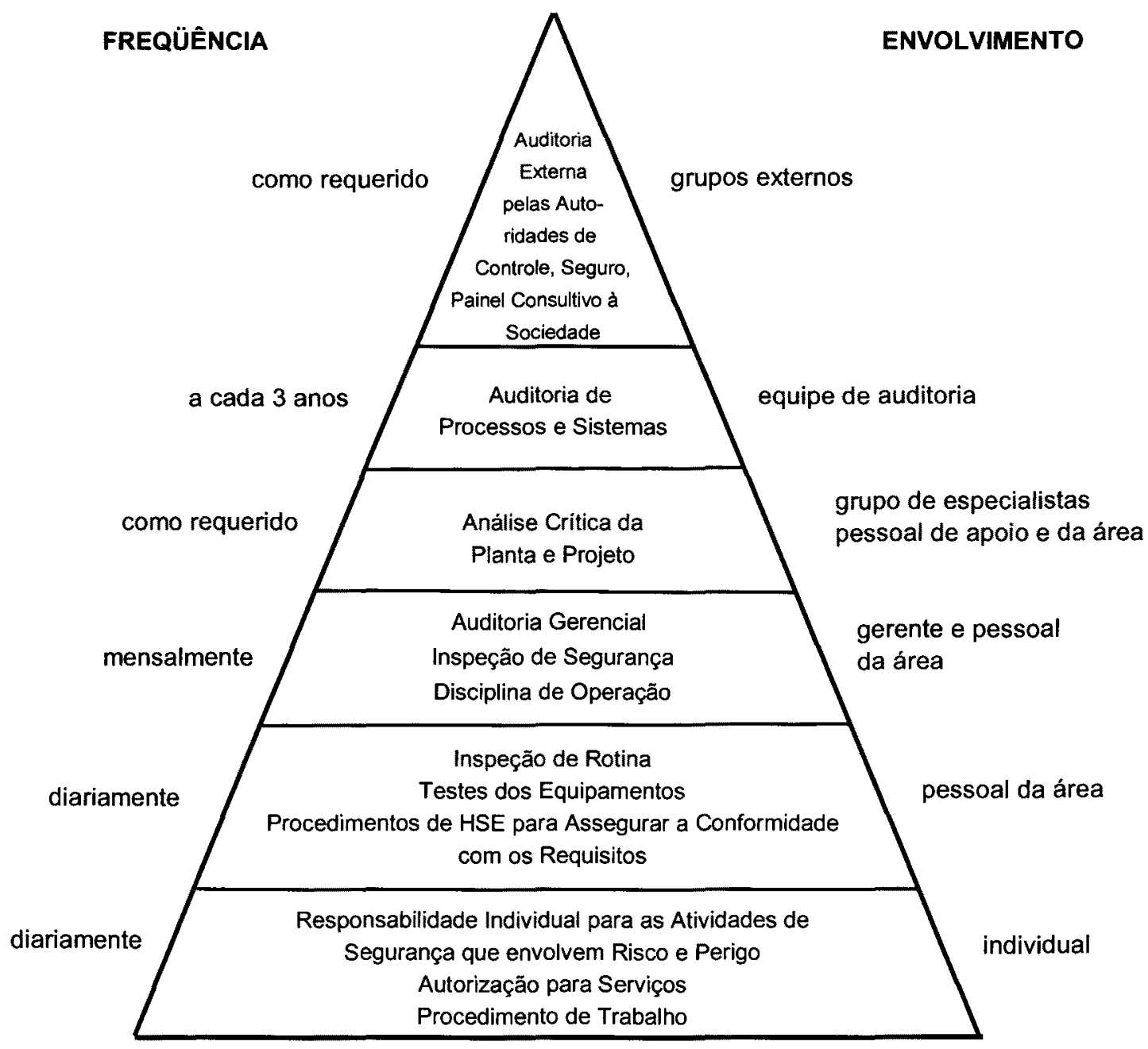

Figura 17 - Níveis de Auditoria

Fonte: ICHEME (1994, p. 33) 


\subsubsection{Protocolo de Auditoria}

A auditoria integrada é realizada através de um ciclo de três anos e consiste de uma fase de preparação e outra de avaliação de campo.

A fase de preparação é descrita a seguir:

- Questionários baseados nos requisitos mínimos da empresa são emitidos pelo gerente da planta a ser auditada, em conjunto com especialistas (segurança, saúde, meio ambiente, etc.).

- O protocolo de auditoria requer evidências na forma de estatísticas, registros e estágios de programas adotados pela empresa.

- Os registros e o questionário são encaminhados para o coordenador que distribui cópias para a equipe de auditores composta por especialista sênior e gerentes de cada área.

- Cada auditor deve estudar o material antes da instalação da seção plenária.

- O objeto da auditoria é usualmente uma unidade de operação. Em alguns casos, pode haver auditorias separadas em várias unidades de operação da planta durante o ciclo de três anos de auditoria.

A fase de avaliação de campo normalmente demora dois dias e consiste das seguintes etapas:

- Seção plenária com a equipe de auditores onde são explicados os processos de operação da planta e as diretrizes da auditoria.

- Inspeção da planta e observações são registradas para o relatório final.

- Cada área é examinada através de evidências das atividades e/ou registros.

- O questionário é analisado criticamente e as respostas são validadas no documento.

- Os auditores são livres para inspecionar qualquer aspecto da planta em qualquer momento.

- Entrevistas são feitas com o pessoal de operação para assegurar que o sistema está implementado.

- O processo é repetido para cada área até completar todas as unidades. 
Resumo em sessão plenária:

- Os auditores avaliam o sistema de gestão e a conformidade com os requisitos, diretrizes para o uso e procedimentos.

- No final da sessão plenária, o resultado é registrado na forma de:

- Um resumo de desempenho em relação aos requisitos.

- Uma lista de tarefas acordadas entre as partes.

- Responsabilidades, prazos e acompanhamento.

O relatório final contém o material preparado para a atividade de acompanhamento e a base de documentos para o próximo ciclo de auditoria.

\subsubsection{Vantagens da Auditoria Integrada}

As vantagens da auditoria integrada podem ser resumidas como segue:

- Minimiza a duplicação de esforços e torna o acompanhamento mais efetivo. O processo como um todo é mais eficiente e disciplinado para o gerente da planta e auditores.

- As auditorias passam a ter um formato comum e possibilita o controle centralizado. Quando há necessidade de modificações é imediatamente efetivada e executada nas auditorias subseqüentes.

- As auditorias são focadas em requisitos mínimos autorizados pela diretoria.

- Há sinergismo entre as várias unidades que ajudam na solução de distinguir prioridades para as funções de segurança, saúde e meio ambiente.

- Pontos fortes e fracos das unidades de operação são imediatamente identificados.

- O questionário é o estado da arte da expectativa da empresa.

\subsubsection{Diretrizes para Auditoria de Sistemas de Gestão da Qualidade e Meio Ambiente}

A International Organization for Standardization - ISO, através de seu comitê técnico 176 (Gerenciamento da Qualidade) / Subcomitê 3 (Auditoria da Qualidade) e 
Subcomitê 207 (Gerenciamento Ambiental) / Subcomitê 2 (Auditoria Ambiental) editou na forma de Draft International Standard - DIS a ISO/DIS 19011 Geneva, 2002 - "Guidelines on Quality and/or Environmental Management Systems Auditing".

A ISO/DIS 19011 apresenta a Gestão de um Programa de Auditoria esquematizada na Figura 18 e conceito de competência dos auditores em qualidade e meio ambiente na Figura 19.

\subsubsection{A Integração do Gerenciamento de Risco com a Segurança, Saúde} e Meio Ambiente

Em 23 de Outubro de 1989, a Planta de Polietileno da Phillips em Pasadena, Texas, incendiou e explodiu ocasionando a morte de 23 pessoas. (Friedman, p. 65).

Segundo a Diretiva de Seveso de 1982 da Comunidade Européia, esses tipos de acidentes são definidos como "acidentes maiores" e provêm de uma ocorrência, tal como uma emissão, incêndio ou explosão envolvendo uma ou mais substâncias químicas perigosas, resultando de um desenvolvimento incontrolável no curso da atividade industrial, conduzindo a sérios perigos para o homem e o meio ambiente, imediatos ou a longo prazo, internamente ou externamente ao estabelecimento. (Freitas, Porto e Machado 2000, p. 26).

A análise crítica do acidente ocorrido no Complexo Industrial da Phillips, como parte do programa de prevenção de acidentes químicos, foi conduzida pela US.EPA e outras agências, através de uma auditoria, cujo propósito foram avaliar os procedimentos de prevenção e preparação a emergências; determinar o potencial e as conseqüências dos impactos da planta industrial.

Informações detalhadas foram coletadas, inclusive a descrição das características físicas do complexo, planejamento e atendimento a emergências; alerta público; procedimentos de comunicação, atividades de prevenção de segurança e perdas e a realização de investigação de acidentes.

A Occupational Safety and Health Administration - OSHA afirmou: "A Phillips, planta de polietileno, não tem utilizado o processo de análise de risco ou outro 
método equivalente para identificar riscos no processo ou potencial de riscos por mal funcionamento, erros humanos ou reduzir ou eliminar tais riscos".

Em 24 de Fevereiro de 1992 a OHSA publicou a regulamentação sobre o gerenciamento de risco.

As empresas devem:

1. Coletar informações sobre a segurança do processo e dados dos níveis de toxidade.

2. Manter procedimentos de segurança e comunicar aos funcionários os perigos de suas tarefas.

3. Treinar os trabalhadores para que eles entendam a natureza e as causas dos problemas que podem ocorrer e aumentar a conscientização sobre os perigos específicos.

4. Assegurar que os contratados que trabalham na planta tenham segurança e sejam treinados e informados adequadamente.

5. Inspeção periódica de desempenho dos equipamentos.

6. Emitir "Autorização para Trabalhos a Quente".

7. Estabelecer e manter procedimentos escritos antes da implementação de mudanças tecnológicas ou de equipamentos.

8. Uso de equipe especializada para a investigação de incidentes significativos.

9. Desenvolvimento de planos de emergência.

10. Conduzir auditorias de segurança no mínimo a cada três anos para assegurar a efetividade do programa de gerenciamento de risco (Friedman 1995, p. 66).

\subsubsection{Elementos da Integração de Sistemas}

A correspondência entre os elementos da OHSAS 18001:1999 e a ISO 14001:1996 é apresentada no Quadro 5.

O objetivo da comparação é demonstrar a compatibilidade de ambos os sistemas para aquelas organizações que já estão aplicando uma destas normas e que desejem aplicar ambas. 


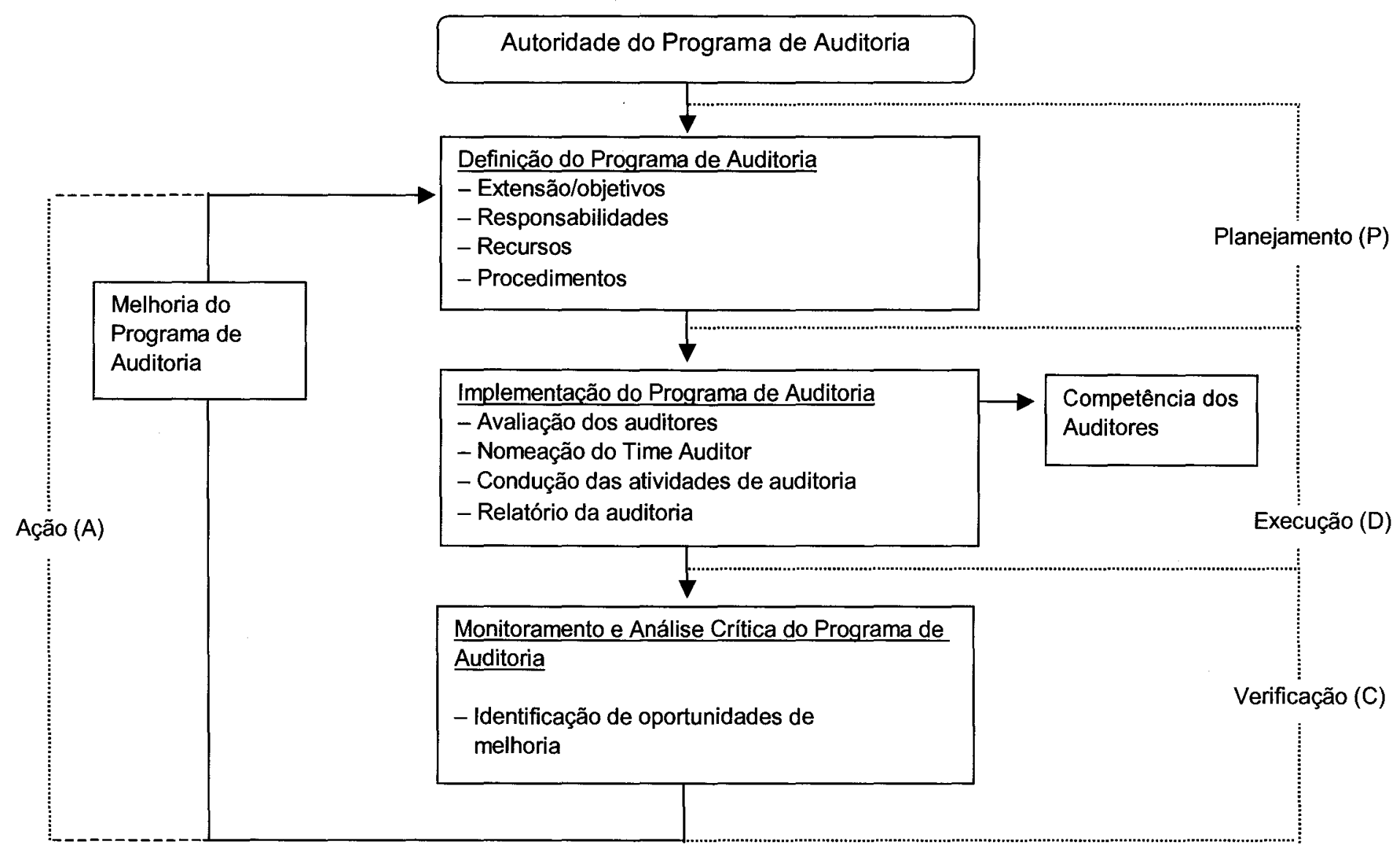

\section{Figura 18 - Ilustração do Ciclo PDCA para a Gestão de um Programa de Auditoria}

Fonte: ISO/DIS 19011 (Geneva, 2002) 


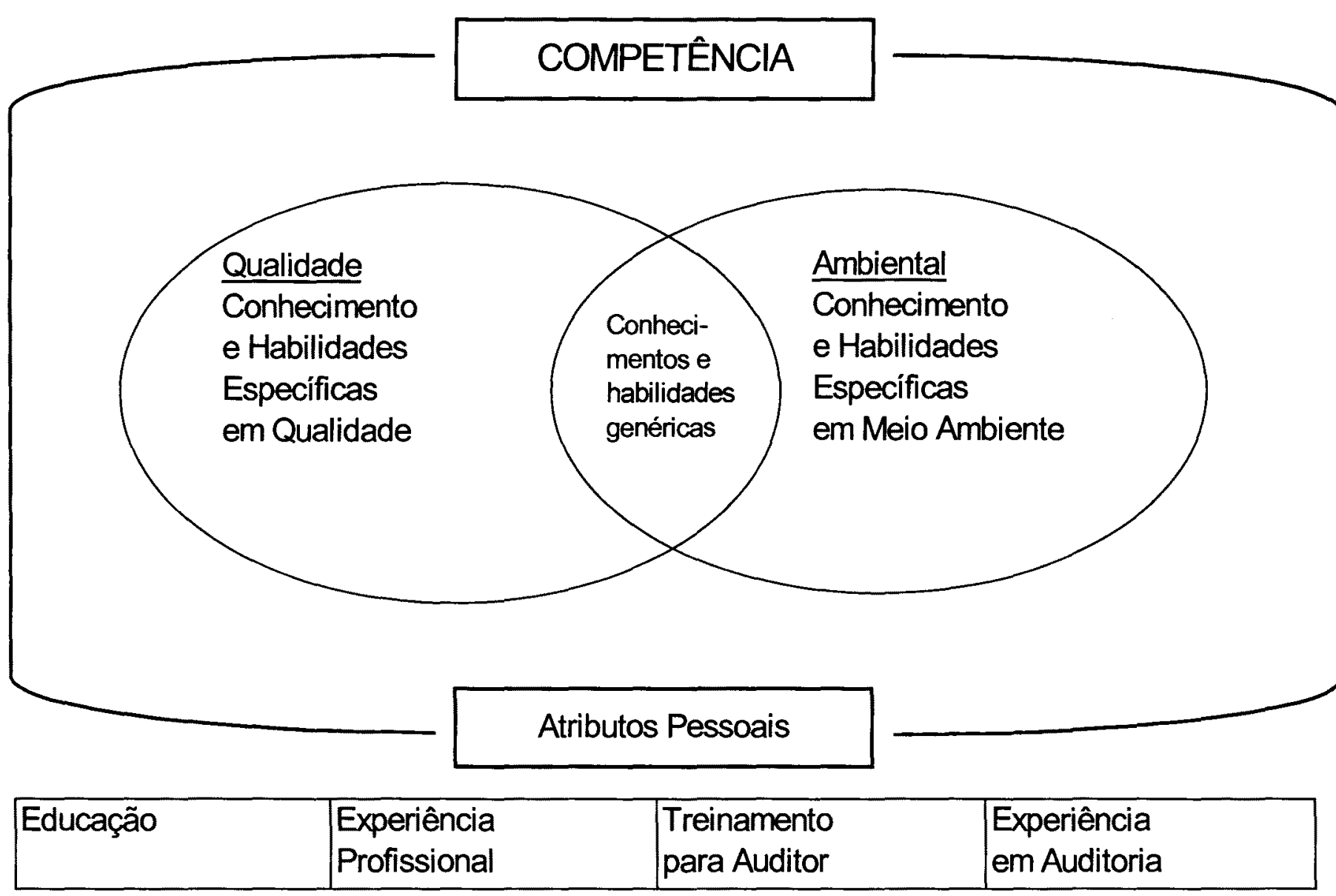

Figura 19 - Conceito de Competência

Fonte: ISO/DIS 19011 (Geneva, 2002) 
Quadro 5 - Comparação entre OHSAS 18001 e ISO 14001

\begin{tabular}{|c|c|c|c|}
\hline Cláusula & OHSAS 18001 & Cláusula & ISO 14001 \\
\hline 1 & Escopo & 1 & $\begin{array}{l}\text { Objetivo e campo de } \\
\text { aplicação }\end{array}$ \\
\hline 2 & Publicações de referência & 2 & Referências normativas \\
\hline 3 & Termos e definições & 3 & Definições \\
\hline 4 & $\begin{array}{l}\text { Elementos do sistema de } \\
\text { gestão OH\&S }\end{array}$ & 4 & $\begin{array}{l}\text { Requisitos do sistema de } \\
\text { gestão ambiental }\end{array}$ \\
\hline 4.1 & Requisitos gerais & 4.1 & Requisitos gerais \\
\hline 4.2 & Política OH\&S & 4.2 & Política ambiental \\
\hline 4.3 & Planejamento & 4.3 & Planejamento \\
\hline 4.3.1 & $\begin{array}{l}\text { Planejamento para } \\
\text { identificação de perigos, } \\
\text { avaliação e controle de } \\
\text { riscos }\end{array}$ & 4.3.1 & Aspectos ambientais \\
\hline 4.3 .2 & $\begin{array}{l}\text { Requisitos legais e outros } \\
\text { requisitos }\end{array}$ & 4.3.2 & $\begin{array}{l}\text { Requisitos legais e outros } \\
\text { requisitos }\end{array}$ \\
\hline 4.3.3 & Objetivos & 4.3.3 & Objetivos e Metas \\
\hline 4.3 .4 & $\begin{array}{l}\text { Programa (s) de gestão } \\
\text { OH\&S }\end{array}$ & 4.3.4 & $\begin{array}{l}\text { Programa (s) de gestão } \\
\text { ambiental }\end{array}$ \\
\hline 4.4 & Implementação e operação & 4.4 & Implementação e operação \\
\hline 4.4.1 & $\begin{array}{l}\text { Estrutura e } \\
\text { Responsabilidade }\end{array}$ & 4.4.1 & $\begin{array}{l}\text { Estrutura e } \\
\text { Responsabilidade }\end{array}$ \\
\hline 4.4 .2 & $\begin{array}{l}\text { Treinamento, } \\
\text { conscientização e } \\
\text { competência }\end{array}$ & 4.4 .2 & $\begin{array}{l}\text { Treinamento, } \\
\text { conscientização e } \\
\text { competência }\end{array}$ \\
\hline 4.4 .3 & Consulta e comunicação & 4.4.3 & Comunicação \\
\hline 4.4.4 & Documentação & 4.4.4 & Documentação do SGA \\
\hline 4.4.5 & $\begin{array}{l}\text { Controle de documentos e } \\
\text { dados }\end{array}$ & 4.4.5 & Controle de documentos \\
\hline 4.4.6 & Controle operacional & 4.4.6 & Controle operacional \\
\hline
\end{tabular}


Quadro 5 - Comparação entre OHSAS 18001 e ISO 14001 - cont.

\begin{tabular}{|c|c|c|c|}
\hline Cláusula & OHSAS 18001 & Cláusula & ISO 14001 \\
\hline 4.4.7 & $\begin{array}{l}\text { Preparação e atendimento } \\
\text { a emergência }\end{array}$ & 4.4.7 & $\begin{array}{l}\text { Preparação e atendimento } \\
\text { a emergência }\end{array}$ \\
\hline 4.5 & Verificação e ação corretiva & 4.5 & Verificação e ação corretiva \\
\hline 4.5.1 & $\begin{array}{l}\text { Desempenho, medição e } \\
\text { monitoramento }\end{array}$ & 4.5.1 & Monitoramento e medição \\
\hline 4.5 .2 & $\begin{array}{l}\text { Acidentes, incidentes, não } \\
\text { conformidade, ação } \\
\text { corretiva e ação preventiva }\end{array}$ & 4.5 .2 & $\begin{array}{l}\text { Não conformidade e ações } \\
\text { corretiva e preventiva }\end{array}$ \\
\hline 4.5.3 & $\begin{array}{l}\text { Registros e gestão de } \\
\text { registros }\end{array}$ & 4.5.3 & Registros \\
\hline 4.5.4 & Auditoria & 4.5.4 & Auditoria do SGA \\
\hline 4.6 & $\begin{array}{l}\text { Análise crítica pela } \\
\text { administração }\end{array}$ & 4.6 & $\begin{array}{l}\text { Análise crítica pela } \\
\text { administração }\end{array}$ \\
\hline Anexo A & $\begin{array}{l}\text { Correspondência com ISO } \\
14001 \text {, ISO } 9001\end{array}$ & Anexo B & $\begin{array}{l}\text { Correspondência entre ISO } \\
14001 \text { e ISO } 9001\end{array}$ \\
\hline- & Bibliografia & Anexo C & Bibliografia \\
\hline- & Vide OHSAS 18002 & Anexo A & $\begin{array}{l}\text { Diretrizes para uso da } \\
\text { especificação }\end{array}$ \\
\hline
\end{tabular}

Fonte: BSI-OHSAS 18001 (1999, p. 12).

\subsection{Gerenciamento de Riscos}

A palavra "risco" deriva do italiano antigo riscare que significa "ousar". Neste sentido, o risco é uma opção e não um destino. É das ações que ousamos tomar das quais dependem de nosso grau de liberdade de opção (Bernstein, p. 8).

O Quadro 6 estabelece a questão dos riscos industriais e de seus impactos sobre a saúde e o meio ambiente através da retrospectiva histórica, atualidade e visạo futura 
acerca da formação dos atuais padrões de trabalho, produção e consumo nas sociedades ocidentais contemporâneas.

\section{Quadro 6 - Riscos Industriais}

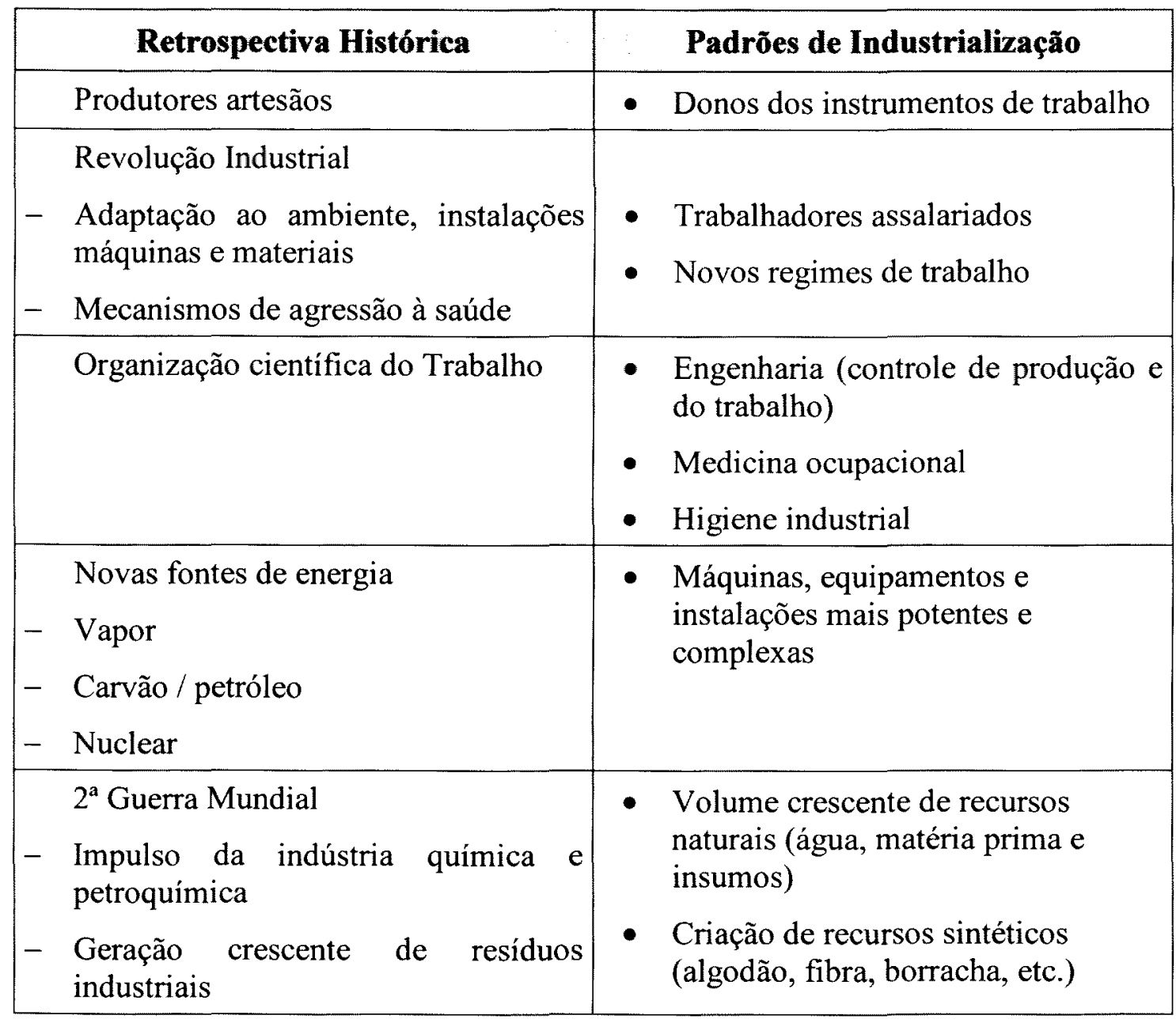

Fonte: Franco Druck (1998, pp. 61-72) 
Quadro 6 - Riscos Industriais - cont.

\begin{tabular}{|c|c|}
\hline Atualidade & Padrões de Industrialização \\
\hline $\begin{array}{ll} & \text { Globalização da economia } \\
\text { - } & \text { Problemas ambientais locais e globais } \\
\text { - } & \text { Investimentos redirecionados } \\
\text { (disponibilidade de recursos naturais } \\
\text { e custo de mão de obra) } \\
\text { - } & \text { Atividades de países e sociedade } \\
\text { permissiva em termos de direitos } \\
\text { trabalhistas e ambientais } \\
\text { - } & \text { Lógica financeira com graves } \\
\text { conseqüências no plano do emprego e } \\
\text { da produção } \\
\text { - Volatilidade dos capitais fictícios e } \\
\text { improdutivos }\end{array}$ & $\begin{array}{l}\text { - Mecanização do processo de } \\
\text { trabalho } \\
\text { - Integração da produção, controle e } \\
\text { concepção de produtos e serviços } \\
\text { - Inovações tecnológicas de } \\
\text { informática e das telecomunicações }\end{array}$ \\
\hline
\end{tabular}

\begin{tabular}{|c|c|}
\hline Visão Futura & Padrôes de Industrialização \\
\hline Reestruturação Produtiva & $\begin{array}{l}\text { - Desenvolvimento sustentável } \\
\text { - Crescimento econômico e emprego } \\
\text { - Equidade social }\end{array}$ \\
\hline Atores Sociais & $\begin{array}{l}\text { - Padrões inovadores de gestão, } \\
\text { organização do trabalho e da } \\
\text { produção } \\
\text { - Responsabilidade social } \\
\text { - Visibilidade }\end{array}$ \\
\hline
\end{tabular}

Fonte: Adaptação do artigo Padrões de Industrialização, Riscos e Meio Ambiente Franco e Druck (1998, pp. 61-72).

O estudo de risco pode ser definido como um processo de estimativa da probabilidade de ocorrência de um evento e a magnitude provável de seus efeitos adversos (econômicos, sobre a saúde e segurança humana, ou ainda ecológico) durante um período de tempo especificado (Galvão 2001). 
Peter Drucker afirma não conhecer empreendedor bem sucedido que tenha propensão a correr riscos. O que esses empresários fazem, é tentar definir quais precisam ser enfrentados e minimizá-los ao máximo. Embora o conceito de gerenciamento de riscos, que é o processo de selecionar e implementar medidas para alterar os níveis de risco, pareça lógico, ainda são poucas as empresas que o utilizam de maneira sistemática e de forma abrangente.

A aplicação do gerenciamento de riscos na prática pode variar muito de uma empresa para outra. O trabalho começa com a identificação dos riscos e sua classificação de acordo com dois parâmetros: probabilidade e impacto. $O$ passo seguinte é a definição de prioridades.

Para qualquer empresa, o principal benefício do gerenciamento de riscos é permitir vislumbrar com antecedência os perigos que podem ameaçar o negócio. Eles podem estar escondidos na perda constante de pessoas chaves, na exposição demasiada a um só mercado, no descuido com a imagem ou até mesmo fora dos muros da organização (Ferraz 2002).

\subsubsection{Identificação e Avaliação de Risco}

Segundo Nardocci (1999), a avaliação de riscos pode ser entendida como o conjunto de metodologias que calculam e avaliam a probabilidade de um efeito adverso ser provocado por um agente (químico, físico ou biológico), ou por um processo industrial, ou por uma tecnologia ou processo natural, que possa prejudicar a saúde humana e/ou ambiente. O gerenciamento dos riscos é o conjunto de procedimentos, normas e regras, tendo como objetivo controlar e minimizar riscos.

Galvão Filho (2001) comenta que o estudo e a análise de risco (risk assessment and risk analysis) são usados como sinônimos, porém define estudo de risco como um processo de estimativa da probabilidade de ocorrência de um evento e a magnitude provável de seus efeitos adversos (econômicos, sobre a saúde e segurança humana, ou ainda ecológico), durante um período de tempo especificado. A Norma BS 8800/96 define risco como a combinação da probabilidade de acontecimento e das conseqüências de um evento perigoso específico (acidente ou incidente). 
Porém o uso do conceito de risco possui um grande número de adjetivos, significando coisas diferentes para pessoas diferentes, por exemplo, o risco financeiro de se aplicar na bolsa de valores, o risco das empresas de seguro, as fatalidades de um acidente de uma planta de energia nuclear, etc., comprometendo a exata compreensão do conceito e a definição das ações de gerenciamento.

Nardocci (1999) afirma que os riscos podem ser divididos em objetivos e subjetivos, dos quais os primeiros são estimados com base em cálculos estatísticos, enquanto os subjetivos são avaliados com base em julgamentos intuitivos. Entre os riscos objetivos encontramos algumas designações:

- Riscos para a saúde humana

- Riscos ambientais

- Tecnológicos

- Epidemiológicos

- Industriais

- Acidentais

- Ecológicos

- Nucleares, etc.

Já os riscos subjetivos referem-se à fonte geradora do risco ou ao sujeito exposto a ele. Assim para a caracterização de um risco, é necessária a existência simultânea de dois elementos: uma fonte (perigo) e um sujeito. A fonte pode variar desde um objeto, uma ação, atividade ou até mesmo o estilo de vida das pessoas. Os sujeitos de interesse são o ser humano e/ou qualquer outro elemento de um ecossistema. A existência isolada de apenas um desses fatores não torna possivel caracterizar um risco. Já a Norma BS 8800/96 informa que para haver um risco deve sempre possuir dois elementos: a probabilidade de que um perigo possa ocorrer e as conseqüências desse perigo.

Nardocci (1999) comenta que os riscos para a saúde humana podem ser classificados em três grupos, considerando as metodologias de avaliação quantitativa de riscos existentes: 
- Riscos tecnológicos: decorrentes de eventos acidentais não naturais e caracterizados essencialmente por efeitos imediatos (mortes ou efeitos irreversíveis à saúde humana).

- Riscos ambientais: causados por fatores ou mudanças ambientais induzidas por atividades antropogênicas e associados a efeitos crônicos.

- Riscos naturais: causados por fenômenos naturais como enchentes, terremotos, vulcões, etc., podendo estar associado a efeitos imediatos ou de longo prazo.

A avaliação dos riscos tecnológicos analisa essencialmente a segurança industrial, com técnicas que visam identificar possíveis cenários acidentais, avaliando seus efeitos físicos e estimando a freqüência de ocorrência desses eventos. O material de estudo compreende todas as informações técnicas e operacionais dos sistemas existentes na planta em estudo.

Todos os estudos começam com a identificação dos perigos (hazard) ou definição do problema, em que o perigo pode significar coisas diferentes, dependendo do contexto. O perigo é um agente químico, biológico ou físico ou um conjunto de condições que se apresenta como uma fonte de risco, mas não o risco propriamente dito.

Após os perigos serem identificados, o próximo passo é identificar a população de receptores potenciais e os locais de exposição. A avaliação da exposição tem por objetivo a determinação da dose recebida pelos indivíduos expostos aos perigos identificados, ou seja, ocorrência em tempo e espaço do perigo e o receptor. Seguindo as recomendações da Norma BS 8800/96, após a identificação dos perigos há a fase da determinação dos riscos pela estimativa da gravidade potencial de perigo e da probabilidade de que este venha ocorrer. Com a análise dos resultados dessa fase, podemos decidir se os riscos são toleráveis, isto é, que os riscos foram reduzidos ao nível mais baixo, sendo razoavelmente aplicável.

Essa fase, em que é julgado se um determinado nível de risco é aceitável ou não, chamamos de gerenciamento de risco, na qual envolverá questões técnicas, sociais, políticas e éticas para as tomadas de decisões, em que podem ser adotados alguns 
métodos de auxílio, como o balanço risco/benefício ou custo/benefício e a análise comparativa de riscos.

Em 1969, um estudo de acidentes industriais realizado com 297 empresas, representando 21 segmentos industriais, com 1.750 .000 funcionários com mais de 3 bilhões de hora-homem de trabalho e 1.753 .498 acidentes registrados durante o período de estudo, revelou as seguintes taxas de acidentes: para cada acidente pessoal com lesão grave, correspondem 10 acidentes com lesão leve, 30 impessoais (sem vítima) e 600 ocorrências sem lesão e sem danos materiais.

O estudo da taxa de acidente ficou conhecido no mercado como Pirâmide de Frank Bird e representado conforme Figura 20.

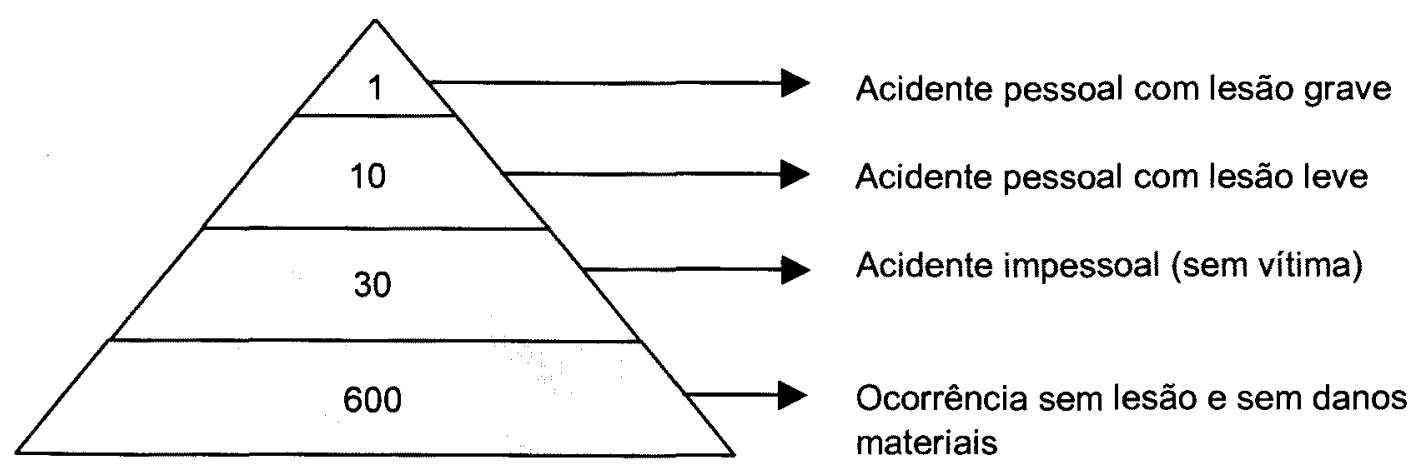

Figura 20 - Pirâmide de Frank Bird

Fonte: Bird e Loftus (1976, p. 34)

Uma boa prática de gestão é treinar e conscientizar os funcionários da empresa para que os problemas identificados que podem causar acidentes no local de trabalho, sejam registrados e comunicados a uma comissão que investiga e analisa os acidentes. A situação irregular, fora de padrão, deve ser divulgada, sinalizada, isolada e eliminada.

\subsection{Eficiência Operacional da Indústria}

Muitas organizações estão buscando caminhos para entender, demonstrar e melhorar a sua eficiência operacional. A avaliação do ciclo de vida é uma técnica para avaliação de aspectos ambientais associados a impactos potenciais com 
produtos e serviços e cujas diretrizes estão estabelecidas na ISO 14040, 14041, 14042 e 14043.

\subsubsection{A Avaliação do Ciclo de Vida - ACV}

As informações coletadas na Avaliação do Ciclo de Vida - ACV e os resultados de suas análises e interpretações podem ser úteis para tomadas de decisão, na seleção de indicadores ambientais relevantes para avaliação da performance de projetos ou re-projetos de produtos ou processos e/ou planejamento estratégico.

A ACV encoraja as industrias a sistematicamente considerar as questões ambientais associadas aos sistemas de produção (insumos, matérias-primas, manufaturas, distribuição, uso, disposição, reuso, reciclagem).

Ajuda a melhorar o entendimento dos aspectos ambientais ligados aos processos produtivos de uma forma mais ampla.

A ACV serve de subsídio às estratégias de marketing (tipo de declarações ambientais ou esquemas de rotulagens).

A ACV ajuda ainda:

- A identificar oportunidades de melhoria dos aspectos ambientais considerando as várias fases de um sistema de produção.

- Na tomada de decisão.

- Na avaliação da performance ambiental.

- Na avaliação e seleção de componentes feitos de diferentes materiais.

O enfoque gerencial da análise do ciclo de vida de produtos constitui-se em uma forte tentativa de integração da qualidade tecnológica do produto, da qualidade ambiental e do valor agregado para o consumidor e para a sociedade. 
A ISO 14040 estabelece que a análise do ciclo de vida de produtos deve incluir a definição do objetivo e do escopo do trabalho, uma análise do inventário, uma avaliação de impacto e a interpretação dos resultados, como mostrado na Figura 21.

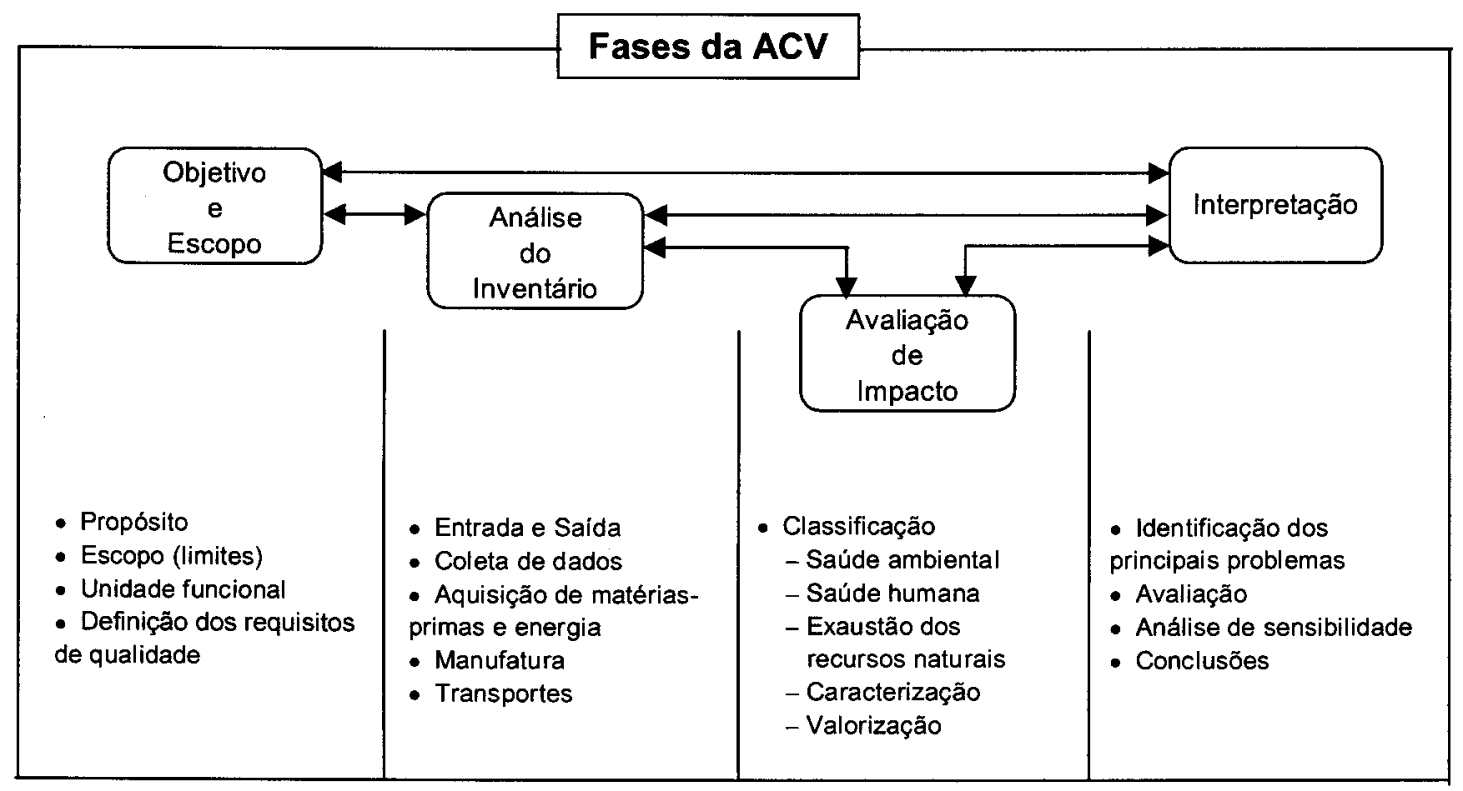

\section{Figura 21 - Fases da ACV}

Fonte: Chehebe (2002, p. 21)

\subsubsection{Definição de Objetivo e do Escopo da ACV}

Nessa fase, é definida a razão principal para a condução do estudo, sua abrangência e limites, a unidade funcional, a metodologia e selecionados os procedimentos considerados necessários para a garantia da qualidade do estudo.

A Norma ISO 14040 preconiza que na fase de definição dos objetivos seja esclarecida de forma clara e inequívoca a utilização que se pretende dar aos resultados do estudo, a que tipo de audiência se destina e o processo de revisão crítica que se pretende adotar. Essas definições, que estabelecem a funcionalidade do sistema (não importa se produtos ou serviços), devem ser dadas antes da formulação da metodologia a ser utilizada e, como influência o resultado final, representam uma etapa chave de qualquer projeto de $\mathrm{ACV}$. 
É importante ressaltar o caráter preliminar de tais definições, pois a ACV é uma ferramenta interativa e faz parte de sua metodologia, a revisão, quando necessária, do planejamento inicial.

De uma forma simplificada a Norma ISO 14040 estabelece que o conteúdo mínimo do escopo de um estudo de $\mathrm{ACV}$ deve referir-se às suas três dimensões: a) onde iniciar e parar o estudo do ciclo de vida (a extensão da ACV); b) quantos e quais subsistemas incluir (a largura da $\mathrm{ACV}$ ); e c) o nível de detalhes do estudo (a profundidade da $\mathrm{ACV}$ ).

Estabelece, ainda, que tais dimensões devem ser definidas de forma compatível e suficiente para atender o estabelecido nos objetivos de estudo. A Figura 22 mostra, através de um gráfico, essas dimensões.

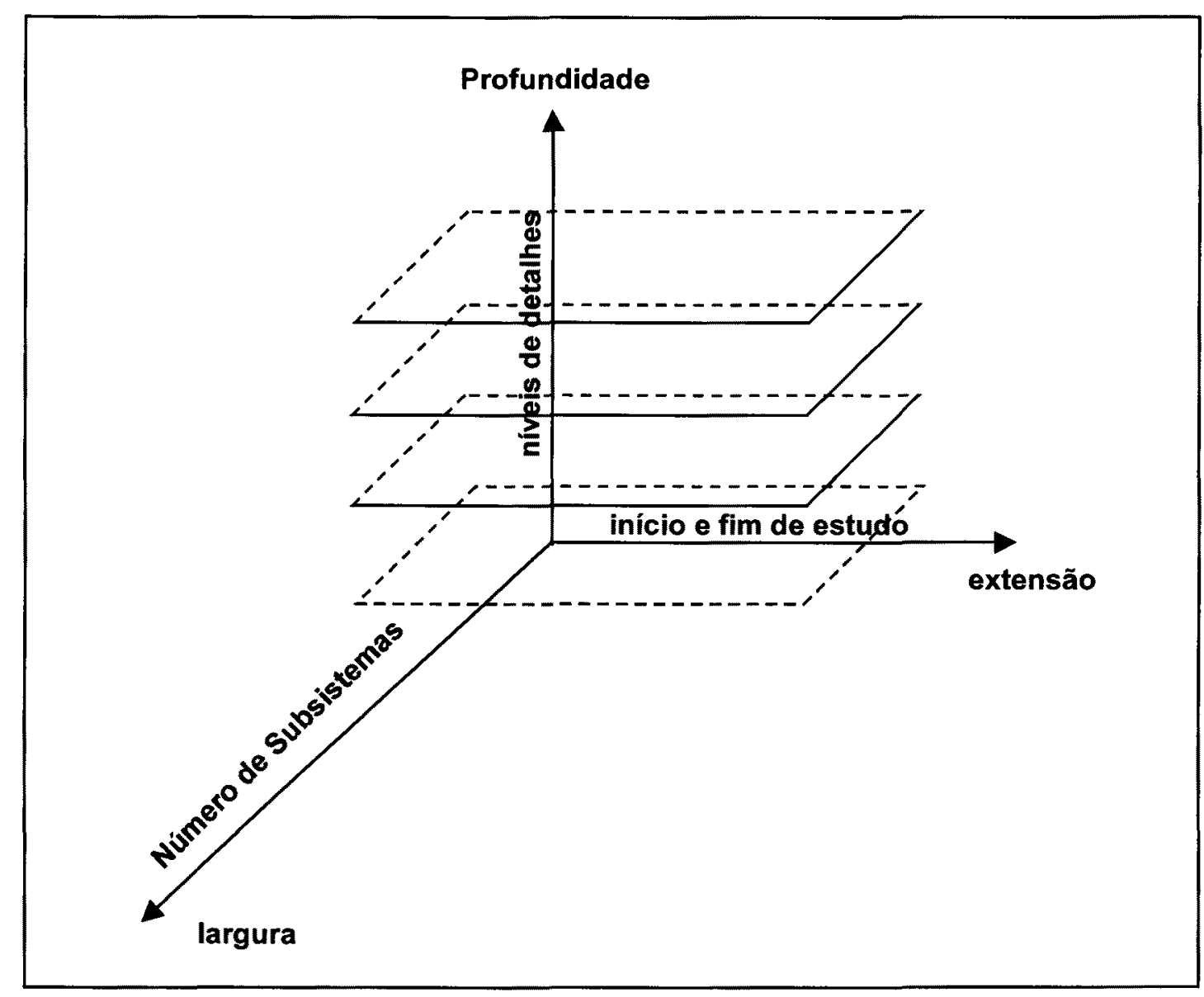

Figura 22 - Dimensões da ACV

Fonte: Chehebe (2002, p. 23) 


\subsubsection{Análise do Inventário do Ciclo de Vida}

A análise do inventário é a fase de coleta e quantificação de todas as variáveis (matéria-prima, energia, transporte, emissões para o ar, efluentes, resíduos sólidos, etc.) envolvidas durante o ciclo de vida de um produto (análise horizontal), processo ou atividade (análise vertical). A condução do inventário é um processo interativo. A seqüência de eventos invariavelmente envolve a checagem de procedimentos de forma a assegurar de que os requisitos de qualidade estabelecidos na primeira fase sejam obedecidos.

A Norma ISO 14040 estabelece os parâmetros gerais para a análise de inventários e a Norma ISO 14041 estabelece seus procedimentos de forma mais detalhada.

A Norma ISO 14040 estabelece um esquema geral para o inventário e deve ser constituído:

- da apresentação do sistema de produto a ser estudado e dos limites considerados em termos dos estágios de ciclo de vida, unidades de processos e entradas e saídas do sistema;

- da base para comparação entre sistemas (em estudos comparativos);

- dos procedimentos de cálculo e da coleta de dados, incluindo-se as regras para a alocação de produtos e o tratamento dispensado à energia.

- dos elementos necessários a uma correta interpretação, por parte do leitor, dos resultados da análise do inventário.

\subsubsection{Avaliação do Impacto}

Representa um processo qualitativo / quantitativo de entendimento e avaliação da magnitude e significância dos impactos ambientais baseados nos resultados obtidos na análise do inventário. O nível de detalhe, escolha dos impactos a ser avaliados e a metodologia utilizada dependem do objetivo e do escopo do estudo. 


\subsubsection{Interpretação}

Consiste na identificação e análise dos resultados obtidos nas fases de inventário e/ou avaliação de impactos de acordo com o objetivo e o escopo previamente definidos para o estudo. Os resultados dessa fase podem tomar a forma de conclusões e recomendações aos tomadores de decisão (Chehebe 2002).

\subsubsection{A Avaliação do Desempenho de Processos Industriais}

A avaliação do desempenho de processos industriais usa indicadores comparativos entre resultados passados e presentes da organização e segue o modelo de gestão da Figura 23, "Plan - Do - Check - Act" ou "Planejar - Realizar Verificar - Atuar". 


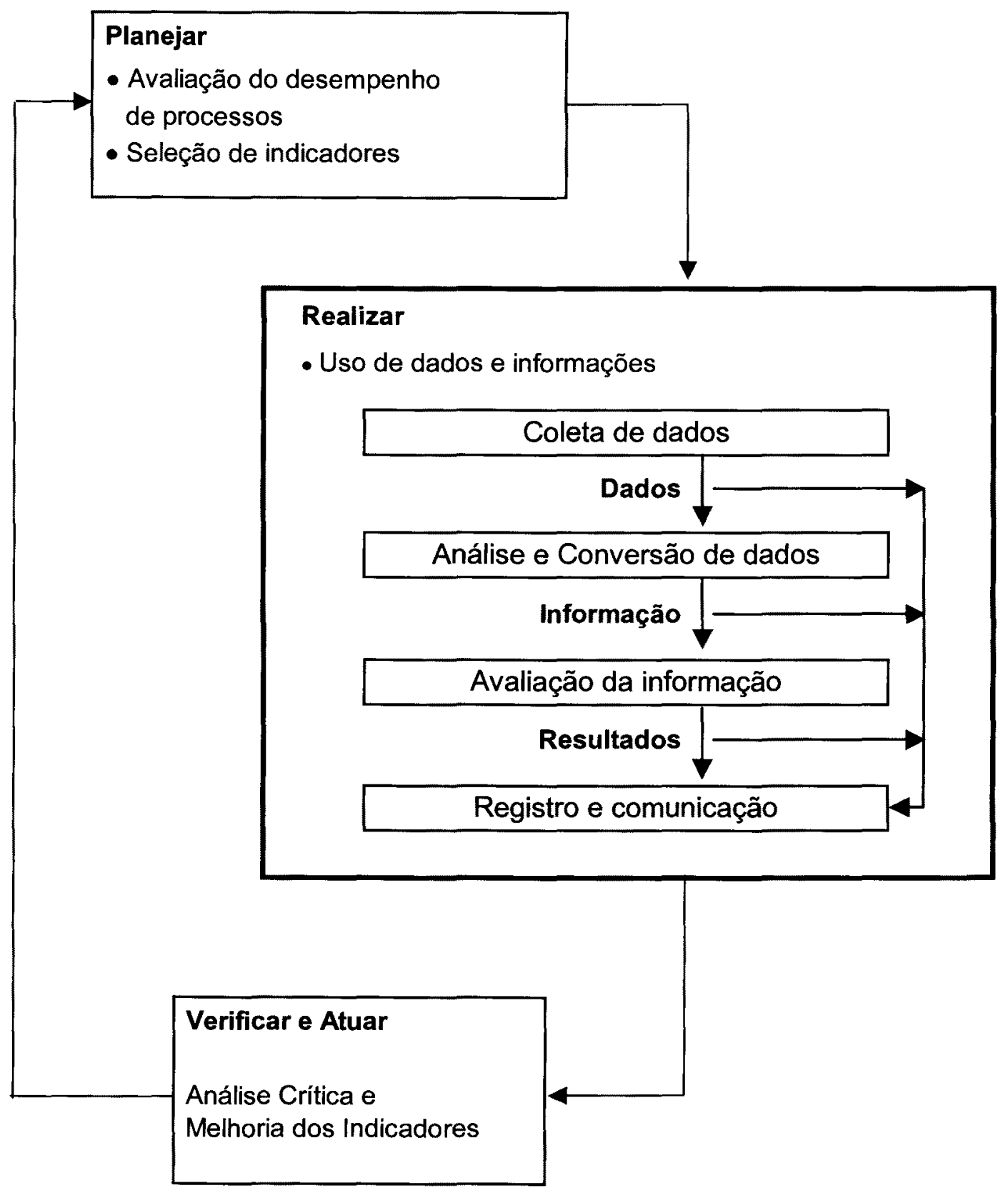

Figura 23 - Avaliação do Desempenho de Processos Industriais

Fonte: ISO $14031(1999$, p. 4)

A organização seleciona indicadores como dados quantitativos, qualitativos ou informações para melhor entendimento dos processos industriais. 
Informações que descrevem o desempenho de processos industriais podem ser desenvolvidas usando cálculo, estimativa, métodos estatísticos, técnicas gráficas, indices, porcentagens ou unidades de medida.

A análise de dados a partir de informações expressas em indicadores podem indicar melhoria ou deficiência. Os resultados podem ajudar a entender por que os critérios do desempenho de processos industriais são ou não atingidos.

O MCT 2003 define indicador de desempenho de processo como:

"É um parâmetro numérico que permitindo observar a situação dos elementos que afetam os resultados sempre estão vinculados aos meios e causas. Devem ser relevantes e estar alinhados aos fatores críticos para o sucesso da organização".

A seleção e construção de indicadores adequados é uma tarefa extremamente complexa e cada organização precisa definir suas próprias formas de mensurar seus resultados.

John Hartwell citado por Bernstein (1997, p. 251) afirmou que:

"Desempenho significa buscar resultados superiores à média em períodos de tempo razoavelmente longos - sistematicamente", ou ainda, indicadores são formas de representação quantificável de características de produtos e processos, utilizados para acompanhar e melhorar os resultados ao longo do tempo (Batista 2001, p. 20).

(...) "É preciso manter uma posição estratégica clara porque daí vem a vantagem competitiva. Quem sustentou um nível de lucro elevado, pode não ter recorrido às melhores práticas, mas foi claro quanto aos seus objetivos e metas estratégicos, ligados com a escolha dos fatores que diferenciam a empresa na busca da eficiência operacional, que é fazer a mesma coisa, só que melhor" (Porter 2003).

Portanto, conclui-se que uma organização voltada para resultados apresenta uma integração profunda de todos os sistemas organizacionais em torno de especificações de resultados relativos à organização no seu todo, especificações de resultados relativos às unidades que constituem a organização e especificações de resultados relativos a todos os gestores individuais. As principais características desse tipo de organização são as seguintes:

- Conta com uma especificação dos resultados a atingir. 
- Dispõe de uma estrutura organizacional permitindo atingir os resultados especificados.

- Existe uma clara compreensão, por parte de todos os setores, do significado dos conceitos de resultados, eficiência e eficácia.

- Há uma integração dos sistemas chaves com o conceito de resultados.

- Ocorre uma articulação entre os resultados da organização, das suas unidades e dos gestores individuais.

- É capaz de responder de maneira flexível para atingir os resultados;

- Cria um modo próprio de lidar com os resultados resistindo a copiar os dos outros.

Um elemento essencial na gestão com foco em resultados é o uso de indicadores no processo de tomada de decisões (Batista, p. 2).

A avaliação dos indicadores de desempenho é feita em diversos níveis conforme apresentado no modelo da Figura 24.

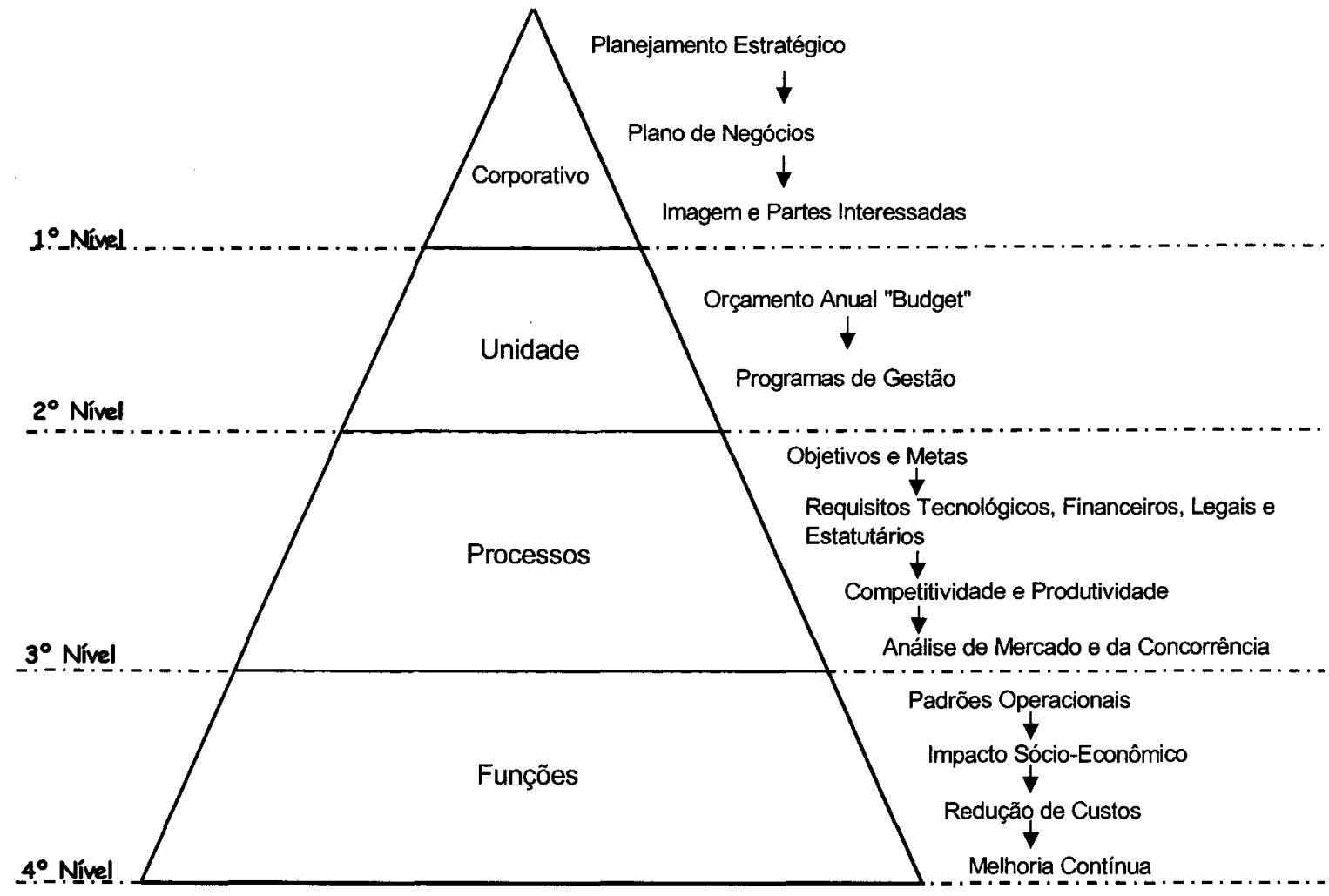

Figura 24 - Hierarquia dos Indicadores de Desempenho da Organização 


\subsubsection{Análise de Desempenho}

A introdução à teoria dos sistemas proposta por Churchman citada por Fonseca, em 1996, é descrita a seguir:

\section{Sistema}

A teoria dos sistemas, assim como a abordagem sistêmica, consolidou-se em meados do século XX.

Um sistema é um conjunto de partes (elementos) coordenadas (interrelacionados) para realizar um conjunto de finalidades. São cinco as considerações básicas quando se pensa sobre o significado de um sistema: objetivos, ambiente, recursos, componentes e administração.

\section{Objetivos do sistema}

Os objetivos do sistema, como um todo, representam o ponto de partida na definição do sistema. Os objetivos devem ser explicitados o máximo possível, de preferência, com o uso de medidas precisas e específicas de rendimento do sistema global.

\section{O ambiente do sistema}

O ambiente do sistema é tudo aquilo que está situado "fora" do sistema. Algo está "fora" quando o sistema pode fazer relativamente pouco a respeito das características ou do comportamento de tal coisa.

A concorrência dever ser vista como uma oportunidade para a melhoria do desempenho. É preciso identificar as melhores práticas em uso pelas empresas do ramo e tentar superá-las. Assim, o benchmarking deve ser tomado como premissa para a elaboração de indicadores de competitividade. 


\section{Os recursos do sistema}

Os recursos do sistema encontram-se dentro do sistema. Eles são os meios que o sistema usa para desempenhar suas tarefas. Ao contrário do ambiente, os recursos são administrados pelo sistema.

De modo geral, será considerado que os recursos da produção podem ser agrupados em hardware, software e humanware.

O hardware diz respeito aos bens utilizados, como: recursos naturais, matériaprima, equipamentos e instalações. O software consiste no acervo de informações explícitas relativas à maneira de fazer as coisas: procedimentos, tecnologia de informações e padrões operacionais. O humanware é o conjunto de pessoas que participam do processo produtivo.

\section{Os componentes do sistema}

Os componentes do sistema devem ser criados a partir da identificação das missões básicas que o sistema deve cumprir para o atendimento de seus objetivos. São estipulados a partir da decomposição racional de tarefas que o sistema deve executar. Portanto, as medidas de desempenho do sistema devem ser feitas de modo a captar o quanto cada subsistema está contribuindo para o atendimento da missão do sistema global.

Missão exprime a razão da existência da empresa. É com base na missão que a empresa deve definir seus objetivos principais, inclusive sua estratégia competitiva. Isso cabe à administração da empresa.

Com base no enfoque dos sistemas é possível fazer uma distinção entre eficiência e eficácia. Um sistema eficiente é aquele que utiliza racionalmente seus recursos. A eficácia é a capacidade do sistema cumprir a finalidade para qual foi concebido.

\section{A administração do sistema}

A administração do sistema é a tomada de decisões sobre os objetivos a serem alcançados e sobre a utilização de recursos. 


\subsubsection{Medição do Desempenho Operacional}

As técnicas e ferramentas de gestão para a avaliação das organizações desenvolvem-se rapidamente e o check list está sendo usado como padrão industrial para a medição do desempenho operacional e enquadramento das empresas em níveis de desempenho de classe mundial.

O check list é uma ferramenta de gestão empregada pela Oliver Wight Internacional. O método utiliza pontuação variando de 0 a 4 de acordo com o Quadro 7 e foi escolhido pelas seguintes razões:

$>$ Reconhece o trabalho das pessoas, apesar de a empresa ainda não atingir o nível de excelência.

$>$ Indica onde e quanto é necessário de esforço adicional para a obtenção do resultado classe $\mathrm{A}$.

$>$ Provê meio para a melhoria contínua.

\section{Quadro 7 - Níveis de Desempenho Operacional}

\begin{tabular}{|l|l|}
\hline \multicolumn{1}{|c|}{ Pontuação } & \multicolumn{1}{c|}{ Significado } \\
\hline $\begin{array}{l}\text { Excelente } \\
\text { pontos }\end{array}$ & $\begin{array}{l}\text { Quando o desempenho da atividade ultrapassar o nível } \\
\text { esperado. }\end{array}$ \\
\hline $\begin{array}{l}\text { Bom } \\
3 \text { pontos }\end{array}$ & $\begin{array}{l}\text { Quando o desempenho da atividade atende integralmente os } \\
\text { objetivos. }\end{array}$ \\
\hline $\begin{array}{l}\text { Regular } \\
2 \text { pontos }\end{array}$ & $\begin{array}{l}\text { Quando a maior parte dos processos e ferramentas está } \\
\text { adequada, porém os resultados não estão sendo atingidos. }\end{array}$ \\
\hline $\begin{array}{l}\text { Insatisfatório } \\
1 \text { ponto }\end{array}$ & $\begin{array}{l}\text { Pessoas, processos e ferramentas não atingem o nível } \\
\text { mínimo requerido com pequenos resultados e benefícios. }\end{array}$ \\
\hline $\begin{array}{l}\text { Não implementado } \\
0 \text { pontos }\end{array}$ & A atividade é requerida, porém não está sendo aplicada. \\
\hline
\end{tabular}

Fonte: Wight (2000, p. 5)

O Quadro 8 apresenta o número de elementos principais, chaves e detalhados que fazem parte da metodologia do check list $\mathrm{ABCD}$. 
Quadro 8 - Check List ABCD

\begin{tabular}{|c|c|c|c|}
\hline \multicolumn{4}{|c|}{ CHECK LIST ABCD PARA A EXCELÊNCIA OPERACIONAL } \\
\hline \multicolumn{4}{|c|}{ Elementos } \\
\hline \multicolumn{2}{|r|}{ Principais } & Chaves & Detalhados \\
\hline 1. & Planejamento Estratégico de Processos & 16 & 55 \\
\hline 2. & Pessoas e Equipes de Processos & 8 & 53 \\
\hline 3. & $\begin{array}{l}\text { Qualidade Total e Melhoria Contínua de } \\
\text { Processos }\end{array}$ & 19 & 135 \\
\hline 4. & $\begin{array}{l}\text { Novos Produtos e Desenvolvimento de } \\
\text { Processos }\end{array}$ & 11 & 60 \\
\hline 5 . & Planejamento e Controle de Processos & 24 & 204 \\
\hline \multicolumn{2}{|r|}{ TOTAL } & 78 & 507 \\
\hline
\end{tabular}

Fonte: Wight (2000, pp. 13-153)

As questões do check list $\mathrm{ABCD}$ para a excelência operacional são respondidas em primeiro lugar para os elementos detalhados. Essas informações são usadas como guia para as respostas das questões dos elementos chaves.

O cálculo da pontuação é feito através da média numérica dos elementos chaves presente em cada elemento principal e o resultado é apresentado de acordo com o Quadro 9.

Quadro 9 - Pontuação do Check List ABCD

\begin{tabular}{|c|c|}
\hline \multicolumn{2}{|c|}{ EXCELÊNCIA OPERACIONAL } \\
\hline Média numérica & Nível da empresa \\
\hline$\geq 3,5$ & Classe $\mathrm{A}$ \\
\hline$\geq 2,5 \mathrm{e}<3,49$ & Classe $\mathrm{B}$ \\
\hline$\geq 1,5 \mathrm{e}<2,49$ & Classe $\mathrm{C}$ \\
\hline$<1,5$ & Classe $\mathrm{D}$ \\
\hline
\end{tabular}

Fonte: Wight (2000, p. 6) 
Obs.: A empresa deve manter o desempenho mínimo por três meses consecutivos.

A melhoria de desempenho dos processos envolve seis passos a serem implementados pela organização:

1. Avaliação da situação atual (diagnóstico).

2. Determinar as lacunas da organização e priorizá-las com base nas vantagens competitivas.

3. Introduzir o check list $\mathrm{ABCD}$ de acordo com as necessidades da empresa.

4. Desenvolver planos de ação.

5. Medir o progresso.

6. Conduzir reunião mensal de análise crítica dos resultados. 


\section{PLANEJAMENTO E MÉtodos dA PESQUiSA}

A pesquisa com enfoque e aplicação no processo industrial de laminação de aço não plano, foi desenvolvida devido a importância do produto no mercado global e as preocupações crescentes com a saúde e segurança do trabalhador envolvido direta ou indiretamente na cadeia produtiva e com os aspectos e impactos ambientais associados à atividade industrial.

\subsection{O Processo Industrial de Laminação de Aço não Plano}

Em geral, dois cilindros de aço liga de alta resistência à quente e a abrasão com motores de acionamento de elevada potência são necessários para a deformação mecânica de aço não plano.

Esse processo de deformação mecânica é denominado laminação e tem como finalidade conferir geometria redonda, quadrada, sextavada, perfil U, L e outros aos diversos tipos de materiais empregados na indústria.

É impossível determinar quando a laminação foi inventada, porém acredita-se que foi na época da descoberta e uso dos metais e após a invenção da roda. O homem descobriu muito cedo um outro método de conformação denominado forjamento que consiste na deformação plástica do metal entre o estado líquido e sólido.

Durante a Idade do Ferro, o homem aprendeu a extrair o minério e transformá-lo em aço e com isso se deu o desenvolvimento dos equipamentos de laminação e forja.

$\mathrm{Na}$ Idade Média os equipamentos de laminação eram movidos pela força da água, porém com o progresso do século XIX e XX e com o advento de fontes de energia elétrica e a vapor foi possível laminar diferentes tipos de produtos.

Os avanços tecnológicos trouxeram melhorias nos projetos dos cilindros, sistemas de acionamento, materiais, controles, tolerâncias e formas geométricas dos produtos, eficiência do trabalho de deformação e no consumo de energia. 


\subsubsection{Equipamentos de Laminação da Idade Média}

Nos séculos XIV e XV, a produção de peças e chapas metálicas era predominantemente feita através do processo de forjamento.

Por volta de 1500 , surgiram na Itália equipamentos para a laminação de chapas planas de metais maleáveis. As chapas eram utilizadas para estampagem de moedas.

$\mathrm{O}$ inventor e artista Leonardo da Vinci, juntamente com Donato Bramante e Benvenuto Cellini, construíram um laminador utilizado largamente na Europa na fabricação de moedas em ouro, prata e cobre.

\subsubsection{Equipamentos de Laminação do Século XIX}

A nova era de fabricação do aço, iniciou em 1864 , com a invenção dos fornos Siemens-Martin.

John Hazledine, em 1798, obteve a patente na Inglaterra do equipamento de laminação contínua, mostrado abaixo na Figura 25.

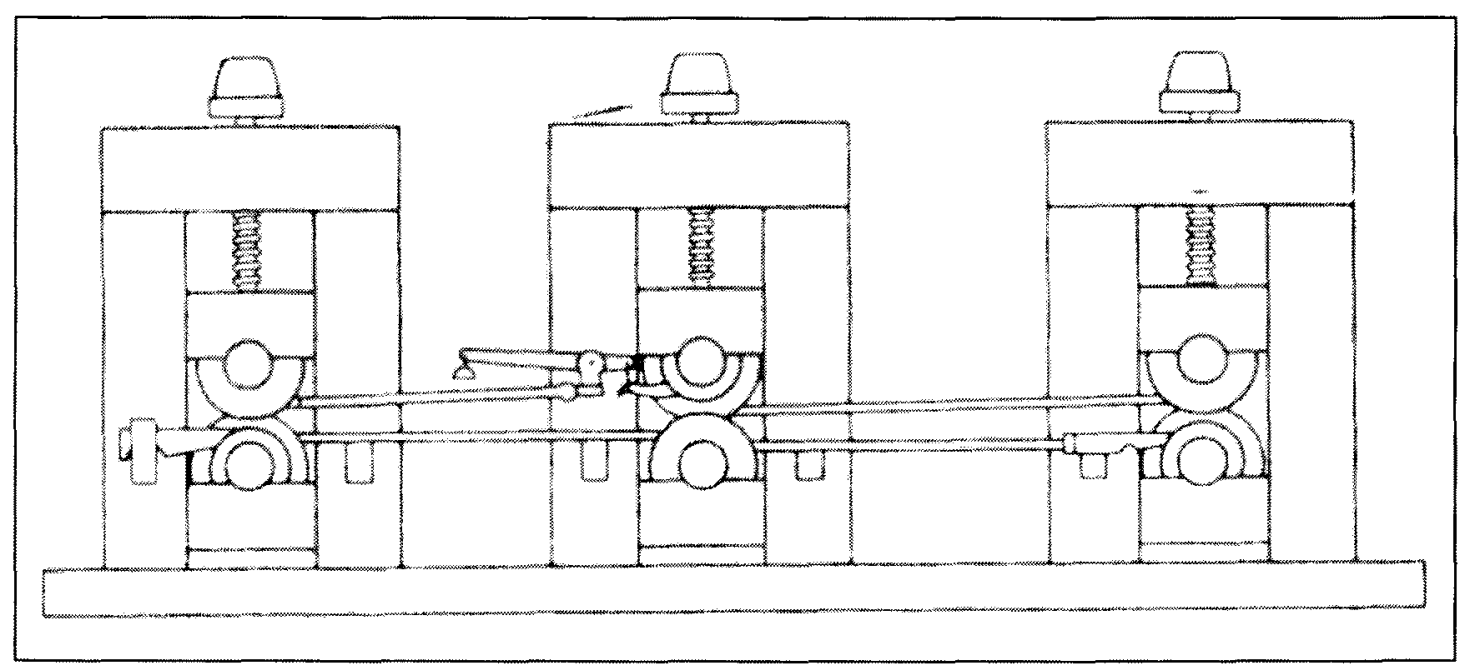

Figura 25 - Equipamento de Laminação Contínua 


\subsubsection{Equipamentos de Laminação do Século $X X$}

Os vários tipos de equipamentos de laminação foram classificados da seguinte maneira:

a) Pelas características de projeto, principalmente pelo arranjo dos cilindros de laminação duo, trio ou multi.

b) Pelo produto de laminação, tais como: tarugo, barras, chapas grossas, finas, tiras e etc.

c) Pelo uso do diâmetro dos cilindros de laminação ou largura da chapa laminada (ex. diâmetro 46" ou largura 160").

A classificação dos produtos de laminação está resumidamente apresentada no Diagrama de Fluxo da Figura 26.

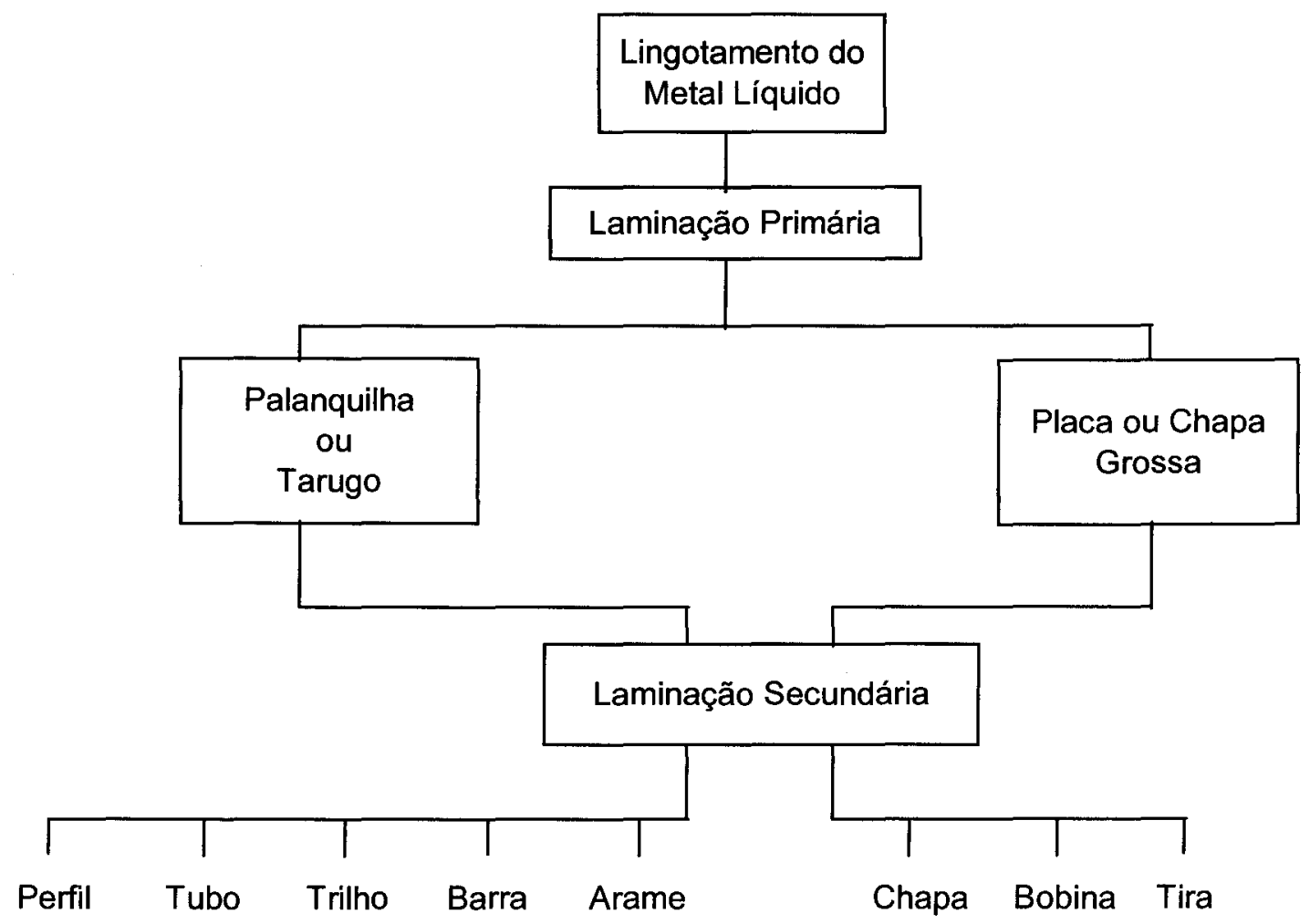

Figura 26 - Representação Esquemática do Fluxo de Material no Processo de

\section{Laminação}

Fonte: Adaptação; Corbertt (1990 p. 5). 


\subsubsection{Equipamentos de Laminação da Atualidade}

Os projetos atuais de equipamentos de laminação de aços não planos podem ser de cilindros trio não reversível para lingotes de pequenas dimensões e baixa produção ou duo reversível para lingotes de grandes dimensões e alta produção.

Usualmente os cilindros de laminação primária estão entre 700 a $1.150 \mathrm{~mm}$ de diâmetro. $\mathrm{O}$ peso dos lingotes entre 3 a 25 toneladas e as dimensões das palanquilhas e tarugos produzidos entre 150 a $400 \mathrm{~mm}$ com perfil redondo ou quadrado.

O processo de laminação secundária (produtos semi-acabados) está entre a laminação primária e a operação de acabamento (usinagem, estampagem, trefilação, conformação mecânica e outras) e tem como finalidade conferir forma geométrica e dimensional ao produto.

A principal função da laminação secundária é reduzir a seção da palanquilha ou tarugos para dimensões e perfis de uso comercial. Por exemplo: palanquilhas ou tarugos de 150 a $275 \mathrm{~mm}$ de seção quadrada são reduzidas na laminação secundária para 75 a $125 \mathrm{~mm}$ e assim por diante, porém antes de continuar a redução da seção é necessário executar uma operação de corte para facilitar o manuseio do produto final.

\subsubsection{A Planta Industrial Típica da Laminação de Aços Não Planos}

Atualmente a planta industrial de laminação está automatizada, tem-se o domínio das condições de riscos, perigos, aspectos e impactos sobre a saúde, meio ambiente e segurança do trabalho.

As equipes de SMS possuem especialização profissional e estão com enfoque e aplicação na prevenção de acidentes como ferramenta de gestão para a melhoria da eficiência operacional.

A identificação de equipamentos de proteção individual, tais como: óculos, luvas, capacete, aventais, perneiras, protetor auricular, entre outros, é relativamente fácil. Porém, a escolha de acessórios adequados para o risco de intoxicação ou envenenamento e o perigo de explosão já requerem estudo e mais conhecimento técnico. 
Ao lado dos acidentes propriamente ditos, há o problema das doenças ocupacionais, campo de alta especialização, em geral do domínio dos profissionais da área de saúde.

Dentro das usinas siderúrgicas costuma-se dizer que "a máquina puxa o homem", significando um tipo especial de tensão do trabalho, diferentemente do trabalho autônomo isolado. O trabalho é em equipe e a disputa faz parte do cotidiano.

A poluição sonora, a do ar, a do solo e água constituem centros de atenção e requerem muitas vezes vultuosos investimentos.

Todo esse conjunto de fatores, possivelmente alguns mais, requer uma consciência administrativa não mais se admitindo hoje que seja colocada em plano secundário.

Os principais aspectos e impactos de saúde e meio ambiente identificados nas atividades da laminação de aços não planos estão relacionados no Quadro 10.

Quadro 10 - Aspectos e Impactos de Saúde e Meio Ambiente nas Atividades da Laminação de Aços Não Planos

\begin{tabular}{|c|c|}
\hline Aspectos & Impactos \\
\hline $\begin{array}{l}\text { - ruído contínuo, intermitente ou de } \\
\text { impacto } \\
\text { - vibração }\end{array}$ & $\begin{array}{l}\text { - cansaço físico e mental } \\
\text { - } \text { irritabilidade } \\
\text { - diminuição temporária de audição } \\
\text { - } \\
\text { - } \\
\text { - dardez profissional }\end{array}$ \\
\hline $\begin{array}{l}\text { - radiações não ionizantes (infra- } \\
\text { vermelho e ultra-violeta) } \\
\text { - emissão de luminosidade }\end{array}$ & $\begin{array}{l}\text { - } \text { queimadura } \\
\text { - irritação } \\
\text { - danos à saúde do ser humano }\end{array}$ \\
\hline - calor & $\begin{array}{l}\text { - desconforto } \\
\text { - } \text { fadiga } \\
\text { - desidratação } \\
\text { - } \text { hipotensão } \\
\text { - choque térmico }\end{array}$ \\
\hline
\end{tabular}


Quadro 10 - Aspectos e Impactos de Saúde e Meio Ambiente nas Atividades da Laminação de Aços Não Planos - cont.

\begin{tabular}{|c|c|}
\hline Aspectos & Impactos \\
\hline $\begin{array}{l}\text { - instalação ou arranjo físico } \\
\text { inadequado (impacto de pessoas } \\
\text { contra objetos parados ou em } \\
\text { movimentos) }\end{array}$ & $\begin{array}{l}\text { - escoriações } \\
\text { - ferimentos corta-contusos } \\
\text { - ferimentos lacerantes } \\
\text { - } \text { contusão com hematoma } \\
\text { - entorse } \\
\text { - luxação } \\
\text { - traumatismo }\end{array}$ \\
\hline $\begin{array}{l}\text { - diferença de nível (escadas móveis e } \\
\text { fixas, torres, postes, estruturas, } \\
\text { telhados, andaimes, passagem em } \\
\text { plataformas, peças e equipamentos } \\
\text { de produção) }\end{array}$ & $\begin{array}{l}\text { - escoriações } \\
\text { - contusões com hematoma } \\
\text { - fraturas } \\
\text { - traumatismo }\end{array}$ \\
\hline $\begin{array}{l}\text { - } \begin{array}{l}\text { sistemas pressurizados } \\
\text { (ar comprimido e gases) }\end{array} \\
\end{array}$ & - lesões graves \\
\hline - esforço físico intenso & $\begin{array}{l}\text { - entorse } \\
\text { - luxações } \\
\text { - } \text { trauma de coluna, tendões } \\
\text { músculos } \\
\text { - hematomas }\end{array}$ \\
\hline - postura inadequada & - distensão de músculos e tendões \\
\hline - poeira & $\begin{array}{l}\text { - } \text { alteração da função pulmonar } \\
\text { - } \quad \text { alteração da qualidade do ar }\end{array}$ \\
\hline - chama ou superficie quente & - queimaduras de $1^{\circ}, 2^{\circ}$ e $3^{\circ}$ grau \\
\hline - consumo de energia elétrica & $\begin{array}{l}\text { - esgotamento de recursos naturais } \\
\text { energéticos }\end{array}$ \\
\hline - consumo de água & $\begin{array}{l}\text { - redução da disponibilidade de } \\
\text { recursos naturais }\end{array}$ \\
\hline $\begin{array}{l}\text { - consumo de gases (natural, GLP, } \\
\text { oxigênio, acetileno, nitrogênio e } \\
\text { etc.) }\end{array}$ & - esgotamento de recursos naturais \\
\hline - consumo de óleo, graxa e derivados & - esgotamento de recursos naturais \\
\hline - consumo de produtos químicos & $\begin{array}{l}\text { - danos à saúde do ser humano } \\
\text { - } \text { alteração da qualidade do ar, água e } \\
\text { solo }\end{array}$ \\
\hline - emissão de efluentes sanitários & - alteração da qualidade da água \\
\hline - resíduos industriais & - alteração da qualidade do solo \\
\hline - risco de incêndio/explosão & $\begin{array}{l}\text { - alteração da qualidade do ar } \\
\text { - danos à saúde do ser humano }\end{array}$ \\
\hline
\end{tabular}




\subsubsection{O Diagrama de Fluxo do Processo de Laminação}

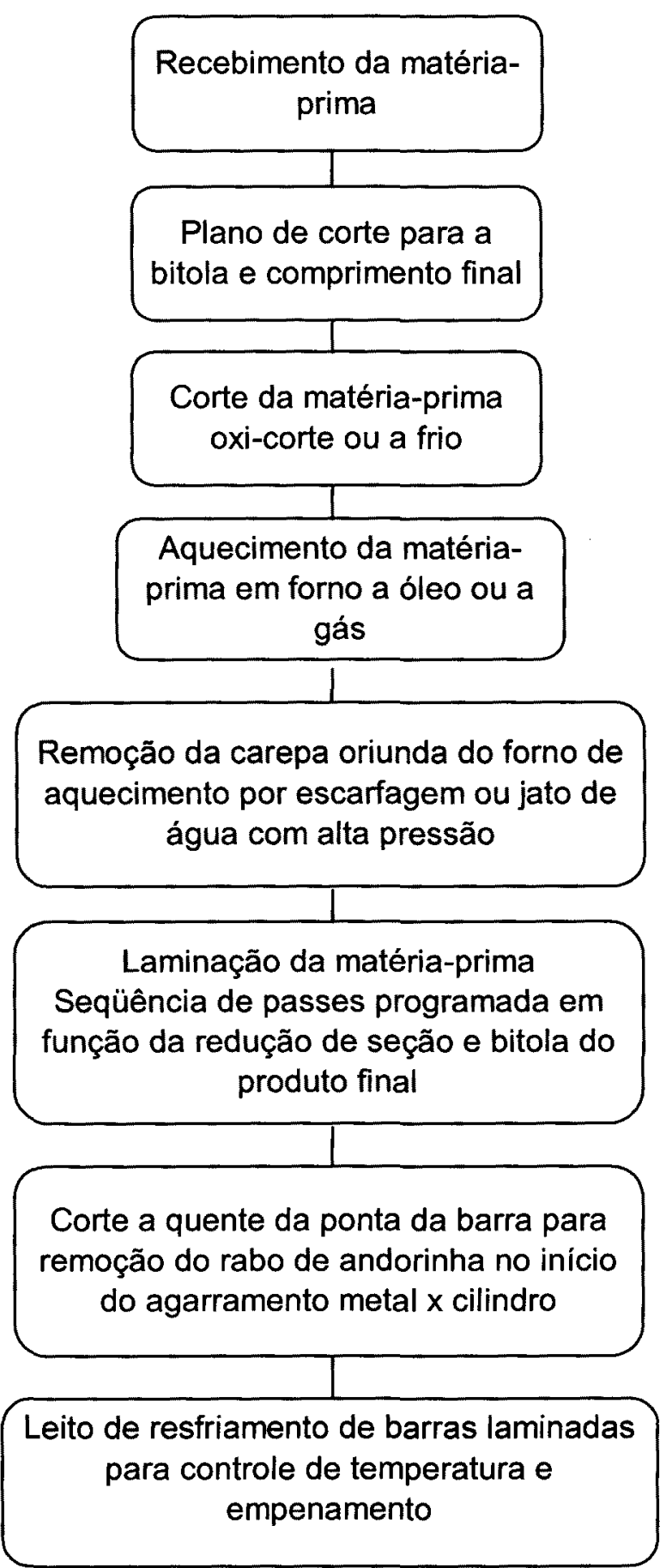




\subsection{Planejamento da Pesquisa}

Essencialmente, pesquisa visa a produção de conhecimento novo, que deve ser relevante teórica e socialmente e fidedigno. Dessa forma, pesquisa é sempre um elo entre o pesquisador e a comunidade científica, razão pela qual sua publicidade é elemento indispensável do processo de produção do conhecimento (Luna 2002, p. 24). Uma boa pesquisa exploratória se faz com questionário e/ou entrevista.

Para Ander-Egg, o questionário vem a ser "um procedimento em que as respostas são formuladas por escrito e não requer a presença do entrevistador".

A entrevista é o nome genérico no qual incluiremos diferentes abordagens que podem ser decompostas em: entrevista aberta, estruturada ou semi-estruturada. Pela sua importância, o trabalho de campo tem de ser pensado a partir de referenciais teóricos e também de aspectos operacionais que envolvem questões conceituais.

Kahn e Cannell oferecem-nos a seguinte definição para o que denominam "entrevista de pesquisa": "conversa a dois", feita por iniciativa do entrevistador, destinada a fornecer informações pertinentes para um objeto de pesquisa e entrada (pelo entrevistador) em temas igualmente pertinentes com vistas a este objetivo. Minayo 1999, p. 108.

O esquema da figura 27 detalha a seqüência de decisões no planejamento da pesquisa que foi adotado como modelo para o desenvolvimento desta dissertação.

\subsection{Métodos}

\subsubsection{Natureza da Pesquisa}

Os métodos aplicados nesse estudo foram desenvolvidos mediante a utilização da pesquisa exploratória, pesquisa bibliográfica da literatura disponível sobre $o$ assunto, preferencialmente dos últimos dez anos, de fonte direta, de questionário semi aberto, de entrevistas com os gestores de SMS das industrias siderúrgicas no Brasil e de consultas nos bancos de dados de centros de pesquisas e de instituições ligadas à área de saúde, meio ambiente e segurança do trabalho. 


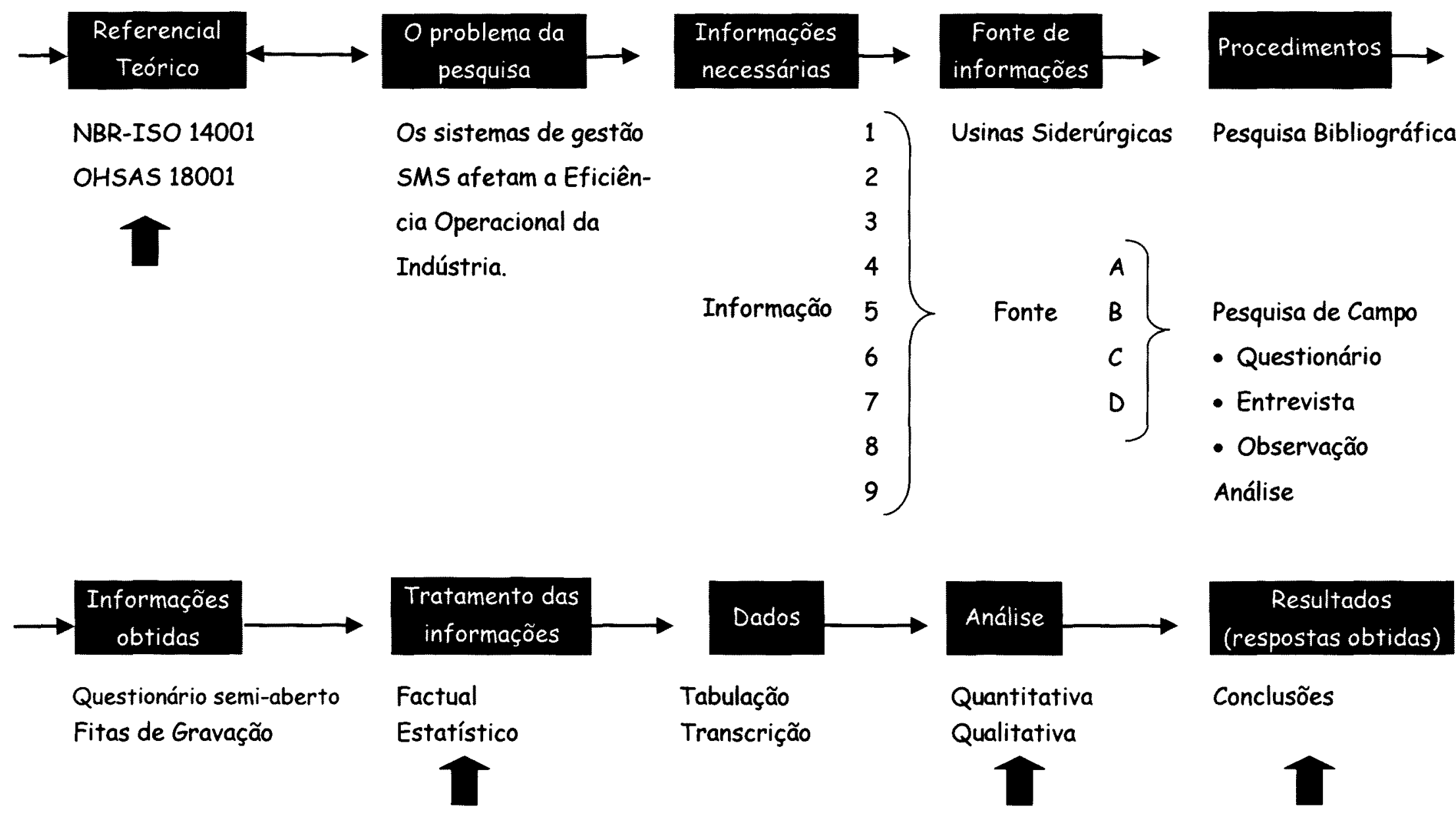

Figura 27 - Esquematização da Seqüência de Decisões no Planejamento da Pesquisa

Fonte: Adaptação; Luna 2002, p. 78 


\subsubsection{Fonte de Dados Utilizados}

Os dados referentes à situação atual dos recursos naturais no Brasil foram obtidos junto ao Ministério de Meio Ambiente (MMA) no relatório de estratégias de elaboração e implementação da Agenda 21 Brasileira, que é um programa de ação baseado num documento de 40 capítulos, constituindo a mais ousada e abrangente tentativa já realizada de promover, em escala planetária, um novo padrão de desenvolvimento, conciliando métodos de proteção ambiental, justiça social e eficiência econômica.

Os números de acidentes do trabalho no Brasil foram levantados pela internet, através da pesquisa no site do Ministério da Previdência e Assistência Social (MPAS) que não individualiza as empresas siderúrgicas no Brasil.

Os dados da pesquisa exploratória foram levantados através do questionário e do roteiro de entrevista, com três (3) indústrias siderúrgicas totalizando a produção de 3.175 .000 toneladas que representa aproximadamente $42 \%$ do mercado.

\subsubsection{Técnicas utilizadas na Pesquisa}

Na confecção do instrumento de pesquisa foram avaliados os seguintes aspectos:

- A formulação de perguntas para a investigação do problema da pesquisa.

- As informações necessárias para o encaminhamento das respostas às perguntas formuladas.

- A seleção das melhores fontes de informações.

- A necessidade da elaboração do questionário de pesquisa semi-estruturado.

- O roteiro da entrevista.

Primeiramente o questionário da pesquisa encaminhado para pré-teste a título experimental a uma das empresas participantes, antes da sua utilização de fato, para a verificação da adequação e entendimento sobre a abordagem do assunto. Após modificações e ajustes na forma de apresentação das perguntas (fechadas), o questionário foi aprovado como uma das ferramentas de coleta de informações e de dados. 
O questionário foi dividido em quatro (4) partes:

$1^{\text {a }}$ parte: Dados da empresa.

2 ${ }^{\mathrm{a}}$ parte: Principais fatores de SMS que afetam a eficiência operacional da indústria.

$3^{\mathbf{a}}$ parte: Principais beneficios e dificuldades na implantação e na manutenção de sistemas de gestão SMS.

$4^{\mathrm{a}}$ parte: Principais indicadores de SMS que medem a eficiência operacional da indústria.

O questionário foi encaminhado via correio eletrônico-email para a diretoria das empresas selecionadas na amostragem, juntamente com uma carta de apresentação com a explicação dos propósitos da pesquisa e uma carta de declaração de confidencialidade para a garantia do sigilo das informações disponibilizadas. Através de contato telefônico discutiu-se com os gestores de SMS das três (3) indústrias siderúrgicas selecionadas sobre a clareza e a forma de preenchimento do questionário.

As perguntas fechadas exigiam que os itens fossem relacionados pelos gestores de SMS em ordem crescente de importância para identificar quais são os principais fatores de SMS que afetam a eficiência operacional.

Os gestores de SMS poderiam acrescentar ou suprimir os fatores de SMS e atribuíram pontos aos itens de avaliação apresentados no questionário até que a soma atinja cem (100).

As respostas do questionário foram coletadas sem a presença do pesquisador, tabuladas através da média aritmética da pontuação das três (3) indústrias participantes e apresentadas na forma de Gráficos de Pareto.

O questionário apresentava as palavras vantagens e desvantagens que foram substituídas pelas palavras beneficios e dificuldades por sugestão de dois dos três gestores de SMS e foi aceita pelo pesquisador para melhoria do enfoque e aplicação do tema.

O roteiro da entrevista foi realizado através de visita técnica do pesquisador nas plantas industriais das empresas participantes da pesquisa e englobou as seguintes etapas: 
- Autorização da diretoria para a realização da pesquisa de campo.

- Explicações dos propósitos e dos métodos da pesquisa para o representante da empresa.

- Aplicação do roteiro da entrevista com perguntas e respostas sobre o tema.

- Gravação da entrevista feita pelo pesquisador com os gestores de SMS das empresas.

- Transcrição das gravações realizadas.

- Análise qualitativa das respostas.

- Tabulação das respostas de cada indústria participante.

- Comentários dos representantes das empresas pesquisadas.

As entrevistas com os gestores de SMS das três (3) indústrias siderúrgicas selecionadas foram realizadas seguindo um roteiro com vinte e seis (26) perguntas sobre os sistemas de SMS.

As entrevistas foram concedidas nas plantas industriais de atuação dos gestores de SMS. A conversa realizada a dois na forma de perguntas e respostas foi gravada e transcrita.

As respostas dos gestores de SMS das três indústrias pesquisadas A, B e C foram coletadas e apresentadas na forma de quadro, seguindo o modelo do ciclo PDCA proposto no planejamento da pesquisa.

O roteiro da entrevista foi dividido em seis (6) partes:

$1^{\text {a }}$ parte: Dados da empresa.

$2^{\mathrm{a}}$ parte: Planejamento do SMS.

$3^{\text {a }}$ parte: Implantação e manutenção do SMS.

$4^{\mathrm{a}}$ parte: Avaliação do SMS.

$5^{\mathrm{a}}$ parte: Análise crítica do SMS.

$6^{a}$ parte: Comentários finais dos gestores de SMS.

A entrevista explorou o tema da pesquisa e as perguntas elaboradas tiveram como finalidade a troca de informações, esclarecimentos sobre o assunto e a verificação do estágio de desenvolvimento dos sistemas de gestão de saúde, meio ambiente e 
segurança do trabalho das indústrias siderúrgicas no Brasil. Os entrevistados possuem larga experiência profissional e, portanto, houve pouca influência nas suas respostas, em razão da atuação deles em uma ou outra indústria. Procurou-se extrair a opinião do técnico frente a uma situação.

A pesquisa bibliográfica foi focada em dissertações e teses produzidas na USP, em livros e artigos científicos indicados na referência bibliográfica dos trabalhos consultados, das disciplinas oferecidas na pós-graduação, através de sites da internet e o conhecimento adquirido sobre o assunto através da pesquisa junto às empresas.

Foi considerado no levantamento bibliográfico, a produção dos centros de pesquisa e instituições ligadas à área de saúde, meio ambiente e segurança do trabalho, destacando-se: ISO da Suiça; BSI e ICI da Inglaterra; SAI e PEERCENTER dos Estados Unidos da América; ABNT, CETESB, FUNDACENTRO, IBAMA, MPAS, ABIQUIM e IBS do Brasil. A pesquisa englobou normas nacionais e internacionais, visitas em centros de pesquisa, instituições e indústrias.

\subsubsection{Delimitação do Universo}

A população alvo para essa pesquisa está formada pela indústria siderúrgica brasileira de produtos laminado longos, composto de treze (13) empresas associadas ao Instituto Brasileiro de Siderurgia - IBS com uma produção de laminados para vendas em 2002 de 7.624 .000 toneladas (Tabela 2), ou seja, 40,1\% de participação no mercado brasileiro. A laminação de produtos planos representa 59,9\% que corresponde a uma produção de 11.408 .000 toneladas, sendo no total a produção brasileira de laminados de 19.032.000 toneladas de acordo com fontes do IBS/2003. 
Tabela 2 - Produção de Laminados Não Planos

\begin{tabular}{lcccccc} 
& & & \multicolumn{3}{c}{ unidade: $1.000 \mathrm{t}$} \\
\hline \multicolumn{1}{c}{ Produtos Longos } & $\mathbf{1 9 9 7}$ & $\mathbf{1 9 9 8}$ & $\mathbf{1 9 9 9}$ & $\mathbf{2 0 0 0}$ & $\mathbf{2 0 0 1}$ & $\mathbf{2 0 0 2}$ \\
\hline Lingotes, Blocos e Tarugos * & 2.241 & 1.899 & 1.708 & 2.001 & 1.780 & 1.958 \\
Barras & 1.053 & 1.002 & 1.098 & 1.165 & 1.229 & 1.242 \\
Fio-Máquina & 2.097 & 2.011 & 2.285 & 2.476 & 2.523 & 2.599 \\
Vergalhões & 2.317 & 2.284 & 2.453 & 2.379 & 2.602 & 2.658 \\
Tubos sem costura & 343 & 293 & 305 & 423 & 462 & 442 \\
Perfis & 348 & 457 & 531 & 556 & 607 & 669 \\
Trilhos e acessórios & - & - & - & 1 & 2 & 14 \\
\hline TOTAL & $\mathbf{6 . 1 5 8}$ & $\mathbf{6 . 0 4 7}$ & $\mathbf{6 . 6 7 2}$ & $\mathbf{7 . 0 0 0}$ & $\mathbf{7 . 4 2 5}$ & $\mathbf{7 . 6 2 4}$ \\
\hline
\end{tabular}

* Excluído do total para evitar dupla contagem

Fonte : IBS, 2003

\subsubsection{Seleção da Amostra e Tipo de Amostragem}

O plano de amostragem por atributo foi desenvolvido durante a segunda guerra mundial e publicado pelo U.S. Government em 1963. A MIL-STD 105 apresenta amostragem atenuada, normal e severa. A tabela 3 abaixo estabelece o tamanho da amostra adotada na pesquisa.

Tabela 3 - Plano de Amostragem

\begin{tabular}{cc}
\hline \multicolumn{2}{c}{ AMOSTRAGEM NORMAL } \\
\hline População & Tamanho da Amostra \\
\hline 2 a 8 & 2 \\
9 a 15 & 3 \\
16 a 25 & 5 \\
26 a 50 & 8 \\
\hline
\end{tabular}

Fonte: Banks 1989, p. 346 
As unidades de laminação de aços não planos das três siderúrgicas selecionadas têm cerca de 6.000 colaboradores. Possui uma capacidade de produção de aproximadamente 1.800 .000 ton./ano e atuam a mais de cinqüenta (50) anos no Brasil com participação no mercado nacional e internacional.

Os gestores de SMS possuem no mínimo dezoito (18) anos de experiência profissional e trabalham com sistemas integrados de gestão de saúde, meio ambiente e segurança do trabalho.

\subsubsection{Limitações dos Métodos da Pesquisa}

O estudo está sujeito à existência de viés nas respostas dos gestores de SMS seja pelo seu nível de conhecimento sobre o tema ou pelo estágio do SMS da empresa. Para minimizar o viés da pesquisa, além do questionário, optou-se pela entrevista com os gestores de SMS; e na escolha da amostra buscou-se as empresas com a certificação por organismos internacionais, nas normas de Sistemas de Gestão ISO 14001 e OHSAS 18001 ou BS 8800.

\subsubsection{Seleção das Amostras}

A tabela da MIL-STD 105 apresenta para uma população igual a treze (13) um tamanho de amostra igual a três (3). O critério utilizado na seleção da amostra foi a escolha das usinas siderúrgicas que detém uma porcentagem elevada do mercado, permitindo conhecer o estado da arte nesse ramo de atividade, empresas com certificados ISO 14001 e OHSAS 18001 ou BS 8800 e por essa razão a facilidade de acesso para a obtenção de dados. Então foram feitos contatos telefônicos com os gestores de SMS das usinas siderúrgicas, através do qual foram expostos a importância e objetivo da pesquisa como argumento para a participação da indústria.

\subsubsection{Meios para a Coleta dos Dados de Campo}

a) Questionário a ser preenchido pelos gestores de SMS da indústria com perguntas abertas e fechadas. 
b) Roteiro para entrevista com os gestores de SMS da indústria e gravação das respostas para a coleta de dados suplementares.

O roteiro da entrevista foi elaborado com base no questionário e objetivo da pesquisa, com a finalidade de compreender como funciona o SMS da empresa.

\subsubsection{Validação do Questionário e do Roteiro da Entrevista}

Antes de coletar os dados nas indústrias selecionadas, o questionário e o roteiro da entrevista foram testados em uma das empresas que atua com o SMS implementado desde 2000 .

O questionário foi testado para verificar se as perguntas selecionadas eram adequadas e suficientes para o desenvolvimento do tema proposto.

$O$ roteiro da entrevista foi testado para complementar a abrangência $e$ profundidade da pesquisa e facilitar o entendimento dos fatores que afetam a eficiência operacional da indústria.

Essa verificação fez com que perguntas fossem acrescidas ao questionário e ao roteiro da entrevista.

\subsubsection{Coleta de Dados na Indústria Selecionada}

Em reunião com representantes da indústria selecionada, foram expostos os objetivos, as etapas da pesquisa e a declaração de confidencialidade, na qual se estabeleceu o compromisso de que os dados levantados seriam utilizados única e exclusivamente para a pesquisa, sendo mantido sigilo da identificação da empresa. 


\section{RESULTADOS E DISCUSSÕES}

Serão tratados de modo quantitativo e qualitativo os dados obtidos na pesquisa de campo através do questionário e entrevista com os gestores de SMS das três (3) indústrias siderúrgicas.

\subsection{Resultados da Pesquisa de Campo}

As respostas das três (3) indústrias pesquisadas A, B e C foram tabuladas e em seguida calculou-se a média aritmética e daí a porcentagem (\%) de cada item de avaliação. O resultado está apresentado na forma de Gráfico de Pareto.

Gráfico 1 - Principais Fatores Positivos de SMS que afetam a Eficiência Operacional da Indústria Siderúrgica no Brasil.

Gráfico 2 - Principais Fatores Negativos de SMS que afetam a Eficiência Operacional da Indústria Siderúrgica no Brasil.

Gráfico 3 - Principais Benefícios da Implantação de SMS.

Gráfico 4 - Principais Benefícios da Manutenção de SMS.

Gráfico 5 - Principais Dificuldades da Implantação de SMS.

Gráfico 6 - Principais Dificuldades da Manutenção de SMS.

Gráfico 7 - Principais Indicadores de SMS que medem a Eficiência Operacional da Indústria Siderúrgica no Brasil.

Gráfico 7.1 - Indicador de Material.

Gráfico 7.2 - Indicador de Capital Humano.

Gráfico 7.3 - Indicador de Energia.

Gráfico 7.4 - Indicador Financeiro.

Gráfico 7.5 - Indicador das Condições Ambientais.

Gráfico 7.6 - Indicador de Gestão SMS.

As perguntas abertas exploram a análise de como os principais fatores de SMS afetam a eficiência operacional, através das respostas dos gestores de SMS 
apresentadas no questionário da pesquisa. O resultado está transcrito nos Quadros 11 e 12.

Quadro 11 - Como os Fatores Positivos de SMS afetam a Eficiência Operacional da Indústria Siderúrgica no Brasil.

Quadro 12 - Como os fatores Negativos de SMS afetam a Eficiência Operacional da Indústria Siderúrgica no Brasil.

No Quadro 13 é apresentado o resultado da entrevista com os gestores de SMS.

No Quadro 14 é apresentado a significância dos itens avaliados e no Quadro 15 é apresentado o resultado da pesquisa sobre os principais indicadores de SMS da indústria siderúrgica.

Quadro 13 - Entrevista com os gestores de SMS.

Quadro 14 - Nível de Significância.

Quadro 15 - Principais indicadores de SMS da Indústria Siderúrgica. 


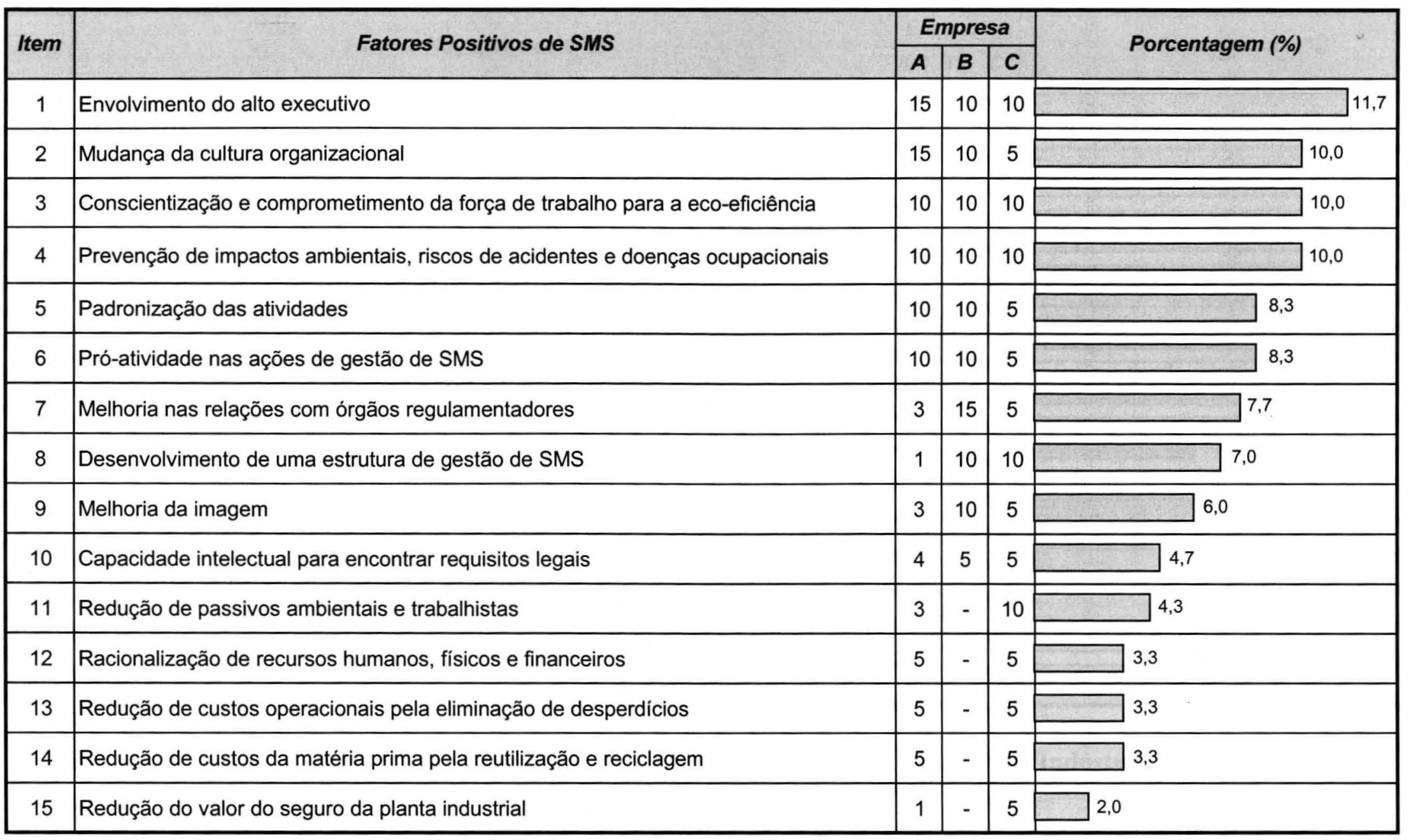

Gráfico 1 - Principais Fatores Positivos de SMS que afetam a Eficiência Operacional da Indústria Siderúrgica no Brasil 


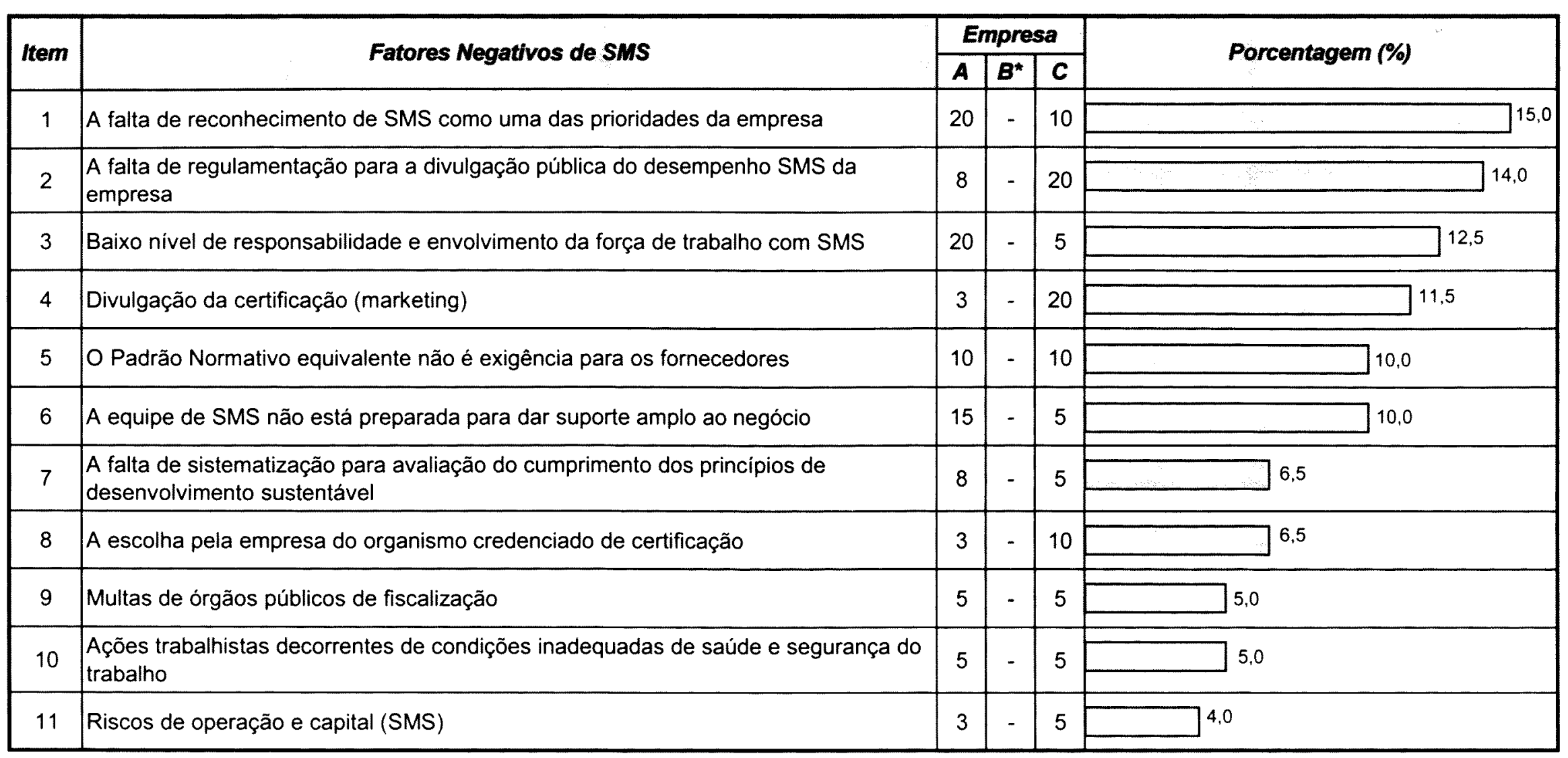

Gráfico 2 - Principais Fatores Negativos de SMS que afetam a Eficiência Operacional da Indústria Siderúrgica no Brasil

* A empresa B considerou que não existem fatores negativos de SMS 


\begin{tabular}{|c|c|c|c|c|c|}
\hline \multirow{2}{*}{ Item } & \multirow{2}{*}{ Beneficios da Implantaçáo de SMS } & \multicolumn{3}{|c|}{ Empresa } & \multirow{2}{*}{ Porcentagem (\%) } \\
\hline & & $\boldsymbol{A}$ & B & C & \\
\hline 1 & $\begin{array}{l}\text { Conformidade com os requisitos da empresa, legais, estatutários e } \\
\text { regulamentares }\end{array}$ & 15 & 10 & 20 & $\square 15,0$ \\
\hline 2 & Envolvimento do pessoal operacional & 10 & 15 & 10 & 111,7 \\
\hline 3 & Integração de políticas, programas e procedimentos & 10 & 10 & 10 & 10,0 \\
\hline 4 & Posição estratégica clara para o mercado & 10 & 10 & 10 & 10,0 \\
\hline 5 & Levantamento sistematizado do histórico de problemas & 10 & 10 & 10 & 10,0 \\
\hline 6 & O nivel gerencial é responsável pela efetividade da implantação de SMS & 10 & 10 & 10 & ] 10,0 \\
\hline 7 & Ciclo de retroalimentação e mecanismos de avaliação de SMS & 10 & 10 & 10 & 10,0 \\
\hline 8 & Os sistemas de gestão representam as práticas da empresa & 15 & 5 & 10 & ] 10,0 \\
\hline 9 & Melhoria nas relações com órgãos públicos & 5 & 10 & 5 & 6,7 \\
\hline 10 & Intangiveis & 5 & 10 & 5 & 6,7 \\
\hline
\end{tabular}

\section{Gráfico 3 - Principais Benefícios da Implantação de SMS}




\begin{tabular}{|c|c|c|c|c|c|}
\hline \multirow{2}{*}{ Item } & \multirow{2}{*}{ Beneficios da Manutençáo de SMS } & \multicolumn{3}{|c|}{ Empresa } & \multirow{2}{*}{ Porcentagem (\%) } \\
\hline & & $\bar{A}$ & B & c & \\
\hline 1 & Influencia os valores e visão da empresa & 20 & 15 & 10 & $\exists 15,0$ \\
\hline 2 & Auxilia a empresa a alcançar seus objetivos e metas & 10 & 10 & 20 & 13,3 \\
\hline 3 & Incentiva programas de melhoria e economia de energia nos processos & 5 & 10 & 20 & $\square 11,7$ \\
\hline 4 & Cria um espírito de auto disciplina & 15 & 10 & 10 & $\square 11,7$ \\
\hline 5 & $\begin{array}{l}\text { Norteia as atividades pelos princípios de atuação responsável e } \\
\text { desenvolvimento sustentável }\end{array}$ & 15 & 10 & 10 & 11,7 \\
\hline 6 & Compromisso com a melhoria contínua & 10 & 15 & 10 & 11,7 \\
\hline 7 & Auditoria de conformidade legal & 5 & 10 & 10 & 8,3 \\
\hline 8 & Define o que e como fazer nos assuntos de SMS & 15 & 10 & - & 8,3 \\
\hline 9 & Mudança no perfil tecnólogico da empresa & 5 & 5 & - & 3,3 \\
\hline 10 & Procedimentos adotados para análise laboratoriais & - & 5 & 5 & 3,3 \\
\hline
\end{tabular}

Gráfico 4 - Principais Benefícios da Manutenção de SMS 


\begin{tabular}{|c|c|c|c|c|c|c|}
\hline \multirow{2}{*}{ Item } & \multirow{2}{*}{ Dificuldades da Implantação de SMS } & \multicolumn{3}{|c|}{ Empresa } & \multirow{2}{*}{\multicolumn{2}{|c|}{ Porcentagem (\%) }} \\
\hline & & A & $B^{\star}$ & $c$ & & \\
\hline 1 & $\begin{array}{l}\text { É necessário grande aporte de conhecimento em um periodo de } \\
\text { tempo curto }\end{array}$ & 25 & - & 20 & & $\square 22,5$ \\
\hline 2 & Custo elevado & 10 & - & 20 & ] 15,0 & \\
\hline 3 & Sistema formal documentado em detalhe & 10 & - & 20 & 15,0 & \\
\hline 4 & Falta de experiência da equipe de SMS & 20 & - & 10 & 15,0 & \\
\hline 5 & $\begin{array}{l}\text { Elaboração de documentos normativos sem a participação da } \\
\text { força de trabalho }\end{array}$ & 15 & - & 10 & 12,5 & \\
\hline 6 & Resistência a mudanças & 10 & - & 10 & 10,0 & \\
\hline 7 & Terminologia e documentos de difícil entendimento & 5 & - & 10 & 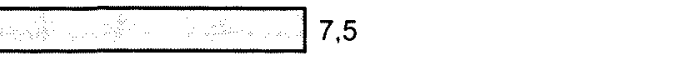 & \\
\hline 8 & Múltiplas fontes de informações & 5 & - & 10 & 7.5 & \\
\hline
\end{tabular}

\section{Gráfico 5 - Principais Dificuldades da Implantação de SMS}

* A empresa B considerou que não existem desvantagens na implantação de SMS 


\begin{tabular}{|c|c|c|c|c|c|}
\hline \multirow{2}{*}{ Item } & \multirow{2}{*}{ Dificuldades da Manutenção de SMS } & \multicolumn{3}{|c|}{ Empresa } & \multirow{2}{*}{ Porcentagem (\%) } \\
\hline & & A & B & C & \\
\hline 1 & $\begin{array}{l}\text { O comprometimento dos colaboradores perde força, se não houver } \\
\text { retroalimentação pela alta direção }\end{array}$ & 20 & 15 & 20 & $\square 18,3$ \\
\hline 2 & $\begin{array}{l}\text { A equipe de SMS possui responsabilidade sem o nivel de autoridade } \\
\text { equivalente }\end{array}$ & 10 & 10 & 20 & 13,3 \\
\hline 3 & O fluxo de informações não assegura agilidade e confiabilidade & 5 & 10 & 20 & $\square 11,7$ \\
\hline 4 & A politica de SMS não é realista & 15 & 15 & 5 & 11,7 \\
\hline 5 & $\begin{array}{l}\text { A equipe operacional não está alinhada com os objetivos e metas da } \\
\text { organização }\end{array}$ & 15 & 10 & 10 & $\square 11,7$ \\
\hline 6 & As diretrizes e responsabilidades não são claramente comunicadas & 15 & 10 & 5 & \begin{tabular}{|l|} 
\\
\end{tabular} 10,0 \\
\hline 7 & Falta de especialistas para a melhoria de SMS & 10 & 5 & 5 & 6,7 \\
\hline 8 & Elevado número de auditorias voluntária ou compulsória & 5 & 10 & 5 & 6,7 \\
\hline 9 & Custo elevado & 5 & 10 & 5 & \begin{tabular}{|l|} 
\\
\end{tabular} \\
\hline 10 & O calendário de eventos institucionais não é oficializado & - & 5 & 5 & 3,3 \\
\hline
\end{tabular}

Gráfico 6 - Principais Dificuldades da Manutenção de SMS 


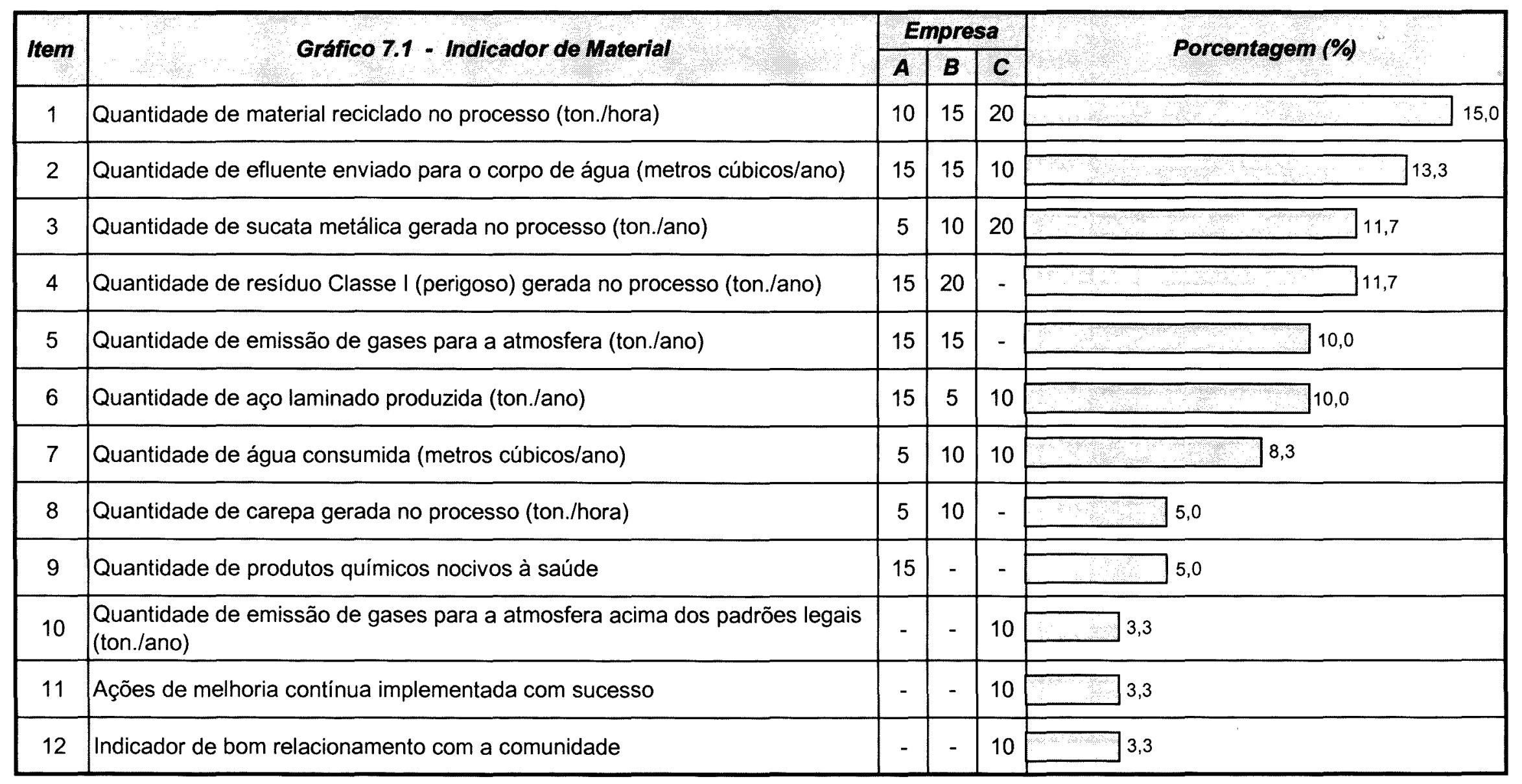

Gráfico 7 - Principais Indicadores de SMS que medem a Eficiência Operacional da Indústria Siderúrgica no Brasil 


\begin{tabular}{|c|c|c|c|c|c|}
\hline \multirow{2}{*}{ Item } & \multirow{2}{*}{ Gráfico 7.2 - Indicador de Capital Humano } & \multicolumn{3}{|c|}{ Empresa } & \multirow{2}{*}{ Porcentagem (\%) } \\
\hline & & $\boldsymbol{A}$ & B & C & \\
\hline 1 & Número de hora/homem de treinamento por ano (mão de obra direta) & 20 & 10 & 10 & $\square 13,3$ \\
\hline 2 & Número de sugestões de SMS propostas por colaborador por ano & 5 & 15 & 20 & ]13,3 \\
\hline 3 & Investimento em capacitação profissional & 20 & 10 & 10 & $\square 13,3$ \\
\hline 4 & Número de colaboradores com qualificação ou certificação profissional & 20 & 10 & 10 & $\square 13,3$ \\
\hline 5 & Grau de escolaridade dos colaboradores & 10 & 10 & 10 & $\square 10,0$ \\
\hline 6 & Número de programas de SMS por ano & 5 & 10 & 10 & 8,3 \\
\hline 7 & Número de participantes em programas de SMS por ano (mão de obra direta) & 5 & 10 & 10 & +2 \\
\hline 8 & Número de colaboradores que conhece e pratica a política de SMS da empresa & 5 & 10 & 10 & 8,3 \\
\hline 9 & Número de colaboradores com a formação de auditor interno & - & 10 & 10 & 6,7 \\
\hline 10 & Tempo de experiência na função & 10 & 5 & - & 5,0 \\
\hline
\end{tabular}

Gráfico 7 - Principais Indicadores de SMS que medem a Eficiência Operacional da Indústria Siderúrgica no Brasil - cont. 


\begin{tabular}{|c|l|c|c|c|c|}
\hline \multirow{2}{*}{ Item } & \multicolumn{2}{|c|}{ Gráffico 7.3 - Indicador de Energia } & \multicolumn{2}{|c|}{ Empresa } & Porcentagem (\%) \\
\cline { 3 - 6 } & & A & B & C & \\
\hline 1 & Quantidade de energia elétrica consumida (Kwh / ano) & 50 & 25 & 20 & \\
\hline 2 & $\begin{array}{l}\text { Quantidade de gás (natural, GLP, oxigênio, acetileno, etc.) } \\
\text { consumida (metros cúbicos/ano) }\end{array}$ & 25 & 25 & 20 & \\
\hline 3 & $\begin{array}{l}\text { Quantidade de combustivel (óleo, gasolina, querosene, } \\
\text { etc.) consumida (litro/ano) }\end{array}$ & 25 & 25 & 20 & \\
\hline 4 & Quantidade de coque metalúrgico consumido (ton./ano) & - & 25 & - & \\
\hline 5 & Quantidade de água adquirida (metros cúbicos/ano) & - & - & 20 & \\
\hline 6 & Quantidade de insumo no processo (ton./ano) & - & - & 20 & \\
\hline
\end{tabular}

Gráfico 7 - Principais Indicadores de SMS que medem a Eficiência Operacional da Indústria Siderúrgica no Brasil - cont. 


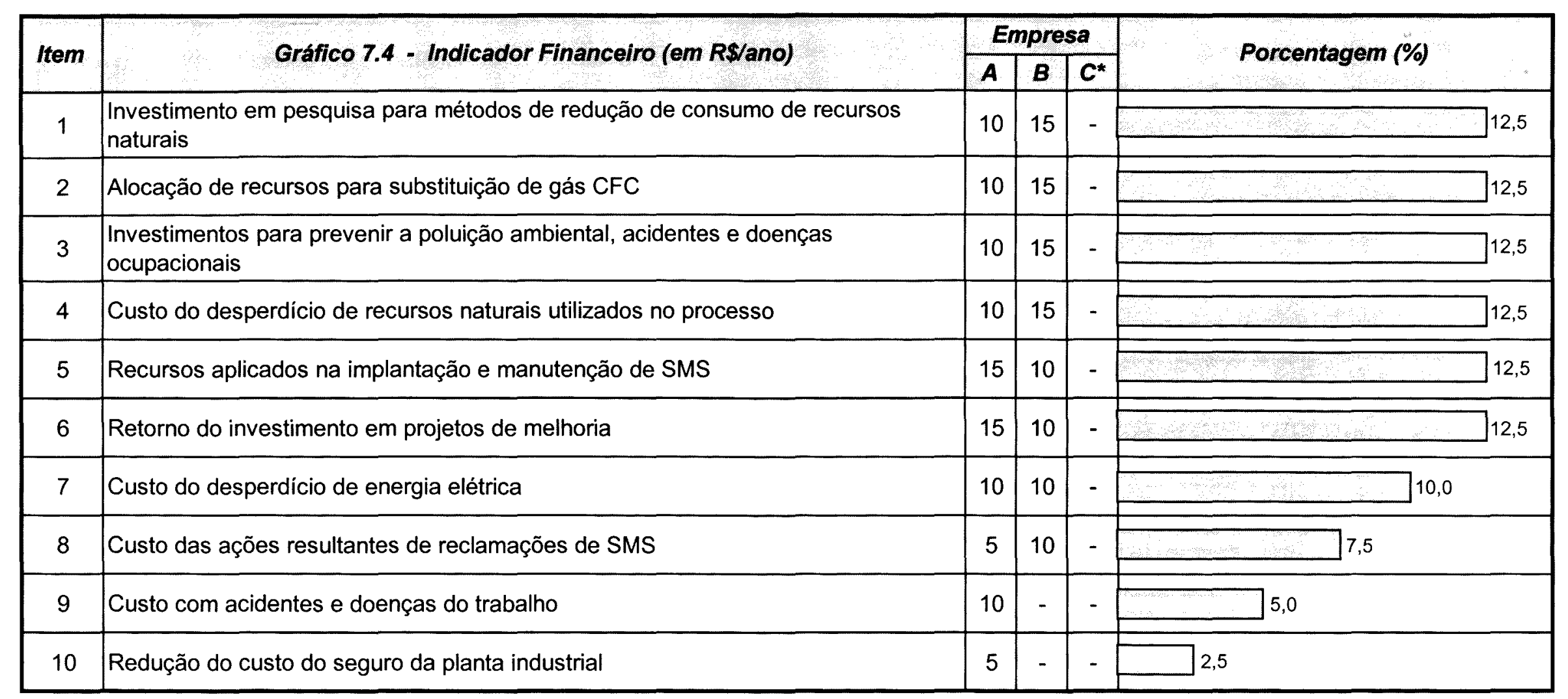

Gráfico 7 - Principais Indicadores de SMS que medem a Eficiência Operacional da Indústria Siderúrgica no Brasil - cont.

* não opinou. 


\begin{tabular}{|c|c|c|c|c|c|}
\hline \multirow{2}{*}{ Item } & \multirow{2}{*}{ Gráfico 7.5 - Indicador das Condiçōes Ambientais } & \multicolumn{3}{|c|}{ Empresa } & \multirow{2}{*}{ Porcentagem (\%) } \\
\hline & & A & B & C & \\
\hline 1 & Equipamentos com tecnologia de controle ambiental ( $\mathrm{N}^{\circ}$ Total) & 20 & 15 & 10 & $\beth 15,0$ \\
\hline 2 & $\begin{array}{l}\text { Número de horas de trabalho por ano, com manutenção preventiva em } \\
\text { equipamentos criticos para SMS }\end{array}$ & 15 & 15 & 10 & 13,3 \\
\hline 3 & $\begin{array}{l}\text { Número de aspectos e impactos ambientais significativos identificados e } \\
\text { gerenciados }\end{array}$ & - & 15 & 20 & 11,7 \\
\hline 4 & $\begin{array}{l}\text { Paralisações em horas por ano para atendimento das condições ambientais } \\
\text { exigidas para o processo }\end{array}$ & 5 & 15 & 10 & 10,0 \\
\hline 5 & Medição de ruído (valor máximo em dB(A)) & 15 & 5 & 10 & 10,0 \\
\hline 6 & Medição de calor (temperatura de trabalho em Graus Celsius) & 15 & 5 & 10 & 10,0 \\
\hline 7 & Medição de luminosidade (valor em Lux) & 15 & - & 10 & 8,3 \\
\hline 8 & Número de riscos e perigos significativos identificados e gerenciados & - & 15 & 10 & 2 \\
\hline 9 & $\begin{array}{l}\text { Número de acidentes e doenças ocupacionais por ano com ou sem } \\
\text { afastamento }\end{array}$ & 5 & 5 & 10 & 6,7 \\
\hline 10 & Número de acidentes por ano com vazamento de produtos perigosos & 5 & 5 & - & 3,3 \\
\hline 11 & $\begin{array}{l}\text { Número de atendimento à emergência por ano (incêndio, operação anormal, } \\
\text { etc.) }\end{array}$ & 5 & 5 & - & 3,3 \\
\hline
\end{tabular}

Gráfico 7 - Principais Indicadores de SMS que medem a Eficiência Operacional da Indústria Siderúrgica no Brasil - cont. 


\begin{tabular}{|c|c|c|c|c|c|}
\hline \multirow{2}{*}{ Item } & \multirow{2}{*}{ Gráfico 7.6 - Indicador de Gestão SMS } & \multicolumn{3}{|c|}{ Empresa } & \multirow{2}{*}{ Porcentagem (\%) } \\
\hline & & A & B & C & \\
\hline 1 & Investimento em ações de gestão SMS com melhoria no desempenho operacional & 20 & 10 & 10 & $\square 13,3$ \\
\hline 2 & Número de ações corretivas e preventivas implementadas por ano & 15 & 5 & 20 & ] 13,3 \\
\hline 3 & Redução de energia elétrica consumida por tonelada de aço produzida & 5 & 10 & 20 & 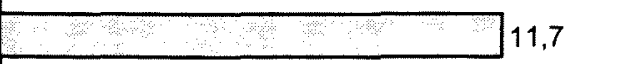 \\
\hline 4 & Número de objetivos e metas de SMS alcançados por ano & 15 & 10 & 10 & 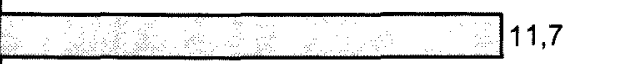 \\
\hline 5 & Número de simulados de planos de atendimento à emergência realizados por ano & 10 & 10 & 10 & $\square 10,0$ \\
\hline 6 & Redução do consumo de produtos químicos nocivos à saúde & 5 & 10 & 10 & 8,3 \\
\hline 7 & Número de fornecedores com o sistema de gestão SMS & 10 & 10 & - & 6,7 \\
\hline 8 & Veículos equipados com tecnologia de controle ambiental ( $\%$ da frota) & 10 & 5 & - & 5,0 \\
\hline 9 & Número de requisitos legais gerenciados pela empresa & - & 5 & 10 & 5,0 \\
\hline 10 & Redução do volume de gás consumido por tonelada de aço produzida & 5 & 10 & - & 5,0 \\
\hline 11 & Redução do volume de combustivel consumido por tonelada de aço produzida & 5 & 10 & - & 5,0 \\
\hline 12 & Número de auditorias de SMS realizadas por ano & - & 5 & 10 & 5,0 \\
\hline
\end{tabular}

Gráfico 7 - Principais Indicadores de SMS que medem a Eficiência Operacional da Indústria Siderúrgica no Brasil - cont. 


\section{Quadro 11 - Como os Fatores Positivos de SMS afetam a Eficiência} Operacional da Indústria Siderúrgica no Brasil

\begin{tabular}{|c|c|}
\hline Item & Fatores Positivos de SMS \\
\hline 1 & $\begin{array}{l}\text { É fundamental para definir o rumo da organização em direção à melhoria } \\
\text { do desempenho. É a alta direção que incentiva e proporciona os recursos } \\
\text { necessários para o desenvolvimento dos sistemas de gestão SMS. } \\
\text { Através da análise crítica do SMS e resultados das auditorias a alta direção } \\
\text { verifica as oportunidades de melhoria. }\end{array}$ \\
\hline 2 & $\begin{array}{l}\text { A conscientização de todos em relação à importância das questões de SMS } \\
\text { proporciona o envolvimento necessário para a melhoria do desempenho. }\end{array}$ \\
\hline 3 & Através da ordenação dos objetivos e metas. \\
\hline 4 & $\begin{array}{l}\text { Evita a ocorrência de não-conformidades, incidentes e acidentes. } \\
\text { Através do acompanhamento do desempenho. }\end{array}$ \\
\hline 5 & $\begin{array}{l}\text { Evita a realização de uma mesma atividade de forma diferenciada, } \\
\text { otimizando tempo, custos e prevenindo erros. } \\
\text { Melhoria da imagem interna e externa da empresa. }\end{array}$ \\
\hline 6 & $\begin{array}{l}\text { Evita a ocorrência de não-conformidades, incidentes e acidentes através do } \\
\text { planejamento das ações mitigadoras. }\end{array}$ \\
\hline 7 & $\begin{array}{l}\text { Através da atuação conjunta entre a empresa e órgãos de controle e } \\
\text { licenciamento e desenvolvimento de atividades que agregam valor para a } \\
\text { melhoria do desempenho e não mais para somente atuar como fiscalizador. }\end{array}$ \\
\hline 8 & $\begin{array}{l}\text { Através de gerenciamento de SMS, identificação das questões da saúde, } \\
\text { meio ambiente e segurança do trabalho e envolvimento de todos. }\end{array}$ \\
\hline 9 & $\begin{array}{l}\text { Os clientes preferem empresas com responsabilidade social em relação às } \\
\text { questões de SMS e melhor relacionamento com os órgãos de controle e } \\
\text { licenciamento. }\end{array}$ \\
\hline 10 & $\begin{array}{l}\text { Através da melhoria contínua o sistema de gestão SMS provê meios para o } \\
\text { atendimento dos requisitos legais. }\end{array}$ \\
\hline 11 & $\begin{array}{l}\text { Através da redução de custos e desenvolvimento tecnológico no tratamento } \\
\text { de resíduos. }\end{array}$ \\
\hline 12 & $\begin{array}{l}\text { Através da otimização de tempo, custos e melhoria nos aspectos de SMS } \\
\text { com conseqüente redução dos impactos (ações mitigadoras). }\end{array}$ \\
\hline 13 & $\begin{array}{l}\text { Através da otimização de tempo, custos e exigências aos parceiros de } \\
\text { comportamento ambiental correto. }\end{array}$ \\
\hline 14 & $\begin{array}{l}\text { Através da redução de custos e acesso com maior facilidade à certificação } \\
\text { ambiental. }\end{array}$ \\
\hline 15 & Através da redução de custos e planejamento de ações emergenciais. \\
\hline
\end{tabular}


Quadro 12 - Como os Fatores Negativos de SMS afetam a Eficiência Operacional da Indústria Siderúrgica no Brasil

\begin{tabular}{|c|c|}
\hline Item & Fatores Negativos de SMS \\
\hline 1 & $\begin{array}{l}\text { A eficiência operacional fica comprometida uma vez que o não } \\
\text { cumprimento das ações de SMS e os seus resultados podem trazer } \\
\text { conseqüências desastrosas. }\end{array}$ \\
\hline 2 & $\begin{array}{l}\text { Afeta a imagem pública da empresa em relação à sua responsabilidade } \\
\text { social, trazendo como conseqüência a redução das oportunidades de } \\
\text { negócio. }\end{array}$ \\
\hline 3 & $\begin{array}{l}\text { A implantação, a manutenção e a melhoria dos sistemas de gestão SMS } \\
\text { ficam comprometidos. } \\
\text { Idem a } 1 .\end{array}$ \\
\hline 4 & Idem a 2 . \\
\hline 5 & $\begin{array}{l}\text { Faz com que os fornecedores não tenham a mesma preocupação e } \\
\text { desempenho que a empresa busca em relação a SMS. }\end{array}$ \\
\hline 6 & $\begin{array}{l}\text { A concepção e desempenho dos sistemas de gestão SMS não trará } \\
\text { benefícios compensadores à empresa. }\end{array}$ \\
\hline 7 & Idem a 2 \\
\hline 8 & $\begin{array}{l}\text { A escolha de um organismo credenciado de certificação que não venha a } \\
\text { agregar valor para a empresa resulta em sistemas de gestão SMS que não } \\
\text { contribui para o desempenho operacional. }\end{array}$ \\
\hline 9 & $\begin{array}{l}\text { Trazem custos que podem alterar significativamente o resultado } \\
\text { operacional. }\end{array}$ \\
\hline 10 & Idem a 9. \\
\hline 11 & $\begin{array}{l}\text { O desconhecimento de riscos sobre SMS pode levar a resultados } \\
\text { desastrosos, incluindo autuações e multas de alto valor. }\end{array}$ \\
\hline
\end{tabular}


Quadro 13 - Entrevista com os Gestores de SMS

\begin{tabular}{|c|c|c|c|c|}
\hline $\begin{array}{l}\text { Ciclo } \\
\text { PDCA }\end{array}$ & Roteiro da Entrevista & Empresa A & Empresa B & Empresa C \\
\hline \multirow{6}{*}{ 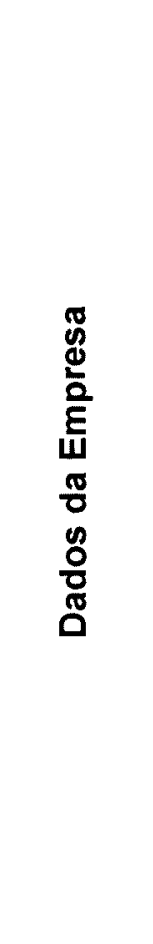 } & Capital Social & Nacional & Misto & Misto \\
\hline & Mercado & Nacional & Nacional e Internacional & Nacional e Internacional \\
\hline & $\begin{array}{l}\text { Motivos para a implantação } \\
\text { do SMS }\end{array}$ & $\begin{array}{l}\text { Incentivos oferecidos pelo } \\
\text { Governo }\end{array}$ & Competividade & $\begin{array}{l}\text { Liderança de mercado, } \\
\text { competividade e proteção ao } \\
\text { trabalhador }\end{array}$ \\
\hline & $\begin{array}{l}\text { O SMS é estendido aos } \\
\text { fornecedores e clientes? }\end{array}$ & $\begin{array}{l}\text { Sim. Atuação por influência junto } \\
\text { aos clientes }\end{array}$ & $\begin{array}{l}\text { Sim. Maior foco em } \\
\text { fornecedores }\end{array}$ & $\begin{array}{l}\text { Sim. Preferência de compra } \\
\text { aos fornecedores alinhados } \\
\text { com a politica da empresa }\end{array}$ \\
\hline & $\begin{array}{l}\text { Quais são as principais } \\
\text { contribuições da equipe de } \\
\text { SMS para a eficiência } \\
\text { operacional da empresa? }\end{array}$ & $\begin{array}{l}\text { Atuação com foco na redução de } \\
\text { custos }\end{array}$ & $\begin{array}{l}\text { - Treinamento } \\
\text { - Elaboração e revisão de } \\
\text { normas } \\
\text { - Auditorias internas e externas }\end{array}$ & $\begin{array}{l}\text { - Treinamentos } \\
\text { - Auditorias } \\
\text { - Estabelece procedimentos } \\
\text { - Gestão e monitoramento de } \\
\text { indicadores }\end{array}$ \\
\hline & SMS pró-ativo ou reativo & Reativo & Pró-ativo & Pró-ativo \\
\hline
\end{tabular}


Quadro 13 - Entrevista com os Gestores de SMS - cont.

\begin{tabular}{|c|c|c|c|c|}
\hline $\begin{array}{l}\text { Ciclo } \\
\text { PDCA }\end{array}$ & Roteiro da Entrevista & Empresa A & Empresa B & Empresa C \\
\hline \multirow{4}{*}{ 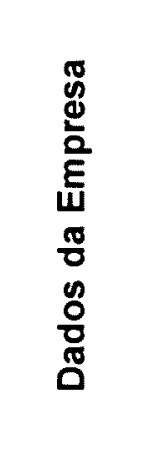 } & Sistema de Gestão Integrada & Sim. SGI & Sim. SGI & Sim. SIG \\
\hline & Planta Industrial & Brasil & Brasil e exterior & Brasil e exterior \\
\hline & $\begin{array}{l}\text { Nivel do SMS no Brasil em } \\
\text { relação a plantas industriais } \\
\text { no exterior }\end{array}$ & Não opinou & $\begin{array}{l}\text { O modelo do SGI passou a ser } \\
\text { referência para as empresas do } \\
\text { grupo no exterior }\end{array}$ & Nivel igual \\
\hline & $\begin{array}{l}\text { O SMS influencia nas } \\
\text { exportações? }\end{array}$ & Sim & Sim & Sim \\
\hline \multirow{2}{*}{$\begin{array}{l}\sum_{5}^{\infty} \\
\infty \\
0 \\
0 \\
0 \\
\stackrel{0}{0} \\
\stackrel{5}{0} \\
\frac{.0}{0} \\
\frac{\pi}{0} \\
\frac{\pi}{0}\end{array}$} & $\begin{array}{l}\text { Qual a importância do SMS } \\
\text { no planejamento estratégico? }\end{array}$ & $\begin{array}{l}\text { Definição da Missão, Visão, } \\
\text { Valores e Políticas }\end{array}$ & $\begin{array}{l}\text { Definição e desdobramento de } \\
\text { diretrizes para novos projetos e } \\
\text { rotina diária }\end{array}$ & Investimentos \\
\hline & Planejamento do SMS & $\begin{array}{l}\text { "Workshop" anual da diretoria e } \\
\text { gerentes }\end{array}$ & $\begin{array}{l}\text { Diretrizes da diretoria } \\
\text { Projetos de curto, médio e longo } \\
\text { prazo } \\
\text { Reuniões de análise critica pela } \\
\text { alta direção }\end{array}$ & $\begin{array}{l}\text { Reunião anual com objetivos e } \\
\text { metas }\end{array}$ \\
\hline
\end{tabular}


Quadro 13 - Entrevista com os Gestores de SMS - cont.

\begin{tabular}{|c|c|c|c|c|}
\hline $\begin{array}{l}\text { Ciclo } \\
\text { PDCA }\end{array}$ & Roteiro da Entrevista & Empresa A & Empresa B & Empresa C \\
\hline \multirow{2}{*}{ 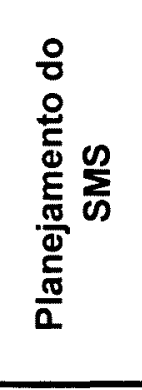 } & $\begin{array}{l}\text { Ferramentas de Gestão do } \\
\text { SMS }\end{array}$ & $\begin{array}{l}\text { - "Brainstorming" } \\
\text { - Diagrama de causa-e-efeito } \\
\text { - Ciclo PDCA }\end{array}$ & $\begin{array}{l}\text { - Método de análise e solução } \\
\text { de problemas-MASP } \\
\text { - Ciclo PDCA }\end{array}$ & $\begin{array}{l}\text { - Método de análise e solução } \\
\text { de problemas-MASP } \\
\text { - Ciclo PDCA }\end{array}$ \\
\hline & $\begin{array}{l}\text { Controle das Ações de } \\
\text { Gestão do SMS }\end{array}$ & - Auditorias & - Auditorias internas e externas & $\begin{array}{l}\text { - Relatório de desempenho } \\
\text { - Auditorias }\end{array}$ \\
\hline \multirow{2}{*}{ 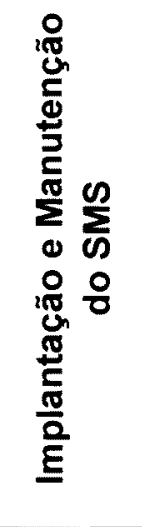 } & $\begin{array}{l}\text { "Benchmarking" (comparação } \\
\text { com as melhores práticas) }\end{array}$ & Não & $\begin{array}{l}\text { Sim. Indicadores de eco- } \\
\text { eficiência }\end{array}$ & Não \\
\hline & Programas de Gestão & $\begin{array}{l}\text { - Resíduos } \\
\text { - Recursos naturais (água e gás, } \\
\text { utilizados no processo industrial) } \\
\text { - Energia elétrica }\end{array}$ & $\begin{array}{l}\text { - Prestadores de serviços } \\
\text { - Descarte zero de efluentes } \\
\text { hídricos } \\
\text { - Resíduos sólidos ( } 50 \mathrm{~kg} \mathrm{de} \\
\text { resíduo/ton. produzida) }\end{array}$ & $\begin{array}{l}\text { - Conservação de energia } \\
\text { - Recursos naturais } \\
\text { - Crédito de oxigênio na } \\
\text { fabricação de gusa através de } \\
\text { carvão vegetal }\end{array}$ \\
\hline
\end{tabular}


Quadro 13 - Entrevista com os Gestores de SMS - cont.

\begin{tabular}{|c|c|c|c|c|}
\hline $\begin{array}{l}\text { Ciclo } \\
\text { PDCA }\end{array}$ & Roteiro da Entrevista & Empresa A & Empresa $\mathbf{B}$ & Empresa C \\
\hline \multirow{3}{*}{ 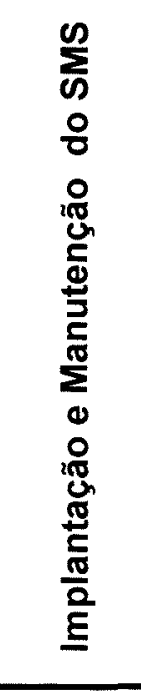 } & Programas de Gestão & $\begin{array}{l}\text { - Ergonomia } \\
\text { - Ginástica laboral }\end{array}$ & & $\begin{array}{l}\text { - Resíduos } \\
\text { - Ergonometria } \\
\text { - Ruído } \\
\text { - Campanhas de prevenção }\end{array}$ \\
\hline & $\begin{array}{l}\text { Desvios de requisitos } \\
\text { normativos }\end{array}$ & $\begin{array}{l}\text { - Atendimento à legislação } \\
\text { - Aspectos e impactos } \\
\text { ambientais } \\
\text { - Procedimentos e instruções de } \\
\text { trabalho }\end{array}$ & $\begin{array}{l}\text { Não foi observado desvios de } \\
\text { requisitos normativos nos } \\
\text { últimos dois (2) anos }\end{array}$ & - Atendimento à legislação \\
\hline & Código de ética & Não & Sim & Sim \\
\hline \multirow{2}{*}{ 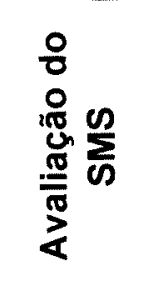 } & $\begin{array}{l}\text { Gerenciamento de } \\
\text { desempenho do SMS para o } \\
\text { público }\end{array}$ & Sim. Consultoria Jurídica & Sim & Sim \\
\hline & $\begin{array}{l}\text { Informações das mudanças } \\
\text { externas }\end{array}$ & $\begin{array}{l}\text { Sim. Quando solicitado pelas } \\
\text { partes interessadas }\end{array}$ & $\begin{array}{l}\text { Sim. Publicação do Balanço } \\
\text { Social e divulgação através dos } \\
\text { meios de comunicações }\end{array}$ & $\begin{array}{l}\text { Sim. Através do Setor de } \\
\text { Relações Públicas }\end{array}$ \\
\hline
\end{tabular}


Quadro 13 - Entrevista com os Gestores de SMS - cont.

\begin{tabular}{|c|c|c|c|c|}
\hline $\begin{array}{l}\text { Ciclo } \\
\text { PDCA }\end{array}$ & Roteiro da Entrevista & Empresa A & Empresa B & Empresa C \\
\hline \multirow[b]{2}{*}{ 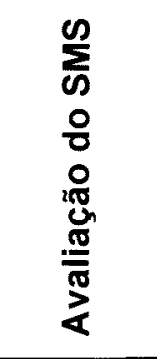 } & Auditorias integradas & Não & Sim & Sim \\
\hline & $\begin{array}{l}\text { Itens chaves para o sucesso } \\
\text { do SMS }\end{array}$ & $\begin{array}{l}\text { - Planejamento do SMS } \\
\text { - Estabelecimento de indicadores } \\
\text { - Ações de avaliação } \\
\text { - Ações de melhoria }\end{array}$ & $\begin{array}{l}\text { - Comprometimento da alta } \\
\text { direção }\end{array}$ & $\begin{array}{l}\text { - Conscientização das } \\
\text { pessoas } \\
\text { - Apoio da organização }\end{array}$ \\
\hline 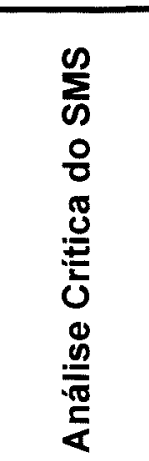 & Lições aprendidas & $\begin{array}{l}\text { "Nós somos capazes de muito } \\
\text { mais do que imaginamos" } \\
\text { (implementação do SMS) } \\
\text { "A chama acesa do SMS é o } \\
\text { trabalho de formiguinha das } \\
\text { pessoas" (manutenção do SMS) }\end{array}$ & $\begin{array}{l}\text { - Excesso de normas internas } \\
\text { (implantação do SMS) } \\
\text { - "Nós não temos que trabalhar } \\
\text { para o Sistema e sim, fazer com } \\
\text { que o Sistema trabalhe e busque } \\
\text { os resultados para nós" } \\
\text { (manutenção do SMS) }\end{array}$ & $\begin{array}{l}\text { - Refratariedade no } \\
\text { apontamento de situações não- } \\
\text { conformes (implantação do } \\
\text { SMS) } \\
\text { - Foco no cliente: O cliente é o } \\
\text { Rei (manutenção do SMS) }\end{array}$ \\
\hline
\end{tabular}


Quadro 13 - Entrevista com os Gestores de SMS - cont.

\begin{tabular}{|c|c|c|c|c|}
\hline $\begin{array}{l}\text { Ciclo } \\
\text { PDCA }\end{array}$ & Roteiro da Entrevista & Empresa A & Empresa B & Empresa C \\
\hline$\sum_{\substack{\infty \\
0}}^{\infty}$ & Equipe de SMS & $\begin{array}{l}\text { - Equipe de gestão da qualidade } \\
\text { e meio ambiente } \\
\text { - Equipe de SSO }\end{array}$ & $\begin{array}{l}\text { - Equipe da qualidade } \\
\text { - Especialista em meio ambiente } \\
\text { - Equipe de SSO }\end{array}$ & $\begin{array}{l}\text { - Especialista em qualidade } \\
\text { - Especialista em meio } \\
\text { ambiente } \\
\text { - Equipe operacional de SSO } \\
\text { - Engenherio institucional (que } \\
\text { trata das questões externas) }\end{array}$ \\
\hline 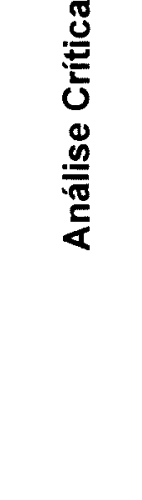 & Alocação de recursos & $\begin{array}{l}\text { - Implementação e manutenção } \\
\text { do SMS } \\
\text { - Atendimento à legislação } \\
\text { - Programas de gestão } \\
\text { - Objetivos e estratégias } \\
\text { - Análise crítica pela alta direção }\end{array}$ & $\begin{array}{l}\text { - Levantamento anual das } \\
\text { necessidades de investimentos } \\
\text { com as justificativas } \\
\text { - Aprovação da Gerência Geral } \\
\text { e Diretoria }\end{array}$ & $\begin{array}{l}\text { - Levantamento anual de } \\
\text { recursos para: } \\
\text { - Objetivos e metas } \\
\text { - Sistemas de informações } \\
\text { - Novos equipamentos } \\
\text { - Parcerias } \\
\text { - Especialistas } \\
\text { - Aprovação da } \\
\text { Superintendência e Diretoria }\end{array}$ \\
\hline
\end{tabular}


Quadro 13 - Entrevista com os Gestores de SMS - cont.

\begin{tabular}{|c|c|c|c|c|}
\hline $\begin{array}{l}\text { Ciclo } \\
\text { PDCA }\end{array}$ & Roteiro da Entrevista & Empresa A & Empresa B & Empresa C \\
\hline \multirow{3}{*}{ 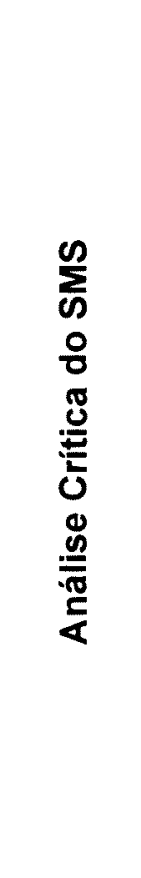 } & $\begin{array}{l}\text { Recursos do SMS x } \\
\text { faturamento }\end{array}$ & Não soube informar & Não soube informar & Não soube informar \\
\hline & Tendências do mercado & $\begin{array}{l}\text { - Exigência cada vez maior do } \\
\text { mercado } \\
\text { - Sistemas de gestão integrado } \\
\text { (qualidade, segurança e saúde, } \\
\text { meio ambiente e } \\
\text { responsabilidade social) } \\
\text { - Sistemas de gerenciamento de } \\
\text { risco }\end{array}$ & $\begin{array}{l}\text { - Implementação total dos } \\
\text { sistemas de gestão em todas as } \\
\text { empresas } \\
\text { - Daqui a três (3) anos não será } \\
\text { concebido ter nenhum parceiro } \\
\text { ou fornecedor sem a } \\
\text { certificação dos sistemas de } \\
\text { gestão }\end{array}$ & $\begin{array}{l}\text { • As empresas sem um } \\
\text { sistema de gestão em } \\
\text { qualidade, saúde, segurança } \\
\text { e meio ambiente não } \\
\text { sobreviverão }\end{array}$ \\
\hline & Próximos passos & $\begin{array}{l}\text { - Certificação OHSAS } 18000 \text { e } \\
\text { SA } 8000 \text { em } 2004 \\
\text { - Prêmio Nacional da Qualidade } \\
\text { em 2005/2006 }\end{array}$ & $\begin{array}{l}\text { - A busca da Certificação SA } \\
8000 \\
\text { - Prêmio Nacional da Qualidade }\end{array}$ & $\begin{array}{l}\text { - Refinamento do SGI } \\
\text { - Benchmarking externo } \\
\text { - Informações com mais } \\
\text { rapidez }\end{array}$ \\
\hline
\end{tabular}


Quadro 13 - Entrevista com os Gestores de SMS - cont.

\begin{tabular}{|c|c|c|c|c|}
\hline $\begin{array}{l}\text { Ciclo } \\
\text { PDCA }\end{array}$ & Roteiro da Entrevista & Empresa A & Empresa B & Empresa C \\
\hline 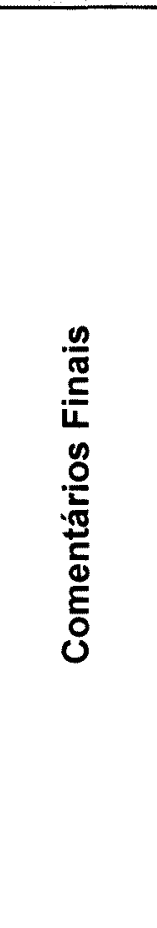 & Gestores de SMS & \begin{tabular}{|l|} 
"Os sistemas de gestão com \\
certeza melhoram o clima \\
interno e a organização do \\
trabalho" \\
"Não existe uma \\
conscientização no Brasil sobre \\
a importância dos sistemas de \\
gestão" \\
- Falta incentivo do Governo e \\
divulgação na mídia \\
- Falta a formação de uma \\
cadeia produtiva que se \\
preocupe com o assunto \\
- Falta incentivo às pequenas \\
empresas para que elas possam \\
se desenvolver e crescer de \\
maneira sustentada
\end{tabular} & $\begin{array}{l}\text { "O sistema integrado de gestão } \\
\text { para nós é uma ferramenta } \\
\text { muito útil" } \\
\end{array}$ & $\begin{array}{l}\text { "A universidade pode ajudar a } \\
\text { exemplo de outras empresas } \\
\text { na polarização desses } \\
\text { assuntos para se chegar lá } \\
\text { com mais velocidade" }\end{array}$ \\
\hline
\end{tabular}




\subsection{Discussões}

Foram avaliados no questionário da pesquisa científica 125 itens e hierarquizados através dos gráficos de Pareto de 1 a 7.

Os itens são classificados em significância alta, média e baixa de acordo com o critério estabelecido no Quadro 14.

Quadro 14 - Nível de Significância

\begin{tabular}{|c|c|c|}
\hline \multicolumn{3}{|c|}{ Significância dos itens avaliados } \\
\hline Alta & Média & Baixa \\
\hline $\mathrm{P} \geq 10$ & $5 \leq \mathrm{P}<10$ & $\mathrm{P}<5$ \\
\hline
\end{tabular}

P é a Porcentagem

O nível de significância serve de auxílio para priorizar os itens de interesse da indústria na busca da eficiência operacional e melhoria contínua dos sistemas de gestão de saúde, meio ambiente e segurança do trabalho.

Foram discutidos somente os itens com nível de significância alta, ou seja, com $\mathrm{P} \geq 10$.

\subsubsection{Principais Fatores Positivos de SMS que afetam a Eficiência Operacional da Indústria Siderúrgica no Brasil}

Do Gráfico 1 pode-se observar que os itens de avaliação 1, 2, 3 e 4 que afetam o comportamento e atitude da força de trabalho tiveram pontuação elevada, enquanto os itens de avaliação $12,13,14$ e 15 que afetam diretamente o custo do produto tiveram pontuação baixa.

Item 1 - A alta direção da indústria tem papel fundamental na motivação da força de trabalho e na transmissão dos valores agregados ao desempenho operacional e serve também para demonstrar coerência entre o discurso e a prática. 
Item 2 - A alta direção exerce o papel de liderança na condução das diretrizes para a mudança da cultura organizacional através da formalização da política de saúde, meio ambiente e segurança do trabalho.

Este aspecto já foi relatado por West e Michand (1995, p. 40) de que a declaração da política corporativa é o mais simples e importante passo. Como Dennis Kinlaw citado por West e Michand, afirma:

A declaração da política estabelece regras e expectativas para a organização através de:

1) Esclarecimentos para a força de trabalho sobre a importância da saúde, meio ambiente e segurança do trabalho para o negócio; 2) Integração dos assuntos de SMS com as estratégias da organização; 3) Foco da indústria naqueles poucos itens de interesse que são cruciais para o seu futuro.

Item 3 - A conscientização e comprometimento da força de trabalho está ligada à motivação, ou seja, à vontade que as pessoas têm em realizar seus trabalhos da melhor maneira possível, porém é necessário preparar as pessoas para que elas bem desempenhem suas funções. Segundo Moura, a conscientização diz respeito a "querer fazer" enquanto o treinamento a "saber fazer".

Item 4 - Os fatores positivos de SMS requerem uma abordagem que ressalta a prevenção. Os sistemas pró-ativo de gerenciamento devem promover a melhoria contínua. Nas indústrias siderúrgicas pesquisadas a decisão para o planejamento e implementação de sistemas de gestão teve como percepção:

\footnotetext{
$\checkmark$ Incentivos do Governo (indústria A).

$\checkmark$ Liderança de mercado (indústria B e C).

$\checkmark$ Competitividade (indústria $\mathrm{B}$ e $\mathrm{C}$ ).

$\checkmark$ Proteção ao trabalhador (indústria $\mathrm{C}$ ).
} 
As ações preventivas estão contempladas nos padrões normativos dos sistemas de gestão ISO 14001 e OHSAS 18001, porém a metodologia da avaliação dos aspectos e impactos ambientais, riscos e perigos de saúde e segurança do trabalho ficam a critério da organização.

\subsubsection{Como os Fatores Positivos de SMS afetam a Eficiência Operacional}

Observando o Quadro 11 pode-se ver que os sistemas de gestão SMS dependem de exigências internas (padrão normativo, requisitos contratuais e estatutários, políticas e diretrizes), externas (requisitos legais e regulamentares, princípios e códigos, órgãos de fiscalização e controle, clientes e tendências de mercado) e de fatores que possam buscar a eficiência operacional e melhoria do desempenho. Friedman resume os fatores positivos de SMS como "a atitude do alto executivo..."

Friedman resume a atitude do alto executivo em estabelecer diretrizes estratégicas para proteção da saúde, segurança, meio ambiente, propriedade e seus impactos na preservação e elevação dos valores dos stakeholders. Fica evidente pelos itens a seguir apresentados, que:

Item 1 - A alta direção através do alinhamento das estratégias de salvaguardar a vida e a propriedade tem a responsabilidade de promover a melhoria contínua com resultados mensuráveis.

Item 2 - As maiores barreiras para a melhoria do desempenho não são técnicas e sim comportamental.

Item 3 - A proteção da saúde humana, da segurança do trabalho, do meio ambiente é uma das mais altas prioridades do negócio.

Item 4 - A conformidade deve ser um caminho natural de desenvolver o trabalho. As ações preventivas impulsionam os sistemas de gestão SMS e promovem a melhoria do desempenho operacional. 


\subsubsection{Principais Fatores Negativos de SMS}

Do Gráfico 2 observa-se que os fatores negativos de SMS requerem uma abordagem sob dois aspectos: mudanças internas e externas.

Mudar implica entender que (Kisil, p. 3):

- Mudar é um processo que envolve pessoas, organizações e sistemas sociais.

- Mudar requer que se conheça a razão de mudar e as forças de trabalho desestabilizadoras do atual status quo.

- Mudar exige conhecer o que se quer mudar.

- Mudar significa que se conheça de onde se está partindo e aonde se quer chegar.

- Mudar exige organizar e gerenciar o processo de mudanças.

- Mudar exige de quem tem autoridade, a decisão de mudar.

As necessidades de saúde, meio ambiente e segurança do trabalho são estabelecidas diretamente pelas empresas e partes interessadas, quanto indiretamente, por decisões políticas tomadas por meio de acordos regionais ou mesmo internacionais e, ainda, pelo estabelecimento de novas legislações. Tais necessidades estão baseadas, por um lado, no atual estágio do conhecimento científico e, por outro, nas percepções dos assuntos de SMS.

Com esse enfoque as mudanças internas são exigidas para que as indústrias siderúrgicas mantenham a competitividade com base nos princípios de desenvolvimento sustentável, responsabilidade social e proteção à vida, e, portanto, o reconhecimento de SMS, como uma das prioridades da empresa, requer métodos estruturados, sistematizados e a identificação de variáveis para análise estratégica de mudanças na indústria.

As mudanças externas ocorrem através dos padrões normativos exigidos pelo mercado. Como as indústrias siderúrgicas operam globalizadas, podemos afirmar que é um segmento de vanguarda na busca do aprimoramento tecnológico e da eficiência operacional a nível mundial. 
O representante da empresa B não atribuiu pontos para os Fatores Negativos, portanto a média foi calculada com as pontuações das empresas A e C. Ele afirma que inicialmente na empresa existia por parte de alguns colaboradores o receio de que a implantação/certificação de SMS acarretasse mais custos sem retorno.

Dos itens a seguir pode-se evidenciar que:

Item 1 - A falta de reconhecimento de SMS como uma das prioridades da indústria siderúrgica pode levar a sérios perigos para o homem e o meio ambiente, imediatos ou a longo prazo, internamente externamente.

Item 2 - A divulgação pública de desempenho de SMS permite a comparação entre as indústrias e estimula as boas práticas de gestão. Nesse sentido, a regulamentação contribuirá para o aprimoramento dos mecanismos de controle e fiscalização.

Item 3 - Esforços para criar e manter um ambiente de trabalho e um clima organizacional que conduzam à melhoria da eficiência operacional, à plena participação e ao crescimento pessoal e da indústria devem estar em consonância com as estratégias organizacionais.

Item 4 - O uso da certificação como instrumento de marketing pode não expressar a credibilidade e confiança pública em relação aos resultados atingidos pela indústria.

Item 5 - As indústrias pesquisadas estão exigindo que os fornecedores atendam os requisitos de SMS e em alguns casos os fornecedores assinam um termo de compromisso para a certificação, ou seja, o poder de compra do cliente exerce influência na cadeia produtiva.

Item 6 - A formação da equipe de SMS multidisciplinar, com atuação integrada e com a orientação de contribuir na construção da sustentabilidade é um obstáculo a ser vencido pelas indústrias. 


\subsubsection{Como os Fatores Negativos de SMS afetam a Eficiência Operacional}

Do Quadro 12 observa-se que é importante a aceitação das atividades da indústria pela sociedade, portanto, a construção da imagem pública a fim de torná-la mais atraente para o mercado leva em consideração o desempenho de SMS.

Os itens do Quadro 12 identificam que:

Item 1 - Além do prejuízo da imagem pública pelo não atendimento das ações de SMS, a indústria pode provocar danos materiais e pessoais com custos elevados.

Item 2 - O desempenho de SMS é um fator de competitividade e pode contribuir com a expansão de mercado, com isso a indústria que divulga voluntariamente os seus resultados demonstra efetivamente a sua responsabilidade social.

Item 3 - Alinhamento da força de trabalho com as políticas e diretrizes da indústria.

Item 4 - A divulgação errônea da certificação pode afetar a imagem pública da indústria.

Item 5 - Alinhamento da cadeia produtiva (fornecedores) com as exigências de mercado.

Item 6 - A concepção dos sistemas de gestão SMS é responsável pela eliminação do desperdício, uso racional dos recursos, diminuição de resíduos, acidentes e outros benefícios compensadores. 


\subsubsection{Benefícios da Implantação SMS}

Do Gráfico 3 observa-se que a relação entre os princípios adotados pelas diversas instituições ligadas aos respectivos segmentos empresariais expressa, potencialmente, condições para a vantagem competitiva, traduzida em níveis mais elevados de inserção e comprometimento das empresas com as questões de saúde, meio ambiente e segurança do trabalho.

Almeida e Col afirmam: A saída que o desenvolvimento sustentável representa, em especial para a indústria, motivou a manifestação de diversas instituições de âmbito internacional, na proclamação de princípios e estabelecimentos de códigos de lideranças setoriais para uma postura de responsabilidade social.

A carta empresarial para o desenvolvimento sustentável da Câmara de Comércio Internacional contempla dezesseis (16) princípios, entre eles:

\section{a) Cumprimento de Regulamentos e Informação (Princípio 16)}

Aferir o desempenho das ações sobre o meio ambiente, proceder regularmente a auditorias ambientais e avaliar o cumprimento das exigências internas da empresa, dos requisitos legais e dos demais princípios; e, periodicamente, fornecer as informações pertinentes ao conselho de administração, aos acionistas, ao pessoal, às autoridades e ao público.

Dos itens do Gráfico 3 pode-se observar que:

Item 1 - Na implantação de sistemas de gestão de SMS a indústria deve planejar, avaliar e controlar os aspectos, impactos, riscos e perigos de suas atividades, produtos ou serviços, bem como identificar e ter acesso à legislação e outros requisitos aplicáveis.

Item 2 - O envolvimento do pessoal operacional traz melhoria dos processos produtivos, redução dos acidentes, incidentes e vazamentos, aumenta o reaproveitamento, reciclagem e recuperação de materiais. 
Item 3 - A integração de políticas, programas e procedimentos evita conflitos entre as áreas e aprimora a tomada de decisões estratégicas da empresa.

Item 4 - A posição da indústria para o mercado, expressa através da política, consiste na estrutura estratégica formada por compromissos, diretrizes e sistemas de gestão.

Item 5 - Os sistemas de gestão de SMS estabelecem a avaliação inicial, nãoconformidades, auditorias e análise crítica que registram o histórico dos problemas e o encaminhamento das ações corretivas ou ações preventivas.

Item 6 - É atribuída para o nível gerencial responsabilidades e autoridade. O gerente tem as suas competências exigidas pelo próprio sistema e dispõe dos recursos necessários para a efetiva implantação de SMS.

Item 7 - A análise crítica pela alta direção fecha o ciclo PDCA. Os gestores de SMS e o representante da direção elaboram um relatório de desempenho utilizando-se de diversas fontes de informações e apresentam os resultados para análise, próximos passos, aprovação de recursos, diretrizes e melhoria contínua.

Item 8 - As práticas da empresa quando exigido pelo padrão normativo são documentadas de forma organizada e permite a informação certa na hora certa. Os documentos dos sistemas de gestão de SMS são atualizados e constituem-se em uma excelente ferramenta de padronização das atividades e treinamento.

\subsubsection{Principais Benefícios da Manutenção de SMS}

Do Gráfico 4 procurou-se responder:

Quem se beneficia com a manutenção de SMS? 
- A indústria: com a melhoria da eficiência operacional, redução de custos e combate às formas de desperdícios.

- O meio ambiente: na medida em que as indústrias adotam tecnologia limpa reduzem a poluição e melhoram os indicadores de eco-eficiência.

- O trabalhador: pois tem direito a uma vida saudável e produtiva.

- Os acionistas: pois tomam conhecimento do desempenho de SMS e das atividades da empresa que seguem princípios de atuação responsável e desenvolvimento sustentável.

- As partes interessadas: com a melhoria das relações e transparência de informações e resultados.

Os itens do Gráfico 4 identificam que:

Item 1 - A busca pela eficiência operacional requer uma visão de futuro e a intenção de continuidade das atividades da indústria. Os sistemas de gestão de SMS contribuem para um relacionamento transparente e sadio assim como reforça a habilidade em criar valor e contribuir para um crescimento econômico sustentável.

Item 2 - A manutenção de SMS auxilia a empresa a alcançar seus objetivos e metas através dos Programas de Gestão que é o desdobramento das metas em um plano de ação detalhado, no qual estejam definidos os meios (recursos) para se atingirem as metas, os responsáveis pelas ações e os prazos.

Item 3 - Os programas de gestão de saúde, meio ambiente e segurança do trabalho englobam ações de melhoria, economia de energia nos processos, campanhas educativas de saúde e fatores que afetam a eficiência operacional da indústria. 
Item 4 - Os procedimentos documentados e a padronização das atividades criam um espírito de confiança e autodisciplina da força de trabalho em direção aos objetivos e metas da organização.

Item 5 - Os sistemas de gestão de SMS são os alicerces para a construção da atuação responsável e desenvolvimento sustentável da indústria, com isso extrapolam a conformidade legal e se colocam em nível de excelência.

Item 6 - É importante que a alta direção tenha comprometimento com a melhoria contínua da gestão de SMS que podem variar de melhorias em pequenos passos até projetos estratégicos de mudança da cultura organizacional.

\subsubsection{Principais Dificuldades da Implantação de SMS}

“A globalização trouxe importantes conseqüências econômicas no mundo inteiro. $O$ processo de mudanças que chega, por enquanto de fora para dentro, afeta a adequação de produtos e a opinião pública. Algumas mudanças já são visíveis no comportamento empresarial, mas a maioria das empresas brasileiras ainda restringe a sua responsabilidade ao atendimento à legislação de SMS" (Almeida e Col, p. 10).

A implantação de SMS requer uma visão estratégica e envolvimento da empresa como um todo. Como os padrões normativos são relativamente recentes, ISO 14001:1996 e a OHSAS 18001:1999, surgem dúvidas e discussões na interpretação e níveis de exigência. Além disso, os conceitos de aspectos, impactos, riscos e perigos são de difícil assimilação e o levantamento a ser feito é amplo e constitui uma tarefa trabalhosa e extensa.

O foco da implantação de SMS vai além da atividade e é direcionado para o mercado globalizado, muitas vezes intangível para a percepção da força de trabalho.

O representante da empresa B não atribuiu pontos para as principais dificuldades da implantação de SMS, portanto, a média foi calculada com as pontuações das empresas $\mathrm{A}$ e C.

Os itens apresentados no Gráfico 5 demonstram que: 
Item 1 - Os sistemas de gestão de SMS requerem conhecimentos que fogem do domínio da maioria das empresas: direito ambiental, normas técnicas de SMS, tecnologia ambiental, análise de riscos e etc.

A Peercenter (2002, p. 2) recomenda um prazo de vinte e quatro meses para a implantação de SMS, porém a velocidade das mudanças, avanços tecnológicos, informações, padrões mais exigentes e fusões de empresas impulsionam o desenvolvimento de projetos com prazos de curta duração, no caso da implantação de SMS de oito a doze meses.

Item 2 - Os custos da etapa de implantação compreendem a elaboração dos documentos normativos, treinamentos dos colaboradores, exames laboratoriais e clínicos, adequação de infra-estrutura e ambiente do trabalho (aspectos ergonômicos), medição e monitoramento, levantamento de dados e auditorias. Porém, dependendo da defasagem entre o desempenho de SMS da planta industrial e os requisitos legais, pode representar investimentos de maior porte.

Item 3 - Em função do porte e da complexidade da indústria siderúrgica há necessidade de vários tipos de documentos que estabelecem e especificam procedimentos e controles operacionais. Portanto, a documentação de SMS, na extensão necessária, simples e de fácil entendimento, contribuirá com a implantação de SMS.

Item 4 - A falta de experiência da equipe de SMS não permitirá o apoio amplo ao negócio e suporte para acompanhar a missão da organização.

Item 5 - Como os projetos de implantação de SMS têm prazos de curta duração, os gestores elaboram os documentos normativos sem a participação dos representantes dos processos que possuem profundo conhecimento e sensibilidade. 
Item 6 - Na indústria os fatores e os métodos para se lidar com a resistência a mudanças são estruturados, sistematizados e as variáveis são identificadas para a realização das análises estratégicas.

\subsubsection{Principais Dificuldades da Manutenção de SMS}

A manutenção de SMS deve ser responsabilidade de um profissional sênior da empresa, ao qual deverá ser delegada autoridade como representante da alta direção. Este profissional deve formar e liderar a equipe de SMS, coletar, organizar e disseminar informações; delegar tarefas e estabelecer prazos; cobrar e avaliar o trabalho; facilitar a visibilidade e envolvimento da alta direção e obter suporte de funções multidisciplinares.

As competências exigidas para a função:

- Conhecimento completo das operações.

- Excelência em gerenciamento de projetos.

- Bom comunicador (em todos os níveis da organização).

- Eficaz, entusiasta e tutor.

- Confiança da força de trabalho.

- Personalidade agradável.

- Insensível.

O representante da direção deve conduzir a manutenção de SMS com autoridade ou flexibilidade, conforme o caso, não ter medo de falhar e estar pronto para recomeçar com entusiasmo.

As dificuldades da manutenção de SMS são administradas levando-se em consideração:

- O apoio da alta direção.

- A autoridade compatível com a responsabilidade.

- Treinamento da equipe de SMS.

- O grau de maturidade dos sistemas de gestão SMS (tempo).

- A alocação de recursos humanos, físicos e financeiros.

- A comunicação das ações de gestão de SMS. 
- A mudança da cultura organizacional.

A análise crítica pela alta direção é o elemento final do ciclo dos sistemas de gestão de saúde, meio ambiente e segurança do trabalho. É uma oportunidade para fazer correções e ajustes na manutenção de SMS. A alta direção determina se a manutenção de SMS está funcionando ou não, onde os recursos são necessários, se a política está adequada ou é necessário mudanças. É responsabilidade do representante da alta direção formecer informações suficientes para o Gerente Sênior poder avaliar a efetividade da manutenção de SMS.

Os itens apresentados no Gráfico 6 identificam a necessidade de:

Item 1 - Divulgação pela alta direção dos objetivos e metas a serem alcançados, desempenho de SMS do ano anterior, da missão e visão de desenvolvimento sustentável.

Item 2 - É imprescindível que haja um apoio forte da alta direção e que a equipe de SMS esteja ligada ao mais alto nível da organização.

Item 3 - A indústria dispõe de vários meios de comunicação, porém é necessário certificar-se de que as informações estão produzindo o efeito desejado.

Item 4 - A política de SMS é formulada após o conhecimento da situação atual da indústria, das operações que afetam a saúde, meio ambiente e segurança do trabalho e as atuais práticas de gestão de SMS.

Item 5 - Para melhorar o alinhamento da equipe operacional é necessário fazer um aporte de conhecimento através dos programas de conscientização e treinamento.

Item 6 - A divulgação das diretrizes e a comunicação clara das responsabilidades e autoridade auxiliam na melhoria do desempenho operacional e envolve diretamente as pessoas para atingir os objetivos e metas de SMS. 


\subsubsection{Principais Indicadores de SMS que Medem a Eficiência Operacional da Indústria Siderúrgica no Brasil}

Muitas organizações estão buscando caminhos para entender, demonstrar e melhorar o seu desempenho em saúde, meio ambiente e segurança do trabalho.

A indústria com sistema de gestão de SMS deve avaliar o seu desempenho de SMS e identificar áreas para melhorar conforme o necessário.

Outras ferramentas de gestão podem usar as informações adicionais que incluem análise crítica de SMS e avaliação de ciclo de vida.

Foram selecionados para a pesquisa de campo, sessenta e um indicadores quantitativos ou qualitativos para melhor entendimento da eficiência operacional. $O$ resultado apresentado no Gráfico 7 demonstra que:

Desse total, trinta e dois indicadores obtiveram porcentagem maior ou igual a $10 \%$, ou seja, de significância alta.

$O$ representante da empresa $C$ não atribuiu pontos para o indicador financeiro Gráfico 7.4, portanto, a média foi calculada com as pontuações das empresas A e B.

\subsubsection{Entrevista com os Gestores de SMS}

A entrevista com os gestores de SMS que originou o Quadro 13 enriqueceu a pesquisa e demonstrou ser uma excelente ferramenta para melhor entendimento das questões apresentadas no questionário.

As indústrias siderúrgicas pesquisadas $\mathrm{A}, \mathrm{B}$ e $\mathrm{C}$ apresentam um estágio de desenvolvimento dos sistemas de gestão de SMS as quais demonstram níveis equivalentes e tendências rumo a excelência, desenvolvimento sustentável e responsabilidade social.

Podemos afirmar com base nas informações coletadas que os sistemas integrados de gestão é o melhor caminho para as outras indústrias que estão em fase de implantação de SMS.

As indústrias com liderança de mercado e aquelas com certificações de qualidade, meio ambiente, segurança e saúde ocupacional e responsabilidade social 
têm compromisso com o desenvolvimento dos fornecedores de produtos e de serviços.

O benchmarking ainda é uma ferramenta a ser introduzida e aprimorada nos sistemas de gestão das empresas pesquisadas A e C.

Os sistemas de gestão em níveis avançados (empresa B) atuam nas ações de prevenção e não são observados desvios normativos, ou seja, são consideradas empresas de excelência.

O código de ética das empresas $\mathrm{B}$ e C está com enfoque para a força de trabalho e não engloba acionistas, fornecedores, clientes e órgãos públicos.

A consultoria jurídica é essencial no gerenciamento das mudanças externas e nas ações de controle.

O balanço social da indústria é uma realidade hoje. A empresa B é um exemplo a ser seguido.

É preciso que haja uma integração da indústria e da universidade para o desenvolvimento de projetos na busca da eficiência operacional e na difusão das melhores práticas de gestão de SMS. 


\section{Quadro 15 - Principais Indicadores de SMS da Indústria Siderúrgica}

\begin{tabular}{|c|c|c|}
\hline Item & Indicadores de Eco-Eficiência & Unidade \\
\hline & Indicador de Material & \\
\hline 1 & Quantidade de material reciclado no processo & ton./ano \\
\hline 2 & Quantidade de efluentes enviados para o corpo d'água & $\mathrm{m}^{3} / \mathrm{ano}$ \\
\hline 3 & Quantidade de sucata metálica gerada no processo & ton./ano \\
\hline 4 & Quantidade de residuo classe I (perigoso) gerado no processo & ton./ano \\
\hline 5 & Quantidade de aço laminado produzida & ton./ano \\
\hline \multirow[t]{2}{*}{6} & Quantidade de emissão de gases para a atmosfera & ton./ano \\
\hline & Indicador de Capital Humano & \\
\hline 7 & Número de hora-homem de treinamento & $\mathrm{HH} / \mathrm{ano}$ \\
\hline 8 & Número de sugestőes de SMS proposta por col & $n^{\circ}$ sugestōes / col \\
\hline 9 & Investimento em capacitação profissional & US\$ / col \\
\hline 10 & Colaboradores com qualificação ou certificação profissional (\%) & $\frac{n^{0} \mathrm{col}}{\text { total }} \times 100$ \\
\hline \multirow{3}{*}{11} & \multirow{2}{*}{ Grau de escolaridade dos colaboradores (\%) } & até $2^{\circ}$ grau \\
\hline & & superior \\
\hline & Indicador de Energia & \\
\hline 12 & Quantidade de energia elétrica consumida & Kwh / ano \\
\hline 13 & Quantidade de gás (natural, GLP, oxigênio, etc.) & $\mathrm{m}^{3} /$ ano \\
\hline \multirow[t]{2}{*}{14} & Quantidade de combustivel (óleo, gasolina, etc.) & litros / ano \\
\hline & Indicador Financeiro & 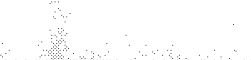 \\
\hline 15 & Investimento em pesquisa para reduçăo do consumo de RN & US\$ / ano \\
\hline 16 & Alocação de recursos para substituição de gás CFC & US\$ / ano \\
\hline 17 & Investimentos em ações preventivas de SMS & US\$ / ano \\
\hline 18 & Custo do desperdício de RN utilizados no processo & US\$ / ano \\
\hline 19 & Recursos aplicados nos sistemas de gestāo de SMS & US\$ / ano \\
\hline 20 & Retorno dos investimentos em projetos de melhoria & US\$ / ano \\
\hline 21 & Custo do desperdício de energia elétrica & US\$ / ano \\
\hline
\end{tabular}


Quadro 15 - Principais Indicadores de SMS da Indústria Siderúrgica - cont.

\begin{tabular}{|c|l|c|}
\hline Item & \multicolumn{1}{|c|}{ Indicadores de Eco-Eficiência } & Unidade \\
\hline 22 & \multicolumn{1}{|c|}{ Indicador das Condiçóes Ambientais } & \\
\hline 23 & Manuipamentos com tecnologia de controle ambiental & $\mathrm{N}^{\circ}$ total / planta \\
\hline 24 & Aspectos e impactos ambientais significativos & $\mathrm{HH} /$ ano \\
\hline 25 & Paralisações para atendimento das condições ambientais & $\mathrm{N}^{\circ}$ total/planta \\
\hline 26 & Valor máximo do nivel de ruido da planta & $\mathrm{HH} / \mathrm{ano}$ \\
\hline 27 & Valor máximo da temperatura no ambiente de trabalho & $\mathrm{dB}(\mathrm{A})$ \\
\hline & \multicolumn{1}{|c|}{ Indicador de Gestăo de SMS } & ${ }^{\circ} \mathrm{C}$ \\
\hline 28 & Redução de EE consumida por ton. de aço produzida & $\mathrm{Kwh} /$ ton. \\
\hline 29 & $\begin{array}{l}\text { Investimentos em ações de gestão com melhoria no desempenho } \\
\text { operacional }\end{array}$ & $\mathrm{US \$} /$ ano \\
\hline 30 & Ações corretivas e preventivas implementadas por ano & $\mathrm{N}^{\circ}$ total / planta \\
\hline 31 & Simulados de PAE realizados por ano & $\mathrm{N}^{\circ}$ total / planta \\
\hline 32 & Redução do consumo de produtos quimicos nocivos à saúde & $\mathrm{Kg} /$ ano \\
\hline
\end{tabular}

Legenda:

CFC - Clorofluorcarbono

SMS - Saúde, meio ambiente e segurança do trabalho

$\mathrm{dB}(\mathrm{A})$ - Nivel de potência sonora, medido em decibel

${ }^{\circ} \mathrm{C}$ - Grau Celsius

US\$ - Moeda Americana

PAE - Plano de atendimento a emergências

$\mathrm{COL}$ - Colaborador

RN - Recursos Naturais

EE - Energia Elétrica 


\section{CONSIDERAÇÕES FINAIS}

- A pesquisa exploratória realizada permitiu analisar o problema proposto inicialmente pelo pesquisador na profundidade e abrangência necessária.

- O questionário da pesquisa e o roteiro da entrevista foram ferramentas utilizadas para o trabalho de campo que se completaram e se revelaram apropriadas para atingir o objetivo geral e os objetivos específicos da pesquisa científica.

- A pesquisa bibliográfica permitiu aprofundar o conhecimento sobre os sistemas de gestão de saúde, meio ambiente e segurança do trabalho.

- Os sistemas integrados de gestão são adotados pelas três indústrias siderúrgicas pesquisadas e teve seu início com o sistema de gestão da qualidade seguido pelos sistemas de gestão da saúde, meio ambiente e segurança do trabalho e com tendências de mercado para o sistema de gestão de responsabilidade social e Prêmio Nacional da Qualidade. Os modelos de gestão do Prêmio Nacional da Qualidade e Eco-Management and Audit Scheme são os mais abrangentes, ou seja, com maior número de elementos e denominados padrões de excelência enquanto os demais modelos apresentados são considerados métodos de padronização.

- O comportamento e a atitude das pessoas estão associados aos principais fatores positivos que afetam a eficiência operacional da indústria siderúrgica.

- A atitude da alta direção define o rumo à melhoria da eficiência operacional.

- As estratégias organizacionais auxiliam no combate dos principais fatores negativos que afetam a eficiência operacional da indústria siderúrgica.

- O desempenho de saúde, meio ambiente e segurança do trabalho indica o efeito dos principais fatores negativos que afetam a eficiência operacional da indústria siderúrgica. 
- A alta direção assume formalmente perante os stakeholders o seu compromisso com as questões de saúde, meio ambiente e segurança do trabalho.

- Os sistemas de gestão de saúde, meio ambiente e segurança do trabalho influenciam os valores, as estratégias e os planos da empresa e também contribuem para a responsabilidade social e o desenvolvimento sustentável.

- É necessário internalizar o conhecimento exigido pelas mudanças externas com agilidade e rapidez. Para isso, é requerido elevado nível de preparação da força de trabalho.

- Os indicadores de eco-eficiência operacional da indústria são ferramentas a serem implementadas em direção à melhoria contínua.

- A indústria siderúrgica brasileira está inserida no mercado globalizado rumo à excelência na busca da responsabilidade social e dos princípios do desenvolvimento sustentável. 


\section{RECOMENDAÇÕES}

As recomendações apresentadas estão baseadas em lições aprendidas, tanto da revisão bibliográfica como da pesquisa, onde procurou-se identificar os benefícios, dificuldades e chaves para o sucesso na implantação e na manutenção de sistemas de gestão de saúde, meio ambiente e segurança do trabalho (SMS) com enfoque e aplicação na indústria siderúrgica.

\subsection{Principais Fatores Positivos de SMS que Afetam a Eficiência Operacional da Indústria Siderúrgica no Brasil}

7.1.1 Para o envolvimento do executivo: Convém utilizar a ferramenta $5 \mathrm{~W} 2 \mathrm{H}$ para a implementação de um plano de ação dos itens da pesquisa de significância alta e decisões da alta direção (ver Quadro 16), ou seja:

- Definir o que será feito (What).

- Definir quando será feito (When).

- Definir quem fará (Who).

- Definir onde será feito (Where).

- Definir por que será feito $(W h y)$.

- Definir como será feito (How).

- Definir quanto custará (How Much).

Sugere-se como Meta: Atingir o índice de $80 \%$ da força de trabalho, conscientizados e comprometidos com a eco-eficiência.

e deve-se utilizar como Indicador: Lista de verificação com perguntas fechadas aplicada nas auditorias internas de SMS. 
Quadro 16 - 5W2H

\begin{tabular}{|c|c|c|c|c|c|c|}
\hline \multicolumn{7}{|c|}{ Plano de Ação 5W2H } \\
\hline O Quê? & Quando? & Quem? & Onde? & Por quê? & Como? & $\begin{array}{l}\text { Quanto } \\
\text { custará? }\end{array}$ \\
\hline $\begin{array}{l}\text { Envolvimento } \\
\text { da alta direção }\end{array}$ & $\begin{array}{l}1^{\circ} \text { dia útil } \\
\text { de cada } \\
\text { mês }\end{array}$ & $\begin{array}{l}\text { Diretores } \\
\text { Gerentes } \\
\text { Gestores } \\
\text { de SMS }\end{array}$ & $\begin{array}{l}\text { Sala de } \\
\text { Reunião da } \\
\text { Diretoria } \\
\\
\\
\end{array}$ & $\begin{array}{l}\text { Definir } \\
\text { estratégia } \\
\text { para } \\
\text { conscienti- } \\
\text { zação e } \\
\text { comprome- } \\
\text { timento da } \\
\text { força de } \\
\text { trabalho }\end{array}$ & $\begin{array}{l}\text { - Apresentação } \\
\text { de diagnóstico } \\
\text { - Análise crítica } \\
\text { - Diretrizes e } \\
\text { ações para a } \\
\text { gestão de } \\
\text { pessoas }\end{array}$ & $\begin{array}{l}\text { Orçamento a } \\
\text { ser } \\
\text { apresentado } \\
\text { para a } \\
\text { aprovação da } \\
\text { diretoria }\end{array}$ \\
\hline
\end{tabular}

7.1.2 Implementar o processo de mudança da cultura organizacional da indústria siderúrgica em três (3) fases:

a) Análise da situação atual da indústria.

Verificar "onde estamos" no momento; no tocante ao desempenho operacional da indústria quanto aos seus produtos, serviços prestados e sistemas de produção.

$\checkmark$ Despertar a consciência e comprometimento da força de trabalho para a eco-eficiência.

$\checkmark$ Mostrar o papel de cada um na melhoria do desempenho operacional.

$\checkmark$ Identificar as oportunidades de melhoria.

b) Estabelecimento de metas

Estudar as possibilidades físicas de materiais, de recursos disponíveis e interesses da indústria expressos pela sua política para definir "aonde queremos chegar". 
c) Estabelecimento de métodos

Definir "como chegar". A palavra método tem sua origem grega que significa "caminho para se alcançar a meta".

7.1.3 Convém explicar que a conscientização e comprometimento da força de trabalho é uma parte vital para o planejamento pró-ativo de SMS e para o gerenciamento das mudanças que podem afetar o desempenho operacional e incluem:

a) Mudanças internas

1. Modificação de processos.

2. Modificação de software.

3. Rotatividade da força de trabalho.

4. Alterações nos procedimentos e instruções de trabalho.

5. Propostas de novos produtos, novas fábricas ou novos processos ou serviços.

b) Mudanças externas

1. Nova legislação.

2. Gestão do conhecimento e tecnologia.

7.1.3.1 Implementar treinamento formal para assegurar que a força de trabalho esteja consciente de:

- A importância de estar em conformidade com a política e os procedimentos de SMS.

- Suas funções e responsabilidades.

- Aspectos, impactos ambientais, riscos e perigos resultados das atividades industriais, reais e potenciais.

- Penalidades e riscos com as conseqüências do não cumprimento dos procedimentos especificados.

- Os benefícios resultantes para a empresa e a sua força de trabalho quando ocorrer um bom desempenho operacional. 
7.1.4 Convém introduzir nos sistemas de gestão de saúde, meio ambiente e segurança do trabalho métodos de análise de risco quantitativos e qualitativos, alguns simples e outros complexos, tais como: o método "E se?" (se acontecer isto, quais serão as conseqüências?), os cinco por quês, a análise preliminar de perigos (APP), a árvore de falhas, etc..

\subsection{Considerando Como os Fatores Positivos de SMS Afetam a Eficiência Operacional (Quadro 11), recomenda-se:}

7.2.1 Implementar na indústria siderúrgica os indicadores de eco-eficiência.

7.2.2 Aplicar o fundamento da excelência denominado "valorização das pessoas" desenvolvido pela Fundação para o Prêmio Nacional da Qualidade - FPNQ.

7.2.3 Classificar os objetivos e metas em curto ( 6 meses a 1 ano), médio ( $>1$ ano a 2 anos) e longo (acima de 2 anos) prazo.

7.2.4 Implementar um programa de avaliação das rotinas diárias. A avaliação pode ajudar a identificar áreas onde o custo da conformidade pode ser reduzido ou evitar a ocorrência de acidentes e desenvolver a conscientização em todos os níveis da organização.

\subsection{No Sentido de Minimizar os Fatores Negativos de SMS Evidenciados no Gráfico 2, recomenda-se:}

7.3.1 Divulgar a resolução $\mathrm{n}^{\circ} 174$ e as recomendações complementares $\mathrm{n}^{\circ} 181 \mathrm{da}$ Organização Internacional do Trabalho (OIT) sobre a prevenção de acidentes industriais ampliados.

7.3.2 Publicar desempenho de SMS através do balanço social em jornais e meios de comunicação. 
7.3.3 Introduzir indicadores para avaliação do clima organizacional levando em consideração o bem estar, a satisfação e a motivação da força de trabalho.

7.3.4 Declarar publicamente os objetivos e metas de SMS para a melhoria da eficiência operacional.

7.3.5 Desenvolver programas de qualificação de fornecedores e auditorias de monitoramento.

7.3.6 Capacitar os profissionais da saúde, meio ambiente e segurança do trabalho para dar suporte amplo ao negócio.

\subsection{Considerando que há Fatores Negativos de SMS que Afetam a Eficiência Operacional (Quadro 12) e no Sentido de Minimizá-los, recomenda-se:}

7.4.1 Implementação da gestão de controle de perdas da Det Norske Veritas (DNV).

7.4.2 Criar uma lei que exija a divulgação do balanço social para indústrias de elevado grau de risco.

7.4.3 Aprimorar o processo de comunicação interna da organização.

7.4.4 Divulgar a certificação com base em normas e regulamentos do processo de acreditação reconhecidos pelo INMETRO ou órgãos internacionais.

7.4.5 Aplicar nos fornecedores o padrão normativo da indústria.

7.4.6 Treinar e formar equipes multidisciplinares de SMS. 


\subsection{Do apresentado no Gráfico 3, os Principais Benefícios da Implantação de SMS, recomenda-se:}

7.5.1 Contratar empresa especializada para auxiliar a indústria na aplicação da legislação de SMS a nível federal, estadual e municipal.

7.5.2 Implantar programa de motivação.

7.5.3 Divulgar a integração de políticas, programas e procedimentos a todos os níveis da organização.

7.5.4 Divulgar publicamente a política, programas de gestão, objetivos e metas de SMS.

7.5.5 Disseminar os conceitos de não-conformidade, ação corretiva e ação preventiva a todos os níveis da organização.

7.5.6 Nomear como representante da alta direção um profissional sênior de nível gerencial, através de carta assinada pelo principal executivo da indústria.

7.5.7 Incluir no relatório de desempenho informações comparativas dos indicadores de SMS.

7.5.8 Formalizar através de procedimentos documentados as principais práticas e rotinas desenvolvidas pela empresa.

7.6 Sendo importante a Manutenção de SMS (Gráfico 4) e para obter os Benefícios Diretos, recomenda-se:

7.6.1 Implementar o check list ABCD para excelência operacional da Oliver Wight International. 
7.6.2 Estabelecer objetivos e metas de SMS corporativo, gerencial e setorial.

7.6.3 Estabelecer programas de gestão para cada um dos Fatores positivos de SMS que afetam a eficiência operacional.

7.6.4 Criar um ambiente de confiança e pró-atividade.

7.6.5 Apoiar a indústria na participação do Prêmio Nacional da Qualidade.

7.6.6 Implementar um processo para identificar e gerenciar atividades de melhoria.

\subsection{No Sentido de Reduzir as Dificuldades da Implantação de SMS (Gráfico 5), recomenda-se:}

7.7.1 Contratar serviços de empresas de consultoria ou especialistas para auxiliar na implantação, treinamento e auditorias de SMS.

7.7.2 Elaborar uma planilha de custo detalhada para o atendimento de cada requisito normativo e abrir uma conta contábil para apropriação e controle.

7.7.3 Integrar os documentos normativos de SMS.

7.7.4 Contratar pesquisadores de centros de excelência para a formação da equipe de SMS de alto desempenho na indústria siderúrgica.

7.7.5 Elaborar os documentos normativos de forma participativa.

7.7.6 Escolher um ou mais métodos proposto por Kotter e Schlesinger citado por Kisil (1998; p. 3) para lidar com a resistência a mudanças.
a) Educação + Comunicação.
b) Participação + Envolvimento.
c) Facilidade + Apoio 
d) Negociação + Acordo

e) Manipulação + cooptação

f) Coação explícita + Coação implícita.

\subsection{No Sentido de Reduzir as Dificuldades da Manutenção de SMS (Gráfico 6), recomenda-se:}

7.8.1 Criar informativa escrita e periódica com mensagens de SMS da alta direção para a força de trabalho.

7.8.2 Criar uma gerência ou diretoria de SMS.

7.8.3 Conhecer e utilizar o feedback como ferramenta para influenciar as ações futuras e aumentar a efetividade da comunicação. Feedback é um termo relacionado com a interdependência de ação e reação.

7.8.4 Criar um plano de ação para atendimento da política de SMS com base em informações e dados de desempenho da indústria.

7.8.5 Internalizar na indústria siderúrgica as preocupações dominantes na sociedade e colaborar com a conservação do meio ambiente.

7.8.6 Encorajar ativamente a realimentação e a comunicação pelas pessoas na organização como meio de promover seu envolvimento.

7.9 Como resultado dos principais indicadores de SMS que medem a eficiência operacional da indústria siderúrgica no Brasil (Quadro 15) recomenda-se:

7.9.1 O modelo da Tabela 4 pode ser utilizado pela indústria siderúrgica para um processo de gestão interna que usa indicadores de eco-eficiência e fornecem 
informações comparativas do desempenho operacional do passado e presente da indústria.

Tabela 4 - Gestão Interna de Indicadores de Eco-Eficiência

\begin{tabular}{|c|l|l|l|l|}
\hline Item & Indicadores de eco-eficiência & Unidade & Passado & Atual \\
\hline & & & & \\
\hline & & & & \\
\hline
\end{tabular}

7.9.2 O modelo da Tabela 5 pode ser utilizado pelo Instituto Brasileiro de Siderurgia para o levantamento dos indicadores de eco-eficiência das indústrias siderúrgicas no Brasil.

Tabela 5 - Indicadores de Eco-Eficiência das Indústrias Siderúrgicas no Brasil

\begin{tabular}{|l|l|l|l|l|l|}
\hline \multirow{2}{*}{ Item } & \multirow{2}{*}{ Indicadores de eco-eficiência } & \multirow{2}{*}{ Unidade } & \multicolumn{3}{|c|}{ Siderúrgicas no Brasil } \\
\cline { 4 - 6 } & & & A & B & C \\
\hline & & & & & \\
\hline
\end{tabular}

7.9.3 O modelo da Tabela 6 pode ser utilizado por organismos internacionais para estudo comparativo dos indicadores de eco-eficiência das indústrias siderúrgicas a nível mundial.

Tabela 6 - Indicadores de Eco-Eficiência das Indústrias Siderúrgicas a Nível Mundial

\begin{tabular}{|c|c|c|c|c|c|c|}
\hline Item & Indicadores de eco-eficiência & Unidade & Brasil & UE & EUA & Japão \\
\hline & & & & & & \\
\hline & & & & & & \\
\hline
\end{tabular}

Legenda: UE - União Européia

EUA - Estados Unidos da América. 


\subsection{Da Entrevista com os Gestores de SMS (Quadro 13), algumas recomendações podem ser feitas para a alta direção:}

7.10.1 Buscar as certificações dos sistemas de gestão rumo ao desenvolvimento sustentável e responsabilidade social.

7.10.2 Desenvolver programas de qualificação e certificação de fornecedores de produtos e serviços.

7.10.3 Introduzir o benchmarking interno e externo nos sistemas de gestão de SMS.

7.10.4 Ampliar o código de ética para os stakeholders.

7.10.5 Aprimorar a participação jurídica nos níveis operacionais.

7.10.6 Divulgar o balanço social da indústria, voluntariamente, para o público.

7.10.7 Alocar recursos para o desenvolvimento de projetos em parceria com as universidades e centros de pesquisas.

\subsection{Recomendação Geral}

Um trecho do texto de Edson Vaz Musa, Presidente do Conselho Curador da FPNQ aos executivos, reforça a tese de que as indústrias geridas com os princípios da excelência na gestão terão níveis cada vez mais altos de desempenho.

É certo que para melhorar a eficiência e a eficácia da indústria, precisamos ter uma visão e uma abordagem sistêmica da gestão, além de ter empresas que, tratando de todos os stakeholders, sejam socialmente responsáveis. Sabemos que para ser competitivos temos que investir em "capital social" (pessoas, conhecimento, cultura, instituições e etc.) e assim, estaremos aptos a ingressar num ciclo virtuoso de maior criatividade, inovação, competitividade, criação de valor agregado e de geração de riqueza com eqüidade social. 
O empresário, o executivo ou a força de trabalho conscientes desta realidade e que querem gerir sua empresa, seus recursos, seus negócios, ou suas atividades, na busca constante da excelência precisam de um instrumento de medição, posto que só sabemos gerir o que sabemos medir.

Neste aspecto, recomenda-se adotar os critérios de excelência do Prêmio Nacional da Qualidade como uma ferramenta fantástica para as indústrias medirem suas performances, pois constituem um modelo sistêmico de gestão adotado mundialmente por inúmeras organizações que buscam alcançar níveis de desempenho comparáveis aos padrões internacionais, considerados de classe mundial. 


\section{SUGESTÕES PARA TRABALHOS FUTUROS}

- Criar um instituto de tecnologia em sistemas de gestão para a excelência empresarial e desenvolvimento sustentável.

- Integrar o gerenciamento de riscos com os sistemas de gestão de saúde, meio ambiente e segurança do trabalho.

- Desenvolver uma metodologia para a integração dos sistemas de gestão da qualidade, saúde, meio ambiente, segurança do trabalho e responsabilidade social.

- Implementar os indicadores de eco-eficiência na indústria siderúrgica. 


\section{REFERÊNCIAS BIBLIOGRÁFICAS}

ABIQUIM Associação Brasileira da Indústria Química. Atuação Responsável. [on line] disponível em http://www.abiquim.org.br/conteudo.asp?princ=atu\&pág= prog [2003 Dezembro 19].

ABNT Associação Brasileira de Normas Técnicas. Diretrizes Gerais sobre Princípios, Sistemas e Técnicas de Apoio. ABNT NBR ISO 14004, Rio de Janeiro; 1996.

ABNT Associação Brasileira de Normas Técnicas. Sistemas de Gestão Ambiental. ABNT NBR ISO 14001, Rio de Janeiro; 1996.

ABNT Associação Brasileira de Normas Técnicas. Sistemas de Gestão da Qualidade - Fundamentos e Vocabulário. ABNT NBR ISO 9000, Rio de Janeiro; 2000.

Abreu D. Sem ela, nada feito: Educação Ambiental e a ISO 14001. Salvador, BA: Casa da Qualidade; 2000.

Aquino JD, Philippi A. Adoção de Certificação de Sistemas de Gestão de Segurança e Saúde no Trabalho no Setor Petroquímico Brasileiro. V Simpósio de Gerenciamento Ambiental na Indústria - NISAM; 2002.

Banks J. Principles of Quality Control. New York, John Wiley $\varepsilon$ Sons; 1989.

Batista FF. Elaboração de Indicadores de Desempenho Industrial. IBGE, Brasília-DF; 2001.

BEAC Board of Environmental Health $\varepsilon$ Safety Auditor Certifications. Standards for the Professional Practice of Environmental, Health and Safety Auditing. Florida; BEAC; 1999. 
Berlo DK. O Processo de Comunicação. São Paulo: Martins Fontes; 1999.

Bernstein, PL. Desafio aos Deuses. $9^{\text {a }}$ Edição, New York; Editora Campus; 1997 (Tradução Autorizada por John Wiley $\varepsilon$ Sons).

Bicudo VR, Tenório FG. O Impacto de Modelos de Gestão nas Relações de Trabalho e nos Riscos à Saúde dos Trabalhadores: em Busca de Formas Gerenciais Participativas. Revista de Administração Pública. Vol. 33(4); 117 20; Julho-Agosto 1999.

Bird FE, Loftus RG. Loss Control Management. Georgia, USA: Institute Press; 1976.

BSI British Standards Institution. Occupational Health and Safety Management Systems. BS 8800: London; 1996.

Bureau Veritas do Brasil. Sistema de Gestão de Segurança e Saúde Ocupacional. $4^{\mathrm{a}}$ Ed., São Paulo; 2003.

CEPAA Council on Economic Priorities Accreditation Agency. Codes of Conduct and the Needs for International Standards. [on-line] Disponível em http://www.cepaa.org/introduction.htm $>$ [2002 Maio 5].

Chehebe, JRB. Análise do Ciclo de Vida de Produtos. Ferramenta Gerencial da ISO 14000. Rio de Janeiro, Qualimark Editora; 2002.

Corbett e Col. Rolls for the Metalworking Industries. USA. Iron and Steel Society; 1990.

Dijken KV, Prince Y, Wolters T, Frey M, Mussati G, Kalff P, et. al. Adoption of Environmental Innovations. Dordrecht, Netherlands: Kluwer Academic Publishers; 1999. 
Ferraz E, Gestão de Risco no Século XXI. Quem não arrisca não petisca. Revista Exame, edição de 03 de Abril de 2002.

Fonseca AVM. Análise de Desempenho de Empresas com o uso do Modelo Lispel. São Paulo; 1996. [Dissertação apresentada à Escola Politécnica da USP para obtenção do título de Mestre em Engenharia].

FPNQ Fundação para o Prêmio Nacional da Qualidade. Critérios de Excelência. O Estado da Arte da Gestão para a Excelência do Desempenho. São Paulo: FPNQ; 2000, 2002.

Franco T, Druck G. Padrões de Industrialização, Riscos e Meio Ambiente. Ciência Saúde Coletiva; 3(2) : 61-72; 1998.

Freitas CM, Porto MFS e Machado JMH. Acidentes Industriais Ampliados. Desafios e Perspectivas para o Controle e a Prevenção. Rio de Janeiro, Editora Fiocruz; 2000.

Friedman FB. Practical Guide to Environmental Management. $6^{\mathrm{a}}$ Edition, Washington, DC; 1995.

Galvão Filho, JB. Gestão de Risco Ambiental. Revista Banas Ambiental. Edição Especial em Junho de 2001.

Gilbert MJ. Sistema de Gerenciamento Ambiental. São Paulo: Iman; 1995.

Hoeppner MC. Normas Regulamentadoras Relativas à Segurança e Medicina do Trabalho (Capitulo V, Título II, da CLT). Editora Ícone. São Paulo; 2003.

Houaiss. Dicionário Houaiss da Língua Portuguesa. Instituto Antônio Houaiss. Rio de Janeiro, Editora Objetiva; 2001. 
ICHEME Institution of Chemical Engineers. Safety Management Systems. $2^{a}$ Ed. Warwickshire UK: Galiard; 1994.

ILO International Labour Office. ILO Estimates over 1 Million Work-Related Fatalities each Year. Workplace Hazards Envolving as Techonologies Develop. [on line] disponivel em www.ilo.org/public/english/bureau/inf/pm1999/9.html [2001 Março 26].

Instituto Brasileiro de Siderurgia. Anuário Estatístico. Brazil Steel Databook. Rio de Janeiro: IBS; 2003.

ISO International Standard Organization. Environmental Performance Evaluation Guidelines. ISO 14031, Genebra; 1999.

ISO/DIS International Organization for Standardization / Draft International Standard. Guidelines on Quality and/or Environmental Management Systems Auditing. Geneva-Switzerland: ISO; 2002.

Kisil M. Gestão da Mudança Organizacional. São Paulo; 1998.

Knode TL, Albernathy SE. Improving Performance and Managing Risk by Full Integration of HSE and Quality into Business Delivery Process. Halliburton Energy Services; Society of Petroleum Engineers; September 2000.

Krut R, Gleckman H. ISO 14001 a Missed Opportunity for Sustainable Global Industrial Development. London: Earthscan; 1998.

Less FP. Loss Prevention in the Process Industries. $2^{\mathrm{a}}$ ed. Vol. 1. Oxford: Butterworth-Heinemann; 1996.

Lindsay FD. Successful Health and Safety Management. The Contribution of Management Audit. Safety Science; 15 : 387-402; 1992. 
Lucchese, Patrícia TR. Informação para a Tomada de Decisão. [on line] disponível em www.saudepublica.bvs.br [2003 Setembro 06].

Luna SV. Planejamento de Pesquisa. São Paulo: Educ; 2002.

Mackau, Dirk. SME Integrated Management Systems: A Proposed Experiences Model. Vol. 15 Number 1 : 43-51; Esmerald Research Register; Aachen University, Germany; 2003.

MCT Ministério da Ciência e Tecnologia. Movimento Brasil Competitivo. [on line] disponível em http://www.mbc.org/indicadores /indicadores.asp [2003 Maio 19].

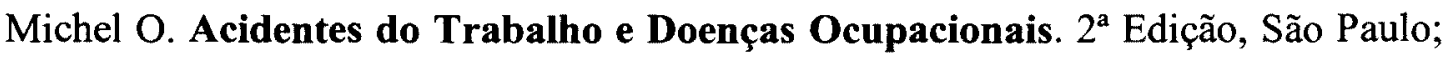
LTr; 2001.

Minayo MCS. O Desafio do Conhecimento. Pesquisa Qualitativa em Saúde. $6^{a}$ edição, São Paulo - Rio de Janeiro: Hucitec - Abrasco; 1999

MMA Ministério do Meio Ambiente. Estratégias de Elaboração e Implementação da Agenda 21 Brasileira. Gestão de Recursos. [on-line] Disponível em http://www.mma.gov.br/port/se/agen21bra/corpo.html [2002 Dezembro 12].

Moran G, Spanner J. The Importance of Standardization. Materials Evaluation; Norfolk, Vol. 54 nº; 901-904; 1996.

Moreira MS. Estratégia e Implantação do Sistema de Gestão Ambiental. Belo Horizonte: Desenvolvimento Gerencial; 2001.

Moura LAA. Qualidade e Gestão Ambiental. $2^{\mathrm{a}}$ ed. São Paulo: Juarez de Oliveira; 2000. 
MPAS - Ministério da Previdência e Assistência Social. Anuário Estatístico da Previdência Social 2001. Seção IV Acidentes do Trabalho. [on line] disponível em http://www.mpas.gov.br/12_01_03_01.asp [2002 Dezembro 30].

MTE Normas Regulamentadoras de Segurança e Saúde no Trabalho. [on-line] disponível em http://www.mte.gov.br/sit/nrs/nrsidx.htm> [2001 Abril 11)

Nardocci AC. Risco como Instrumento de Gestão Ambiental. São Paulo; 1999. [Tese apresentada à Faculdade de Saúde Pública da USP para a obtenção do Título de Doutor em Saúde Pública. Área de Concentração: Saúde Ambiental].

Norival P. Análise de Risco Ambiental de Processo Siderúrgico. São Paulo; 1998 [Tese apresentada à Faculdade de Saúde Pública da USP para a Obtenção do Título de Doutor em Saúde Pública. Área de Concentração: Saúde Ambiental].

OHSAS Occupational Health and Safety Assessment Series. Diretrizes para a Implementação da OHSAS 18001. OHSAS 18002, São Paulo: Risk Tecnologia; 2001.

OHSAS Occupational Health and Safety Assessment Series. Especificação para Sistemas de Gestão da Segurança e Saúde no Trabalho. OHSAS 18001, São Paulo: Risk Tecnologia; 2001.

OHSAS Occupational Health and Safety Assessment Series. Occupational Health and Safety Management Systems - Specification. OHSAS 18001, London: BSI; 1999.

Oliver Wight International. The Oliver Wight ABCD Check List for Operational Excelence. Fifth Edition, New York, John Wiley $\varepsilon$ Sons; 2000. 
PEERCENTER Public Entity Environmental Management System Resource Center. How to Implement an EMS. [on-line] Disponível em http://www.peercenter.net/howtoimplement/gettingready.cfm [2002 Agosto 02].

Porter, M. O Melhor do Pensamento Contemporâneo em Gestão Empresarial. Coletânea HSM Management; Folha de São Paulo de 15 de Junho de 2003.

QSP Centro da Qualidade, Segurança e Produtividade para o Brasil e América Latina. Pesquisa 2003 sobre Sistemas Integrados de Gestão. [on line] disponível em http://www.qsp.org.br/faame.php ${ }^{2}$.p/ultimas51.htm [2003 Junho 04].

RGE Rio Grande Energia. Gestão de Segurança e Controle de Perdas. [on line] Disponivel em www.rge-rs.com.br/gestao seguranca/excelencia.htm [2004 Janeiro 10].

Ribeiro MS. Ações das Empresas para a Preservação do Meio Ambiente. Vol. 415, p. 3-4; Sistema de Informação ABRASCA; 1998.

Rigotto RM e Almeida VL. Capacitando Profissionais em Saúde, Trabalho e Meio Ambiente. Ciência e Saúde Coletiva. 3(2):163-170, 1998.

SAI Social Accountability International. Responsabilidade Social 8000. SAI SA 8000, New York; 2001.

Secretaria do Meio Ambiente. ISO 14000 Sistema de Gestão Ambiental, Volume XIV. Entendendo o Meio Ambiente. São Paulo; 1997.

Sharratt P. Environmental Management Systems. Institution of Chemical Engineers; 1995. 
Silva RG. Auditorias Internas do Sistema de Gestão da Segurança e Saúde no Trabalho. Estudo de caso em um Terminal Químico para Líquidos a Granel. São Paulo; 2002. [Dissertação apresentada à FSP/USP para obtenção do título de Mestre em Saúde Pública].

Taralli G. Sistemas Integrados de Gestão do Meio Ambiente e de Segurança e Saúde no Trabalho como Fator de Inovação Tecnológica. São Paulo; 2001 [Tese apresentada à Escola Politécnica da USP para a Obtenção do Título de Doutor em Engenharia. Área de Concentração: Engenharia Química].

Tundisi JG. Bases Ecológicas para o Desenvolvimento Sustentado. In: Academia de Ciências do Estado de São Paulo. Desenvolvimento Sustentado: Problemas e Estratégias. São Paulo: Castellano; 1998, p. 24-29.

West GA, Michand RW. Principles of Environmental, Health and Safety Management. Rockville, Maryland: Government Institutes; 1995. 


\section{WEBSITES}

$\underline{\text { www.aguaonline.com.br/ }}$

www.ana.gov.br/

www.abiquim.org.br/

www.abnt.org.br/

www.abrh.org.br/

www.bsi.org.uk/

www.cepaa.org/

www.cetesb.sp.gov.br/

www.ciit.org/
Águaonline.

Revista digital da água, do saneamento e do meio ambiente.

Agência Nacional de Águas.

Gestão das águas.

Associação Brasileira da Indústria Química.

Atuação Responsável.

Associação Brasileira de Normas Técnicas.

Órgão Responsável pela Normalização Técnica no Brasil.

Associação Brasileira de Recursos Hídricos Lei $\mathrm{n}^{\mathbf{o}}$ 9.433 e Código de Águas.

"British Standards Institution".

Organismo de Normalização do Reino Unido.

"Council on Economic Priorities Accreditation Agency".

Responsabilidade Social Internacional.

Companhia Estadual de Tecnologia de Saneamento Ambiental.

Ciência e Tecnologia a Serviço do Meio Ambiente.

"Center for Health Research"

Pesquisa Científica e Educação em Saúde Ambiental. 
www.econ.fea.usp.br/

www.epa.gov/

www.eurofound.ie/

www.fplc.educ/

www.fpnq.org.br/

www.fundacentro.gov.br/

www.ibama.gov.br/

www.ibs.org.br/

www.inmetro.gov.br/
Faculdade de Economia, Administração e Contabilidade da USP.

Comércio e Desenvolvimento.

"U.S. Environmental Protection Agency"

Saúde Humana e Meio Ambiente.

"European Foundation for the Improvement of Living and Working Conditions".

Qualidade de Vida.

"Franklin Pierce Law Center".

Saúde, Legislação e Ética.

Fundação para o Prêmio Nacional da Qualidade.

Excelência na Gestão das Organizações.

Fundação Jorge Duprat Figueiredo, de Segurança e Medicina do Trabalho.

Links de Segurança e Saúde no Trabalho.

Instituto Brasileiro do Meio Ambiente e dos Recursos Naturais e Renováveis.

Links Ambientais.

Instituto Brasileiro de Siderurgia. Produção de Aço.

Instituto Nacional de Metrologia, Normalização e Qualidade Industrial.

Credenciamento de Laboratórios, Organismos de Certificação e Inspeção. 
www.iso.ch/

www.mma.gov.br/

www.mpas.gov.br/

www.mre.gov.br/

www.mtb.gov.br/
"International Organization for Standardization".

Normas ISO Internacionais.

Ministério do Meio Ambiente.

Agenda 21 Brasileira.

Ministério da Previdência e Assistência Social

Estatísticas de Acidentes do Trabalho.

Ministério das Relações Exteriores Temas da Agenda Internacional.

Ministério do Trabalho e Emprego.

Links de Segurança e Saúde do Trabalho.

www.mtb.gov.br/temas/segsau/legislação/normas/default.asp

Normas Regulamentadoras de Segurança e Saúde no Trabalho.

Links da Legislação Trabalhista.

www.oit.org/

"International Labour Organization".

Normas e Princípios Fundamentais.

Direitos Trabalhistas.

www.oliverwight.co.uk/home.asp "Oliver Wight International".

Excelência Empresarial.

www.osha.gov/

"U.S. Department of Labor".

"Occupational Safety $\varepsilon$ Health Administration".

Segurança e Saúde dos Trabalhadores Americanos. 
www.peercenter.net/

www.poli.usp.br/

$\underline{\text { www.prossiga.br/ }}$

www.qsp@asp.org.br/

www.rma.org.br/

www.saber.usp.br/

www.saudepublica.bvs.br/

www.seade.gov.br/
"Public Entity Environmental Management System Resource Center".

Gestão Ambiental para Órgãos Públicos.

Escola Politécnica da USP.

Mestrado e Doutorado em Engenharia.

Informação e Comunicação para Ciência e Tecnologia.

Bibliotecas Virtuais Temáticas.

Centro da Qualidade, Segurança e Produtividade

Pesquisa sobre Sistemas de Gestão Integrada.

Rede de $O N G$ 's da Mata Atlântica.

Representação da Sociedade Civil.

O Portal do Conhecimento.

Biblioteca digital de teses e dissertações da USP.

Biblioteca Virtual em Saúde.

Pesquisa Livre.

Fundação Sistema Estadual de Análise de Dados.

Índice Paulista de Responsabilidade Social.

www.sindusfarma.org.br/ Sindicato da Indústria de Produtos Farmacêuticos no Estado de São Paulo.

Boas Práticas de Fabricação.

www.who.int/en/
"World Health Organization".

Links de Saúde. 


\section{ANEXOS}

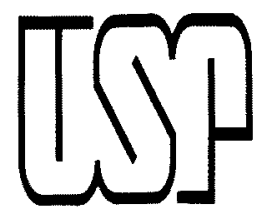

UNIVERSIDADE DE SÃO PAULO FACULDADE DE SAÚdE PÚBLICA

PROGRAMA DE PÓS-GRADUAÇÃO EM SAÚDE PÚBLICA

AREA DE CONCENTRAÇÃO - SAÚDE AMBIENTAL

\section{EMPRESA:}

ENDEREÇO:

\section{FONE:}

FAX:

LINHA DE PRODUTO DA EMPRESA:

CAPACIDADE DE PRODUÇÃO ( TON./ANO ):

NÚMERO DE FUNCIONÁRIOS: $\mathrm{MOD}=\quad \mathrm{MOI}=\quad \mathrm{SMS}=$

ESTRUTURA ORGANIZACIONAL DE SMS

A EMPRESA POSSUI QUAIS CERTIFICAÇÕES:
( ) NBR-ISO 9001:2000
( ) OHSAS 18001:1999
( ) NBR-ISO 14001:1996
( ) BS $8800: 1996$
OUTRAS ( especificar ) :

NOME DO RESPONSÁVEL:

CARGO E FUNÇÃO NA EMPRESA:

TEMPO DE EXPERIÊNCIA PROFISSIONAL:

NA ÁREA SMS:

E-MAIL:

FONE: 
1. Quais são os principais fatores positivos de SMS associados com a eficiência operacional da indústria?

Relacionar os fatores em ordem crescente de importância, através da atribuição de pontos até que a soma atinja 100 . Você pode acrescentar ou modificar a tabela de fatores.

\section{FATOR}

\begin{tabular}{|c|l|c|}
\hline ITEM & \multicolumn{1}{|c|}{ POSITIVO } & PONTOS \\
\hline 1 & Desenvolvimento de uma estrutura de gestão SMS & \\
\hline 2 & Proatividade nas ações de gestão SMS & \\
\hline 3 & $\begin{array}{l}\text { Prevenção de impactos ambientais, riscos de acidentes e doenças } \\
\text { ocupacionais }\end{array}$ & \\
\hline 4 & Mudança da cultura organizacional & \\
\hline 5 & Melhoria da imagem pública & \\
\hline 6 & Melhoria nas relações com órgãos regulamentadores & \\
\hline 7 & Capacidade intelectual para encontrar requisitos legais & \\
\hline 8 & $\begin{array}{l}\text { Conscientização e comprometimento da força de trabalho para a } \\
\text { eco-eficiência da indústria }\end{array}$ & \\
\hline 9 & Envolvimento do alto executivo da empresa & \\
\hline 10 & $\begin{array}{l}\text { Racionalização da alocação de recursos humanos, fisicos e } \\
\text { financeiros }\end{array}$ & \\
\hline 11 & Redução dos custos operacionais pela eliminação de desperdícios & \\
\hline 12 & Redução do valor do seguro da planta industrial & \\
\hline 13 & Redução de passivos ambientais e trabalhistas & \\
\hline 14 & $\begin{array}{l}\text { Redução dos custos de matéria prima pela introdução de } \\
\text { programas de reutilização e reciclagem }\end{array}$ & \\
\hline 15 & Padronização de atividades & \\
\hline & Outros (especificar ) & \\
\hline 16 & & \\
\hline 17 & & \\
\hline 18 & & \\
\hline 19 & & \\
\hline & & \\
\hline
\end{tabular}

\section{COMENTÁRIOS:}


2. Como os principais fatores positivos de SMS afetam a eficiência operacional da indústria?

\begin{tabular}{|c|c|}
\hline & FATOR POSITIVO DE SMS \\
\hline ITEM & COMO AFETAM A EFICIÊNCIA OPERACIONAL \\
\hline 1 & \\
\hline 2 & \\
\hline 3 & \\
\hline 4 & \\
\hline 5 & \\
\hline 6 & \\
\hline 7 & \\
\hline 8 & \\
\hline 9 & \\
\hline 10 & \\
\hline 11 & \\
\hline 12 & \\
\hline 13 & \\
\hline 14 & \\
\hline 15 & \\
\hline 16 & \\
\hline 17 & \\
\hline 18 & \\
\hline 19 & \\
\hline
\end{tabular}

COMENTÁRIOS: 
3. Quais são os principais fatores negativos de SMS associados com a eficiência operacional da indústria?

Relacionar os fatores em ordem crescente de importância, através da atribuição de pontos até que a soma atinja 100 . Você pode acrescentar ou modificar a tabela de fatores.

\begin{tabular}{|c|c|c|}
\hline \multicolumn{3}{|c|}{ FATOR } \\
\hline ITEM & NEGATIVO & PONTOS \\
\hline 1 & $\begin{array}{l}\text { Baixo nivel de responsabilidade e envolvimento da força de } \\
\text { trabalho com SMS }\end{array}$ & \\
\hline 2 & $\begin{array}{l}\text { Falta de reconhecimento de SMS como uma das prioridades da } \\
\text { empresa }\end{array}$ & \\
\hline 3 & $\begin{array}{l}\text { A falta de sistematização para avaliação do cumprimento dos } \\
\text { princípios de desenvolvimento sustentável }\end{array}$ & \\
\hline 4 & $\begin{array}{l}\text { A falta de regulamentação para a divulgação pública do } \\
\text { desempenho de SMS da empresa }\end{array}$ & \\
\hline 5 & Divulgação da certificação ( marketing ) & \\
\hline 6 & A escolha pela empresa do organismo credenciado de certificação & \\
\hline 7 & $\begin{array}{l}\text { O padrão normativo equivalente não é exigência para os } \\
\text { fornecedores }\end{array}$ & \\
\hline 8 & $\begin{array}{l}\text { A equipe de SMS não está preparada para dar suporte amplo aos } \\
\text { negócios }\end{array}$ & \\
\hline 9 & Riscos de operação e capital sobre SMS & \\
\hline 10 & Multas de órgãos públicos de fiscalização & \\
\hline 11 & $\begin{array}{l}\text { Ações trabalhistas decorrentes de condições inadequadas de } \\
\text { saúde e segurança do trabalho }\end{array}$ & \\
\hline & Outros ( especificar) & \\
\hline 12 & & \\
\hline 13 & & \\
\hline 14 & & \\
\hline 15 & & \\
\hline
\end{tabular}

\section{COMENTÀRIOS:}


4. Como os principais fatores negativos de SMS afetam a eficiência operacional da indústria?

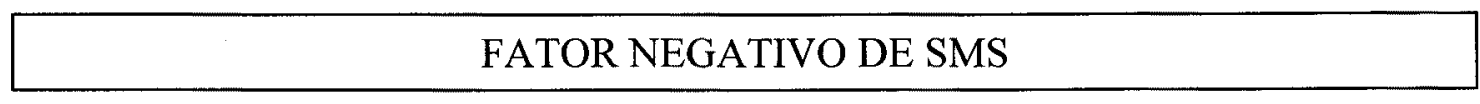

\begin{tabular}{|c|c|}
\hline ITEM & COMO AFETAM A EFICIÊNCIA OPERACIONAL \\
\hline 1 & \\
\hline 2 & \\
\hline 3 & \\
\hline 4 & \\
\hline 5 & \\
\hline 6 & \\
\hline 7 & \\
\hline 8 & \\
\hline 9 & \\
\hline 10 & \\
\hline 11 & \\
\hline 12 & \\
\hline 13 & \\
\hline 14 & \\
\hline 15 & \\
\hline
\end{tabular}

COMENTÁRIOS: 
5. Quais são os principais benefícios da implantação de Sistemas de Gestão SMS ? Relacionar as vantagens em ordem crescente de importância, através da atribuição de pontos até que a soma atinja 100. Você pode acrescentar ou modificar a tabela de fatores.

\begin{tabular}{|c|c|c|}
\hline \multicolumn{3}{|c|}{ IMPLANTAÇÃO DE SISTEMAS DE GESTÃO SMS } \\
\hline ITEM & BENEFÍCIOS & PONTOS \\
\hline 1 & Integração de políticas, programas e procedimentos & \\
\hline 2 & Posição estratégica clara para o mercado & \\
\hline 3 & $\begin{array}{l}\text { Gestão das atividades em conformidade com os requisitos da } \\
\text { empresa, legais, estatutários e regulamentares }\end{array}$ & \\
\hline 4 & Levantamento sistematizado do histórico de problemas & \\
\hline 5 & $\begin{array}{l}\text { O nível gerencial é responsável pela efetividade da implantação } \\
\text { de SMS }\end{array}$ & \\
\hline 6 & Os Sistemas de Gestão representam as práticas da empresa & \\
\hline 7 & Melhoria nas relações com órgãos públicos & \\
\hline 8 & Benefícios intangíveis & \\
\hline 9 & Envolvimento do pessoal operacional & \\
\hline \multirow[t]{5}{*}{10} & Ciclo de retroalimentação e mecanismos de avaliação de SMS & \\
\hline & Outros (especificar) & \\
\hline & & \\
\hline & & \\
\hline & TOTAL & 100 \\
\hline
\end{tabular}

COMENTÁRIOS: 
6. Quais são as principais dificuldades da implantação de Sistemas de Gestão SMS ?

Relacionar as desvantagens em ordem crescente de importância, através da atribuição de pontos até que a soma atinja 100. Você pode acrescentar ou modificar a tabela de fatores.

\begin{tabular}{l}
\hline \multicolumn{3}{|c|}{ IMPLANTAÇÃO DE SISTEMAS DE GESTÃO SMS } \\
\begin{tabular}{|c|l|c|}
\hline ITEM & \multicolumn{1}{|c|}{ DIFICULDADES } & PONTOS \\
\hline 1 & Custo elevado & \\
\hline 2 & Sistema formal documentado em detalhe & \\
\hline 3 & Falta de experiência da equipe de SMS & \\
\hline 4 & $\begin{array}{l}\text { É necessário um grande aporte de conhecimento em um período } \\
\text { de tempo curto }\end{array}$ & \\
\hline 5 & $\begin{array}{l}\text { Elaboração de documentos normativos sem a participação da } \\
\text { força de trabalho }\end{array}$ & \\
\hline 6 & Resistência a mudanças & \\
\hline 7 & Terminologia e documentos de dificil entendimento & \\
\hline 8 & Múltiplas fontes de informações & 100 \\
\hline & Outros (especificar) & \\
\hline 9 & & \\
\hline 10 & & TOTAL \\
\hline 11 & & \\
\hline 12 & & \\
\hline & & \\
\hline
\end{tabular}
\end{tabular}

COMENTÁRIOS: 
7. Quais são os principais benefícios da Manutenção de Sistemas de Gestão SMS? Relacionar as vantagens em ordem crescente de importância, através da atribuição de pontos até que a soma atinja 100. Você pode acrescentar ou modificar a tabela de fatores.

\section{MANUTENÇAO DE SISTEMAS DE GESTÃO SMS}

\begin{tabular}{|c|l|c|}
\hline ITEM & \multicolumn{1}{|c|}{ BENEFÍCIOS } & PONTOS \\
\hline 1 & Influencia os valores e visão da empresa & \\
\hline 2 & Auxilia a empresa a alcançar seus objetivos e metas & \\
\hline 3 & Cria um espírito de auto disciplina & \\
\hline 4 & $\begin{array}{l}\text { Norteia as atividades da empresa pelo princípio da atuação } \\
\text { responsável e desenvolvimento sustentável }\end{array}$ & \\
\hline 5 & $\begin{array}{l}\text { Incentiva programas de melhoria e economia de energia nos } \\
\text { processos }\end{array}$ & \\
\hline 6 & Mudança no perfil tecnológico da empresa & \\
\hline 7 & Compromisso com a melhoria contínua & \\
\hline 8 & Define o que e como fazer nos assuntos de SMS & \\
\hline 9 & Procedimentos adotados para análise laboratoriais & \\
\hline 10 & Auditoria de conformidade legal & 100 \\
\hline & Outros (especificar) & \\
\hline 11 & & \\
\hline 12 & TOTAL & \\
\hline 13 & & \\
\hline 14 & & \\
\hline & & \\
\hline
\end{tabular}

\section{COMENTÁRIOS:}


8. Quais são as principais dificuldades da Manutenção de Sistemas de Gestão SMS ?

Relacionar as desvantagens em ordem crescente de importância, através da atribuição de pontos até que a soma atinja 100. Você pode acrescentar ou modificar a tabela de fatores.

\begin{tabular}{|c|c|c|}
\hline \multicolumn{3}{|c|}{ MANUTENÇAO DE SISTEMAS DE GESTÃO SMS } \\
\hline ITEM & DIFICULDADES & PONTOS \\
\hline 1 & $\begin{array}{l}\text { O comprometimento dos colaboradores perde força, se não } \\
\text { houver retroalimentação pela alta gerência }\end{array}$ & \\
\hline 2 & O fluxo de informação não assegura agilidade e confiabilidade & \\
\hline 3 & $\begin{array}{l}\text { A equipe de SMS possui responsabilidade sem o nível de } \\
\text { autoridade equivalente }\end{array}$ & \\
\hline 4 & O calendário de eventos institucionais não é oficializado & \\
\hline 5 & Falta de especialistas para a melhoria de SMS & \\
\hline 6 & A política de SMS não é realista & \\
\hline 7 & $\begin{array}{l}\text { A equipe operacional não está alinhada com objetivos e metas da } \\
\text { organização }\end{array}$ & \\
\hline 8 & $\begin{array}{l}\text { As diretrizes e responsabilidades não são claramente } \\
\text { comunicadas }\end{array}$ & \\
\hline 9 & Elevado número de auditoria voluntária ou compulsória & \\
\hline \multirow[t]{2}{*}{10} & Custo elevado & \\
\hline & Outros (especificar) & \\
\hline \multicolumn{3}{|l|}{11} \\
\hline \multicolumn{3}{|l|}{12} \\
\hline \multicolumn{3}{|l|}{13} \\
\hline \multicolumn{3}{|l|}{14} \\
\hline & TOTAL & 100 \\
\hline
\end{tabular}

\section{COMENTÁRIOS:}


9. Quais os principais indicadores que medem a eficiência operacional da indústria?

Relacionar os indicadores em ordem crescente de importância, através da atribuição de pontos até que a soma atinja100. Você pode acrescentar ou modificar a tabela de indicadores.

\subsection{INDICADOR DE MATERIAL}

\begin{tabular}{|c|l|c|}
\hline ITEM & \multicolumn{1}{|c|}{ DESCRIÇÃO DO INDICADOR } & PONTOS \\
\hline 1 & Quantidade de aço laminado produzida ( ton./ano ) & \\
\hline 2 & Quantidade de sucata metálica gerada no processo (ton./ano ) & \\
\hline 3 & Quantidade de carepa gerada no processo (ton./ano ) & \\
\hline 4 & $\begin{array}{l}\text { Quantidade de resíduo classe I ( perigoso )gerada no processo } \\
\text { (ton./ano ) }\end{array}$ & \\
\hline 5 & Quantidade de material reciclado no processo (ton./ano ) & \\
\hline 6 & Quantidade de emissão de gases para a atmosfera ( ton./ano ) & \\
\hline 7 & $\begin{array}{l}\text { Quantidade de efluente enviado para corpo de água (metros } \\
\text { cúbico/ano ) }\end{array}$ & \\
\hline 8 & Quantidade de água consumida (metros cúbico/ano ) & \\
\hline & Outros (especificar) & 100 \\
\hline 9 & & \\
\hline 10 & & \\
\hline 11 & & \\
\hline 12 & & \\
\hline & & \\
\hline
\end{tabular}

COMENTÁRIOS: 


\subsection{INDICADOR DE CAPITAL HUMANO}

\begin{tabular}{|c|l|c|}
\hline ITEM & \multicolumn{1}{|c|}{ DESCRIÇÃO DO INDICADOR } & PONTOS \\
\hline 1 & $\begin{array}{l}\text { Número de hora homem de treinamento por ano ( Mão de obra } \\
\text { direta ) }\end{array}$ & \\
\hline 2 & Número de programas de SMS por ano & \\
\hline 3 & $\begin{array}{l}\text { Numero de participantes em programas de SMS por ano ( mão de } \\
\text { obra direta ) }\end{array}$ & \\
\hline 4 & Número de sugestões de SMS proposta por colaborador por ano & \\
\hline 5 & $\begin{array}{l}\text { Número de colaboradores que conhecem e praticam a política de } \\
\text { SMS da empresa }\end{array}$ & \\
\hline 6 & Número de colaboradores com a formação de auditor interno & \\
\hline 7 & Investimento em capacitação profissional & \\
\hline 8 & $\begin{array}{l}\text { Número de colaboradores com qualificação ou certificação } \\
\text { profissional }\end{array}$ & \\
\hline 9 & Grau de escolaridade dos colaboradores & \\
\hline 10 & Tempo de experiência na função & 100 \\
\hline & Outros (especificar) & \\
\hline 11 & & TOTAL \\
\hline 12 & & \\
\hline 13 & & \\
\hline 14 & & \\
\hline
\end{tabular}

\section{COMENTÁRIOS:}




\subsection{INDICADOR DE ENERGIA}

\begin{tabular}{|c|c|c|}
\hline ITEM & DESCRIÇÃO DO INDICADOR & PONTOS \\
\hline 1 & Quantidade de energia elétrica consumida ( $\mathrm{Kwh} /$ ano ) & \\
\hline 2 & $\begin{array}{l}\text { Quantidade de gás (natural, GLP, oxigênio, acetileno, nitrogênio, } \\
\text { etc.) consumida ( metros cúbico/ano) }\end{array}$ & \\
\hline \multirow[t]{2}{*}{3} & $\begin{array}{l}\text { Quantidade de combustível ( óleo, gasolina, querosene, etc. ) } \\
\text { consumida } \\
\text { ( litros/ano ) }\end{array}$ & \\
\hline & Outros ( especificar) & \\
\hline \multicolumn{3}{|c|}{ - } \\
\hline \multicolumn{3}{|l|}{6} \\
\hline \multirow{2}{*}{\multicolumn{3}{|c|}{$\frac{7}{8}$}} \\
\hline \multirow{2}{*}{\multicolumn{3}{|c|}{8}} \\
\hline & & \\
\hline & TOTAL & 100 \\
\hline
\end{tabular}

COMENTÁRIOS: 


\subsection{INDICADOR FINANCEIRO ( em R \$/ano )}

\begin{tabular}{|l|l|l|}
\hline ITEM & \multicolumn{1}{|c|}{ DESCRIÇãO DO INDICADOR } & PONTOS \\
\hline 1 & $\begin{array}{l}\text { Investimento em pesquisa para métodos de redução do consumo } \\
\text { de recursos naturais }\end{array}$ & \\
\hline 2 & Alocação de recursos para a substituição de gás CFC & \\
\hline 3 & $\begin{array}{l}\text { Investimentos para prevenir a poluição ambiental, acidentes e } \\
\text { doenças ocupacionais }\end{array}$ & \\
\hline 4 & Custo do desperdício de recursos naturais utilizados no processo & \\
\hline 5 & Custo das ações resultantes de reclamações de SMS & \\
\hline 6 & Recursos aplicados na implantação e manutenção de SMS & \\
\hline 7 & Redução do custo do seguro da planta industrial & \\
\hline 8 & Retorno de investimento em projetos de melhoria & \\
\hline 9 & Custo com acidentes e doenças do trabalho & \\
\hline 10 & Custo do desperdício de energia elétrica & \\
\hline 11 & Outros (especificar) & \\
\hline 12 & & 100 \\
\hline 13 & & \\
\hline 14 & & \\
\hline & & \\
\hline
\end{tabular}

COMENTÁRIOS: 


\subsection{INDICADOR DE CONDIÇÕES AMBIENTAIS}

\begin{tabular}{|c|c|c|}
\hline ITEM & DESCRIÇÃO DO INDICADOR & PONTOS \\
\hline 1 & $\begin{array}{l}\text { Número de aspectos e impactos ambientais significativos, } \\
\text { identificados e gerenciados. }\end{array}$ & \\
\hline 2 & $\begin{array}{l}\text { Número de riscos e perigos de saúde e segurança do trabalho } \\
\text { significativos, identificados e gerenciados. }\end{array}$ & \\
\hline 3 & $\begin{array}{l}\text { Número de acidentes e doença ocupacional por ano com e sem } \\
\text { afastamento. }\end{array}$ & \\
\hline 4 & $\begin{array}{l}\text { Número de acidentes por ano com vazamento de produtos } \\
\text { perigosos. }\end{array}$ & \\
\hline 5 & $\begin{array}{l}\text { Número de atendimento à emergência por ano ( incêndio, } \\
\text { operação anormal, etc. ) . }\end{array}$ & \\
\hline 6 & $\begin{array}{l}\text { Paralisações em horas por ano para atendimento das condições } \\
\text { ambientais exigidas para o processo }\end{array}$ & \\
\hline 7 & $\begin{array}{l}\text { Número de horas gasta em manutenção preventiva em } \\
\text { equipamentos críticos para SMS por ano. }\end{array}$ & \\
\hline 8 & Equipamentos com tecnologia de controle ambiental ( No. total) & \\
\hline 9 & Medição de ruído ( valor máximo em dB(A )) & \\
\hline 10 & Medição de calor ( temperatura de trabalho em graus Celsius ) & \\
\hline \multirow[t]{2}{*}{11} & Medição de luminosidade ( valor em Lux ) & \\
\hline & Outros ( especificar) & \\
\hline \multicolumn{3}{|l|}{12} \\
\hline \multicolumn{3}{|l|}{13} \\
\hline \multicolumn{3}{|l|}{14} \\
\hline \multicolumn{3}{|l|}{15} \\
\hline & TOTAL & 100 \\
\hline
\end{tabular}

\section{COMENTÁRIOS :}




\subsection{INDICADOR DE GESTÃO SMS}

\begin{tabular}{|c|c|c|}
\hline ITEM & DESCRIÇÃO DO INDICADOR & PONTOS \\
\hline 1 & Número de fornecedores com o Sistema de Gestão SMS & \\
\hline 2 & Número de ações corretivas e preventivas implementadas por ano & \\
\hline 3 & $\begin{array}{l}\text { Número de simulados de planos de atendimento à emergência } \\
\text { realizado por ano. }\end{array}$ & \\
\hline 4 & $\begin{array}{l}\text { Redução de energia elétrica consumida por tonelada de aço } \\
\text { produzida }\end{array}$ & \\
\hline 5 & $\begin{array}{l}\text { Redução do volume de gás consumido por tonelada de aço } \\
\text { produzida }\end{array}$ & \\
\hline 6 & $\begin{array}{l}\text { Redução do volume de combustível consumido por tonelada de } \\
\text { aço produzida }\end{array}$ & \\
\hline 7 & Redução do consumo de produtos químicos nocivos à saúde & \\
\hline 8 & $\begin{array}{l}\text { Veículos equipados com tecnologia de controle ambiental ( } \\
\text { porcentagem em relação ao número total da frota ) }\end{array}$ & \\
\hline 9 & $\begin{array}{l}\text { Investimentos em ações da gestão SMS com melhoria no } \\
\text { desempenho operacional. }\end{array}$ & \\
\hline 10 & Número de objetivos e metas de SMS alcançados no ano & \\
\hline 11 & Número de auditorias de SMS realizadas por ano & \\
\hline \multirow[t]{2}{*}{12} & $\begin{array}{l}\text { Número de requisitos legais ( leis, decretos, portarias, resolução, } \\
\text { etc.) gerenciados pela empresa }\end{array}$ & \\
\hline & Outros ( especificar) & \\
\hline \multicolumn{3}{|c|}{ 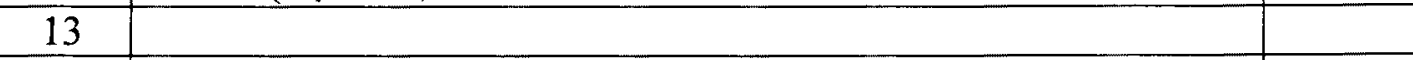 } \\
\hline \multicolumn{3}{|l|}{14} \\
\hline \multicolumn{3}{|l|}{15} \\
\hline \multicolumn{3}{|l|}{16} \\
\hline & TOTAL & 100 \\
\hline
\end{tabular}

\section{COMENTÁRIOS:}




\section{GLOSSÁRIO}

Ação Corretiva: Ação para eliminar a causa de uma não-conformidade identificada ou outra situação indesejável (ABNT NBR ISO 9000).

Ação Preventiva: Ação para eliminar a causa de uma potencial não-conformidade ou outra situação potencialmente indesejável (ABNT NBR ISO 9000).

Acidente: Evento indesejável que resulta em morte, doença, lesão, dano ou outras perdas (OHSAS 18001).

Análise Crítica: Atividade realizada para determinar a pertinência, a adequação e a eficácia do que está sendo examinado, para alcançar os objetivos estabelecidos (ABNT NBR ISO 9000).

Aplicação: Refere-se à disseminação e ao uso das práticas de gestão (FPNQ 2002).

Aspecto Ambiental: Elemento das atividades, produtos ou serviços de uma organização que pode interagir com o meio ambiente (ABNT NBR ISO 14001).

Auditoria: Processo sistemático, documentado e independente, para obter evidência da auditoria e avaliá-la objetivamente para determinar a extensão na qual os critérios de auditoria são atendidos (ABNT NBR ISO 9000).

Avaliação de risco: Processo global de estimar a magnitude do risco e decidir se o mesmo é ou não tolerável (OHSAS 18001).

Benchmarking: Ver comparação com as melhores práticas.

Classe Mundial: Sistemas de Gestão com resultados comparáveis aos referenciais de excelência (FPNQ 2002). 
Comparação com as melhores práticas (Benchmarking): Processo contínuo de comparação de práticas de gestão, que pode incluir a comparação de estratégias, procedimentos, operações, sistemas, processos, produtos e serviços. Essa comparação é feita com organizações líderes reconhecidas no mercado, inclusive com líderes de ramos de atividade diferentes da organização, para identificar as oportunidades para melhoria do desempenho (FPNQ 2002).

Competência: Mobilização de conhecimentos (saber), habilidades (fazer) e atitudes (querer) necessárias ao desempenho de atividades ou funções, segundo padrões de qualidade e produtividade requeridos pela natureza do trabalho (FPNQ 2002).

Desempenho (Performance): Resultados obtidos dos principais indicadores de processos e de produtos que permitem avaliá-los e compará-los em relação às metas, aos padrões, aos referenciais pertinentes e a outros processos e produtos. Mais comumente, os resultados expressam satisfação, insatisfação, eficiência e eficácia e podem ser apresentados em termos financeiros ou não (FPNQ 2002).

Desempenho Ambiental: Resultados mensuráveis do sistema de gestão ambiental, relativos ao controle de uma organização sobre seus aspectos ambientais, com base na sua política, seus objetivos e metas ambientais (ABNT NBR ISO 14001).

Eficácia: Extensão na qual as atividades planejadas são realizadas e os resultados planejados, alcançados (ABNT NBR ISO 9000).

Eficiência: Relação entre o resultado alcançado e os recursos usados (ABNT NBR ISO 9000). Virtude ou característica de (uma pessoa, um maquinismo, uma técnica, um empreendimento, etc.) conseguir o melhor rendimento com o mínimo de erros e/ou dispêndio de energia, tempo, dinheiro ou meios. Produtividade econômica; rendimento (HOUAISS 2001).

Enfoque: Refere-se às práticas de gestão utilizadas para atender aos requisitos normativos de SMS (FPNQ 2002). 
Gestão: Atividades coordenadas para dirigir e controlar uma organização (ABNT NBR ISO 9000).

Impacto Ambiental: Qualquer modificação do meio ambiente, adversa ou benéfica, que resulte, no todo ou em parte, das atividades, produtos ou serviços de uma organização (ABNT NBR ISO 14001).

Implantação: Iniciar e promover o desenvolvimento de algo (ex. um processo) (HOUAISS 2001).

Implementação: Pôr em execução, pôr em prática (plano, programa ou projeto) (HOUAISS 2001).

Incidente: Evento que resultou em acidente ou que teve o potencial de resultar em acidente (OHSAS 18001).

Indicadores: Dados ou informações numéricas que quantificam as entradas (recursos ou insumos), saídas (produtos) e o desempenho de processos, produtos e da organização como um todo. Os indicadores são utilizados para acompanhar e melhorar os resultados ao longo do tempo (FPNQ 2002).

Inovação: Mudança nas práticas de gestão e padrões de trabalho existentes com a introdução de novos conceitos, idéias, atitudes, dentre outras (FPNQ 2002).

Meio Ambiente: Circunvizinhança em que uma organização opera, incluindo ar, água, solo, recursos naturais, flora, fauna, seres humanos e suas inter-relações (ABNT NBR ISO 14001).

Melhoria Contínua: Atividade recorrente para aumentar a capacidade de atender requisitos (ABNT NBR ISO 9000). 
Metas: Niveis de desempenho pretendido para um determinado periodo de tempo (FPNQ 2002).

Não-conformidade: Não atendimento a um requisito (ABNT NBR ISO 9000).

Operacional: Pronto para utilização ou para funcionar; que contribui para obtenção de um resultado pretendido (HOUAISS 2001).

Organização: Companhia, corporação, firma, órgão, instituição ou empresa, ou uma unidade destas, pública ou privada, sociedade anônima, limitada ou com outra forma estatutária, que tem funções e estruturas administrativas próprias e autônomas, no setor público ou privado, com ou sem finalidade de lucro, de porte pequeno, médio ou grande (FPNQ 2002).

Partes Interessadas (Stakeholder): Um indivíduo ou grupo de indivíduos com interesse comum no desempenho de organizações e no ambiente em que opera. A maioria das organizações possui as seguintes partes interessadas: (1) os clientes; (2) a força de trabalho; (3) os acionistas e os proprietários; (4) os fornecedores e (5) a sociedade. A quantidade e a denominação das partes interessadas pode variar em função do perfil da organização (FPNQ 2002).

Perigo: Fonte ou situação com potencial para provocar danos em termos de lesão, doença, dano à propriedade, dano ao meio-ambiente do local do trabalho, ou uma combinação desses (OHSAS 18001).

Plano: Conjunto de medidas que visam a determinado objetivo (HOUAISS 2001).

Política: Série de medidas par a obtenção de um fim ou conjunto de princípios (HOUAISS 2001).

Práticas de Gestão: Atividades executadas regularmente com a finalidade de gerir uma organização de acordo com os padrões de trabalho (FPNQ 2002). 
Proatividade: Capacidade de tomar a iniciativa e autonomia para antecipar-se aos fatos com ações preventivas (FPNQ 2002).

Processo: Conjunto de recursos e atividades inter-relacionadas que transformam insumos (entrada) em produtos (saídas). Essa transformação deve agregar valor na percepção dos clientes do processo e exige um certo conjunto de recursos. Os recursos podem incluir pessoal, finanças, instalações, equipamentos, métodos e técnicas, numa seqüência de etapas ou ações sistemáticas. O processo poderá exigir que a seqüência de etapas seja documentada por meio de especificações, de procedimentos e de instruções de trabalho, bem como que as etapas de medição e controle sejam adequadamente definidas (FPNQ 2002).

Programa: Aquilo que alguém se propõe a executar (HOUAISS 2001).

Projeto: Descrição escrita e detalhada de um empreendimento a ser realizado (HOUAISS 2001).

Requisito: Necessidade ou expectativa que é expressa, geralmente, de forma implícita ou obrigatória (ABNT NBR ISO 9000).

Risco: Combinação da probabilidade e gravidade (conseqüência) de um determinado fator de risco ocorrer (OHSAS 18001).

Saúde e segurança: Condições e fatores que afetam o bem-estar dos funcionários, trabalhadores temporários, pessoal de contratadas, visitantes e quaisquer pessoas presentes no local de trabalho (OHSAS 18001).

Saúde: Estado de equilíbrio dinâmico entre o organismo e seu ambiente, o qual mantém as características estruturais e funcionais do organismo dentro dos limites normais para forma particular de vida (raça, gênero, espécie) e para a fase particular de seu ciclo vital. Estado de boa disposição física e psíquica (HOUAISS 2001). 
Segurança: Isenção de risco de dano inaceitável (OHSAS 18001).

Sistema de Gestão: Sistema para estabelecer política e objetivos e para atingir estes objetivos (ABNT NBR ISO 9000).

Sistema: Conjunto de elementos inter-relacionados ou interativos (ABNT NBR ISO 9000).

Stakeholders: Ver partes interessadas. 